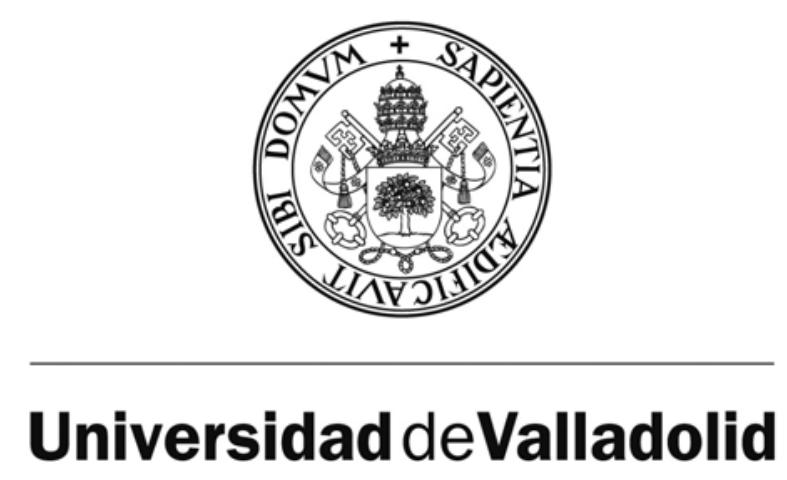

FACULTAD DE CIENCIAS

DEPARTAMENTO DE FISICA DE LA MATERIA CONDENSADA, CRISTALOGRAFÍA Y MINERALOGÍA

TESIS DOCTORAL:

\title{
CELLULAR NANOCOMPOSITES BASED ON RIGID POLYURETHANE AND NANOCLAYS: \\ FABRICATION, CHARACTERIZATION AND MODELING OF THE MECHANICAL AND THERMAL PROPERTIES
}
Presentada por ......SERGIO ESTRAVÍS SASTRE........ para optar al grado de doctor / ra por la Universidad de Valladolid





\section{Financiación}

He de agradecer la financiación para llevar a cabo esta investigación que he recibido de diversas instituciones. En primer lugar las becas para para la realización de la tesis doctoral concedida inicialmente por la Junta de Castilla y León, y finalmente por el Ministerio de Educación (beca FPU (AP2008-03602)). A su vez, la realización de estancias y asistencia a congresos han sido en general financiadas por la beca FPU y la Uva y también por diversos proyectos del grupo de investigación. Además, agradecemos la financiación recibida por el grupo CellMat para el estudio de materiales celulares poliméricos proveniente de los siguientes proyectos:

1. MINISTERIO DE ECONOMIA Y COMPETIVIDAD, Programa Nacional de Materiales. MAT2006-11614-C03-01, MAT 2009-14001-C02-01 y MAT 2012-34901

2. PROYECTO EUROPEO NANCORE "Microcellular nanocomposite for substitution of Balsa wood and PVC core material". VII Programa Marco, EC Project Number 214148,Contract No. NMP3-LA-2008-214841

3. "Desarrollo de nuevas espumas de poliuretano con mejoras en el aislamiento térmico". Financiado por BSH-group 061/111055

4. "Espumas de poliuretano para la fabricación de tablas de surf", Financiado por Foam Asturblank 061/090501

5. "Uso de nanopartículas de sepiolita para la optimización de la estructura y las propiedades de espumas de PS y PU". Financiado por TOLSA S.A 061/121051

Asimismo, agradecemos a Luis Vela, de BASF Poliuretanos Iberia S.A., por el apoyo logístico a la hora de suministrar formulaciones para el desarrollo de esta investigación.

\section{Funding}

Financial assistance during the course of this thesis from UVa, Junta of Castile and Leon, and FPU grant (AP2008-03602) is gratefully acknowledged.

Financial assistance provided by the following research projects is also acknowledged:

1. MINISTRY OF ECONOMY AND COMPETITIVENESS, National Materials Program. MAT2006-11614-C03-01 y MAT 2009-14001-C02-01, y MAT 2012-34901

2. EUROPEAN NANCORE PROJECT "Microcellular nanocomposite for substitution of Balsa wood and PVC core material". VII FrameWork Program, EC Project Number 214148,Contract No. NMP3-LA-2008-214841

3. "Development of novel polyurethane foams with improved thermal insulation". Funded by BSH-group 061/111055

4. "Polyurethane foams for the production of surf boards ", Funded by Foam Asturblank 061/090501

5. "Use of sepiolite nanoparticles to optimize the structure and properties of PS and PU based foams". Funded by TOLSA S.A 061/121051.

We would also like to thank Mr. Luis Vela from BASF for supplying of some of the formulations used in this thesis 



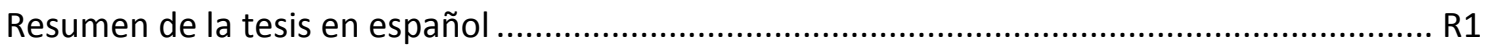

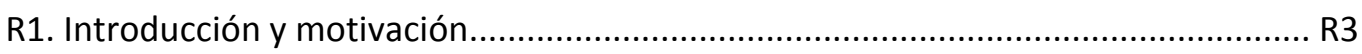

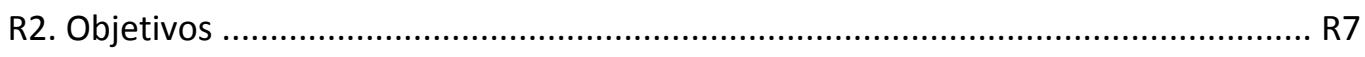

R.3. Materiales, fabricación y técnicas de caracterización empleadas .......................... R9

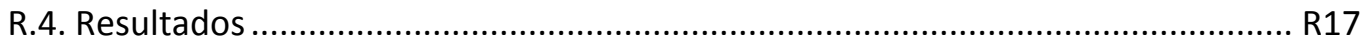

R.5. Conclusiones y trabajo futuro …………………......................................... R22

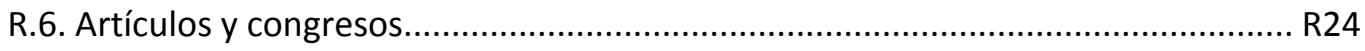

R.7. Aplicación de los resultados obtenidos en procesos industriales......................... R26

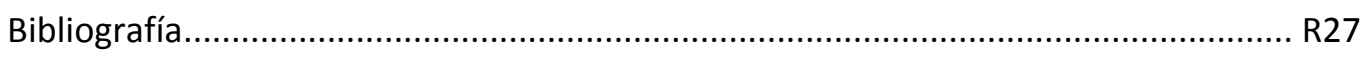

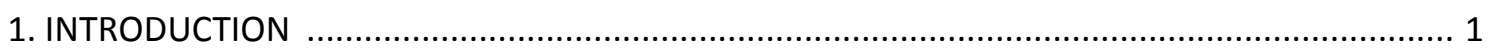

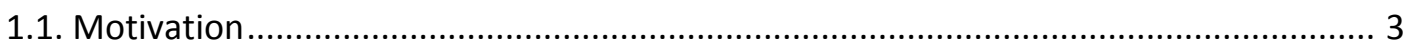

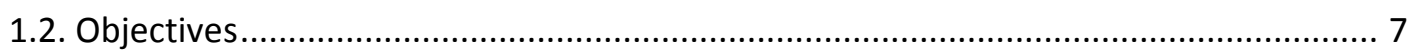

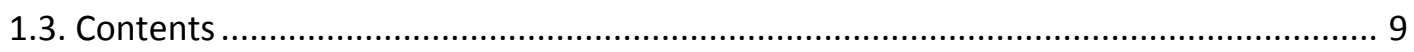

1.4. Publications and presentations in conferences ................................................. 10

1.5. Applicability of the obtained results in industrial processes .................................... 11

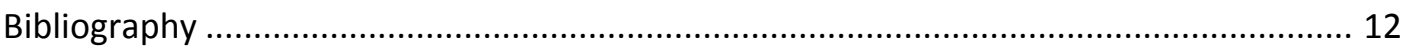

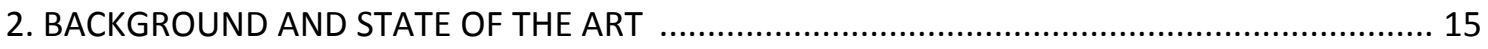

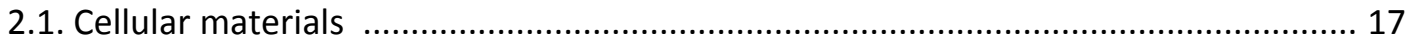

2.1.1. Description, advantages and types ……........................................................ 20

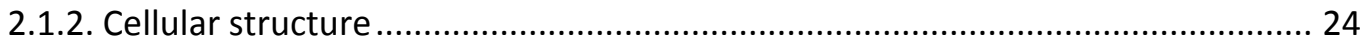

2.1.3. Estimation of mechanical properties of cellular materials ................................. 25 
Index

2.1.4. Thermal conductivity of cellular materials ................................................ 25

2.2. Water Blown Rigid Polyurethane Foams ......................................................... 27

2.2.1. Chemistry of polyurethane .............................................................. 27

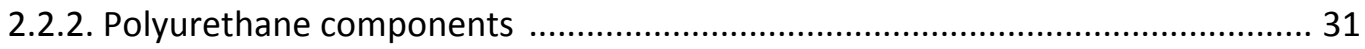

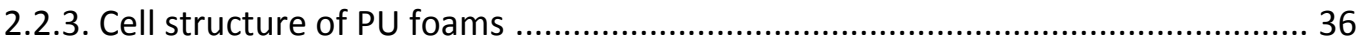

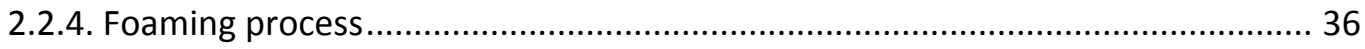

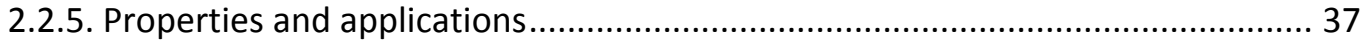

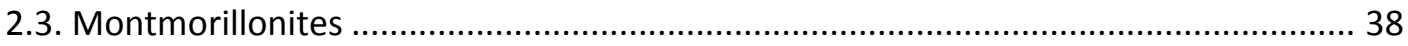

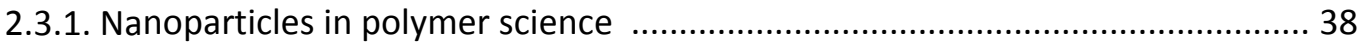

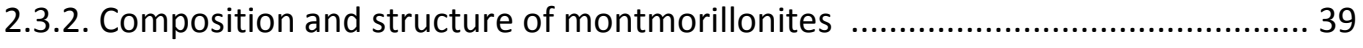

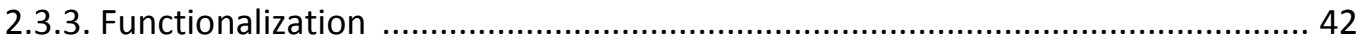

2.4. Foamed polyurethane nanocomposite filled with nanoclays: state of the art.......... 45

2.4.1. Density and Foaming Agents ............................................................ 45

\subsubsection{Dispersion Techniques used to}

produce the polyurethane nanocomposite foams............................................. 48

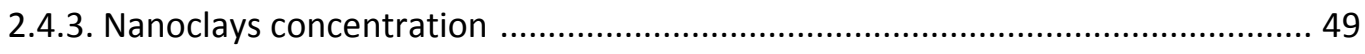

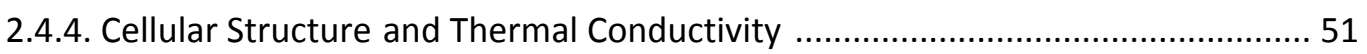

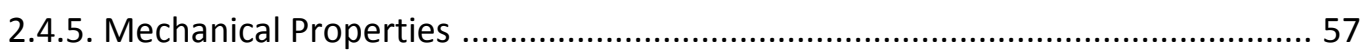

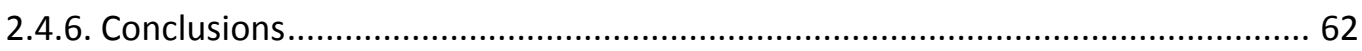

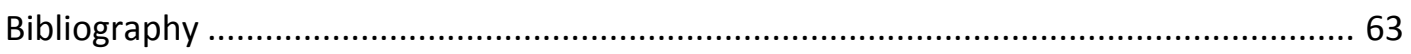

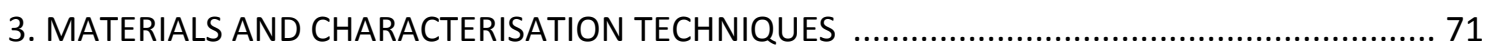

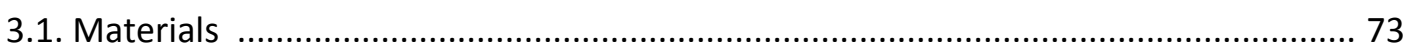

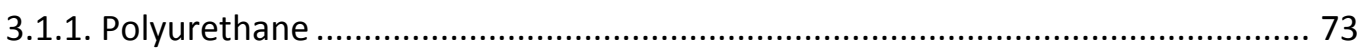

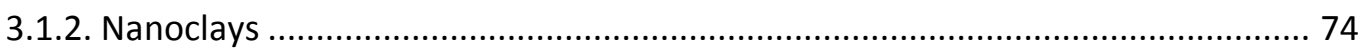

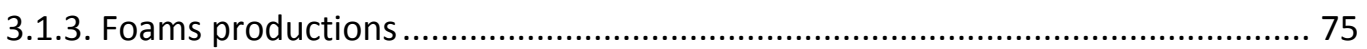

3.1.4. Samples preparation ........................................................................ 80 


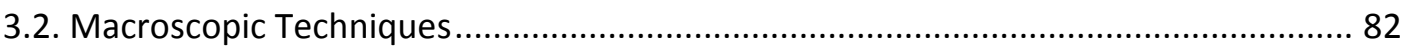

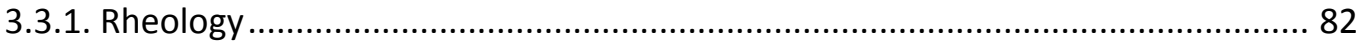

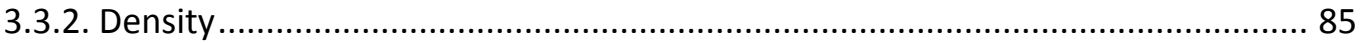

3.3.3. Mechanical properties at low strain rates: compression, bending and

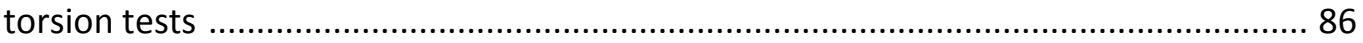

3.3.4. Dynamic Mechanical Analysis (DMA) ................................................................ 90

3.3.5. Thermal conductivity ......................................................................................... 91

3.3.5.1. Rapid K Heat Flow Meter ................................................................ 92

3.3.5.2. Transient Plane Source .................................................................... 93

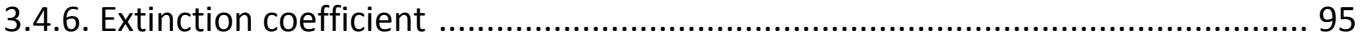

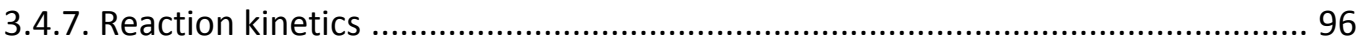

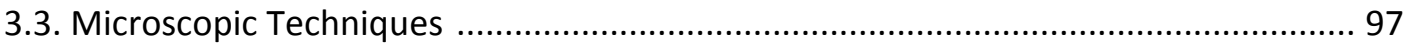

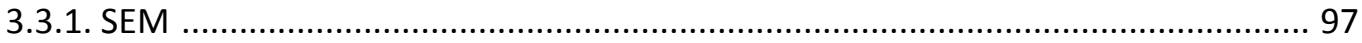

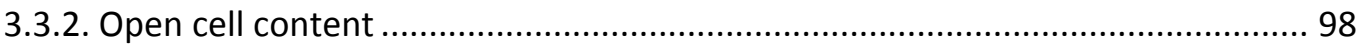

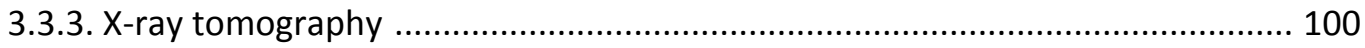

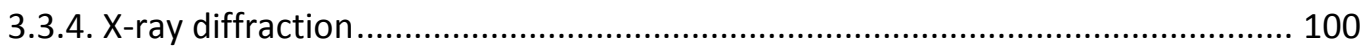

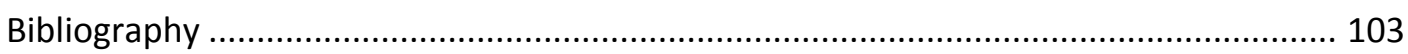

4. INFLUENCE OF THE FORMULATION AND DISPERSION TECHNIQUE EMPLOYED .................... 105

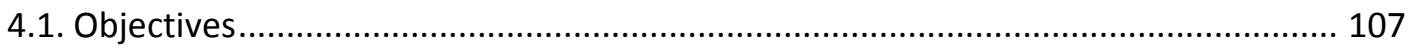

4.2. Rheological study for the different dispersion techniques

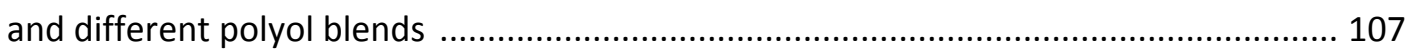

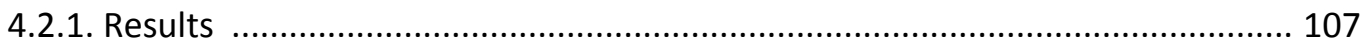

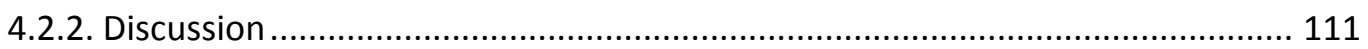

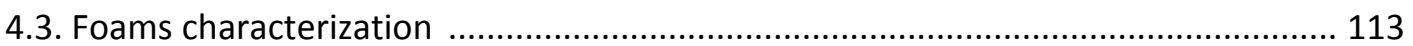

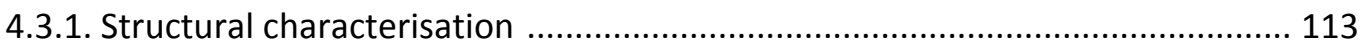

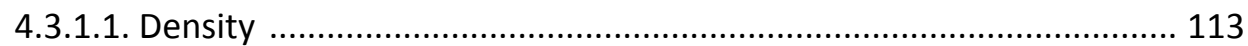


Index

4.3.1.2 Cellular structure 114

4.3.1.3 SAXS 118

4.3.2. Macroscopic characterisation 120

4.3.2.1. Dynamic Mechanical Analysis ........................................................ 120

4.3.2.2. Mechanical properties in compression and shear ........................... 122

4.3.2.3. Mechanical properties in compression: Comparison

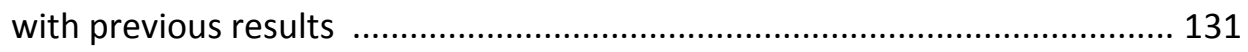

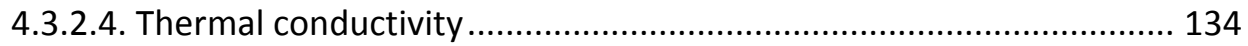

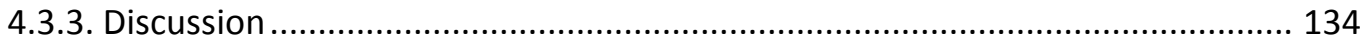

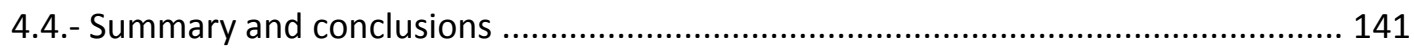

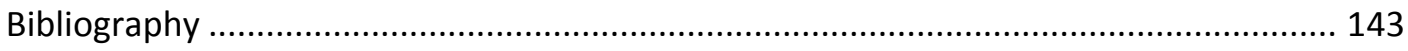

5. NANOCLAYS CONCENTRATION: EFFECTS ON MECHANICAL PROPERTIES AND THERMAL

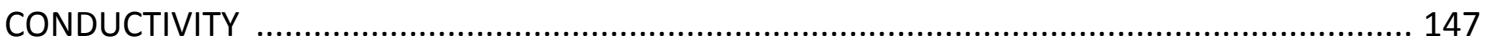

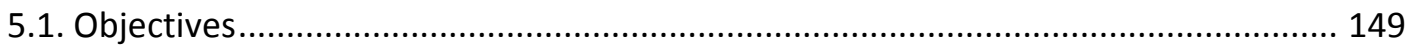

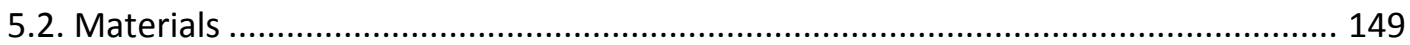

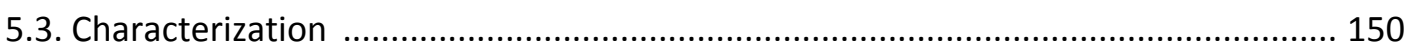

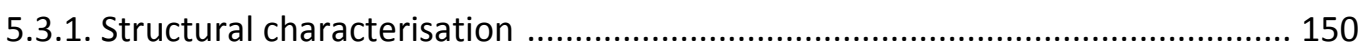

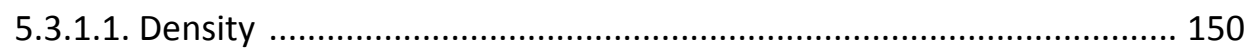

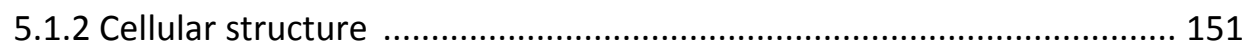

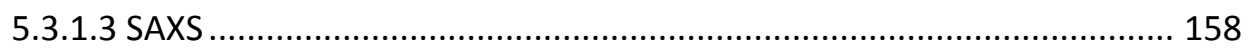

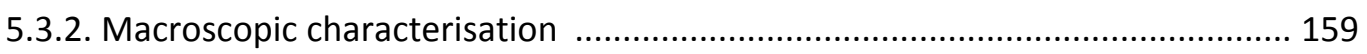

5.3.2.1. Mechanical properties: compression, bending and shear ................ 159

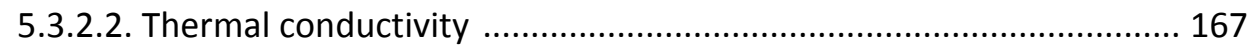

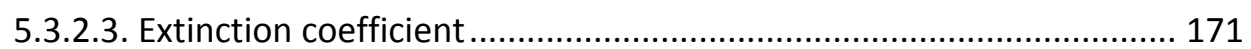

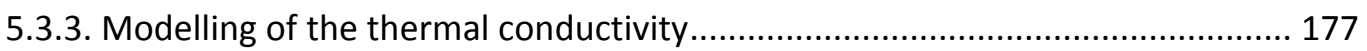

5.3.2.2. Modelling the Extinction Coefficient ................................................ 177 
Index

5.3.2.3. Prediction of Thermal Conductivity ................................................ 179

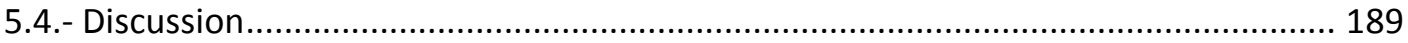

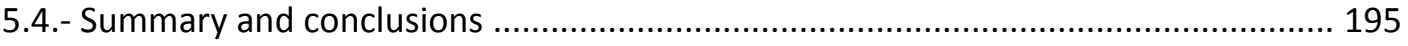

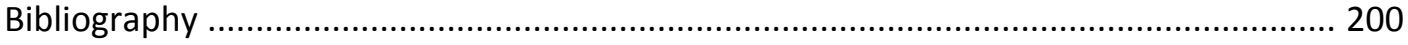

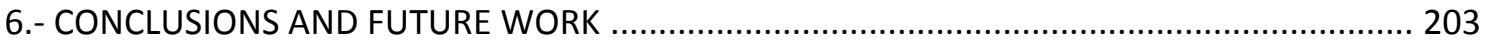



RESUMEN DE LA TESIS EN ESPAÑOL 



\section{Resumen de la tesis en español}

\section{R.1. Introducción y motivación}

Una de las principales motivaciones para la realización del presente trabajo de investigación fue la creación de una nueva línea de investigación en espumas de poliuretano en el Laboratorio CellMat, perteneciente al Departamento de Física de la Materia Condensada, Cristalografía y Mineralogía de la Universidad de Valladolid. CellMat fue creado en 1999 por los Catedráticos José Antonio de Saja y Miguel Ángel Rodríguez Pérez, con el objetivo de estudiar los materiales celulares. Desde entonces numerosos temas han sido tratados dentro de CellMat, como el desarrollo de nuevas rutas de producción para materiales celulares, la obtención de productos multifuncionales más ligeros y con propiedades mejoradas, creación de nuevos conocimientos dentro de la relación procesado-estructura-propiedadesaplicaciones, modelado del comportamiento físico de los materiales celulares, etc.

La producción científica de CellMat ${ }^{1-13}$ ha estado centrada principalmente en las espumas termoplásticas y de aluminio, y dentro de los termoplásticos particularmente en los materiales basados en poliolefinas. Pese a ello, la presencia en el mercado de estos materiales era, y continúa siendo, muy pequeña frente a materiales celulares como el poliuretano (PU), el poliestireno (PS) y el policloruro de vinilo (PVC). Esta fue una de las principales razones que animo a la creación de una nueva línea de investigación centrada en el área de las espumas de poliuretano.

Las espumas de poliuretano presentan un amplio rango de aplicaciones en diferentes industrias como la de automoción, equipamiento deportivo, muebles y construcción, entre muchas otras. Sólo en los Estados Unidos, el negocio del poliuretano tiene un mercado estimado de 20.000 millones de dólares y es un elemento fundamental en la economía norteamericana, empleando de manera directa a más de 200.000 personas $^{14}$. A nivel mundial, la estimación total del mercado del poliuretano es de unos 40.000 millones de dólares, esperándose que crezca hasta alcanzar los 62.000 millones en $2018^{15}$. En el origen de esta gran presencia en el mercado se encuentra el gran potencial de aplicación de este tipo de espumas, que permite adaptarlas prácticamente a cualquier situación sin más que cambiar los componentes iniciales. Junto con esto, la "aparente sencillez" de la tecnología de espumado ha hecho a estos materiales muy competitivos desde el punto de vista económico. 
En la actualidad hay que añadir a todo esto el creciente mercado de la nanotecnología, la cual ha tenido un considerable impacto sobre las investigaciones que se han llevado a cabo en CellMat en los últimos años. En general, las nanopartículas pueden tener un impacto significativo sobre los materiales, y en particular sobre el mundo de las espumas de poliuretano, abriendo un amplio abanico para modificar las propiedades a la carta. El empleo de nanopartículas en la investigación científica ha presentado un aumento significativo en los últimos años ${ }^{16-19}$, e incluso muchas de las ventajas del empleo de esta tecnología han alcanzado ya el mercado ${ }^{20,21}$. Su presencia como aditivo en materiales convencionales puede suponer, además del refuerzo de determinadas propiedades ya existentes, la aparición de otras nuevas ${ }^{22}$. De entre todos los nanomateriales empleados para la fabricación de nanocompuestos poliméricos, las nanoarcillas son uno de los más estudiados ${ }^{12}{ }^{23-25}$. El secreto de este éxito se encuentra en que las nanoarcillas son materiales presentes en la naturaleza que ya están siendo comercializados, presentando una morfología laminar con considerable relación de aspecto y grandes capacidades de intercambio de cationes.

Por todas las razones previamente expuestas, las espumas de poliuretano reforzadas con nanoarcillas es un tema muy actual dentro de la investigación en materiales, con un alto potencial de aplicación, lo que explica el interés suscitado dentro de CellMat. Varios trabajos han sido ya publicados en este tema previamente, por ejemplo Modesti et al. ${ }^{22}$ estudiaron las posibles sinergias en el retardo de llama entre los ignifugantes basados en fosforo (fosfinatos de aluminio) y silicatos multicapa usando como matriz polimérica espumas de poliuretano, obteniendo que las arcillas actuaban como barrera física previniendo o disminuyendo la difusión de volátiles u oxígeno. El procesado, estructura y propiedades de nanocompuestos de espumas (tanto rígidas como flexibles) de poliuretano basados en arcillas ha sido estudiado por Cao et al. ${ }^{26}$, observándose un aumento en la densidad celular, una reducción del tamaño de celda respecto al material sin nanopartículas y una reducción de la temperatura de transición vítrea y de las propiedades mecánicas para espumas rígidas. Widya y Macosko ${ }^{27}$ incorporaron mediante ultrasonicación diferentes concentraciones de nanoarcillas $(1,2,3$ y 5 $\%)$ en espumas rígidas de poliuretano, obteniendo una reducción del tamaño de celda y un aumento de la densidad celular incluso para los contenidos más bajos de nanoarcillas.

El presente trabajo explora el efecto de la incorporación de nanoarcillas en la estructura celular, en las propiedades mecánicas y en las térmicas de espumas rígidas de poliuretano de una manera distinta a la que se ha venido haciendo en la literatura previa. Aunque anteriormente se había estudiado la incorporación de nanoarcillas en espumas de poliuretano rígidas, se echaba en falta un mayor detalle en el estudio de aspectos tales como $\mathrm{R} \mid 4$ 
la calidad de la dispersión de las arcillas, el grado de la exfoliación de las nanopartículas, la influencia de éstas en la estructura celular, en el estudio de los mecanismo físicos y químicos que podrían afectar a las propiedades físicas y modelado de las propiedades. Los trabajos publicados previamente han estado típicamente centrados en un amplio número de partículas nanométricas, incluso en un amplio número de formulaciones de poliuretano, lo que ha implicado un estudio menos detallado de cada sistema en particular. En algunos de estos estudios, parámetros claves en los materiales celulares como la densidad o la estructura celular no han sido estudiados en detalle. De manera general, aspectos como la dispersión y exfoliación de las nanopartículas y el modelado de las propiedades no se han estudiado a fondo. Por estas razones, en este trabajo hemos seleccionado un número limitado de formulaciones y un tipo particular de nanoarcillas funcionalizadas con el objetivo de llevar a cabo un estudio más detallado de estos sistemas particulares. Con todos los datos obtenidos de la caracterización y mediante el empleo de diferentes modelos teóricos, se han identificado los orígenes de los cambios en las propiedades finales, permitiendo estos resultados analizar la influencia de los diferentes parámetros que han sido modificados por la aditivación de las nanoarcillas.

Otro aspecto que debe tenerse en cuenta para comprender el desarrollo de la presente tesis es la participación de CellMat en el proyecto europeo titulado: "NanCore: nancompuestos microcelulares para la sustitución de la madera de balsa y el PVC", perteneciente al Séptimo Programa Marco de la Unión Europea y que se desarrolló entre Noviembre de 2008 y Octubre de 2012. El principal objetivo del citado proyecto era el diseño de un nuevo nancompuesto de bajo coste y estructura microcelular, cuyas propiedades mecánicas fuesen comparables o incluso superiores a las de la madera de Balsa y a las de la espuma de PVC, siendo por tanto capaces de sustituir a estos materiales como núcleo de estructuras sándwich de bajo peso. En la actualidad, los materiales que se pretendían sustituir están ampliamente presentes en aplicaciones de tipo energético (palas de aerogeneradores) o de transporte (embarcaciones de recreo), con un mercado estimado de unos 2 billones de Euros para los mercados europeos y americano. Además del objetivo referente a la reducción de costes, el desarrollo de este nuevo material podría ayudar a resolver importantes problemas de los consumidores europeos en el mercado y suministro tanto de la espuma de PVC como de la madera de balsa. Respecto a la reducción de costes, el material desarrollado debería presentar una reducción en su coste total de alrededor del 30\% frente a los materiales a los cuales pretendía sustituir, de los cuales la madera de balsa es el más barato. Por otro 
Resumen de la tesis en Español

lado, el material desarrollado debería presentar unas propiedades mecánicas que permitiesen su aplicación en la industria eólica, como primer objetivo demandado desde la industria.

TABLA R.1. Participantes y principals actividades del proyecto NanCore.

\begin{tabular}{|c|c|c|}
\hline $\begin{array}{l}\text { Nombre del } \\
\text { participante }\end{array}$ & País & Principales actividades \\
\hline $\begin{array}{l}\text { LM Glasfiber } \\
\qquad \mathrm{A} / \mathrm{S} \\
\text { (Cordinador) }\end{array}$ & Dinamarca & $\begin{array}{c}\text { Especificación de los requisitos referentes al procesado, producción, y } \\
\text { características mecánicas. Demostración y pruebas a gran escala. } \\
\text { Gestión del Consorcio. Integración de nanocompuesto polimérico } \\
\text { microcelular (MNPC) en la estructura sándwich }\end{array}$ \\
\hline $\begin{array}{l}\text { Aalborg } \\
\text { University }\end{array}$ & Dinamarca & $\begin{array}{l}\text { Modelado multi-escala y simulaciones de los nanocompuestos } \\
\text { microcelulares; integración de MNPC en la estructura de sándwich; } \\
\text { selección de componentes funcionalizados para los nanocompuestos. }\end{array}$ \\
\hline $\begin{array}{l}\text { Recticel } \\
\text { Polyurethanes }\end{array}$ & Bélgica & $\begin{array}{l}\text { Desarrollo de formulaciones de poliuretano. Fabricación de espumas de } \\
\text { poliuretano a escala industrial. }\end{array}$ \\
\hline $\begin{array}{l}\text { Katholieke } \\
\text { Universiteit } \\
\text { Leuven }\end{array}$ & Bélgica & $\begin{array}{c}\text { Caracterización reológica de los nanocompuestos, modelado multi- } \\
\text { escala y simulaciones de los nanocompuestos, integración de } \\
\text { nancompuesto polimérico microcelular (MNPC) en la estructura } \\
\text { sándwich. }\end{array}$ \\
\hline $\begin{array}{l}\text { Universität } \\
\text { Kassel }\end{array}$ & Alemania & $\begin{array}{l}\text { Procesado industrial del nanocomposite microcelular, caracterización } \\
\text { mecánica de los paneles sandwich de espumas. }\end{array}$ \\
\hline $\begin{array}{l}\text { University of } \\
\text { Valladolid }\end{array}$ & España & $\begin{array}{c}\text { Producción y caracterización de las espumas a escala laboratorio, } \\
\text { análisis de los mecanismos de espumación. }\end{array}$ \\
\hline $\begin{array}{l}\text { Azimut-Benetti } \\
\text { S.P.A. }\end{array}$ & Italia & $\begin{array}{c}\text { Especificación de los requisitos con respecto al procesado; integración } \\
\text { del MNPC en la estructura sándwich, demostración y pruebas a gran } \\
\text { escala. }\end{array}$ \\
\hline $\begin{array}{l}\text { Centre of } \\
\text { Molecular and } \\
\text { Macromolecular } \\
\text { Studies }\end{array}$ & Polonia & $\begin{array}{l}\text { Selección de componentes funcionalizados para los nanocompuestos y } \\
\text { de los elementos del proceso de espumado, producción y } \\
\text { caracterización de nanocompuestos sólidos de PP para aplicaciones de } \\
\text { espumación. }\end{array}$ \\
\hline
\end{tabular}

\begin{tabular}{c|c|c}
$\begin{array}{c}\text { Institute of } \\
\text { Occupational }\end{array}$ & $\begin{array}{c}\text { Reino } \\
\text { Unido }\end{array}$ & $\begin{array}{c}\text { Asuntos referentes a la seguridad de las nanopartículas empleadas en } \\
\text { los nanocomposites }\end{array}$ \\
\hline
\end{tabular}

Technical

University of Dinamarca Análisis del ciclo de vida del nuevo material

Denmark

\begin{tabular}{|c|c|c|}
\hline EconCore N.V. & Bélgica & Integración del MNPC en la estructura sándwich. \\
\hline FOCAL Limited & $\begin{array}{l}\text { Reino } \\
\text { Unido }\end{array}$ & $\begin{array}{c}\text { Especificación de los requisitos con respecto al procesado; integración } \\
\text { del MNPC en la estructura sándwich; demostración y pruebas a gran } \\
\text { escala }\end{array}$ \\
\hline
\end{tabular}

\begin{tabular}{c|c|c}
$\begin{array}{c}\text { Sekisui Alveo } \\
\text { AG }\end{array}$ & Suiza & Producción del nanocompuesto de PP espumado a escala industrial.
\end{tabular}


El consorcio para este proyecto consistía en una combinación de empresas líderes que usarían este tipo de compuestos, junto con una serie de grupos de investigación expertos en materiales (Ver tabla R.1). Durante este proyecto CellMat lideró el Paquete de Trabajo 3 (WP3): "Espumado de nanocompuestos". Una parte importante de la actividad investigadora estuvo centrada en la mejora de formulaciones de poliuretano suministradas por el socio industrial del proyecto Recticel mediante la incorporación de nanoarcillas. Junto con esto, una parte de la investigación, en aspectos relacionados con la calidad de la dispersión de las nanopartículas, fue llevada a cabo en colaboración con la Universidad Católica de Lovaina (KUL), integrante también del consorcio del proyecto.

\section{R.2. Objetivos}

Dado que este trabajo ha sido el primer contacto del grupo CellMat con las espumas de poliuretano, los objetivos de la presente tesis no se restringen simplemente a los sistemas de poliuretano y nanoarcillas bajo estudio, sino que se encuentran también relacionados con poner a punto una serie de técnicas de fabricación y caracterización necesarias en el estudio de estos materiales y que puedan ser útiles para futuros proyectos de investigación. Debido a esto, los objetivos de esta tesis se pueden dividir en Objetivos Metodológicos y Objetivos Científicos.

\section{Objetivos Metodológicos:}

- Puesta a punto del proceso de producción de espumas rígidas de poliuretano con nanopartículas: el objetivo era establecer un procedimiento estándar con el fin de obtener una elevada reproducibilidad en la producción de muestras, eliminando así cualquier posible cambio debido a variables no controladas. Este procedimiento mostró su validez tanto para espumas reforzadas con nanopartículas como sin reforzar, asegurando una buena estructura celular y buenas propiedades físicas. Para llevar a cabo este objetivo varios subobjetivos se tuvieron que llevar a cabo:

Selección de las formulaciones de poliuretano rígido.

Selección de las nanopartículas

$>$ Optimización del proceso de dispersión de las nanopartículas

> Optimización de los parámetros de procesado para la producción de espumas. 
Tabla R.2.- Técnicas de caracterización empleadas

\begin{tabular}{|c|c|c|}
\hline $\begin{array}{l}\text { Técnica de caracterización / propiedad } \\
\text { medida }\end{array}$ & Equipo & Método \\
\hline Medida de densidad & Mettler Toledo AT261 & ASTM D1622 28 \\
\hline $\begin{array}{l}\text { Propiedades mecánicas: ensayos a } \\
\text { compresión }\end{array}$ & $\begin{array}{l}\text { Máquina de ensayos universal } \\
\text { Instron, modelo 5500R6025 }\end{array}$ & ASTM D $1621^{29}$ \\
\hline $\begin{array}{l}\text { Propiedades mecánicas: ensayos a } \\
\text { flexión }\end{array}$ & $\begin{array}{l}\text { Máquina de ensayos universal } \\
\text { Instron, modelo 5500R6025 }\end{array}$ & ISO $178: 2010^{30}$ \\
\hline $\begin{array}{c}\text { Propiedades mecánicas: ensayos a } \\
\text { torsión }\end{array}$ & $\begin{array}{c}\text { TA-instrument, reómetro Ares- } \\
\text { melts }\end{array}$ & - \\
\hline Análisis dinamo-mecánico (DMA) & Mettler Toledo DMA/SDTA 861e & - \\
\hline Conductividad térmica & $\begin{array}{c}\text { Holometrix Rapid K Heat Flow } \\
\text { Meter }\end{array}$ & UNE12667 ${ }^{31}$ \\
\hline Conductividad térmica & $\begin{array}{l}\text { Plato caliente de fuente plana } \\
\text { transitoria para la medida de la } \\
\text { constante térmica (TPS) }\end{array}$ & ISO $22007-2: 2008^{32}$ \\
\hline
\end{tabular}

Espectroscopia infrarroja para determinar la cinética de las reacciones y el coeficiente de extinción
Espectrómetro Bruker Tensor 27 FTIR

Microscopía electrónica de barrido (SEM)

JEOL JSM 820

Picnometría para determinar el contenido de celda abierta
Eijkelcamp 08.06 Langer
ASTM D6226 33

Tubo de rayos-X FXE- 160.50,

fuente de Feinfocus, sistema de

Tomografía de rayos $\mathrm{X}$ detección PerkinEImer XRD 1620

CN3, etapa rotativa de MICOS

(UPR-160F AIR)

Reología para el análisis de la dispersión de las nanoarcillas

ARES-G2, TA Instruments

Difracción de rayos $\mathrm{X}$ a ángulos bajos para determinar el grado de exfoliación
Bruker Discover D8 equipado con un detector LynxEye

- Optimización de las técnicas de caracterización de espumas de poliuretano. Diferentes técnicas de caracterización previamente empleadas en CellMat para otro tipo de espumas (principalmente flexibles) han sido adaptadas para la caracterización de las espumas rígidas de poliuretano. En la tabla 1.2 se presentan estas técnicas de caracterización junto con las correspondientes 
normas que se han seguido (en caso de existir). Todas estas técnicas han sido adaptadas en mayor o menor medida. En particular las técnicas que han requerido un mayor esfuerzo a la hora de su adaptación han sido las empleadas para el estudio del grado de dispersión (mediante reología) y para la medida del coeficiente de extinción mediante espectroscopía infrarroja.

Objetivos Científicos: Se ha pretendido realizar un estudio detallado de los sistemas bajo estudio.

- Evaluar en detalle el efecto de la calidad de las dispersiones de las nanoarcillas en el poliol sobre la estructura y propiedades de las espumas de poliuretano reforzadas con nanoarcillas.

- Evaluar en detalle el efecto del contenido de nanoarcillas en la estructura celular, en las propiedades mecánicas y en las propiedades térmicas de los nanocompuestos de espuma de poliuretano.

- Mejorar las propiedades térmicas en conductividad térmica empleando las nanoarcillas como agentes nucleantes y bloqueantes de la radiación infrarroja.

- Modelar la conductividad térmica de las espumas fabricadas, empleando para ello la caracterización en detalle de la estructura celular y la medida del coeficiente de extinción de las espumas.

\section{R.3. Materiales, fabricación y técnicas de caracterización empleadas}

A continuación se procede a describir los materiales y las técnicas de caracterización empleadas en el desarrollo de esta tesis.

\section{Materiales:}

Tres formulaciones diferentes de poliuretano rígido, suministradas por BASF (1 formulación) y Recticel (2 formulaciones), fueron empleadas en el desarrollo de esta tesis. La selección de estos materiales estuvo condicionada por los requerimientos del proyecto NanCore, que hacían necesaria la utilización de espumas de baja densidad y buenas propiedades mecánicas de partida (rigidez y resistencia). En la tabla R.3 se describen las principales propiedades de las formulaciones. 
La formulación proporcionada por BASF se trataba de una formulación comercial, mientras que las proporcionadas por Recticel estaban diseñadas específicamente para este proyecto, dado que Recticel pertenecía al consorcio del proyecto NanCore. La densidad nominal de la espuma de BASF en espumación libre es de $52 \mathrm{~kg} / \mathrm{m}^{3}$, mientras que los materiales de Recticel presentan densidades de 50 y $120 \mathrm{~kg} / \mathrm{m}^{3}$. Un aspecto fundamental a la hora de seleccionar las formulaciones fue la viscosidad del poliol de las mismas, con tres valores diferentes claramente diferenciados.

Todas las formulaciones presentan un isocianato de tipo metil difenil isocianato (MDI), y el agente espumante empleado es agua en todos los casos. En la tabla R.3 se muestra también el nombre abreviado que se ha empleado a lo largo de este trabajo. También se muestra en esta tabla la viscosidad del poliol, que se encuentra entre los 650 y los 100.000 $\mathrm{mPA} \cdot \mathrm{s}$, un amplio rango que permite observar una gran variedad de comportamientos en función de la técnica de dispersión empleada.

Tabla R.3. Principales características de las diferentes formulaciones de poliuretano empleadas en esta investigación

\begin{tabular}{|c|c|c|c|c|c|c|}
\hline & Nombre comercial & $\begin{array}{l}\text { Densidad } \\
\text { nominal en } \\
\text { espumado } \\
\text { libre }\left(\mathrm{Kg} / \mathrm{m}^{3}\right)\end{array}$ & $\begin{array}{l}\text { Relación } \\
\text { Pol./ Iso. } \\
\text { (en peso) }\end{array}$ & $\begin{array}{c}\text { Viscosidad } \\
\text { del poliol } \\
\text { (mPA.s) }\end{array}$ & $\begin{array}{l}\text { Tipo de } \\
\text { poliol }\end{array}$ & $\begin{array}{c}\text { Tipo de } \\
\text { isocianato }\end{array}$ \\
\hline BASF (LV) & $\begin{array}{l}\text { Poliol: Elastopor* H } \\
1501 / 2 \\
\text { Isocianato: IsoPMDI } \\
92140\end{array}$ & 52 & $100 / 160$ & 650 & $\begin{array}{l}\text { Poli- } \\
\text { eter } \\
\text { poliol }\end{array}$ & MDI \\
\hline $\begin{array}{l}\text { Recticel baja } \\
\text { viscosidad } \\
\text { (MV) }\end{array}$ & - & 120 & $100 / 74$ & 1000 & - & MDI \\
\hline $\begin{array}{l}\text { Recticel alta } \\
\text { viscosidad } \\
\text { (HV) }\end{array}$ & - & 50 & 100/196 & 100000 & - & MDI \\
\hline
\end{tabular}

En este estudio se emplearon las nanoarcilas Cloisite 30b, de la empresa Southern Clay Products. Este tipo de nanoarcillas se usan habitualmente para la mejora de varias propiedades físicas en polímeros, tales como rigidez, resistencia, temperatura de distorsión 
térmica, coeficiente lineal de expansión térmica y propiedades barrera. En la tabla R.4 se muestran sus principales características.

Estas nanoarcillas fueron seleccionadas por dos motivos: las recomendaciones del fabricante y su empleo previo en numerosos artículos de la literatura científica ${ }^{22,26,27,34}$ del poliuretano, donde se ha documentado el efecto de este tipo de material sobre propiedades como la estructura celular o la conductividad térmica.

Tabla R.4. Principales características de las nanoarcillas Cloisite 30B empleadas en esta investigación.

\begin{tabular}{|c|c|}
\hline Humedad & $<3 \%$ \\
Tamaño típico de particular & $<10 \mu \mathrm{m}\left(\mathrm{d}_{50}\right)$ \\
seca & Off White \\
Color & $365 \mathrm{~g} / \mathrm{l}$ \\
\hline Densidad Compactas & $1.98 \mathrm{~g} / \mathrm{cm}^{3}$ \\
\hline Densidad & \\
\hline $\begin{array}{c}\text { Resultados en Rayos-X } \\
\text { (espaciado interlamelar) }\end{array}$ & $\mathrm{d}_{001}=1.85 \mathrm{~nm}$ \\
\hline
\end{tabular}

\section{Fabricación}

Para la fabricación de las espumas se empleó el espumado reactivo, consecuencia de la reacción que se produce al mezclar los dos productos reactivos (poliol e isocianato) que dan lugar a la espuma de poliuretano. Previamente al mezclado de estos reactivos se ha de proceder a un premezclado del poliol, con el fin de asegurar la homogeneidad de los diferentes aditivos que éste incluye. La temperatura de los reactivos ha de ser asimismo controlada, a fin de conseguir una mayor reproducibilidad. En el mezclado del poliol y el isocianto se empleó la mezcladora IKA Eurostar Power control-visc P1 (ver Fig. R1), equipada junto con un disco de mezclado Lenart. En la producción de espumas de poliuretano a partir de la formulación de BASF, el poliol y el isocianato fueron mezclados a $1200 \mathrm{rpm}$ durante 15 segundos en un recipiente plástico. Inmediatamente después se transvasó la mezcla a un molde de papel en el cual la reacción de polimerización y el espumado se completaron. 


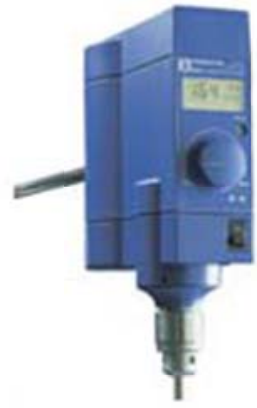

(a)

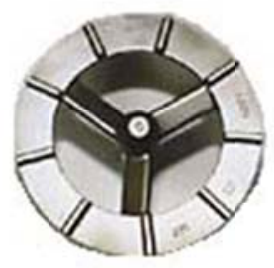

(b)

Figura R.3.- Mezcladora (a) y cabezal de mezclado (b)

Para la producción de espumas de poliuretano reforzadas con nanoarcillas se realizó una etapa adicional: la dispersión de las nanoarcillas en uno de los dos reactivos, concretamente en el poliol por su baja reactividad. Previamente a este paso, las nanoarcillas fueron desecadas en un horno de vacío en torno a $60^{\circ} \mathrm{C}$ de temperatura durante varias horas, con el fin de evitar posibles reacciones entre el isocianato y el agua que afecten a las cinéticas de espumado y a la densidad final.

TABLA R.5. Principales características de las diferentes técnicas de dispersión utilizadas.

\begin{tabular}{|c|c|c|c|c|}
\hline Técnica de dispersión & $\begin{array}{c}\text { Herramienta de } \\
\text { mezclado }\end{array}$ & $\begin{array}{l}\text { Tiempo de } \\
\text { mezclado(s) }\end{array}$ & $\begin{array}{c}\text { Velocidad de } \\
\text { mezclado (rpm) }\end{array}$ & Otras características \\
\hline $\begin{array}{l}\text { Mezclado a mano } \\
\text { (HM) }\end{array}$ & Paleta & $\sim 30$ & 30 & - \\
\hline
\end{tabular}

\begin{tabular}{|c|c|c|c|c|}
\hline $\begin{array}{l}\text { Mezclado de baja } \\
\text { cizalla (LS) }\end{array}$ & $\begin{array}{c}\text { IKA Eurostar Power } \\
\text { control-visc P1, } \\
\text { equipada con una } \\
\text { cabeza mezcladora de } 4 \\
\text { hojas }\end{array}$ & 120 & 200 & - \\
\hline Ultra-sonicación (US) & $\begin{array}{l}\text { Sonics Vibra-Cell VCX } \\
750 \text { (Fig. 3.1.e), } 20 \mathrm{KHz} \text {, } \\
\text { ciclos de } 3 \text { segundos de } \\
\text { sonicación con } 2 \\
\text { segundos de parada } \\
\text { entre ciclos }\end{array}$ & 1500 & - & $\begin{array}{c}\text { Premezclado a mano } \\
\text { de las nanoarcillas } \\
\text { previo a la sonicación }\end{array}$ \\
\hline
\end{tabular}


Las diferentes técnicas de mezclado se resumen en la tabla R.5, mientras que en la Figura R.2 se indican los diferentes pasos llevados a cabo en la fabricación de los nanocompuestos: pesado de la cantidad justa de nanoarcillas a emplear (1), añadir la cantidad estipulada de poliol (1), dispersión de las nanoarcillas con la técnica elegida (2), incorporación de la cantidad necesaria de isocianato (3), mezclado de la dispersión de nanoarcillas en poliol junto con el isocianato (4) para a continuación verter esta mezcla en un molde de papel (5). Las dimensiones del molde empleado en este último paso variaron entre los $110 \times 110 \times 80 \mathrm{~mm}^{3}$ en el caso de las muestras fabricadas para el estudio de la dispersión, y los $310 \times 250 \times 60 \mathrm{~mm}^{3}$ para el estudio del efecto de la concentración. Estas variaciones se debieron a las diferentes dimensiones de los materiales necesarios para realizar los estudios de caracterización.

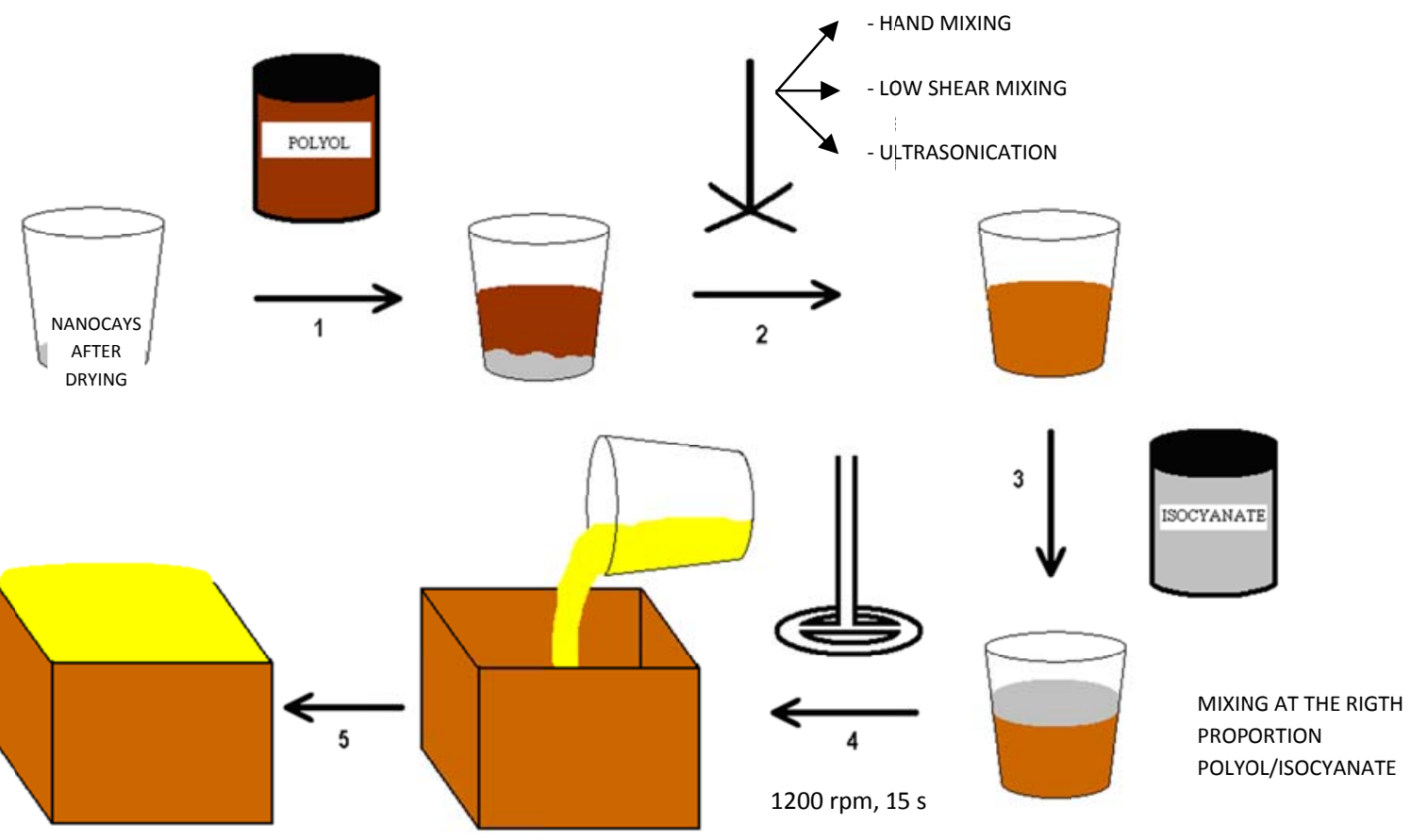

Figura R.2. Esquema de fabricación de los nanocompuestos celulares

Para la caracterización de las muestras se procedió a eliminar la parte más exterior de las espumas con el fin de conseguir un valor de densidad y propiedades constantes sobre toda la muestra analizada.

\section{Caracterización Macroscópica}

A continuación se detallan y describen brevemente las diferentes técnicas de caracterización macroscópicas empleadas:

Reología: La reología (Reómetro ARES-G2 de TA Instruments) ha sido empleada de manera cualitativa para el estudio de la calidad de la dispersión 
de las nanoparticulas en el poliol, previo a la fabricación de las espumas. Para ello se han empleado las 3 formulaciones previamente descritas, y en cada una de ellas han sido dispersadas las nanopartículas. En este análisis ha sido fundamental la representación de Winter ${ }^{35}$, del módulo de la viscosidad compleja $\left|\eta^{*}\right|$ frente al módulo complejo de cizalla $\left|G^{*}\right|$. En esta representación es posible comparar diferentes técnicas de dispersión para una concentración dada de nanopartículas e identificar la técnica que mejor actúa como aquella que produce un mayor cambio frente al material puro.

Densidad: Las medidas de densidad fueron realizadas de acuerdo con la norma ASTM D $1622^{28}$, calculándose la densidad como el cociente de la masa y el volumen. Las muestras fueron acondicionadas a una temperatura de $21 \pm 2 \stackrel{\circ}{\circ}$ y con una humedad relativa del $50 \%$ durante al menos 48 horas.

Propiedades mecánicas a bajas velocidades de deformación: se realizaron medidas de compresión, flexión y torsión. Estos experimentos se llevaron a bajas velocidades de deformación para determinar la rigidez y resistencia de los materiales. Las muestras fueron acondicionadas en idénticas condiciones a las de las medidas de densidad. Los experimentos de compresión fueron llevados a cabo en una máquina Instrom (modelo 5500R6025) bajo el estándar ASTM D $1621^{29}$, a temperatura ambiente y en un esquema de platos paralelos, con muestras de dimensiones 50×50×50 $\mathrm{mm}^{3}$. La máxima deformación estática alcanzada para todos los experimentos fue de aproximadamente el 75\%. La información obtenida de este tipo de experimentos fue el valor del módulo de elasticidad como la pendiente de la zona lineal en la representación del esfuerzo frente a la deformación, y el valor del esfuerzo de colapso, como el máximo de la curva en esta misma representación.

Las medidas de flexión fueron realizadas en las mismas condiciones ambientales y en el mismo equipo, pero esta vez bajo un esquema de carga de tres puntos, de acuerdo con el estándar ISO 178:2010 ${ }^{30}$, con dimensiones de las muestras $120 \times 15 \times 15 \mathrm{~mm}^{3}$. De estos experimentos fue posible obtener los valores del módulo de flexión, esfuerzo de flexión y deformación al máximo esfuerzo.

Finalmente, las medidas del módulo de cizalla se realizaron en la Universidad Católica de Lovaina (KUL), en Bélgica. De estas medidas se obtuvo el valor del módulo de cizalla, en 2 planos diferentes: en el plano que contiene la dirección de espumación del material y en un plano perpendicular a éste. 
Análisis Dinamo-mecánico (DMA): este tipo de medidas permite obtener las propiedades viscoelásticas de los materiales en función de la temperatura, tiempo y frecuencia, cuando son sometidos a un esfuerzo de tipo periódico. Para estas experiencias se empleó un equipo DMA/SDTA 861e de la casa Mettler Toledo configurado en modo de compresión, sobre muestras de forma cilíndrica con $12 \mathrm{~mm}$ de diámetro y un espesor de entre 4 y $6 \mathrm{~mm}$. Las medidas fueron realizadas a una frecuencia de $1 \mathrm{~Hz}$, con una tasa de calentamiento de 3 ㅇ $\mathrm{C} / \mathrm{min}$ entre $0^{\circ} \mathrm{C}$ y $190-200^{\circ} \mathrm{C}$. Se aplicó una fuerza estática de $18 \mathrm{~N}$ y una deformación de $30 \mu \mathrm{m}$ al 120\%, de manera que la fuerza estática aplicada sería un $120 \%$ de la fuerza dinámica aplicada. A lo largo de estas experiencias se registraron los valores del módulo de almacenamiento ( $\left.E^{\prime}\right)$, el módulo de pérdidas ( $E^{\prime \prime}$ ) y la tangente de perdidas (tag $\left.\delta\right)$.

Conductividad térmica: Para las medidas de conductividad térmica se emplearon 2 equipos diferentes: uno de ellos de la casa Holometrix basado en la ley de Fourier y otro basado en resolver la ecuación del calor en el regiment transitorio (método TPS, Hot disk). En el primero de los casos las medias se realizan estableciendo un gradiente de temperaturas entre dos de los lados del material, empleando un sensor de unos $100 \times 100 \mathrm{~mm}^{2}$ y bajo la norma UNE12667 ${ }^{31}$. Las temperaturas de medida fueron de $10,20,25,40$ y 50 ㄷ. Las muestras empleadas son considerablemente más grandes que para la otra de las técnicas, presentando también las medidas una mayor fiabilidad. Para el caso de las medidas en régimen transitorio, se empleó un elemento plano que actúa tanto como sensor de temperatura como de fuente de calor, produciendo un impulso eléctrico que genera un aumento de la temperatura. Las medias realizadas con esta técnica fueron realizadas bajo la norma ISO 22007-2:2008 ${ }^{32}$. La ventaja que supone esta técnica es su rapidez frente a la anteriormente descrita, así como la flexibilidad en las dimensiones de las muestras (de mucho menor tamaño), pero a su vez presenta la desventaja de que requiere un especial cuidado a la hora de conseguir reproducibilidad en las medidas.

Coeficiente de extinción: mediante un espectrómetro de infrarrojo de la casa Brunker (modelo Tensor 27) se realizaron medidas de la transmitancia sobre muestras con diferentes espesores, con el fin de calcular con los datos obtenidos el coeficiente de extinción. Se empleó una resolución de $2 \mathrm{~cm}^{-1}$, para un estudio de la región infrarroja que abarcó desde los 400 a los $4000 \mathrm{~cm}^{-1}$. 
Cinéticas de reacción: Con el mismo aparato empleado en la medida del coeficiente de extinción pero en vez de en transmisión en reflexión atenuada, se estudió el proceso de polimerización/espumación de materiales con y sin nanopartículas. Para ello se siguió la evolución temporal del pico característico del isocianato situado a $2270 \mathrm{~cm}^{-1}$.

\section{Caracterización Microscópica}

A continuación se detallan y se describen brevemente las diferentes técnicas de caracterización microscópicas empleadas:

Microscopia electrónica de barrido: mediante un microscopio electrónico de barrido modelo JEOL JSM 820 se obtuvieron micrografías de las muestras producidas para su posterior análisis mediante un software desarrollado en CellMat $^{36}$. A través de este programa y de las imágenes obtenidas se obtuvieron las distribuciones de tamaños celulares, el tamaño celular medio y la anisotropía celular de las diferentes muestras bajo estudio. También se calculó el parámetro de desviación estándar normalizada (NSD) y el coeficiente de asimetría de la distribución (AC).

$>$ Contenido de celda abierta: el porcentaje de celda abierta puede ser definido como la relación entre el volumen de celdas interconectadas y el volumen total de gas dentro de la espuma. Para su medida se empleó un picnómetro de aire (Eijkelcamp 08.06 Langer) y se siguió la norma ASTM D6226 ${ }^{33}$, sobre muestras cúbicas de arista $30 \mathrm{~mm}$, realizando una corrección por el volumen de las celdas cortadas en la superficie de la espuma.

> Tomografía de Rayos-X: se realizaron experiencias de tomografía de las muestras en la Universidad de Gante, con la finalidad de obtener la fracción de sólido presente en las aristas de la estructura celular de las muestras.

> Difracción de Rayos-X: Mediante esta técnica se estudió el grado de exfoliación de las nanoarcillas en las espumas, analizando el desplazamiento del pico de difracción asociado a la distancia interlaminar de las arcillas. En estos estudios se emplearon muestras de caras paralelas con dimensiones $48 \times 15 \times 2 \mathrm{~mm}^{3}$. 


\section{R.4. Resultados}

Se procede a continuación a la presentación de los principales resultados, divididos en 2 apartados diferentes, referentes a la técnica de dispersión empleada y a la concentración de nanoarcillas presente en los materiales.

Técnicas de dispersión: Se fabricaron muestras con una concentración fija del 3\% de nanoarcillas dispersada con diferentes técnicas: mezclado a mano, usando baja cizalla y mediante ultrasonidos (ver tabla R.3). Previamente se realizó un estudio de la dispersión de las nanoarcillas en el poliol de las 3 formulaciones seleccionadas. A continuación se muestran los principales resultados obtenidos en esta parte de la investigación:

D Estudio reológico: a través de este estudio se seleccionó la formulación con la menor viscosidad (BASF LV) para llevar a cabo la fabricación de espumas, pues mostró ser aquella que presentaba una mayor sensibilidad a la técnica de dispersión empleada. De esta manera se obtendrían unos materiales con diferentes estados de dispersión de las nanoarcillas, posibilitando el estudio del efecto de la dispersión sobre las propiedades finales.

> Densidad: por lo general se observó un ligero aumento de la densidad de las espumas por la incorporación de las nanoarcillas (respecto al material sin nanoarcillas), salvo en el caso del mezclado de baja cizalla. Este cambio puede atribuirse al aumento de la viscosidad en la mezcla inicial, que supondría una mayor resistencia a la hora de producirse el espumado y consecuentemente una mayor densidad, junto con el hecho de que se están introduciendo partículas de una alta densidad (Cloisite 30B - 1980 $\mathrm{kg} / \mathrm{m}^{3}$ ) en un material de muy baja densidad (poliuretano $-50 \mathrm{~kg} / \mathrm{m}^{3}$ ).

$>$ Tamaño de celda: se observó una reducción del tamaño de celda de en torno al 10\%, independientemente de la técnica de dispersión empleada, respecto al material sin nanoarcillas.

> Anisotropía celular: no se observaron efectos claros de las diferentes técnicas de dispersión en la anisotropía celular por la incorporación de nanoarcillas, con variaciones en torno al $10 \%$ respecto al material puro.

$>$ Porcentaje de celda abierta: con valores siempre por debajo del $10 \%$, la incorporación de las nanoarcillas, independientemente de la técnica con la 
que han sido dispersadas, no ha supuesto variación alguna de esta característica estructural.

> Distribución del tamaño de celda: el parámetro de distribución estándar (NSD) presentó un claro aumento (de 0.2 para el material puro a 0.3 para las diferentes técnicas), mientras que el coeficiente de asimetría se ha visto reducido por la presencia de las nanopartículas.

> Eficiencia de la nucleación: se estudió este parámetro obteniéndose similares valores a los observados en la bibliografía, siendo esta eficiencia baja.

- Intercalación de las nanoarcillas: el estudio de los resultados de las experiencias de difracción de Rayos-x sobre las muestras de poliuretano con nanoarcillas mostraron una intercalación de las mismas, con independencia de la técnica empleada. Los estudios de DMA corroboraron estos resultados, mostrando una clara reducción de la movilidad de las cadenas moleculares por la presencia de las nanoarcillas, que se manifestó en un aumento del valor de la temperatura de transición vítrea $\left(T_{g}\right)$ y un descenso del valor de $\tan \delta$.

> Propiedades a compresión (relativas al cuadrado de la densidad): la inclusión de nanoarcillas en las espumas de poliuretano ha supuesto un ligero aumento del módulo elástico de las espumas y una disminución de la resistencia a compresión, todo ello independientemente de la técnica de dispersión empleada. Estos cambios parecen atribuibles tanto a la modificación de la estructura celular como a posibles interacciones entre los puentes de hidrógeno de las cadenas poliméricas y las nanoarcillas.

$>$ Propiedades de cizalla: se han observado pequeñas diferencias por la introducción de nanoarcillas. Aun así los mayores cambios han sido observados entre las dos planos en las que se ha medido esta propiedad, mostrando su dependencia con la anisotropía celular y la dirección de crecimiento, con una clara mejora en el plano perpendicular a la dirección de espumación respecto al plano paralelo a la misma.

$>$ Conductividad térmica: se ha detectado una reducción de la conductividad térmica tras la introducción de las nanoarcillas. Este resultado es el esperable tras la reducción del tamaño de celda observada y la estrecha relación que existe entre ambas características. 
Diferentes concentraciones: Se fabricaron muestras con cuatro concentraciones diferentes de nanoarcillas $(0.5,1,3$ y 5\%) dispersadas a baja cizalla, así como muestras de material sin nanoarcillas. A continuación se resumen los principales resultados obtenidos:

Densidad: salvo en el caso de la menor concentración de nanoarcillas (0.5\%) donde se observó una pequeña disminución de la densidad, por lo general se observó un ligero aumento de la densidad de las espumas por la incorporación de las nanoarcillas (respecto al material sin nanoarcillas). Al igual que en el estudio de las diferentes técnicas de dispersión, este cambio puede atribuirse al aumento de la viscosidad en la mezcla inicial, que supondría una mayor resistencia a la hora de producirse el espumado y consecuentemente una mayor densidad, junto con el hecho de que se están introduciendo partículas de una alta densidad (Cloisite 30B - 1980 $\mathrm{kg} / \mathrm{m}^{3}$ ) en un material de muy baja densidad (poliuretano $-50 \mathrm{~kg} / \mathrm{m}^{3}$ ).

$>$ Tamaño de celda: se observó una reducción del tamaño de celda por la incorporación de las nanoarcillas, existiendo una correlación clara con la cantidad de nanoarcillas incorporadas hasta el 3\%, donde se alcanza un máximo de reducción del $24 \%$ respecto al material sin carga. Asimismo, en el caso de la concentración más alta de nanoarcillas (5\%) también se observó una reducción respecto al material puro, pero no tan acusada (21\%).

> Anisotropía celular: se ha observado una ligera reducción del valor de la anisotropía celular a medida que se ha aumentado la concentración de nanoarcillas.

$>$ Porcentaje de celda abierta: Aun manteniéndose por debajo del $10 \%$, sí se ha observado una cierta variación en el porcentaje de celda abierta por la incorporación de las nanoarcillas, con valores de esta propiedad en torno al $6.5 \%$ para el material puro y con un $0.5 \%$ de nanoarcillas, y del $8.5 \%$ para el resto de muestras.

> Fracción de masa en las aristas: se han observado cambios considerables en esta propiedad con el aumento de la concentración de nanoarcillas. Mientras que para el material puro y las muestras con un 0.5 y un $1 \%$ de nanoarcillas se han medido valores en torno al 0.66 , para el $3 \%$ de nanoarcillas el valor se incrementó hasta el 0.78 , y para el 5\% se midió un 0.76. Estos cambios han implicado alteraciones medibles en propiedades 
como el coeficiente de extinción y la conductividad térmica. Su origen puede encontrarse en los cambios producidos en la viscosidad de la mezcla poliol-nanoarcillas a medida que aumentaba la concentración de estas últimas, cambios que pueden alcanzar una importancia considerable durante la formación y estabilización de la estructura celular. Otra posible explicación, compatible con la anterior, puede encontrarse en las modificaciones de la cinética de las reacciones producidas por las nanoarcillas. La presencia de nanoarcillas puede alterar la cinética de polimerización, la de espumado o ambas, como se ha podido observar en pruebas iniciales mediante el empleo de FTIR para la medida de estas reacciones.

Distribución del tamaño de celda: el parámetro de distribución estándar (NSD) presentó un claro aumento. De hecho, para el material con un 5\% de nanoarcillas se ha observado una distribución de celdas bimodal (un valor del NSD de 0.62 para la muestra con $5 \%$ de nanoarcillas frente a 0.20 para el material puro). El coeficiente de asimetría también ha mostrado un aumento por la presencia de las nanopartículas.

> Eficiencia de la nucleación: se estudió este parámetro observándose similares valores a los presentes en la bibliografía, con un valor de la eficiencia de nucleación bajo.

> Intercalación de las nanoarcillas: el estudio de los resultados de las experiencias de difracción de rayos $\mathrm{X}$ sobre las muestras de poliuretano con nanoarcillas mostraron, para las diferentes concentraciones, una intercalación de las nanoarcillas.

> Propiedades a compresión (relativas al cuadrado de la densidad): la inclusión de nanoarcillas en las espumas de poliuretano ha supuesto un ligero aumento del módulo elástico de las espumas (hasta el $12 \%$ respecto al material puro para una concentración de arcillas del 3\%) y una disminución de la resistencia a la compresión (esfuerzo de colapso, reducción del 1 al 5\% respecto al material puro). Estos cambios parecen atribuibles tanto a la modificación de la estructura celular como a posibles interacciones entre los puentes de hidrógeno de las cadenas poliméricas y las nanoarcillas. El aumento de la cantidad de nanoarcillas presentes no sólo no ha supuesto un aumento de las propiedades a compresión sino que incluso ha llevado a su disminución. 
Propiedades a flexión: Se ha observado una disminución de la deformación al máximo esfuerzo, con una reducción de más del 50\% respecto al material puro para las mayores concentraciones de nanoarcillas. También se han observado aumentos en el módulo de flexión, pero sin una tendencia clara con respecto a la cantidad de nanoarcillas. Para el esfuerzo de flexión se ha observado una reducción significativa, pasando de los 0.73 MPa del material puro a un valor medio de $0.65 \mathrm{MPa}$ para los materiales con nanoarcillas.

> Propiedades de cizalla: se han observado pequeñas diferencias por la introducción de nanoarcillas. Aun así los mayores cambios han sido entre los dos planos en las que se ha medido esta propiedad, mostrando su dependencia con la anisotropía celular y la dirección de crecimiento. De nuevo, las mejores propiedades han sido observadas en el plano perpendicular a la dirección de espumación.

- Conductividad térmica: La evolución temporal de la conductividad térmica ha venido marcada por la difusión del agente hinchante $\left(\mathrm{CO}_{2}\right)$ a la atmósfera. Aproximadamente 12 días después de la fabricación del material la conductividad térmica alcanzó un estado estacionario, donde se observó una reducción de la conductividad térmica en las muestras con baja concentración de nanoarcillas respecto al material puro. Esta mejora pude ser considerada en una primera aproximación un efecto secundario de la reducción en el tamaño celular producido por las nanoarcillas, dada la gran dependencia entre estas dos propiedades. Para el $1 \%$ de nanoarcillas se observó el mínimo de conductividad térmica, y con la finalidad de entender mejor los cambios producidos se procedió a realizar una modelización de esta propiedad.

Modelización de la conductividad térmica: teniendo en cuenta los valores medidos de tamaño de celda, fracción de masa en aristas y coeficiente de extinción, se procedió a realizar una modelización de la conductividad térmica de los materiales. Para ello se tuvieron en cuenta los diferentes mecanismos de transmisión del calor involucrados en los materiales celulares: transmisión a través de la fase gaseosa, transmisión por radiación y transmisión de la fase sólida. El primero de los mecanismos es el que tiene un mayor peso sobre la conductividad total (en torno al 70\%) y no experimentó cambios apreciables por la presencia de las nanoarcillas. 
La transmisión por radiación sí que mostró cambios por la presencia de nanoarcillas, como se puede deducir de los cambios en la estructura celular y en el coeficiente de extinción, si bien en los modelos aplicados se echa en falta el tener en cuenta la posible absorción/reflexión de la radiación en las arcillas que permitiese un perfecto ajuste entre los datos experimentales y los proporcionados por los modelos. Finalmente, para el caso de la conducción a través del sólido, no se observa una correspondencia entre modelo y resultados experimentales, pudiéndose deber esto a la creación por parte de las nanoarcillas de una red de percolación para concentraciones por encima del 1\%, efecto que incrementaría la conducción a través de la fase sólida que no se habría tenido en cuenta en la modelización.

\section{R.5. Conclusiones y trabajo futuro}

Las conclusiones obtenidas del presente trabajo se pueden clasificar en tres apartados diferenciados:

- Metodología de fabricación y caracterización: cabe resaltar como resultado destacable del presente trabajo el establecimiento de una metodología de fabricación y caracterización para espumas de poliuretano. Como bien ha sido resaltado en la introducción, las espumas de poliuretano son una nueva área de estudio dentro del grupo CellMat, y como resultado del presente trabajo ha sido y será posible el desarrollo de nuevos proyectos en dicha área de manera mucho más efectiva, con un menor gasto de recursos y tiempo.

Se puede concluir que este trabajo presenta una colección de técnicas de caracterización, de índole tanto experimental como teórica, que puede ayudar a una mejor comprensión de diferentes sistemas de poliuretano y nanoarcillas, aspecto fundamental y necesario para la elección de la nanopartícula a utilizar en cada material en concreto.

- Dispersión de las nanopartículas: mediante el estudio de la dispersión de las nanopartículas que ha sido llevado a cabo de manera previa a la fabricación de las muestras finales, este trabajo ha ayudado a entender la dependencia de la calidad de la dispersión respecto a la viscosidad del 
reactivo, la dependencia también respecto de la potencia de la técnica empleada así como la relación entre las propiedades finales del material producido y la técnica de dispersión empleada. Estos resultados son de gran importancia en la elaboración de nanocomposites dado el alto número de partículas presentes incluso para bajas concentraciones de nanopartículas.

- Estructura celular, propiedades mecánicas y térmicas: finalmente, refiriéndonos ya a los materiales celulares finales, los resultados obtenidos en el desarrollo del presente trabajo han llevado a dos conclusiones fundamentales. Por un lado es fácil alcanzar buenos resultados con la introducción de pequeños porcentajes de nanoarcillas, sin la necesidad de recurrir a una técnica de dispersión demasiado cara o laboriosa para la obtención de estos resultados. Por otro lado la pequeña mejora, incluso la disminución, de las propiedades mecánicas para concentraciones altas de nanoarcillas es síntoma del claro efecto que presenta la interacción entre la matriz polimérica y las nanopartículas en las espumas rígidas de poliuretano. Dado que la alteración de los enlaces puente de Hidrógeno por la presencia de las nanoarcillas parece ser la responsable de este empeoramiento, es necesario prestar especial atención a la relación de aspecto de las nanopartículas y a su funcionalización superficial, por lo menos en los casos en los que se trate de buscar una mejora de las propiedades mecánicas.

Desde el punto de vista morfológico ha sido posible observar una clara reducción del tamaño celular, achacable en gran medida a la presencia de las nanopartículas en la matriz polimérica y su efecto nucleante. Esto ha sido observado para todas las técnicas de dispersión empleadas y también para las diferentes concentraciones, si bien ha sido acompañado a su vez por una mayor dispersión de los tamaños de celda observados. Para las concentraciones más altas de nanopartículas se ha observado una considerable variación de la forma de repartirse el material en la estructura celular, con un aumento de la fracción de masa en las aristas. Otras propiedades como la conductividad térmica, altamente dependiente de características morfológicas como el tamaño de celda y la fracción de 
Resumen de la tesis en Español

masa en aristas, han presentado mejoras incluso para las técnicas de dispersión más sencillas.

\section{Trabajo futuro}

Tras el trabajo realizado para la elaboración de esta tesis, varios temas de investigación serán afrontados por CellMat en los próximos años. A continuación se muestran algunos de ellos:

1. Realizar un estudio similar pero con una selección más apropiada de los materiales de partida. La experiencia obtenida del presente trabajo permitirá una mejor selección de la formulación de poliuretano y de la funcionalización de las nanoarcillas para una mejora de las propiedades con la ayuda de las nanoarcillas.

2. Establecer una metodología para analizar la cinética de las reacciones implicadas, que incluiría FTIR, termografía, radioscopia de rayos-X y expandometría óptica. Se espera con ello poder tener una mayor comprensión del efecto de las nanopartículas durante el proceso de espumación.

3. Esclarecer diversos aspectos en la modelización de la conductividad térmica, en particular los cambios en las propiedades ópticas del polímero base y el cambio de las propiedades de la fase sólida por la presencia de las nanoarcillas.

4. Desarrollar nuevos procedimientos que ayuden a una mejor dispersión y exfoliación de las nanopartículas.

\section{R.6. Artículos y congresos}

Durante el desarrollo del presente trabajo, se llevaron a cabo las siguientes presentaciones en congresos:

M.A. Rodriguez-Perez, J. Pinto, J. Escudero, A. Lopez-Gil, E. Solorzano, C. Saiz-Arroyo, S. Estravis, S. Pardo-Alonso, Nano-strategies applied to the production of cellular polymers with improved cellular structure and properties. CellMat Conference, Dresden, Germany, 2012. (Talk)

S. Estravis , M.A. Rodriguez-Perez, Polyurethane foam composites: relationship between mechanical properties and filler matrix chemical interaction, SPE Eurotec Conference, Barcelona, Spain, 2011. (Talk) 
S. Pardo, S. Estravís, E. Solórzano, M.A. Rodríguez-Pérez, J.A. de Saja, Effect of nanoadditves in rigid polyurethane foam nucleation monitored by X-ray radioscopy, SPE Eurotec Conference, Barcelona, Spain, 2011. (Talk)

S. Estravis, M.A. Rodriguez-Perez, Modification of the mechanical properties of polyurethane composites by using wastes of flexible polyurethane and sawdust as additives, FOAMS 2010, Seattle, EEUU, 2010. (Poster)

P. Álvarez, A. Echeverría, M.M. Petite, M.A. Rodríguez-Pérez, J. Pinto, S. Estravis, M.A. Martines, J. Abenojar, Fabrication, characterization and modeling of sandwich panels with polyethylene and polyurethane foams cores and aluminum skins, Comatcomp 09, San Sebastián, Spain, 2009. (Poster)

M.A. Martínez, J. Abenojar, M.A. Rodríguez-Pérez, J. Pinto, S. Estravis, J. Ecenero, E. Aldanondo, P. Álvarez, Polyolefin and polyurethane foam-aluminum joins: adhesion tests and modeling, $\mathbf{X}$ Congreso de Adhesión y Adhesivos, Alicante, Spain, 2009. (Poster)

S. Estravis, J.A. de Saja, R. Verdejo, M.M. Bernal, M.A. Rodríguez-Pérez, Improving the mechanical properties of rigid PU foams using nanofillers, XI Reunión del GEP, Valladolid, Spain, 2009. (Poster)

De manera adicional, se realizaron o están próximas a realizarse las siguientes publicaciones:

S. Pardo-Alonso, E. Solórzano, S. Estravis, M.A. Rodriguez-Perez, J.A. de Saja, In-situ Evidences of Nanoparticles Nucleating effect in Polyurethane-Nanoclay Foamed Systems, Soft Matter (2012) 8, 11262. DOI: 10.1039/C2SM259983D.

M. Bernal, I. Molenberg, S. Estravis, M.A. Rodriguez-Perez, I. Huynen, M.A. Lopez-Manchado,

R. Verdejo, Comparing the effect of carbon-based nanofillers on the physical properties of flexible polyurethane foams, Journal of Material Science (2012) 47 (15) 5673-5679.

S. Estravís, M. A. Rodríguez-Pérez , J. Tirado, S. Pardo-Alonso; Rigid polyurethane foams with infused nanoclays: relationship between cellular structure and thermal conductivity, Journal of Polymer Science, 2014. (Submitted)

R. Van Hooghten, S. Gyssels, S. Estravis, M.A. Rodriguez-Perez, P. Moldenaers, Understanding the effect of particle free energy on the structural and mechanical properties of clay-laden rigid PU foams, European Polymer Journal, 2014 (Submitted)

S. Estravís, R. Van Hooghten, M. A. Rodríguez-Pérez, R. Cardinaels, P. Moldenaers and J. Vermant; Effect of dispersion quality on the structure and properties of polyurethane foams infused with clays. (in preparation)

S. Estravís, R. Van Hooghten, M. A. Rodríguez-Pérez, R. Cardinaels, P. Moldenaers and J. Vermant; Effect of nanoparticles concentration on the structure and properties of polyurethane foams infused with nanoclays. (in preparation) 
Resumen de la tesis en Español

\section{R.7. Aplicación de los resultados obtenidos en procesos industriales}

El conocimiento generado en el presente trabajo ha sido empleado de manera satisfactoria para la realización de los siguientes proyectos con socios privados:

- Espumas de poliuretano para la producción de tablas de surf. Foam Asturblank (2009-2010)

- Uso de nanopartículas de sepiolita para la optimización de estructura y propiedades en espumas de base PS y PU. TOLSA S.A. (2012-2013)

- Desarrollo de nuevas espumas de poliuretano con mejoras en sus propiedades aislantes.

(Bosch and Siemens Home appliances Group) (2012-2013). 


\section{BIBLIOGRAFÍA}

${ }^{1}$ M.A. Rodríguez-Pérez, Propiedades Térmicas y Mecánicas de Espumas de Poliolefinas, Thesis, University of Valladolid, (1999)

2 O. Almanza, Caracterización y Modelización de las Propiedades Térmicas y Mecánicas en Espumas de Poliolefinas, Thesis, University of Valladolid, (2000)

3 L.O. Arcos y Rábago, Propiedades Térmicas y Mecánicas de Espumas de Poliolefinas Fabricadas en un Proceso de Moldeo por Compresión, Thesis, University of Valladolid, (2002)

4 J.L. Ruiz-Herrero, Impacto y Fluencia de Espumas con Base Polietileno, Thesis, University of Valladolid, (2004)

${ }^{5}$ J.I. González-Peña, Efecto de los Tratamientos Térmicos en Bloques de Espuma de Polietileno de Baja Densidad Producidos Mediante Moldeo por Compresión, Thesis, University of Valladolid, (2006)

${ }^{6}$ M. Álvarez-Laínez, Propiedades Térmicas, Mecánicas y Acústicas de Espumas de Poliolefina de Celda Abierta, Thesis, University of Valladolid, (2007)

${ }^{7}$ J. A. Reglero Ruiz, Fabricacion y Caracterización de espumas de aluminio: aplicaciones en el sector aeronáutico, Thesis, University of Valladolid, (2007)

${ }^{8}$ E. Solórzano, Aluminum foams: Foaming process, cellular structure \& properties, Thesis, University of Valladolid, (2008)

${ }^{9}$ F. Hidalgo-González, Diseño Optimizado de los Parámetros de Proceso de Fabricación de Espuma de Poliolefina Reticulada mediante Moldeo por Compresión, Thesis, University of Valladolid, (2008)

${ }^{10}$ S. Román-Lorza, Fabrication and characterization of flame retardant halogen free polyolefin based cellular materials, Thesis, University of Valladolid, (2010)

11 R. Campo-Arnáiz, Aplicación de Técnicas Espectroscópicas al Estudio de la Morfología Polimérica, Propiedades Térmicas y de Emisión de Espumas de Baja Densidad con Base Poliolefina, Thesis, University of Valladolid, (2011)

${ }^{12}$ C. Saiz Arroyo, Fabricación de materiales celulares mejorados basados en poliolefinas. Relación procesado-composición-estructura-propiedades, Thesis, University of Valladolid, (2012)

${ }^{13} \mathrm{~J}$. Lobos Martín, Improving the stiffness and strength of porous materials by enhancement of the matrix microstructure and cellular morphology, Thesis, University of Valladolid, (2013)

${ }^{14}$ http://polyurethane.americanchemistry.com/

${ }^{15}$ Polyurethane (PU) Foams Market by Types (Rigid \& Flexible), End-User Industries (Bedding \& Furniture, Building \& Construction, Electronics, Automotives, Footwear, Packaging, \& Others), 
\& Geography (North America, West Europe, Asia-Pacific \& Row) - Global Trends \& Forecasts to 2018, http://www.marketsandmarkets.com/Market-Reports/polyurethane-foams-market1251.html

${ }^{16}$ L. J. Lee, C. Zeng, X. Cao, X. Han, J. Shen, G. Xu, Polymer nanocomposite foams, Composites Science and Technology, 65(15-16), 2344-2363, (2005)

17 S. Pavlidou, C.D. Papaspyrides, A review on polymer-layered silicate nanocomposites, Progress in Polymer Science, 33, 1119-1198, (2008)

${ }^{18}$ R. Verdejo, C. Saiz-Arroyo, J. Carretero-Gonzalez, F. Barroso-Bujans, M.A. Rodriguez-Perez, M.A. Lopez-Manchado, Physical properties of silicone foams filled with carbon nanotubes and functionalized graphene sheets, European Polymer Journal, 44, 2790-2797 (2008)

19 J.I. Velasco, M. Ardanuy, V. Realinho, M.Antunes, A.I. Fernández, J.I. González-Peña, M.A. Rodríguez-Pérez, J.A. de Saja, Polypropylene/clay nanocomposites: combined effects of clay treatment and compatibilizer polymers on the structure and properties, Journal of Applied Polymer Science, 102, 1213-1223 (2006)

20 J. Weiss, P. Takhistov, D.J. McClements, Functional materials in food nanotechnology, Journal of Food Science, 71(9), R107-R116, (2006)

${ }^{21}$ Q. H. Zeng, A. B. Yu, G. Q. Lu, D. R. Paul, Clay-based polymer nanocomposites: research and commercial development, Journal of nanoscience and nanotechnology, 5(10), 1574-1592, (2005)

${ }^{22}$ M. Modesti, A. Lorenzetti, S. Besco, D. Hrelja, S. Semenzato, R. Bertani, R.A. Michelin, Synergism between flame retardant and modified layered silicate on thermal stability and fire behaviour of polyurethane nanocomposite foams, Polymer Degradation and Stability, 93, 2166-2171, (2008)

${ }^{23}$ H. A.Patel, R. S. Somani, H. C. Bajaj, R. V. Jasra, Nanoclays for polymer nanocomposites, paints, inks, greases and cosmetics formulations, drug delivery vehicle and waste water treatment, Bulletin of Materials Science, 29(2), 133-145, (2006)

${ }^{24}$ D. Shah, P. Maiti, D. D. Jiang, C. A. Batt, E. P. Giannelis, Effect of nanoparticle mobility on toughness of polymer nanocomposites, Advanced Materials, 17(5), 525-528, (2005)

${ }^{25}$ T. Kashiwagi, F. Du, J. F. Douglas, K. I. Winey, R. H. Harris, J. R. Shields, Nanoparticle networks reduce the flammability of polymer nanocomposites, Nature Materials, 4(12), 928-933, (2005)

${ }^{26}$ X. Cao, L. J. Lee, T. Widya and C. Macosko, Polyurethane/clay nanocomposites foams: processing, structure and properties, Polymer, 46, 775-783, (2005)

${ }^{27}$ T. Widya, C. W. Macosko, Nanoclay-modified rigid polyurethane foam, J. of Macrom. Sci., Part B: Phys., 44(6), 897-908, (2005) 
${ }^{28}$ ASTM D1622 - 08: Standard Test Method for Apparent Density of Rigid Cellular Plastics, ICS Number Code 83.100 (Cellular materials), DOI: 10.1520/D1622-08

${ }^{29}$ ASTM D1621: Standard Test Method for Compressive Properties Of Rigid Cellular Plastics, ICS Number Code 83.100 (Cellular materials), DOI: 10.1520/D1621-10

${ }^{30}$ EN ISO 178, Plastics - Determination of flexural properties, European Committee for Standardization (CEN), (2010)

31 UNE-EN 12667:2002, Thermal performance of building materials and products. Determination of thermal resistance by means of guarded hot plate and heat flow meter methods, Products of high and medium thermal resistance, (2002)

${ }^{32}$ ISO 22007-2. 2008. Plastics-Determination of Thermal Conductivity and Thermal DiffusivityPart 2: Transient Plane Heat Source (Hot Disc) Method (2008)

${ }^{33}$ ASTM D6226 - 10: Standard Test Method for Open Cell Content of Rigid Cellular Plastics, ICS Number Code 83.080.01 (Plastics in general), DOI: 10.1520/D6226-10

${ }^{34}$ Ł.Piszczyk, M. Strankowski, M. Danowska, J. T. Haponiuk, M. Gazda, Preparation and characterization of rigid polyurethane-polyglycerol nanocomposite foams, European Polymer Journal, 48(10), 1726-1733, (2012)

${ }^{35}$ H.H. Winter, Three views of viscoelasticity for Cox-Merz materials, Rheologica acta, 48(3), 241-243, (2009)

${ }^{36}$ J. Pinto, E. Solórzano, M. A. Rodriguez-Perez, J. A. de Saja, Characterization of the celular structure based on user-interactive image analysis procedures, Journal of Cellular Plastics, 49(6), 555-575, (2013) 

CHAPTER 1: INTRODUCTION 



\section{INTRODUCTION}

\section{1.- Motivation}

One of the main motivations of this research has been establishing a new research topic in polyurethane foams in the CellMat Laboratory, of the Condensed Matter Physics Department of the University of Valladolid. CellMat was founded in 1999 by Professor Dr. D. José Antonio de Saja and Professor Dr. D. Miguel Ángel Rodríguez Perez, with the aim of studying cellular materials. From that time up to now, Cellmat has been focused on several topics such as: development of new production routes for cellular materials, obtaining lighter multi-functional products with improved properties, creating new knowledge on the relationship processing-structure-properties-applications, modelling the physical behaviour of cellular materials and designing applications using these products.

The scientific production of CellMat Laboratory ${ }^{1-13}$ has been mainly related to thermoplastic foams and aluminium based foams, and in particular in the case of thermoplastic foams mainly in polyolefin based materials. However the market presence of these particular materials was (and still is) much smaller than that of the cellular polymers such as polyurethane (PU), polystyrene (PS) and polyvinyl chloride (PVC). This was one of the key reasons to establish a new research area focused on polyurethane foams.

Polyurethane foams have a wide range of applications in different industries such as automotive, sports equipment, furniture, construction and much more, and therefore a great economical weight. Only in the United States, business of polyurethane has an estimated value of $\$ 20$ billion and it is a key element of the U.S. economy, employing directly more than 200.000 people $^{14}$. Globally, the current estimated value of the global Polyurethane Foams Market (2012) is $\$ 40.1$ billion and is estimated to reach up to $\$ 61.9$ billion by $2018^{15}$. The origin of this high values is largely due to the high applicability of polyurethane foams mainly based on the possibility of tailoring the final properties of the material with just a change in the initial components. In addition, the "apparent" simplicity of the foaming technology has made these materials very competitive from an economical perspective.

Furthermore, the growing field of nanotechnology has also had a considerable impact in CellMat Laboratory research. In general terms, nanoparticles could have a significant impact over the materials industry and in particular over polyurethane foams world, opening new tailoring options for these materials. The use of nanoparticles in scientific research has increased exponentially in the last few years ${ }^{16-19}$, and even some of the advantages of this 
technology have reached market ${ }^{20,21}$. Employed as additive in conventional materials, its presence can suppose not only the reinforcement of certain material properties, but also the emergence of new properties ${ }^{22}$. Among the vast nano-reinforcements available for fabricating polymer nanocomposites, nanoclays are one of the most studied materials ${ }^{12,23-25}$. The reason of this success is that nanoclays are naturally occurring minerals that are commercial available, exhibit a layered morphology with high aspects ratios, large specific surface areas, and have substantial cation exchange capacities.

For all the previously exposed reasons, polyurethane foams infused with nanoclays is an actual research topic with high potential, which explains the generated interest in CellMat Laboratory over this particular materials. Several works have been published previously in this field. For instance Modesti et al. ${ }^{22}$ studied potential synergies in flame retardancy between phosphorus-based flame retardant (aluminium phosphinate) and layered silicates in polyurethane foams, obtaining that clays act through physical effect constituting a barrier at the surface which is effective in preventing or slowing the diffusion of volatiles and oxygen. The processing, structure and properties of polyurethane-clay nanocomposites foams, both rigid and flexible, were studied by Cao et al. ${ }^{26}$, observing an increase in cell density, a reduction of cell size for nanocomposites compared to pure PU foam and a reduction of the $T_{g}$ and the mechanical properties for rigid foams. Widya and Macosko ${ }^{27}$ incorporated different montmorillonite based organoclay concentrations (1, 2, 3 and 5\%wt.) into rigid polyurethane foams with ultrasonication dispersion, obtaining a cell size reduction and a cell density increase even for the lower nanoclays concentration. There are several additional examples that will be explained in detail in chapter 2 .

The present work explores the effect of incorporating nanoclays on the foam structure, mechanical and thermal properties of rigid polyurethane systems in a different way to previous literature. Although nanoclays incorporation to rigid polyurethane foams is considered in previous literature, a more detailed study on aspects such as dispersion quality, degree of exfoliation, influence of the particles on the cellular structure, physical and chemical mechanisms influencing the physical properties and properties modelling is missing. The previous published papers have been tipically focused on a wide range of nanometric particles, even polyurethane formulations, and this implies a less detailed study of each particular system. In several cases, density and cellular structure has not been deeply studied, which is a crucial aspect for this kind of materials. In general terms aspects such as dispersion and exfoliation of the nanoparticles, properties modelling have not been also considered in detail. Due to the previous reasons, a particular formulation and a certain kind of functionalized 
nanoclays have been selected for this thesis, with the objective to carry out a detailed study of this particular system. With all the data obtained from the characterisation and the use of different theoretical models, the origin of the changes in the final properties are identified, giving these results the possibility to analyze the influence of the different parameters that have been modified by the nanoclays addition.

Another event that had a considerable influence on the development of the present work is the participation of CellMat Laboratory in the European project entitled "NANCORE: Microcellular nanocomposite for substitution of Balsa wood and PVC core material" belonging to the Seventh European Framework. The main objective of this project was to design a novel and cost-effective microcellular nanocomposite foam, with mechanical properties comparable to or better than Balsa wood and PVC foam, allowing for a substitution of these materials in the core of lightweight composite sandwich structures. Nowadays, these two materials are widely used in energy and transport applications, with the annual EU and US markets for such sandwich structures estimated to exceed 2 billion Euro. Besides the prospect of a significant cost decrease, the development of a new core material would help to solve serious market imperfections and supply problems suffered by European consumers of both PVC foam and Balsa wood. Specifically, the NanCore project aimed at achieving a cost reduction of at least 30 percent for the finished core material as compared to current core materials, of which Balsa wood is the cheapest. At the same time, the material developed should display mechanical properties allowing for application in wind power, as the primary and most demanding of the industries targeted. The consortium behind this project consisted of a group of leading industrial end-users of composite materials in combination with research groups with an expertise in material science (see table 1.1). During this project CellMat was in charge of leading Work Package 3 (WP3): "Foaming of nanocomposites". An important part of the research activity was focused on improving PU formulations supplied by the industrial partner Recticel, by incorporating nanoclays. In addition, some of the research (mainly the analysis of the dispersion of the particles) was carried out in collaboration with the Katholic University of Leuven (KUL), which was one of the partners in this consortium. 


\begin{tabular}{|c|c|c|}
\hline $\begin{array}{l}\text { Participant } \\
\text { name }\end{array}$ & Country & Main Activities \\
\hline $\begin{array}{l}\text { LM Glasfiber } \\
\qquad \mathrm{A} / \mathrm{S} \\
\text { (Coordinator) }\end{array}$ & Denmark & $\begin{array}{l}\text { Requirement specification with regard to process, production and } \\
\text { mechanical characteristics; demonstration and full-scale testing; } \\
\text { Consortium Management; integration of microcellular polymer } \\
\text { nanocomposite (MNPC) into a sandwich structure }\end{array}$ \\
\hline $\begin{array}{l}\text { Aalborg } \\
\text { University }\end{array}$ & Denmark & $\begin{array}{l}\text { Multi-scale modeling and simulations of microcellular nano- } \\
\text { composites; integration of MNPC into a sandwich structure; Selection } \\
\text { of functionalized components of polymer nanocomposites }\end{array}$ \\
\hline $\begin{array}{c}\text { Recticel } \\
\text { Polyurethanes }\end{array}$ & Belgium & $\begin{array}{c}\text { Development of polyurethane formulations. Fabrication of } \\
\text { polyurethane foams at industrial scale. }\end{array}$ \\
\hline
\end{tabular}

\section{Katholieke}

Universiteit Belgium

Leuven
Rheological characterisation of nanocomposites; multi-scale modeling and simulations of microcellular nano-composites; integration of MNPC into a sandwich structure.

\begin{tabular}{c|c|c|}
$\begin{array}{c}\text { Universität } \\
\text { Kassel }\end{array}$ & Germany & $\begin{array}{r}\text { Industrial processing of microcellular nano-composites; mechanical } \\
\text { characterisation of foamed sandwich panels }\end{array}$ \\
$\begin{array}{c}\text { University of } \\
\text { Valladolid }\end{array}$ & Spain & $\begin{array}{r}\text { Production and characterisation of foams at lab scale; analysis of } \\
\text { foaming mechanism }\end{array}$ \\
\hline $\begin{array}{c}\text { Azimut-Benetti } \\
\text { S.P.A. }\end{array}$ & Italy & $\begin{array}{r}\text { Requirement specification with regard to process; integration of } \\
\text { MNPC into a sandwich structure; demonstration and full-scale testing. }\end{array}$ \\
\hline
\end{tabular}

Centre of Molecular and Macromolecular Poland

Studies
Selection of functionalized components of polymer nanocomposites and elements of foaming processes; production and characterisation of solids PP nanocomposites for foaming applications

\begin{tabular}{|c|c|c|}
\hline $\begin{array}{l}\text { Institute of } \\
\text { Occupational } \\
\text { Medicine }\end{array}$ & $\begin{array}{l}\text { United } \\
\text { Kingdom }\end{array}$ & Safety Issues of Nanoparticles from nanocomposites \\
\hline $\begin{array}{l}\text { Technical } \\
\text { University of } \\
\text { Denmark }\end{array}$ & Denmark & Life Cycle Assessment of new core material \\
\hline EconCore N.V. & Belgium & Integration of MNPC into a sandwich structure \\
\hline FOCAL Limited & $\begin{array}{l}\text { United } \\
\text { Kingdom }\end{array}$ & $\begin{array}{l}\text { Requirement specification with regard to proces; integration of MNPC } \\
\text { into a sandwich structure; demonstration and full-scale testing }\end{array}$ \\
\hline $\begin{array}{l}\text { Sekisui Alveo } \\
\qquad \text { AG }\end{array}$ & Switzerland & Production of PP foamed nanocomposite at industrial scale \\
\hline
\end{tabular}

TABLE 1.1. Participants and main activities in FPVII Nancore project. 


\section{2.- Objectives}

As this work has been the first contact of CellMat Laboratory with polyurethane foams, the objectives are not only restricted to the polyurethane-nanoclays systems under study, but they are also connected with setting up a collection of techniques and knowledge useful in future research projects on polyurethane foams. Due to this, the main objectives of this research work can be divided into Methodological Objectives and Scientific Objectives.

\section{Methodological Objectives:}

- Setting up the production process of rigid polyurethane foams containing nanoparticles: the objective is to set a standard procedure in order to reach reproducibility in the samples production, eliminating any foam change due to non-controlled variables. This procedure showed to be valid for the production of both un-reinforced and reinforced (with nanoparticles) polyurethane foams, ensuring a good cellular structure and physical properties. To carry out this activity several sub-objectives showed to be fulfilled:

Selection of rigid polyurethane formulations

Selection of nanoparticles

Optimization of the dispersion methods for the nanoparticles

Optimization of the processing parameters for the foams production

- Optimization of the polyurethane foams characterization techniques. Different characterization techniques previously employed by CellMat Laboratory for other type of foams (mainly flexible foams) has been adapted for the characterization of polyurethane rigid foams. Table 1.2 presents these characterisation techniques together with the corresponding standard typically used (for those in which there is a standard). All the methods have been adapted in a large or small extend. In particular the techniques that have required a larger effort have been the analysis of nanoparticles dispersion (by rheological methods) and the measurement of the extinction coefficient by using infrared spectroscopy. 


\begin{tabular}{|c|r|r|}
\hline Characterization technique & Experimental facility & Method \\
\hline Density measurement & Mettler Toledo AT261 & ASTM D1622 \\
\hline $\begin{array}{c}\text { Mechanical properties: compression } \\
\text { tests }\end{array}$ & Instron universal testing machine, & ASTM D1621 \\
\hline Mechanical properties: bending test & model 5500R6025 & \\
& Instron universal testing machine, & ISO 178:2010 \\
\end{tabular}

Mechanical properties: torsion test

TA-instrument, Ares-melts

rheometer

Dynamic Mechanical Analysis (DMA) Mettler Toledo DMA/SDTA 861e

Holometrix Rapid K Heat Flow

Thermal Conductivity

Meter

UNE12667

\section{Meter}

\begin{tabular}{|l|l|}
\hline Thermal Conductivity & Hot-disk transient plane source \\
thermal constant analyser (TPS)
\end{tabular}

ISO 22007-2:2008

\section{Infrared Spectroscopy (Determination of the extinction coefficient)}

Scanning Electron Microscopy (SEM)

Open cell measurement

Eijkelcamp 08.06 Langer

Bruker Tensor 27 FTIR

spectrometer

JEOL JSM 820

X-ray tube FXE- 160.50 source

from Feinfocus, detection system

X-ray tomography

PerkinElmer XRD 1620 CN3,

rotary stage from MICOS (UPR-

160F AIR)

Dispersion analysis

SAXS analysis

ARES-G2, TA Instruments

Bruker Discover D8 equipped

with LynxEye detector

TABLE 1.2.- Characterization techniques employed

\section{ASTM D6226}




\section{Scientific Objectives:}

- Evaluating in detail the effect of the dispersion quality of the clays in the polyol blend on the structure and properties of polyurethane foams filled with nanoclays.

- Evaluating in detail the effect of clays content on the cellular structure, thermal and mechanical properties of polyurethane foamed nanocomposites.

- Improving the thermal conductivity of polyurethane foams by using nanoclays as nucleating agents and IR-blockers.

- Modelling the thermal conductivity of the developed foams, using as a basis a detailed characterisation of the cellular structure and the experimental determination of the extinction coefficient of the foams.

\section{3.- Contents}

The manuscript has been divided into six different chapters:

1. Introduction: it is the present chapter. The motivation of this research work together with the objectives, the structure of the thesis, publications from the thesis and presentations are presented.

2. Background and state of the art: basic concepts on polyurethane foams and nanoclays and a detailed review of the state of the art of foamed polyurethane nanocomposites filled with nanoclays are presented.

3. Materials and characterization techniques: the polyurethane formulations and nanoclays employed, together with the methods to disperse the particles and produce the foams are described. The characterization techniques employed are also presented.

4. Influence of the formulation and dispersion technique used: different dispersion techniques are characterised over different polyurethane blends, with the objective of selecting the most sensitive formulation to these different techniques. With the selected formulation polyurethane foams with different dispersion qualities of the particles have been produced and characterised in detail. The influence of the dispersion quality on the structure and properties are discussed. 
5. Influence of nanoclays concentration: The previously selected formulation was employed for a complete study of the effect of the nanoclays concentration over the structure and foams properties, including effects on both mechanical properties and thermal conductivity. In addition the modelling of the thermal conductivity of PU foams containing clays is discussed.

6. Conclusions: the final conclusions obtained from this research are presented, together with the different projects in which the generated knowledge has been employed. Furthermore, possible future research topics are proposed.

\section{4.- Publications and presentations in conferences}

During the development of the present work the next presentations in conferences were produced:

M.A. Rodriguez-Perez, J. Pinto, J. Escudero, A. Lopez-Gil, E. Solorzano, C. Saiz-Arroyo, S. Estravis, S. Pardo-Alonso, Nano-strategies applied to the production of cellular polymers with improved cellular structure and properties. CellMat Conference, Dresden, Germany, 2012. (Talk)

S. Estravis, M.A. Rodriguez-Perez, Polyurethane foam composites: relationship between mechanical properties and filler matrix chemical interaction, SPE Eurotec Conference, Barcelona, Spain, 2011. (Talk)

S. Pardo, S. Estravís, E. Solórzano, M.A. Rodríguez-Pérez, J.A. de Saja, Effect of nanoadditves in rigid polyurethane foam nucleation monitored by $X$-ray radioscopy, SPE Eurotec Conference, Barcelona, Spain, 2011. (Talk)

S. Estravis, M.A. Rodriguez-Perez, Modification of the mechanical properties of polyurethane composites by using wastes of flexible polyurethane and sawdust as additives, FOAMS 2010, Seattle, EEUU, 2010. (Poster)

P. Álvarez, A. Echeverría, M.M. Petite, M.A. Rodríguez-Pérez, J. Pinto, S. Estravis, M.A. Martines, J. Abenojar, Fabrication, characterization and modeling of sandwich panels with polyethylene and polyurethane foams cores and aluminum skins, Comatcomp 09, San Sebastián, Spain, 2009. (Poster)

M.A. Martínez, J. Abenojar, M.A. Rodríguez-Pérez, J. Pinto, S. Estravis, J. Ecenero, E. Aldanondo, P. Álvarez, Polyolefin and polyurethane foam-aluminum joins: adhesion tests and modeling, $\mathbf{X}$ Congreso de Adhesión y Adhesivos, Alicante, Spain, 2009. (Poster)

S. Estravis, J.A. de Saja, R. Verdejo, M.M. Bernal, M.A. Rodríguez-Pérez, Improving the mechanical properties of rigid PU foams using nanofillers, XI Reunión del GEP, Valladolid, Spain, 2009. (Poster)

In addition, the next publications have been published or are close to be published: 
S. Pardo-Alonso, E. Solórzano, S. Estravis, M.A. Rodriguez-Perez, J.A. de Saja, In-situ Evidences of Nanoparticles Nucleating effect in Polyurethane-Nanoclay Foamed Systems, Soft Matter (2012) 8, 11262. DOI: 10.1039/C2SM259983D.

M. Bernal, I. Molenberg, S. Estravis, M.A. Rodriguez-Perez, I. Huynen, M.A. Lopez-Manchado,

R. Verdejo, Comparing the effect of carbon-based nanofillers on the physical properties of flexible polyurethane foams, Journal of Material Science (2012) 47 (15) 5673-5679.

S. Estravís, M. A. Rodríguez-Pérez , J. Tirado, S. Pardo-Alonso; Rigid polyurethane foams with infused nanoclays: relationship between cellular structure and thermal conductivity, Journal of Polymer Science, 2014. (Submitted)

R. Van Hooghten, S. Gyssels, S. Estravis, M.A. Rodriguez-Perez, P. Moldenaers, Understanding the effect of particle free energy on the structural and mechanical properties of clay-laden rigid PU foams, European Polymer Journal, 2014 (Submitted)

S. Estravís, R. Van Hooghten, M. A. Rodríguez-Pérez, R. Cardinaels, P. Moldenaers and J. Vermant; Effect of dispersion quality on the structure and properties of polyurethane foams infused with clays. (in preparation)

S. Estravís, R. Van Hooghten, M. A. Rodríguez-Pérez, R. Cardinaels, P. Moldenaers and J. Vermant; Effect of nanoparticles concentration on the structure and properties of polyurethane foams infused with nanoclays. (in preparation)

\section{5.- Applicability of the obtained results in industrial processes}

The knowledge generated in the present work has been employed to successfully conclude the next projects with private partners:

- Polyurethane foams for the production of surf boards. Foam Asturblank (2009-2010)

- Use of sepiolite nanoparticles to optimize the structure and properties of PS and PU based foams. TOLSA S.A. (2012-2013)

- Development of novel polyurethane foams with improved thermal insulation. BSH-group (Bosch and Siemens Home appliances Group) (2012-2013).

Some additional information about these projects is induced in the conclusions of this PhD thesis. 
${ }^{1}$ M.A. Rodríguez-Pérez, Propiedades Térmicas y Mecánicas de Espumas de Poliolefinas, Thesis, University of Valladolid, (1999)

${ }^{2}$ O. Almanza, Caracterización y Modelización de las Propiedades Térmicas y Mecánicas en Espumas de Poliolefinas, Thesis, University of Valladolid, (2000)

3 L.O. Arcos y Rábago, Propiedades Térmicas y Mecánicas de Espumas de Poliolefinas Fabricadas en un Proceso de Moldeo por Compresión, Thesis, University of Valladolid, (2002)

4 J.L. Ruiz-Herrero, Impacto y Fluencia de Espumas con Base Polietileno, Thesis, University of Valladolid, (2004)

5 J.I. González-Peña, Efecto de los Tratamientos Térmicos en Bloques de Espuma de Polietileno de Baja Densidad Producidos Mediante Moldeo por Compresión, Thesis, University of Valladolid, (2006)

${ }^{6}$ M. Álvarez-Laínez, Propiedades Térmicas, Mecánicas y Acústicas de Espumas de Poliolefina de Celda Abierta, Thesis, University of Valladolid, (2007)

${ }^{7}$ J. A. Reglero Ruiz, Fabricacion y Caracterización de espumas de aluminio: aplicaciones en el sector aeronáutico, Thesis, University of Valladolid, (2007)

${ }^{8}$ E. Solórzano, Aluminum foams: Foaming process, cellular structure \& properties, Thesis, University of Valladolid, (2008)

${ }^{9}$ F. Hidalgo-González, Diseño Optimizado de los Parámetros de Proceso de Fabricación de Espuma de Poliolefina Reticulada mediante Moldeo por Compresión, Thesis, University of Valladolid, (2008)

${ }^{10}$ S. Román-Lorza, Fabrication and characterization of flame retardant halogen free polyolefin based cellular materials, Thesis, University of Valladolid, (2010)

11 R. Campo-Arnáiz, Aplicación de Técnicas Espectroscópicas al Estudio de la Morfología Polimérica, Propiedades Térmicas y de Emisión de Espumas de Baja Densidad con Base Poliolefina, Thesis, University of Valladolid, (2011)

${ }^{12}$ C. Saiz Arroyo, Fabricación de materiales celulares mejorados basados en poliolefinas. Relación procesado-composición-estructura-propiedades, Thesis, University of Valladolid, (2012)

${ }^{13} \mathrm{~J}$. Lobos Martín, Improving the stiffness and strength of porous materials by enhancement of the matrix microstructure and cellular morphology, Thesis, University of Valladolid, (2013)

${ }^{14} \mathrm{http}: / /$ polyurethane.americanchemistry.com/

${ }^{15}$ Polyurethane (PU) Foams Market by Types (Rigid \& Flexible), End-User Industries (Bedding \& Furniture, Building \& Construction, Electronics, Automotives, Footwear, Packaging, \& Others), \& Geography (North America, West Europe, Asia-Pacific \& Row) - Global Trends \& Forecasts to 2018, http://www.marketsandmarkets.com/Market-Reports/polyurethane-foams-market1251.html

${ }^{16}$ L. J. Lee, C. Zeng, X. Cao, X. Han, J. Shen, G. Xu, Polymer nanocomposite foams, Composites Science and Technology, 65(15-16), 2344-2363, (2005) 
17 S. Pavlidou, C.D. Papaspyrides, A review on polymer-layered silicate nanocomposites, Progress in Polymer Science, 33, 1119-1198, (2008)

${ }^{18}$ R. Verdejo, C. Saiz-Arroyo, J. Carretero-Gonzalez, F. Barroso-Bujans, M.A. Rodriguez-Perez, M.A. Lopez-Manchado, Physical properties of silicone foams filled with carbon nanotubes and functionalized graphene sheets, European Polymer Journal, 44, 2790-2797 (2008)

${ }^{19}$ J.I. Velasco, M. Ardanuy, V. Realinho, M.Antunes, A.I. Fernández, J.I. González-Peña, M.A. Rodríguez-Pérez, J.A. de Saja, Polypropylene/clay nanocomposites: combined effects of clay treatment and compatibilizer polymers on the structure and properties, Journal of Applied Polymer Science, 102, 1213-1223 (2006)

20 J. Weiss, P. Takhistov, D.J. McClements, Functional materials in food nanotechnology, Journal of Food Science, 71(9), R107-R116, (2006)

${ }^{21}$ Q. H. Zeng, A. B. Yu, G. Q. Lu, D. R. Paul, Clay-based polymer nanocomposites: research and commercial development, Journal of nanoscience and nanotechnology, 5(10), 1574-1592, (2005)

${ }^{22}$ M. Modesti, A. Lorenzetti, S. Besco, D. Hrelja, S. Semenzato, R. Bertani, R.A. Michelin, Synergism between flame retardant and modified layered silicate on thermal stability and fire behaviour of polyurethane nanocomposite foams, Polymer Degradation and Stability, 93, 2166-2171, (2008)

${ }^{23}$ H. A.Patel, R. S. Somani, H. C. Bajaj, R. V. Jasra, Nanoclays for polymer nanocomposites, paints, inks, greases and cosmetics formulations, drug delivery vehicle and waste water treatment, Bulletin of Materials Science, 29(2), 133-145, (2006)

${ }^{24}$ D. Shah, P. Maiti, D. D. Jiang, C. A. Batt, E. P. Giannelis, Effect of nanoparticle mobility on toughness of polymer nanocomposites, Advanced Materials, 17(5), 525-528, (2005)

${ }^{25}$ T. Kashiwagi, F. Du, J. F. Douglas, K. I. Winey, R. H. Harris, J. R. Shields, Nanoparticle networks reduce the flammability of polymer nanocomposites, Nature Materials, 4(12), 928-933, (2005)

${ }^{26}$ X. Cao, L. J. Lee, T. Widya and C. Macosko, Polyurethane/clay nanocomposites foams: processing, structure and properties, Polymer, 46, 775-783, (2005)

${ }^{27}$ T. Widya, C. W. Macosko, Nanoclay-modified rigid polyurethane foam, J. of Macrom. Sci., Part B: Phys., 44(6), 897-908, (2005) 

CHAPIER 2:

BACKG ROUND AND STATE OF THE ART 



\section{BACKGROUND AND STATE OF THE ART}

\subsection{Cellular materials}

\subsubsection{Description, advantages and types}

A polymeric cellular material is a two-phase structure. One of them (gas phase) has been produced by a physical or chemical blowing agent and has been dispersed throughout the solid phase (polymeric matrix) ${ }^{1}$ which is the second phase. Although a foamed material is a kind of cellular material in which the cellular structure was created in the liquid state, in the development of this work both expressions, cellular polymer and foam will be used to refer to polymeric cellular materials.

The simplest cellular material that can be considered is a bi-dimensional network formed by polygons, with a structure that allows filling a plane. Fig. 2.1 shows an example, a honeycomb panel.

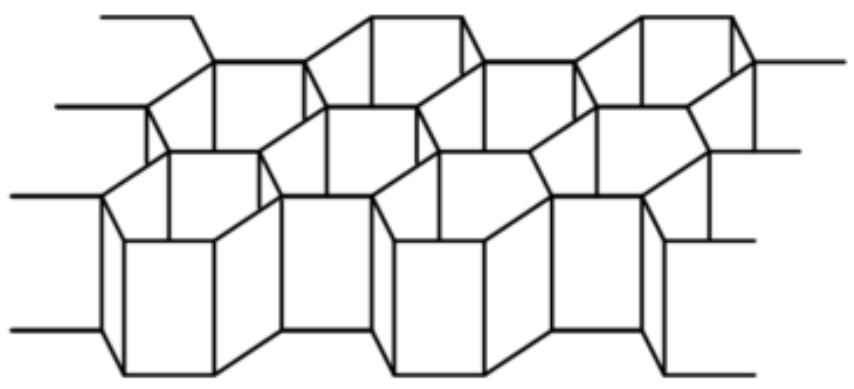

FIGURE 2.1 Honeycomb panel

However, usually cellular materials are composed by cells, with polyhedral shape, that fill the three dimensional space (Fig. 2.2).

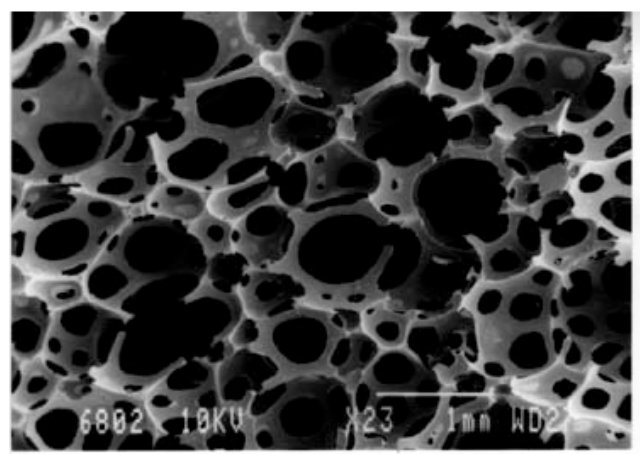

(a)

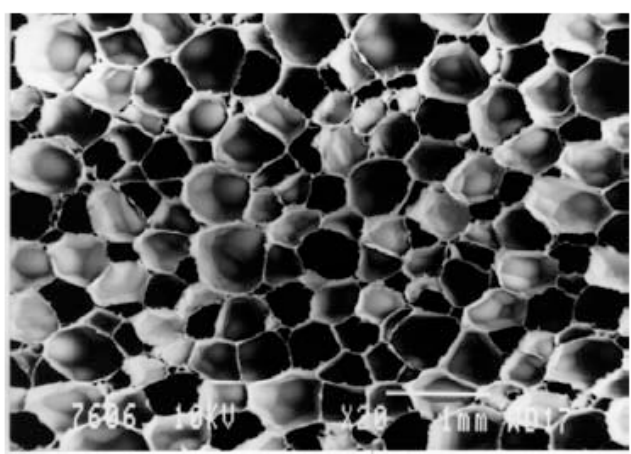

(b)

FIGURE 2.2. Three dimensional cellular structures: (a) Open cell structure, (b) closed cell structure 
Compared with solid materials, foamed materials extend widely the range of use, as can be seen in Fig. 2.3. The solid bars present the properties of the solid materials, while the dotted bars present the foamed materials properties. The wider range of foamed materials allows creating applications for foams which solid materials are not able to cover. Taking into account the properties showed in Fig. 2.3, these are some of the key advantages of cellular materials:

- Density: The decrease of the final material density allows the design of light, stiff components such as sandwich panels and floatation devices of all sorts.

- Thermal conductivity: foamed materials present lower thermal conductivity, which allows cheaper, eco-friendly thermal insulation.

- Stiffness: the stiffness reduction makes foams ideal for a wide range of cushioning applications (mattress and seating industries) in which elastomeric foams are the standard materials.

- Strength and compressive strains: the low strengths and large compressive strains make foams attractive for energy-absorbing applications, occupying these materials a fundamental role in the shipping and packaging industries.
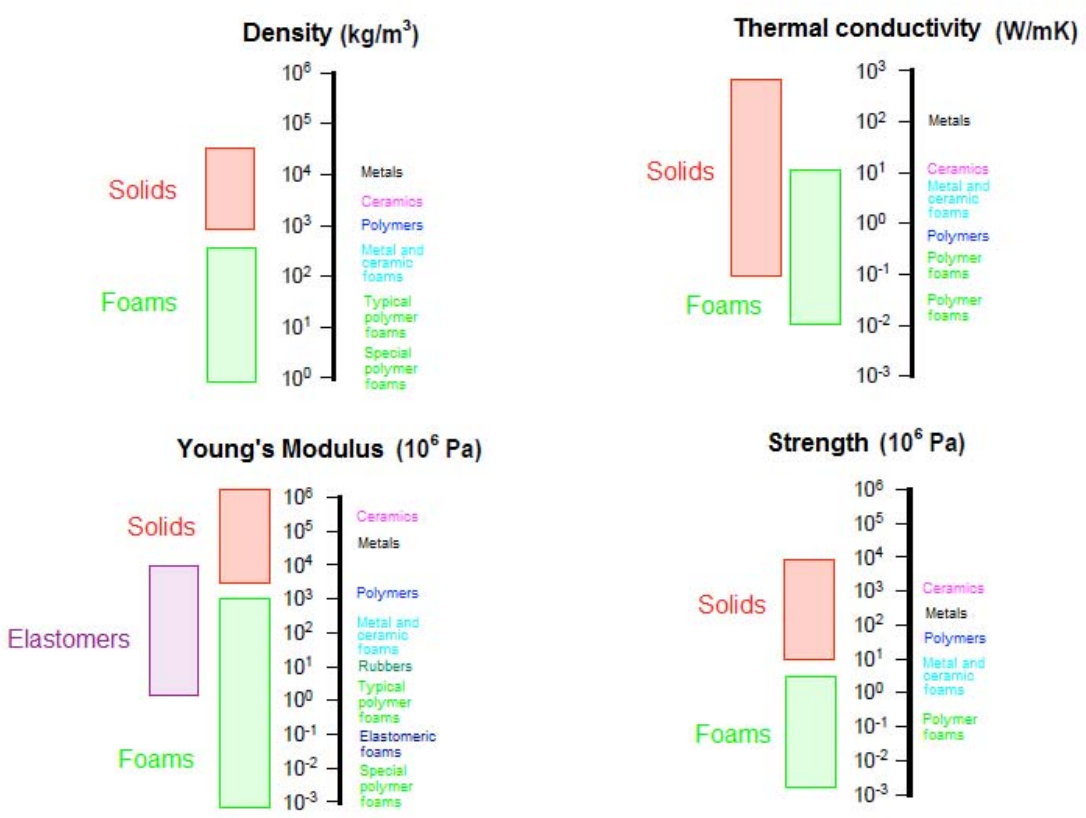

FIGURE 2.3.- Foam vs. solid materials properties: (a) density; (b) thermal conductivity; (c) Young's modulus; (c) compressive strength. 
Cellular materials can be classified using different criteria. A first classification can be made referring to the cellular structure and the connectivity of the cells: the structure can be open or closed, i.e. the gas volume forms a continuous phase (open cell structure, Fig. 2.1.1.2.a) or a discontinuous phase (closed cell structure, Fig. 2.1.1.2.b). Normally, it is easy to find materials with an intermediate structure: fraction of the volume is formed by an open cell structure while other fraction of the volume is formed by a closed cell structure ${ }^{1}$.

Other classification of cellular materials can be made attending to their density, which highly determines the final properties, and consequently the final applications ${ }^{1,2}$. In foamed materials it is usual to employ the parameter "relative density" ( $\rho_{\text {relative }}$, Eq. 1$)$, which is the relationship between the foam density $\left(\rho_{\text {foam }}\right)$ and the solid material density $\left(\rho_{\text {solid }}\right)^{1}$.

$$
\rho_{\text {relative }}=\rho_{\text {foam }} / \rho_{\text {solid }}
$$

According to their relative density, cellular solids can be classified in three different groupsiError! Marcador no definido.:

- Low density cellular materials: relative density lower than 0.3 .

- Medium density cellular materials: relative density between 0.3 and 0.6 .

- High density cellular materials: relative density higher than 0.6.

The density of rigid polyurethane foams ranges between 10 and $1100 \mathrm{~kg} / \mathrm{m}^{3}$, but the most common densities both in industry and research ranges from 28 to $50 \mathrm{~kg} / \mathrm{m}^{3}$, i.e. relative density between 0.025 and 0.045 . According to the previous classification these can be considered low density cellular materials.

\subsubsection{Cellular structure}

The characteristics of the cellular structure play a key role on the final properties. Due to this we briefly explain these characteristics in the following paragraphs:

- Mean cell size: it is referred to the mean cell size of the cells that forms the cellular material. The most common method for measuring this property is presented in ASTM D3576 standard, based on the Intersections Method ${ }^{4}$. In this work, an specific script developed on CellMat Laboratory has been employed, based on Open Source Software Image $J^{5}$. With this software, it was possible to measure, together with the cell size, some cellular 
parameter as the cellular density (i.e. number of cell per volume unit) or the anisotropy ratio.

Influence of the cell size over thermal properties is a well-known effect: the reduction of the cell size implies a reduction of the thermal conductivity for closed cell foams, due to a reduction of the radiation term implied in the thermal conductivity. This effect is observed for relative densities lower than 0.15 .

Mechanical properties for low strains do not present a clear relationship with cell size: studies for similar densities and different cell sizes have not shown dependence between cell size and mechanical properties ${ }^{6-8}$ at low strains (i.e. stiffness and strength)

- $\quad$ Cell size distribution: Although cell size has not a clear influence over the mechanical properties at low strains, cell size distribution effect over these properties is well-known: a non-uniform cell size distribution has a negative influence over the final properties of the material ${ }^{2,9-11}$. Tipically, a material with an inhomogeneous cell size distribution presents lower mechanical properties than a material with a homogeneous cell size distribution, due to a poor strain distribution in the entire volume ${ }^{1}$.
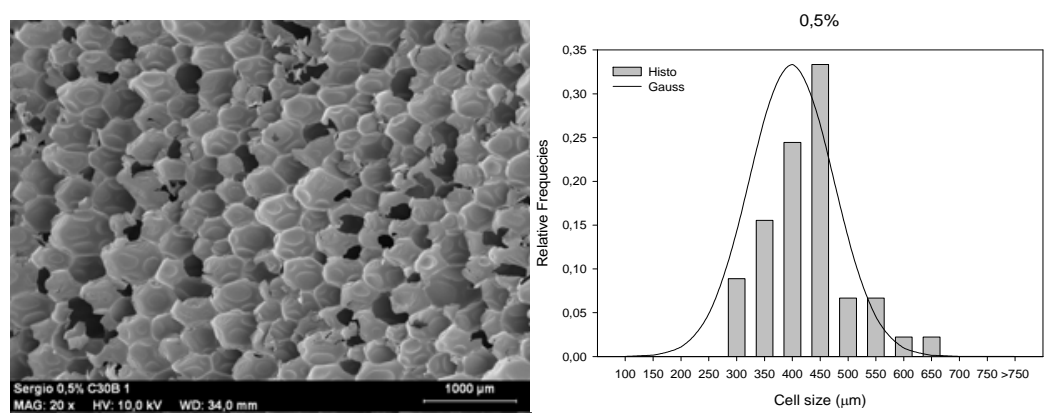

FIGURE 2.4.- SEM image and histogram

For the study of a certain sample the use of a cell size histogram (Fig. 2.4) could help to show what kind of cell size distribution is present in the material. But for the comparison between large amounts of samples it is easier to employ the standard deviation of the cell size distribution, defined in Eq. 2.2, which gives the width of the distribution ${ }^{12,13}$. 
Chapter 2: Background and State of the Art

$$
S D=\sqrt{\sum_{i=1}^{n} \frac{\left(\phi_{i}-\phi\right)^{2}}{n}}
$$

In this equation, $\mathrm{n}$ is the total number of cells, $\phi_{i}$ is the cell diameter of cell $i$ and $\phi$ is the average cell size. A cell size distribution is more homogeneous when the SD value decreases.

- Open cell content: Fig. 2.2 shows two extremes related with the cellular morphology of cellular materials: completely open cell and completely closed cell. But other intermediate states are possible. The open cell content can be defined as ${ }^{9}$ :

$$
\text { OC }(\%)=\frac{\text { Interconected cells volume }}{\text { Total gas volume }}
$$

It can be determined with an air or gas pycnometer following the standard ASTM D6226 $6^{14}$.

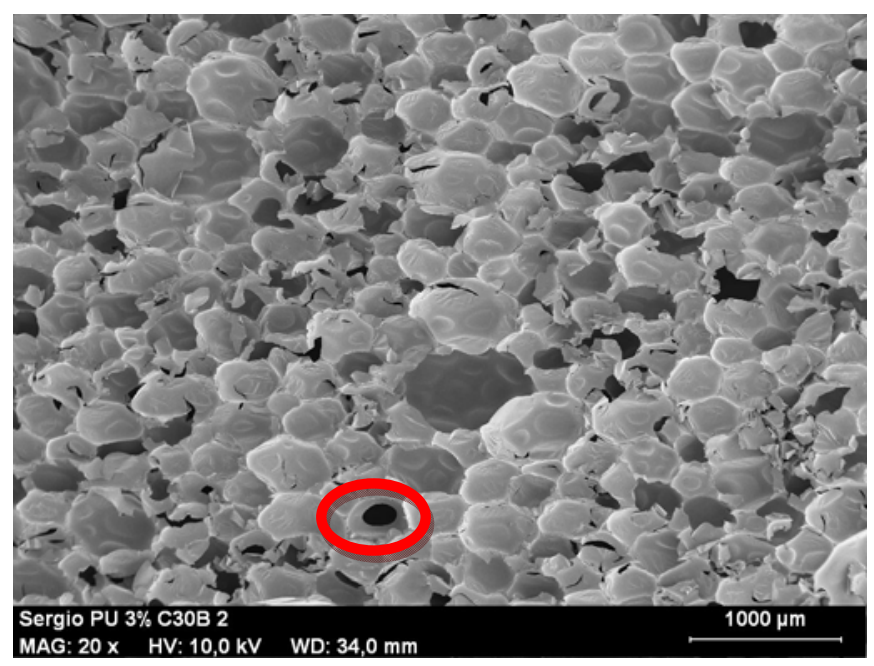

FIGURE 2.5.- Micrograph showing interconnection of cells for rigid PU foam

Open cell presence in cellular materials is positive for certain applications: sound waves absorption, seating industry or filters. However, from the mechanical and thermal insulation point of view, a certain grade of cellular interconnection can suppose a drawback. Figure 2.5 shows the interconnection of cells that is produced in rigid polyurethane foams.

- Anisotropy: Some cellular materials present anisotropy, both in orientation of the cellular structure (Fig 2.6) and in their properties ${ }^{11}$. 

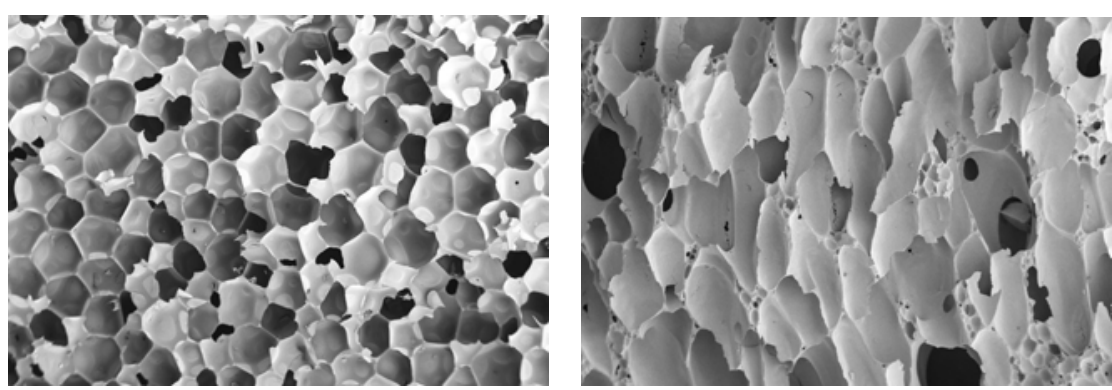

FIGURE 2.6. Micrographs of isotropic (left) and anisotropic (right) pores.

In those materials with a principal growing direction, it is possible to define the Anisotropy Ratio ( $R$, Eq. 2.4) as the quotient between the average diameter of the cell in the growing direction and the diameter in the perpendicular direction ${ }^{1}$.

$$
R=\frac{\phi_{z}}{\left(\frac{\phi_{x}+\phi_{y}}{2}\right)}
$$

The orientation in the cellular structure usually implies an orientation in the properties of the foams ${ }^{1,11}$. This effect presents benefits in some structural applications, with better properties in the preference orientation direction with respect to the isotropic material. But for thermal insulating it has a negative effect: the material presents higher thermal conductivity in the direction of cellular orientation ${ }^{15}$.

- Fraction of material in the struts $\left(f_{s}\right)$ : the solid phase in cellular materials is distributed between the components of cells: these are basically walls, struts (also called plateau borders) and vertexes (or triple points). On Figure 2.7 it is possible to observe an idealization of a 3D single cell, in which vertexes can be considered as an extension of struts since they are actually the junctions of these microstructures both components. Hence, solid phase can be considered a combination of walls and struts. It is well known that presence/absence of walls (closed/open cell) is a determinant factor for the physical behavior of the materials regarding mechanical, thermal, electrical or acoustic properties ${ }^{1}$. 


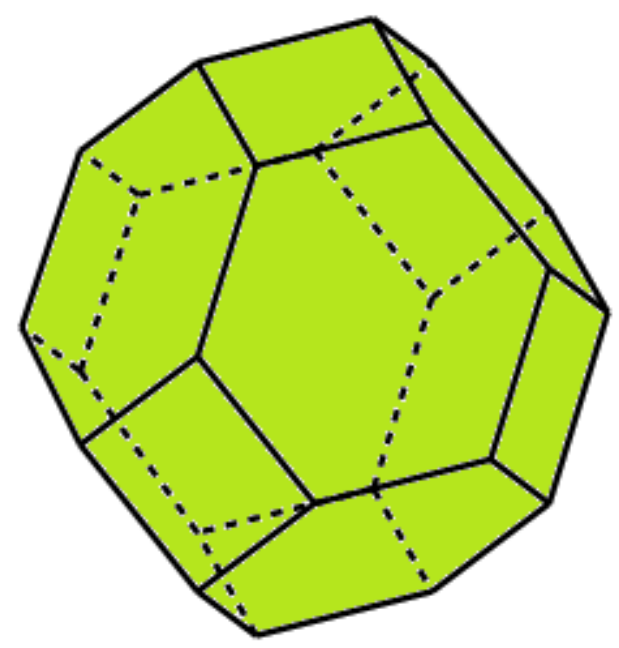

FIGURE 2.7.- Kelvin model of a single cell: coloured parts represents cell walls, while black lines represents the struts.

Furthermore the strut volume fraction $\left(f_{s}\right)$ allows considering intermediate situations, taking into account the presence or the absence of walls. Equation 2.5 shows the definition of fraction of materials in the struts as the ration between of the amount of material contained in the struts and the material in the whole foam (struts + walls).

$$
f_{s}=\frac{\text { struts mass }}{\text { struts }+ \text { walls mass }}
$$

For open cell foams this parameter takes a value of 1 , taking lower values for closed and not completely open cell foams.

\subsubsection{Estimation of mechanical properties of cellular materials}

Due to the close relationship between density and properties, it is possible to have an initial estimation of the foams properties by using the value of density, properties of the solid matrix and the scaling relations ${ }^{1,16}$. These empiric equations (Eq. 2.3) show how the foams properties $\left(P_{\text {foam }}\right)$ are related to the solid material property $\left(P_{\text {solid }}\right)$, the relative density of the foam $\left(\rho_{\text {foam }}\right)$ and the density of the solid matrix $\left(\rho_{\text {solid }}\right)$ Two additional parameters $(C$ and $n$ ) are used in this equation. These values can be obtained by fitting experimental values to the scaling relationships: 


$$
P_{\text {foam }}=C \cdot P_{\text {solid }} \cdot\left(\rho_{\text {foam }} / \rho_{\text {solid }}\right)^{n}
$$

The $C$ value is generally close to 1 , (for high densities). The $n$ value typically ranges between 1 and 2, and it is close related with the property under study and the key characteristics of the cellular structure ${ }^{1,16}$.

Relative properties for cellular materials are defined as the ratio between that of the foamed material and the same property for the solid material (eq. 2.7). Fig. 2.8 shows the relative properties-relative density relationship. It is possible to observe a linear relationship between density and material properties when $n=1$, however, as $n$ value increases, the value of the property is reduced for a given density.

$$
P_{\text {rel }}=\frac{P_{\text {foam }}}{P_{\text {solid }}}
$$

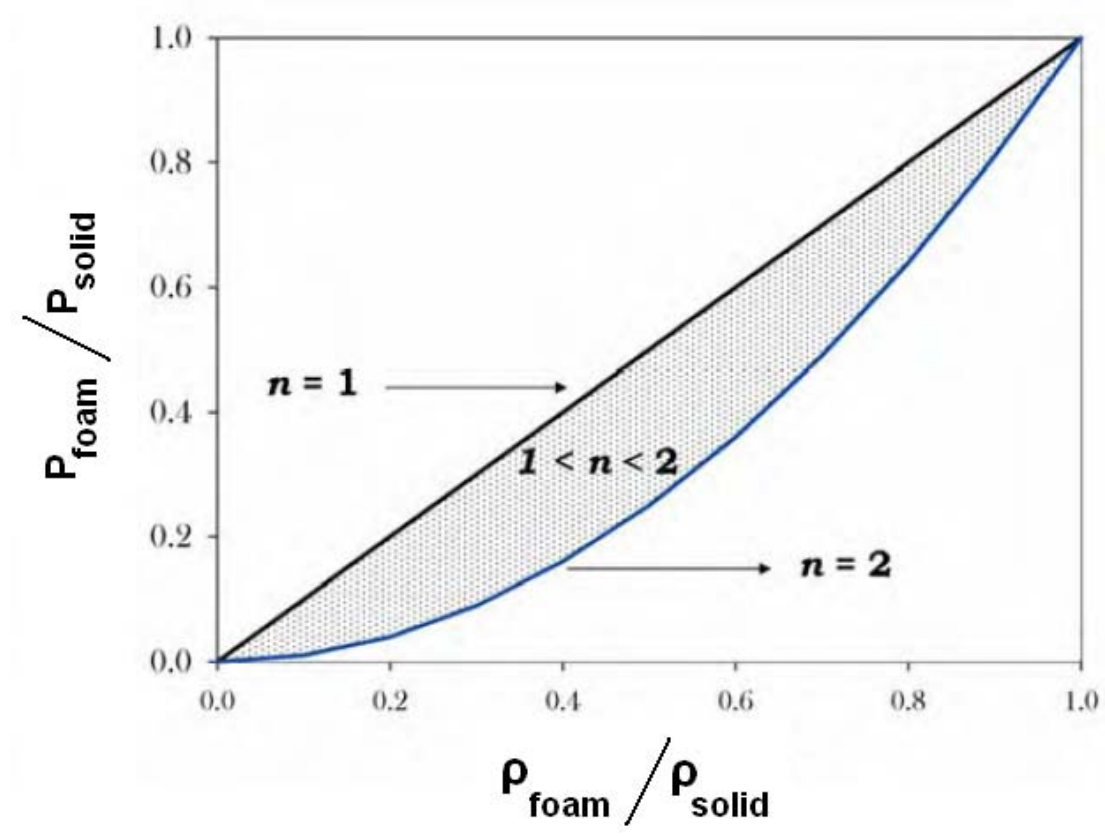

FIGURE 2.8.- Relative properties vs. relative density for cellular materials

The vast majority of cellular materials present, for their main properties, an $n$-value higher than 1, which implies a non-lineal relationship between relative properties and density. For structural applications (in which typically it is necessary to improve stiffness and strength), where the lowest properties reduction is desired, an n-value closer to 1 is needed. Analysing the elastic modulus and the collapse strength, some studies show that for isotropic foams 
lower $n$-values are obtained for closed cell structures with good cellular size homogeneity (low values of SD, Eq 2.2; i.e. very homogenous cell size distributions) ${ }^{17}$. For other properties as the impact strength, toughness or fatigue behaviour, it has been also proved that lower n-values are obtained for microcellular structures (cell sizes lower than $10 \mu \mathrm{m})^{10,11,18}$

\subsubsection{Thermal conductivity of cellular materials}

Among the thermal properties of cellular materials, thermal conductivity plays a fundamental role in the foams world, as thermal insulation is one of the main commercial applications of cellular materials.

The presence of two different phases on cellular materials makes impossible the measurement of the thermal properties at microscopic scale, forcing to understand the properties as a global, macroscopic property. Anyway, a theoretical approximation is possible: individual properties of each phase (solid and gas) can be employed for the estimation of the macroscopic conductivity. This is one of the most interesting problems and one of the most studied topics in the polymeric foams field ${ }^{15,19-21}$.

Four mechanisms are involved in the thermal conductivity of cellular materials: conduction along the cell walls and the struts of the solid polymer $\left(\lambda^{s}\right)$, conduction through the gas phase $\left(\lambda^{g}\right)$, thermal radiation $\left(\lambda^{r}\right)$, and convection within the cells $\left(\lambda^{c}\right)$. The total heat flow $\left(\lambda^{t}\right)$ is a result of the four contributions and can be expressed by a superposition of each mechanism taken separately ${ }^{15,19,22-25}$.

$$
\lambda^{t}=\lambda^{s}+\lambda^{g}+\lambda^{r}+\lambda^{c}
$$

The convective heat transfer can be assumed to be negligible ${ }^{15,26}$ in the case of very small cell size (lower than 1-2 mm). The expression of gas and solid phase terms is shown in equations 5 and 6 , where $V_{g}$ is the volume fraction of the gas phase $\left(1-\rho_{\text {foam }} / \rho_{\text {solid }}\right), \lambda_{g}$ is the thermal conductivity of the gas enclosed in the cells at a given temperature, $V_{s}$ is the volume fraction of polymer $\left(\rho_{\text {foam }} / \rho_{\text {solid }}\right), \lambda_{s}$ is the thermal conductivity of the solid polymer and fs is the mass fraction in the struts of the cellular structure ${ }^{27}$.

$$
\begin{gathered}
\lambda^{g}=\lambda_{g} V_{g} \\
\lambda^{s}=\left(\frac{2}{3}-\frac{f_{s}}{3}\right) \lambda_{s} V_{s}
\end{gathered}
$$


To calculate the radiation term, a simple approach is to estimate conductive terms of the gas and the solid using Eq. 2.9 and 2.10, and subtract them from the experimental value of the conductivity to obtain an "experimental" value of the thermal radiation term ${ }^{26}$. Anyhow a theoretical approximation is also possible. In practical applications, radiation travels only a short distance (mean free path) before being scattered or absorbed. The transferred energy depends only on the intermediate vicinity of the position being considered. This approximation is called diffusion approximation (in this process, the heat flux is proportional to the local gradient of the potential, in this case the black body emissive power $\sigma T^{4}$ ), and the radiative heat flux $q_{r}(x)$ can be expressed as follows ${ }^{28}$ :

$$
q_{r}(x)=\frac{4}{3 K_{e, R}} \frac{\partial e_{b}}{\partial x}=\frac{-16 \sigma T^{3}}{3 K_{e, R}} \frac{\partial T}{\partial x}=-\lambda_{r} \frac{\partial T}{\partial x}
$$

where $\lambda_{r}$ is the radiative thermal conductivity. Foams used in real applications are usually thick enough (several millimetres thick) to be considered optically thick; therefore, the radiative flux can be approximated by Rosseland equation ${ }^{29}$ as follows:

$$
\lambda_{r}=\frac{16 n^{2} \sigma T^{3}}{3 K_{e, R}}
$$

In this equation $n$ is the effective refraction index and $K_{e, R}$ is the Rosseland mean extinction coefficient. For polymer foams, $n$ is close to on ${ }^{30}$; this approximation will be valid in this study because the foams under analysis have a volume of gas (porosity) higher than $95 \%$. The determination of the extinction coefficient using the Beer-Lambert law is explained in section 3.2.6.

\subsection{Water Blown Rigid Polyurethane Foams}

\subsubsection{Chemistry of polyurethane}

The origin of polyurethane foams can be situated in Leverkusesn, were Otto Bayer and coworkers produced in 1937 the first polyurethane foam. The first commercial product was introduced in 1950. Nowadays polyurethane foams are one of the most important materials in the polymeric industry, with multiple uses in several industries as automotive, sports equipment, furniture, construction, and much more. But the "word" polyurethane described a significant amount of different materials, including rigid or flexible foams, elastomers, adhesives, etc. Usually, the term polyurethane is used to refer the polyaddition of a 
polyisocianate with a polyol to form a heterogeneous copolymer. As a result of this reaction, urethane linkages between the polymeric chains are produced (Fig. 2.9).

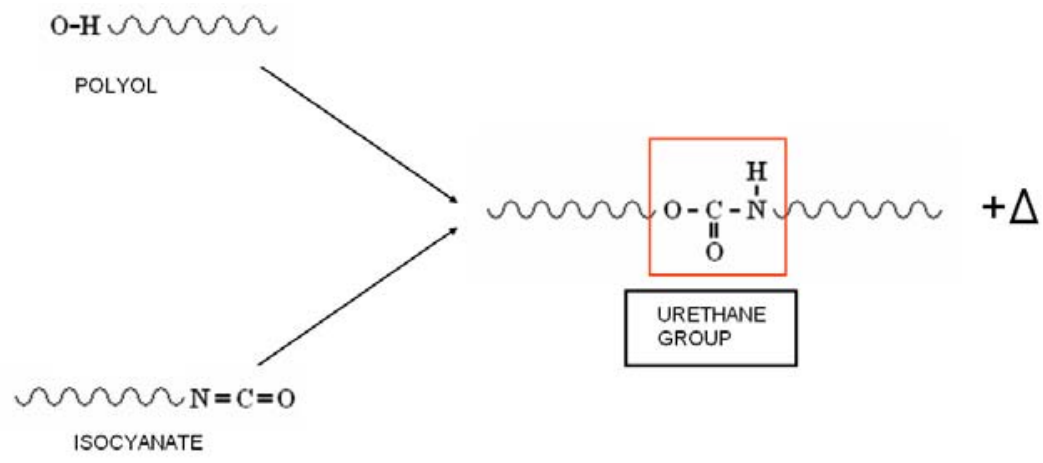

FIGURE 2.9.- Urethane bond formation

The type of polyol and isocyanate and their ratio, the presence of catalysts, surfactants and so on, and the reaction conditions have a strong influence on the properties of the resulting polyurethane. Long, flexible segments presents in the polyol have as a result the production of an elastic polymer (Fig. 2.10.a), characterized by phase separation between amorphous urea rigid segments and flexible polyol segments ${ }^{31}$. On the other hand, rigid foams are the result of a high degree of cross linking between short polymeric chains (Fig. 2.10.b).

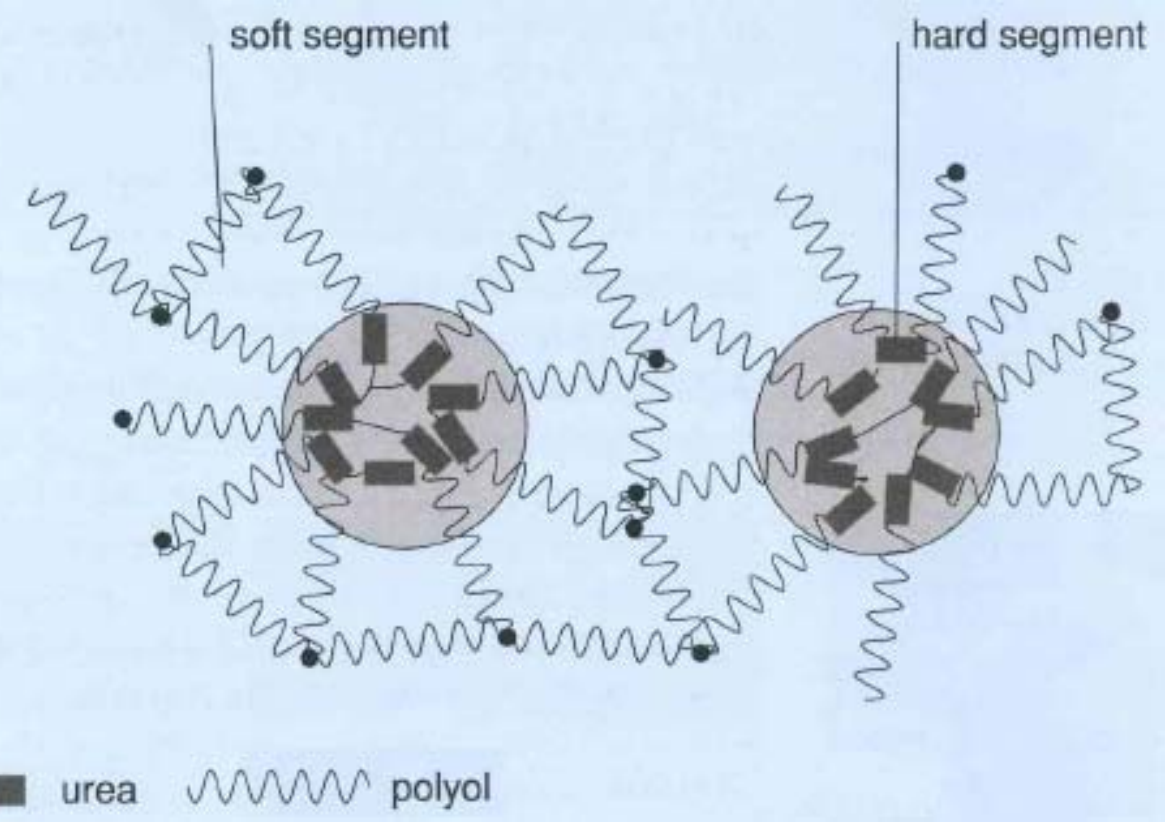


b.-

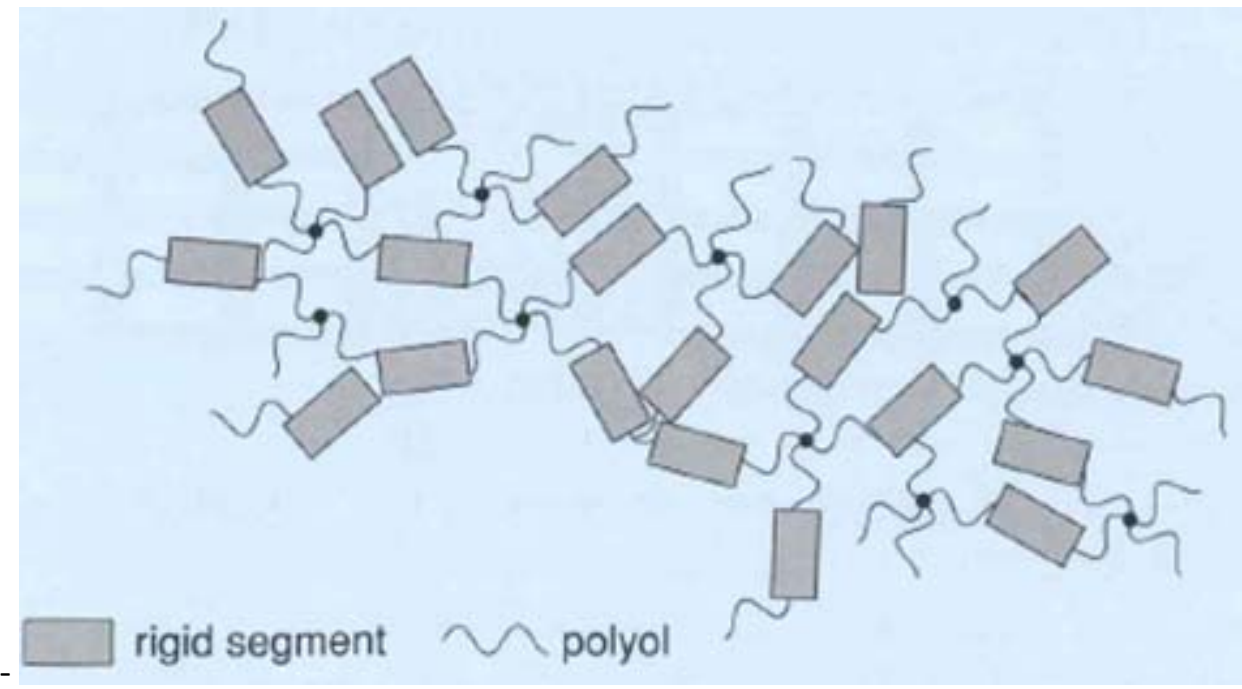

FIGURE 2.10. Schematic drawing of polyurethane structure in a: a.) Flexible polyurethane foam, b.) Rigid Polyurethane foam ${ }^{31}$

Two main reactions can be considered in water-blown rigid polyurethane foams, polymerization reaction and water blowing reaction. Polymerization reaction, also sometimes called gelation reaction, has been previously described (Fig. 2.5); this reaction produces the urethane linkages that characterize the polyurethane. The heat of this reaction is reported to be approximately $101 \mathrm{KJ} / \mathrm{mol}$ of urethane formed ${ }^{32}$. This reaction is usually characterized by the $\mathrm{OH} / \mathrm{NCO}$ molar ratio, which shows the excess or default of one of the reagents. The desired $\mathrm{OH} / \mathrm{NCO}$ molar ratio satisfies the equation ${ }^{33}$ :

$$
M_{\text {ratio }}=\frac{W_{\text {polyol }} / E W_{\text {polyol }}}{\left(W_{P U}-W_{\text {polyol }}\right) / E W_{\text {isocyanate }}}
$$

where $W_{\text {polyol }}$ is the weight of the polyol, $E W_{\text {polyol }}$ is the equivalent weight of polyol, $W_{P U}$ is the total weight of $\mathrm{PU}$ to be produced and $E W_{\text {isocyanate }}$ is the equivalent weight of the isocyanate. The equivalent weight of the isocyanate is usually provided by the supplier. The equivalent weight of polyol (in grams per mole of hydroxyl groups) can be determined using the equation:

$$
E W_{\text {polyol }}=\frac{\text { molecular weight of } \mathrm{KOH} \times 1000}{\text { OH Number }}=\frac{56110}{\mathrm{OH} \mathrm{Number}}
$$

$\mathrm{OH}$ number is an index that allows polyols classification by their molecular weight, and which is described in the polyurethane components section. 

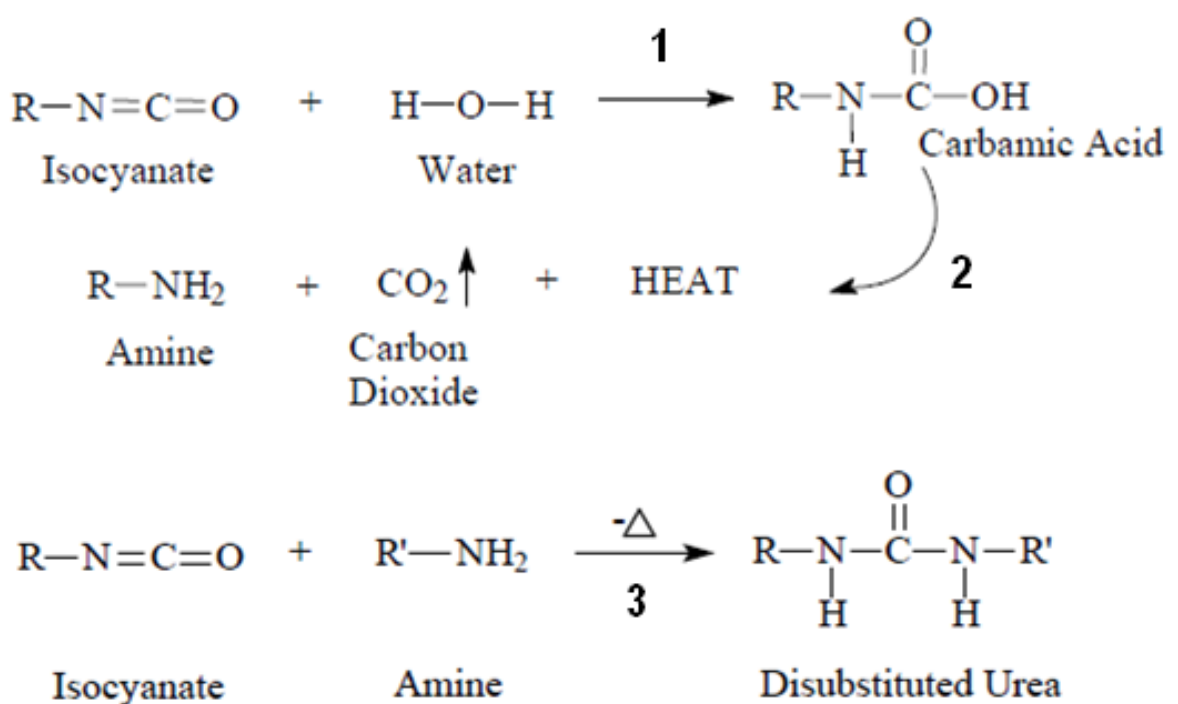

FIGURE 2.11.- 3 step water-isocyanate reaction

Water blowing reaction is described in Fig. 2.11, where three different steps can be observed $^{34}$. In the first step, water and isocyanate react to produce carbamic acid. That is an instable sub-product that decomposes, in a second step, into an amine $\left(\mathrm{R}-\mathrm{NH}_{2}\right)$ and $\mathrm{CO}_{2}$, which acts as blowing agent. Finally, in a third step, amine reacts with another isocyanate group to produce urea, which is a stable product. This reaction is exothermic, with a value of 86 $\mathrm{KJ} / \mathrm{mol}^{35}$.

Although these reactions are the most characteristic of rigid, water blown polyurethane foams, other reactions are produced, like the isocyanurate reaction ${ }^{36}$ or biuret formation. As consequence of the disubstituted urea formation, biuret formation could be produced as it is shown on Fig. 2.12.<smiles>[R]N=C=[O+]</smiles><smiles>[R]NC(=O)N([R])C(=O)N[R]</smiles>

Biuret

FIGURE 2.12.- Biuret formation 


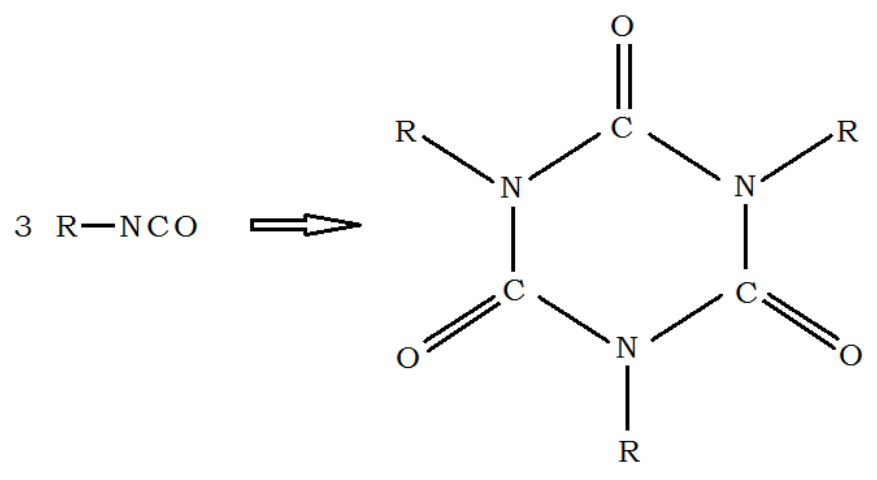

FIGURE 2.13.- Isocyanurate reaction

In the case of isocyanurate, three isocyanate molecules produce an isocyanurate ring (Fig. 2.13), which results in so-called isocyanurate foams with greater thermal stability, improved fire resistance and greater dimensional stability than simple polyurethane foams ${ }^{37}$, 38. Anyway, this kind of foams requires higher amounts of isocyanate, resulting in a more expensive product. Also, temperature increase due to isocyanurate heat reaction can produce fire hazard.

\subsubsection{Polyurethane components}

As previously discussed, polyurethane foams are the product of the polyol-isocyanate reaction. But there are other fundamental components that play a role in the production of polyurethane foams. The main components involved in the polyurethane production are described in the next paragraphs:

- Polyols: polyols are polymers on their own and have on average two or more hydroxyl groups per molecule. Most common polyols are a polyether and polyester mix. In the case of rigid polyurethane foams the polyols used have weights in of hundreds $\mathrm{g} / \mathrm{mol}$, while those used to make flexible polyurethane have molecular weights up to ten thousand and more $\mathrm{g} / \mathrm{mol}$. Polyols can be classified by functionality and molecular weight, which determines the rigid or flexible behaviour of the final foam. $\mathrm{KOH}$ index or hydroxyl index is a wellknown index that allows polyols classification by their molecular weight, as the $\mathrm{KOH}$ index is inversely proportional to the molecular weight ${ }^{31}$. It is defined as $\mathrm{KOH}$ mg needed to neutralize a polyol gram (ASTM D1957-86). The $\mathrm{KOH}$ index for a polyol with a molecular weight between 2000 and $10000 \mathrm{~g} / \mathrm{mol}$ is between 18 and 56, and will produce polyurethane flexible foams. On the 
other hand, for a molecular weight between 250 and $700 \mathrm{~g} / \mathrm{mol}$ the $\mathrm{KOH}$ index will be between 300 and $700 \mathrm{KOH} \mathrm{mg} \mathrm{/g}$, and rigid foams will be produced.

- Isocyanates are very reactive compounds, and different kinds are employed in the polyurethane manufacture. Some of them are diphenilmethane diisocyanate (MDI), toluene diisocyanate (TDI), hexamethylene diisocyanate (HDI) or isophorone diisocianate (IPDI). Most of them present exactly two isocyanate groups per molecule, but nowadays the employ of polymeric MDI isocyanate (PMDI) is widespread, which presents a mixture of molecules with more than two isocyanate groups. In polyurethane foams formulation, a critical parameter is the isocyanate index (Eq. 2.15), which is the percentage of isocyanate used regarding to the theoretical amount required (that can be calculated with the Eq. 13).

$$
\text { NCO index }=100 \times \frac{\text { Amount of isocyanate employed }}{\text { Theorical amount of isocyanate needed }}
$$

This value is fundamental, as it variations produce changes in the final chemical polyurethane composition, and, as consequence in the final material properties ${ }^{36,39}$. High values of NCO index will produce materials with higher amounts of isocyanurate ${ }^{36}$, while low NCO values are employed in flexible foams preparation ${ }^{40}$.

- Additives: additives are usually included in polyol component, due to its lower reactivity. Main additives employed are catalysts (for polymerization and/or blowing reaction), other additives (like particles and nanoparticles, with the aim to vary some properties) and surfactants (in order to control final cell size and/or final density). One of the most employed surfactants are silicone compounds, which can lower surface tension, emulsify incompatible formulation ingredients, promote generation of bubbles during mixing, and stabilize cell walls ${ }^{32}$. Among these functions, cell walls stabilization is the most important. During foaming, the bubbles initially introduced by mechanical mixing will grow. As the volume fraction of the gas bubbles exceeds $74 \%$, the spherical bubbles will distort into multisided polyhedrals and cell walls with Gibbs Plateau Borders are formed. Due to capillary pressure, pressure inside the plateau borders is lower than that in the cell walls. This pressure difference will cause liquid in the cell walls to drain into the struts. Without adding 
silicone surfactant, this drainage rate is very fast so that film ruptures and bubble coalescences occur rapidly.

- Chemical Blowing agents: The gas production in this kind of materials is tipically due to a chemical reaction between the foaming agent and one of the polyurethane reactives, usually isocyanate (Fig. 2.7). The most common chemical blowing agent is water ${ }^{41}$, which as it has been previously explained, reacts with isocyanate producing, over several consecutive reactions, $\mathrm{CO}_{2}$ and urea [Fig. 2.7]. The employ of water as blowing agent has experience a considerable growth in the last few years due to its ecological behaviour with ozone, in comparison with older ozone-depleting blowing agents ${ }^{42}$. But, it has some drawbacks, as the high temperatures produced and the need of increasing the amount of isocyanate employed ${ }^{43}$. These are critical points in low densities, especially under $50 \mathrm{~kg} / \mathrm{m}^{3}$ densities when insulating properties are sought. Moreover, although the thermal conductivity of $\mathrm{CO}_{2}$ is lower than the thermal conductivity of air, it diffusivity through the polymer matrix is higher, which implies a significant and rapid increase of thermal conductivity with time ${ }^{44}$ due to its substitution by atmospheric air with higher thermal conductivity. For these reasons, physical blowing agents are sometimes used together with water to produce polyurethane foams.

- Physical blowing agents are usually materials with low temperature boiling point, near to room temperature. The exothermic isocyanate-polyol reaction produces the vaporization of these materials. Some of them are 1,1,1,3,3pentafluorobutane ${ }^{17,}{ }^{41}, 1,1,1,2,3,3,3$-heptafluoropropane ${ }^{17}$ iError! Marcador no definido., cyclopentane $\mathrm{e}^{39,45,46}$, isopentante ${ }^{39,46}$, HCFH $141 \mathrm{~b}^{47}$. The 1987 Montreal Protocol set defined deadlines for certain compounds that were determined to have high ozone depleting potential (ODP). Chlorofluorocarbons (CFC)-based formulations, in the early 1990s, were converted to hydrochlorofluorocarbons (HCFC) with significantly lower ODP. HCFC blowing agents were also phased out by the Montreal protocol, requiring that all manufacturing be converted from HCFC's no later than January 1st, 2010. Accordingly, Dow Chemical has fully converted all its production of STYROFOAM ${ }^{\mathrm{TM}}$ insulation board products (polystyrene foams) from HCFC-142b to hydrofluorocarbons (HFC) or hydrocarbons (HC) and $\mathrm{CO}_{2}$ in $2009^{48}$. 
TABLE 2.1. Physical and environmental properties of different blowing agents.

Blowing agents characteristics

\begin{tabular}{cccccc}
\hline Compound & $\begin{array}{c}\text { Mw } \\
\text { g-mole }\end{array}$ & $\begin{array}{c}\text { Thermal } \\
\text { Conductivity } \\
\text { mW/m.K }\end{array}$ & $\begin{array}{c}\text { ODP } \\
(100 \text { yrs })\end{array}$ & $\begin{array}{c}\text { GWPit } \\
\text { limit } \\
\%\end{array}$ \\
\hline CFC-12 & 120.9 & 9.4 & 1 & 10900 & NF \\
HCFC-142b & 100.5 & 11.7 & 0.065 & 2310 & $7.8-15.5$ \\
HFC-134a & 102.0 & 13.5 & 0 & 1430 & NF \\
HFC-152a & 66.1 & 12.6 & 0 & 124 & $5-30$ \\
HFC-32 & 52.0 & 14.3 & 0 & 675 & $12.5-30$ \\
CO2 & 44.0 & 15.2 & 0 & 1 & NF \\
\hline NF: non flammable & & & &
\end{tabular}

Table $2.1^{49}$ shows some of the properties of the HFCs, which usability is also uncertain due to environmental issues. This table includes environmental values: Ozone Depletion Potential (ODP) and Global-warming potential (GWP). ODP can be estimated by the compound chemical structure, and GWP is a relative measure of how much heat a greenhouse gas traps in the atmosphere ${ }^{50}$. The U.S. market still uses high GWP blowing foaming agents, while the most of the rest of the world uses pentane isomers as foam blowing agents ${ }^{51}$ for polyurethane. Therefore, the use of HFC blowing agents for rigid polyurethane in the U.S. should be replaced with lower GWP alternatives. In fact, General Electric has recently started using cyclopentane for production of its top refrigerator-freezers ${ }^{52}$. Other options include R744 and HFO-1234ze $\mathrm{e}^{53}$, $\mathrm{HBA}-2^{54}$ and a liquid blowing agent AFA-L1 ${ }^{55}$. Hydrofluoroolefins (HFO's) are the latest generation of blowing agents; they have zero ODP but rather high GWP. Main characteristics are shown in Table $2.2^{56}$.

TABLE 2.2. Key HFO blowing agent properties

\begin{tabular}{|c|c|c|c|c|c|c|}
\hline & Mw & ODP & GWP & POCP & $\begin{array}{c}\text { Solubility } \\
(\mathrm{pph} / \mathrm{atm})\end{array}$ & $\begin{array}{c}\text { Diffusivity } \\
\left(\mathrm{cm}^{2} / \mathrm{sec}\right)\end{array}$ \\
\hline $\mathrm{CO} 2$ & 44 & 0 & 1 & 0 & 0.4 & $7.010^{-07}$ \\
\hline HFC-134a & 102 & 0 & 1430 & 0.1 & 2.3 & $9.3910^{-12}$ \\
\hline HFO-1261zf & 60 & 0 & $<5$ & na & 5.5 & $1.2510^{-11}$ \\
\hline HFO-1243zf & 96 & 0 & 3 & 10.7 & 2.1 & $3.6410^{-12}$ \\
\hline HFO-1234ze & 114 & 0 & 6 & 6.4 & 1.6 & $3.0210^{-12}$ \\
\hline HFO-1234yf & 114 & 0 & 4 & 7.0 & 0.3 & $3.9110^{-12}$ \\
\hline HFO-1225ye & 132 & 0 & 3 & 7.3 & 1.7 & $9.1210^{-13}$ \\
\hline
\end{tabular}


TABLE 2.3. Blowing agents for PU foams. Products with high ODP and suggested substitutes.

\begin{tabular}{|c|c|}
\hline $\begin{array}{l}\text { Substitute (and blends including that } \\
\text { substitute) }\end{array}$ & $\begin{array}{l}\text { Ozone-depleting Substance (ODS) Being } \\
\text { Replaced }\end{array}$ \\
\hline HCFC-123 & CFC-11 \\
\hline HFC-134a & CFC-11, HCFCs \\
\hline HFC-152a & CFC-11, HCFCs \\
\hline HFC-245fa & CFC-11, HCFCs \\
\hline HCFC-141b/HCFC-123 Blends & CFC-11 \\
\hline Formic Acid & CFC-11, HCFCs \\
\hline Saturated Light Hydrocarbons (C3-C6) & $\begin{array}{c}\text { CFC-11; HCFC-141b, HCFC-142b, HCFC-22 } \\
\text { (not listed as a substitute in spray foam } \\
\text { applications) }\end{array}$ \\
\hline Electroset Technology & $\begin{array}{c}\text { CFC-11; HCFC-22, HCFC-142b, and blends } \\
\text { thereof }\end{array}$ \\
\hline Carbon Dioxide & CFC-11, HCFCs \\
\hline Water & HCFCs \\
\hline Exxsol Blowing Agents & HCFCs \\
\hline Methyl Formate & CFC-11, HCFCs \\
\hline Ecomate & CFCs, HCFCs \\
\hline HFO-1234ze & CFCs, HCFCs \\
\hline HFC-365mfc & $\begin{array}{l}\text { HCFC-141b; HCFC-22, HFC-142b, and } \\
\text { blends thereof (not listed as a substitute } \\
\text { in spray foam applications) }\end{array}$ \\
\hline
\end{tabular}

\begin{tabular}{|c|c|}
\hline $\begin{array}{c}\text { Blends of HFC-365mfc and HFC-245fa, } \\
\text { containing at least } 5 \% \text { HFC- } 245 f a\end{array}$ & $\begin{array}{l}\text { HCFC-141b; HCFC-22, HFC-142b, and } \\
\text { blends thereof }\end{array}$ \\
\hline Formacel $^{\circledR} \mathrm{TI}$ & HCFC-22, HCFC-142b \\
\hline $\begin{array}{l}\text { Transcend }{ }^{\mathrm{TM}} \text { Technologies as an additive } \\
\text { to SNAP-approved blowing agents in } \\
\text { blends making up to } 5 \% \text { by weight of the } \\
\text { total foam formulation }\end{array}$ & CFCs, HCFCs \\
\hline Trans-1-chloro-3,3,3-trifluoroprop-1-ene & CFC-11, HCFC-141b \\
\hline Formacel ${ }^{\circledR}$ Z-6 & $\begin{array}{l}\text { HCFC-22, HCFC-142b, and blends thereof } \\
\text { (not listed as a substitute in spray foam } \\
\text { applications) }\end{array}$ \\
\hline
\end{tabular}


Recently, another non-flammable expansion agent $\mathrm{FEA}-1100^{57}$ has been proposed that has the added advantages of having low vapour thermal conductivity and low global warming potential. According to U.S. Environmental Protection Agency, Table $2.3^{58}$ shows blowing agents substitutes in rigid polyurethane: spray, commercial refrigeration, and Sandwich Panels. Substitutes are reviewed on the basis of ozone depletion potential, global warming potential, toxicity, flammability, and exposure potential. Lists of acceptable and unacceptable substitutes are updated several times each year, with the last update dating from August 2013.

\subsubsection{Cell structure of PU foams}

As it was previously discussed in the cellular materials section (Section 2.1), two types of cellular structures can be observed for cellular materials (and also for polyurethane materials) depending on the chemical composition of the polymer matrix and the foam evolution: closed or open cell. Usually both types of cellular structures coexist, and the nominal type of foam is the predominant one. The majority presence of one type or another of cellular structure highly determines the final foam properties. In the case of PU based materials, flexible polyurethane foams presents open cell structure, while rigid polyurethane foams present closed cell structure. As a result, flexible foams have better ability to absorb and damp sound, higher absorptive capacity for water and moisture and higher permeability to gas and vapour. Meanwhile, rigid foams present lower thermal conductivities and high mechanical properties $^{2}$.

\subsubsection{Foaming process}

Foaming process is a fundamental stage that must be analysed, as foams final properties are closely related with their cellular structure. For water blown rigid polyurethane foams, foaming process can be described in terms of the following five characteristics stages (Fig. 2.14), obtained from in situ analysis ${ }^{59}$ :

- Cream stage: In this point, when the $\mathrm{CO}_{2}$ generated as consequence of water and isocyanate reaction reaches the solubility limit, nucleation occurs: this is defined as the cream time. As the nucleation extends over a certain period of time, bubbles will not have all the same size, and a distribution of cell sizes will be produced $^{60}$. 
- Rise stage: Foaming starts when $\mathrm{CO}_{2}$ from liquid phase (zones with higher pressure) diffuses to previously created nuclei (zones with lower pressure). In this stage the foam is still liquid, and presents a metastable state that evolves dynamically due to several processes: macroscopic expansion, foam drainage (liquid flows through the interstitial volume between bubbles, i.e. from the cell walls to the struts), foam coarsening (due to gas exchange between bubbles) and coalescence of cells.

- Packing stage: generated $\mathrm{CO}_{2}$ rises the foam until a maximum height. The final bubble structure is formed. Urethane and urea formation continues, increasing the viscosity of the liquid phase until equilibrium with expansion forces is reached.

- Gelation stage: on this stage the foam reaches its final structure. Rigidity of the fluid is enough to consider bubbles as cells. Final size of the bubbles is reached, and no more drainage, coarsening, coalescence or expansion is produced. The cellular structure is stabilized.

- Solidification stage: this stage is reached when all the polymeric mass has gelled. Final structure is obtained. Crosslinking finishes and foam starts a curing period where cells become fully solidified.
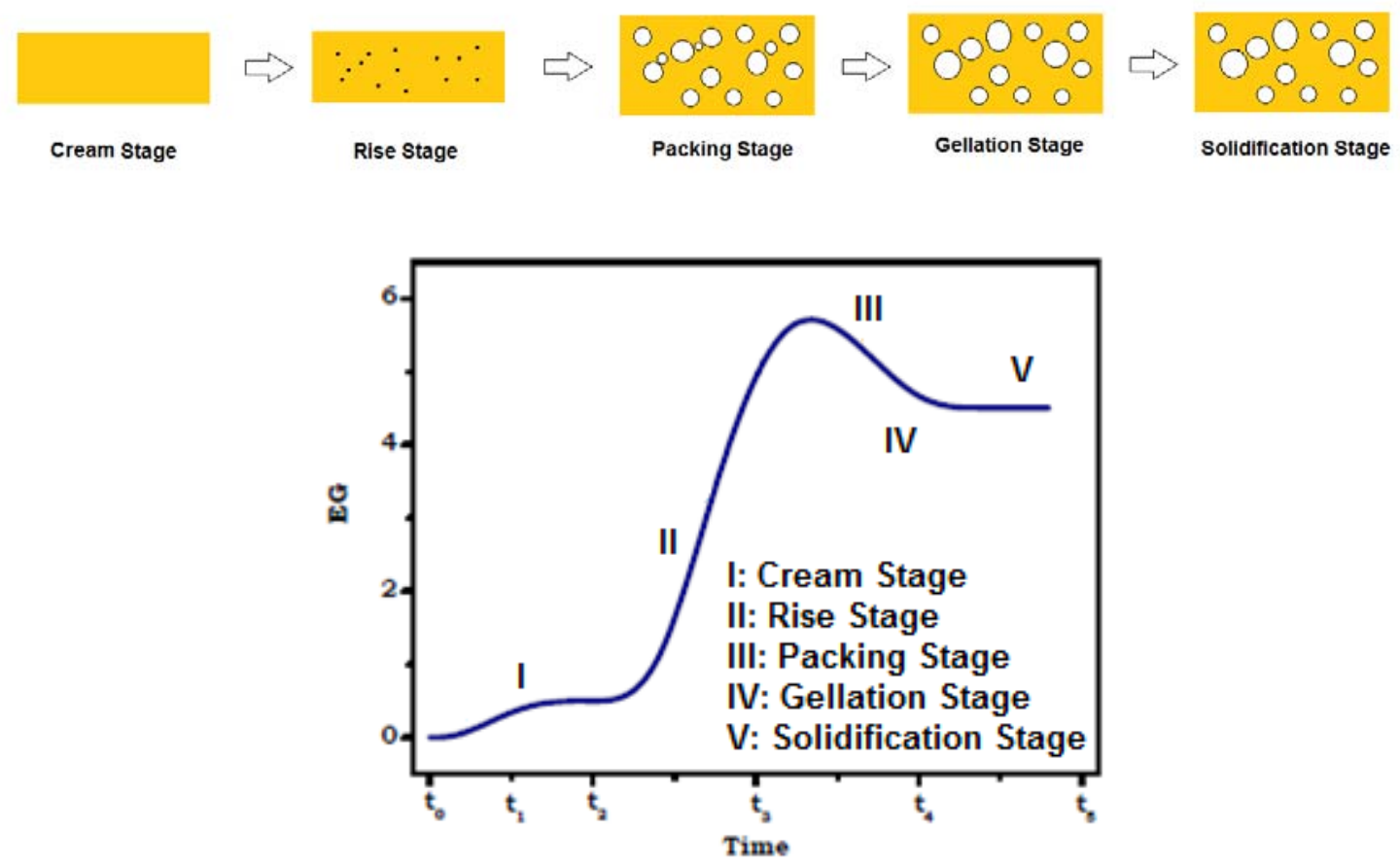

FIGURE 2.14: Visualization scheme of the different stages during foams expansion together with typical macroscopic expansion curve. 


\subsection{5.- Properties and applications}

Polyurethane foams have been employed in a wide range of applications since their invention. Nowadays these foams are a fundamental part of our lives, playing an important role in many industries as insulation, automotive, sports, naval, furniture and much more ${ }^{61}$. Wirpsza has situated polyurethane in the fifth position in the rank of production volume of plastics $^{62}$.

Rigid polyurethane foams present two main properties that determine their applications: on one hand their good mechanical properties, even for low densities; on the other hand their good insulating properties.

Due to their three dimensional cross linking that implies the presence of a threedimensional network ${ }^{63}$ with considerable mechanical properties, polyurethane rigid foams present a wide range of application in structural functions. This is also related with the high stiffness and strength to weight ratio, which allows reducing final weight without a great impact in the final mechanical properties. On this respect, the density of polyurethane rigid foams can be easily tuned, allowing to have a wider range of applications. Thereby, final density can be easily modified between 30 and $700 \mathrm{~kg} / \mathrm{m}^{331}$.

Of all insulating materials, such as powders, fibrous boards, multilayer systems, and vacuum panels, polymeric foams have the main advantages of being low-cost and, in general terms, easy to produce and maintain ${ }^{64}$. Because of these advantages, polymeric foams are the most widely used insulators in engineering applications. Concretely, polyurethane foams are the most popular foam insulators due to their low thermal conductivity, high strength-toweight ratio, good mechanical strength and low $\operatorname{cost}^{24,25,65,66}$.

As it has been mentioned, these properties determine significantly the final application of rigid polyurethane foams. For this reason, their applications are associated with their low thermal conductivity in construction, refrigeration appliances, automotive and technical insulation. Other applications are in sport and leisure sector, windows frames, core of sandwich panels and so on ${ }^{31}$ due to the excellent mechanical properties at low weights.

\subsection{Montmorillonites}

\subsubsection{Nanoparticles in polymer science}

The use of organic or inorganic fillers has become a standard in polymeric industry. Nowadays, polymer composites are manufactured commercially for a wide range of 
applications, such as sporting goods, aerospace components, construction, etc. But in the last 25 years there has been a great emphasis on the development of polymeric nanocomposites. In these materials at least one dimension of the filler is in the nanoscale range. In the early 1990s, Toyota Central Research Laboratories in Japan reported a work on a Nylon-6 nanocomposite $^{67}$, for which a very small amount of nano filler loading resulted in a pronounced improvement of thermal and mechanical properties. But the change in the final nanocomposite properties depends not only on the nature of the polymer and nanofiller, but also on their morphology and interfacial characteristics ${ }^{68}$.

Concretely the use of nanofillers (carbon nanotubes, carbon nanofibers, graphenes, nanosilicas, nanoclays, etc.) as aditive in foamed polymer systems is a hot topic involving significant research activity in the last few years ${ }^{29,69-71}$. The main objective of this research activity is to understand the physicochemical mechanisms associated with the polymernanofillers interaction, responsible of the cellular structures changes and the potentially better final properties. The addition of small amounts of well dispersed nanoadditives to traditional cellular polymers may result in synergistic effects. The polymeric matrix is reinforced with particles, and in addition the cellular structure might become strongly modified (reducing cell size, improving cell homogeneity, etc). This can imply an increase of several properties, such as the thermal insulation properties in rigid polyurethane foams infused with nanoclays studied by Modesti et al. ${ }^{41}$, or the emergence of new properties, like the change from insulator to semiconductor observed by Zheng el al. ${ }^{72}$ in PMMA infused with $1 \%$ expanded graphite, or the synergy in flame retardancy of polyurethane foams, investigated by Modesti et al. ${ }^{73}$, between phosphorus-based flame retardant and layered silicates, obtaining that clays act through physical effect constituting a barrier at the surface which is effective in preventing or slowing the diffusion of volatiles and oxygen, while phosphinate and phosphonium are more effective owing to their combined action in both condensed and gas phases. Furthermore, mechanical properties can be improved, as it was observed by Kojima et al. ${ }^{74}$ in Nylon6 by modified nanoclays addition, and by Zohu et al. ${ }^{75}$ in polyester-based polyurethanes films reinforced with nanosilica particles, obtaining an increase of some properties like hardness, abrasion resistance, and tensile properties at lower concentrations.

\subsubsection{Composition and structure of montmorillonites}

Generally, layered silicates employed in the nanocomposites synthesis are natural or synthetic minerals consisting of very thin layers that are usually bound together with counterions. Their basic building blocks are tetrahedral sheets in which silicon is surrounded by eight 
oxygen atoms. The basic 2:1 structure with silicon in the tetrahedral sheets and aluminum in the octahedrak sheet, without any substitution of atoms, is called pyrophyllite (Fig. 2.15). Since the layers do not expand in water, pyrophyllite has only an external surface area and essentially no internal one. If in the pyrophyllite structure the trivalent Al-cation in the octahedral layer is partially substituted by the divalent Mg-cation, the structure of monmorillonite is formed, which is the best-known member of a group of clay minerals, called smectites. In this case the overall negative charge is balanced by sodium and calcium ions, which exist hydrated in the interlayer ${ }^{76}$. This structure presents the particular feature that because the ions cannot fit in the tetrahedral layer, and these layers are held together by relative weak forces, water and other polar molecules can enter between the unit layers, causing the lattice expansion ${ }^{77}$. The general formula of montmorillonite is $M_{x}\left(A_{4-}\right.$ $\left.{ }_{x} \mathrm{Mg}_{\mathrm{x}}\right) \mathrm{Si}_{8} \mathrm{O}_{20}(\mathrm{OH})_{4}{ }^{78}$, where $M$ is a monovalent cation and $x$ is the degree of isomorphous substitution (between 0.5 and 1.3).

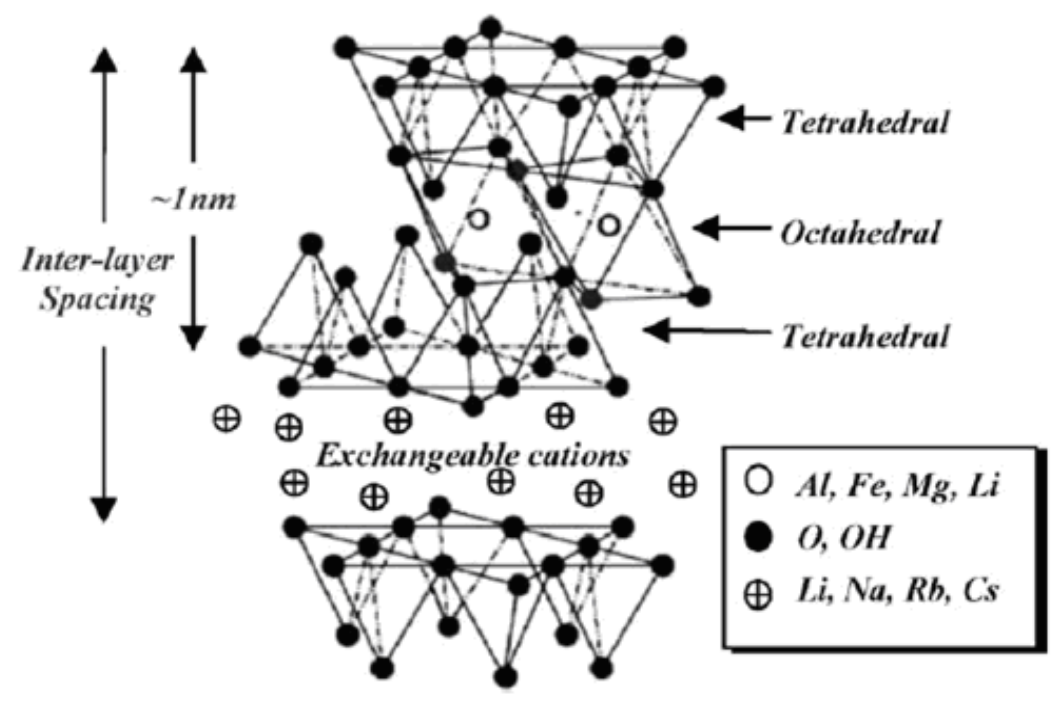

FIGURE 2.15. Structure of 2:1 phyllosilicates

Although basic structure of montmorillonites has been described, other levels of organization are present on these nanocomponents (Fig. 2.16). Besides the single layer structure, montmorillonites can be found forming particles and aggregates. Single layers are equivalent to a platelet varying from $10 \mathrm{~nm}$ to $1 \mu \mathrm{m}$ in size and a thickness of $1 \mathrm{~nm}$ (Fig. 2.16.a). These layers are flexible and deformable. Primary particles are composed from five to ten stacked layers, with an average thickness of $10 \mathrm{~nm}$ (Fig. 2.16.b). Different layers are joined by Van der Waals and electrostatic attraction forces between the cations and layers. The stacking of these particles is perpendicular to the $y$ direction. Finally, aggregates are the 
association of primary particles oriented in all directions, sizes between 0.1 to $10 \mu \mathrm{m}$ are typically found (Fig. 2.16.c).

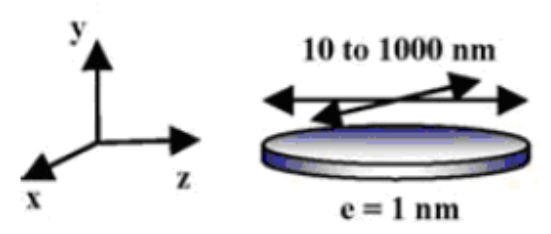

a.) Layer

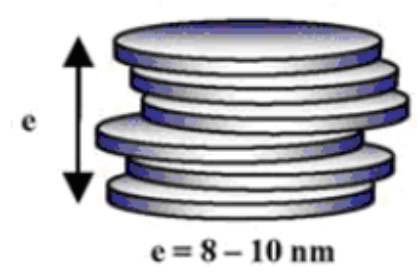

b.) Primary particle

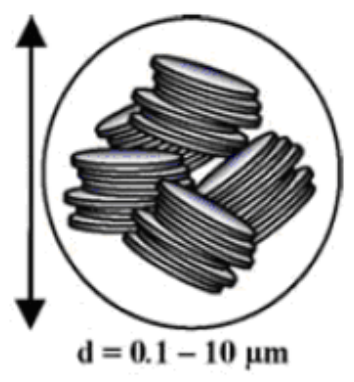

c.) Aggregate

FIGURE 2.16. Phyllosilicate multi-scale structure

Inter-layer spacing or d-spacing $\left(d_{001}\right)$, is the distance observed between two platelets of the primary particle. This value does not entirely depend on the layer crystal structure, but also on the type of the counter-cation and on the hydration state of the silicate. For instance, $\mathrm{d}_{001}=0.96 \mathrm{~nm}$ for anhydrous montmorillonite with sodium as counter ion, but $\mathrm{d}_{001}=1.2 \mathrm{~nm}$ in usual conditions. This increase is linked to the adsorption of one layer of water molecules between the clay platelets ${ }^{65}$.

The excess negative charge of layered silicates and their capability to exchange ions can be quantified by a specific property known as the cation-exchange capacity (CEC) expressed in miliequivalent/g ${ }^{79}$. This property is highly dependent on the nature of the isomorphous substitutions in the tetrahedral and octahedral layers and therefore on the nature of the soil where the clay was formed. This explains, for example, why montmorillonites from different origins show differences in CEC, ranging from approximately 0.9-1.2 miliequivalent/g ${ }^{77}$. The charge of the layer is not locally constant, as it varies from layer to layer, and must rather be considered as an average value over the whole crystal

Three different types of morphology in case of polymer-nanoclay composites are shown in Fig. 2.17. When polymer is unable to intercalate between the clay sheets, a phase separated microcomposites (Figure 2.17, a) is obtained. When there is partial intercalation of extended chain in between the sheets an intercalated nanocomposite (Figure 2.17, b) is obtained. Finally, when clay layers are completely dispersed in the polymer matrix an exfoliated nanocomposite is produced (Figure 2.17, c). The type of composite that is formed can be obtained by using X-ray diffraction as it shown in fig 2.17 . In the microcomposite it is possible to identify the signal of original clay in the XRD pattern, in the intercalated 
nanocomposite the signal is still present but at lower angles and with lower intensities. In the exfoliated nanocomposites the clay signal has disappeared.

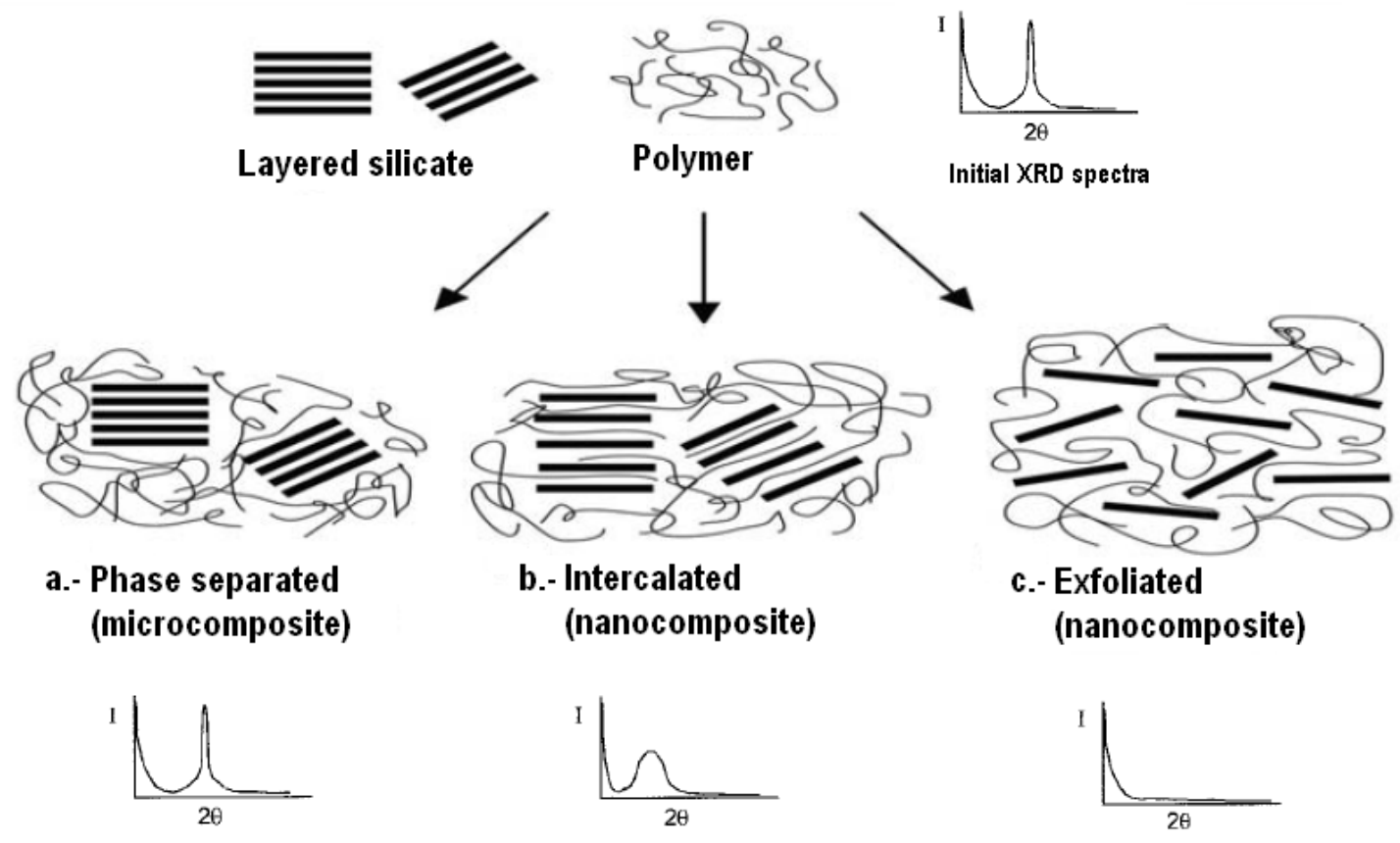

FIGURE 2.17.- Types of composites from polymer-clay interactions ${ }^{79}$ and schematic depicting the expected X-ray diffraction patterns for their structures, replotted from Vaia et al. ${ }^{80}$

\subsubsection{Functionalization}

Since pure montmorillonites are only miscible with hydrophilic polymers, a surface modification of them is required to obtain improved nanofillers, as a good polymermontmorillonite interaction (exfoliated structure) implies better properties transfer. Cation exchange is the most employed technique for this purpose, although techniques as the organosilane grafting ${ }^{81,82}$, the use of ionomers ${ }^{83}$ or block copolymers adsorption ${ }^{84}$ have been also employed.

In the cation exchange technique, the alkali counter-ions are exchanged with a cationic-organic surfactant (Fig. 2.18). Thereby, the inorganic, relatively small ions are exchanged, as they are not structural parts, by more voluminous organic cations, with two consequences: on one hand the surface energy of the silicate is lower, enabling polymer chains to move in between them and improving wetting with the polymer matrix ${ }^{85,86}$. Moreover, the long organic chains of such surfactants, with positively charged ends, are linked to the surface of the negatively charged silicate layers, resulting in an increase of the gallery height ${ }^{87}$ that makes easier for polymers to diffuse between the layer and even separate them ${ }^{86,88}$. On the 
other hand, surface properties of each single sheet are changed from being hydrophilic to hydrophobic ${ }^{89}$. The ionic substitution is performed into water because of the clay swelling, which facilitates the organic cations insertion between the platelets ${ }^{90}$. Various commercially available organo-modified montmorillonites, which mainly differ from the nature of their counter-cation, are produced with this technique (e.g., Cloisite 15A, 20A, 30B from Southern Clay Products).

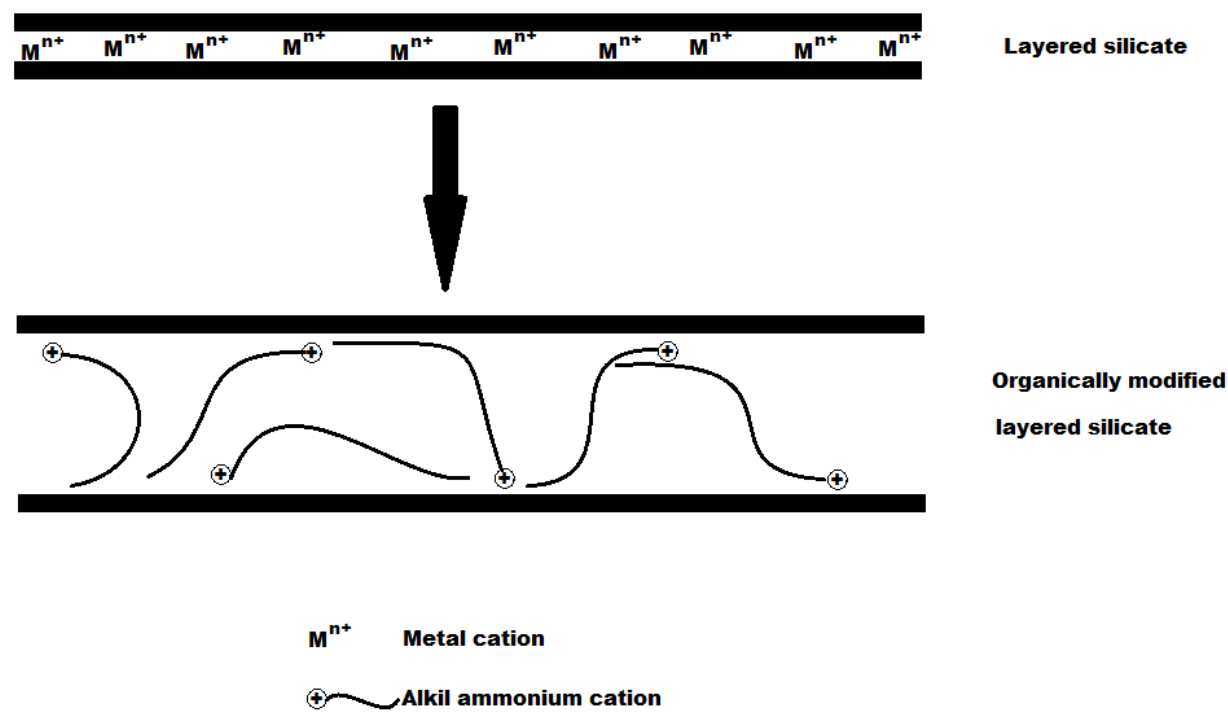

FIGURE 2.18.- Representation of a cation-exchange reaction between the layered silicate and an alkyl ammonium salt.

One of the most employed salt for the ionic substitution is Alkylammonium ions, although other "onium" salts can be used, such as sulfonium and phosphonium ${ }^{77,} 79$. Sometimes, the alkylammonium cations may even provide functional groups that can react with the polymer or initiate polymerization of monomers ${ }^{78}$. This fact makes possible the intercalation of polymer molecules, as the microchemical environment in the galleries is appropriate to $\mathrm{it}^{90}$. So, it is possible to conclude that the surface modification both increases the basal spacing of clays and serves as a compatibilizer between the hydrophilic clay and the hydrophobic polymer ${ }^{89}$.

Anyway, attempts to incorporate surface modified nano-particles into a matrix polymer using the ionic interaction with surfactant molecules gained only a moderate success. One point to keep in mind is the natural agglomeration tendency of the nanoparticles and how this led to thermodynamically unstable mixtures. For a better understand of these systems, 
three components have to be considered: the particle (surface), the interfacial component (surfactant) and the matrix polymer chains.
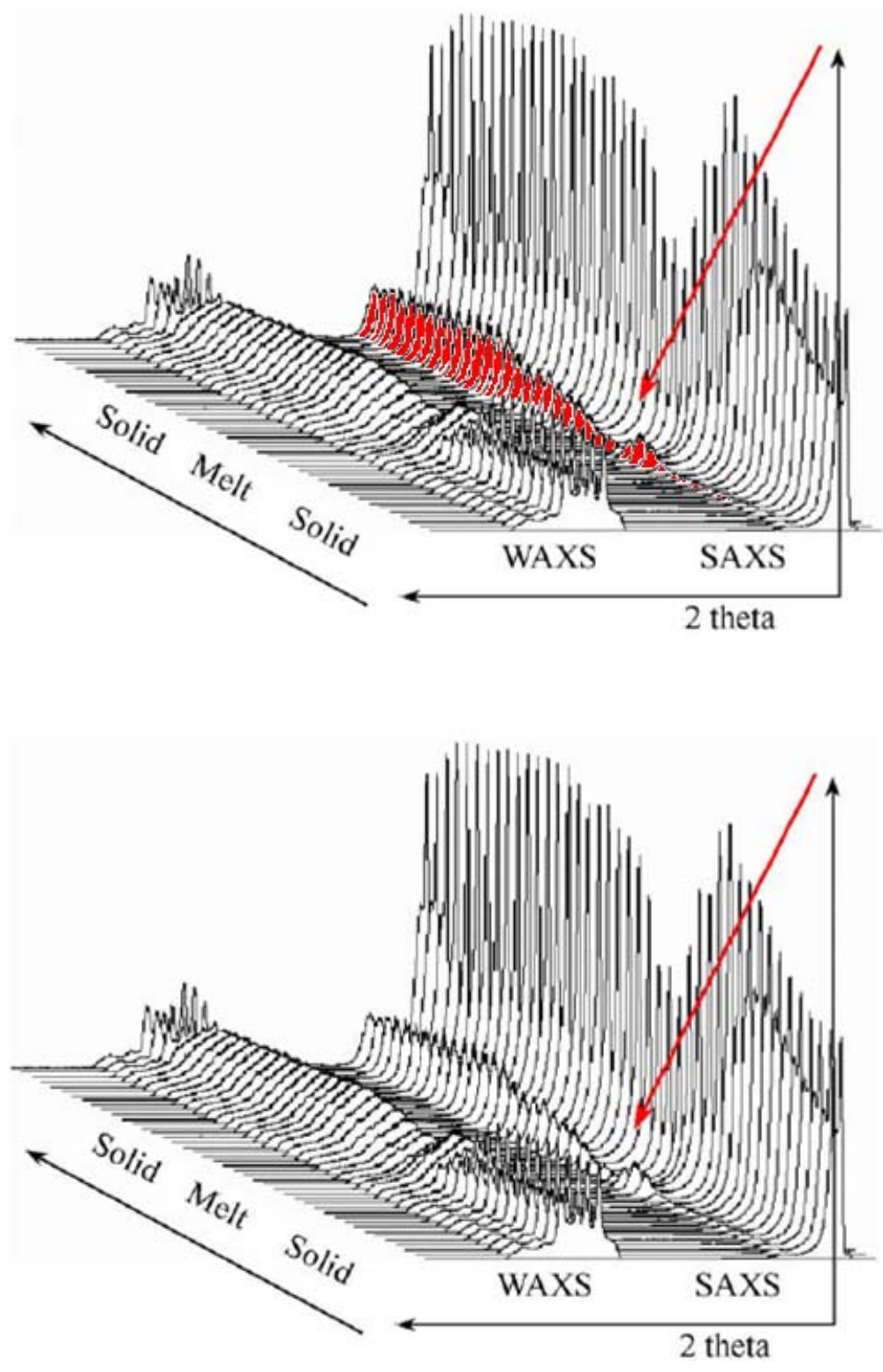

FIGURE 2.19.- In situ SAXS-WAXS experiment of the melting/crystallization of a iPP-clay nanocomposite material. The intrinsic homogeneous and exfoliated material (absence of any small angle reflection signal indicating a stacked layer packing of agglomerated clay sheets) changes almost immediately after melting of the iPP crystals into a heterogeneous system (appearance of the small angle signal). This small angle reflection is originated from a thermodynamic incompatibility of the surface modified sheets and the polymer matrix, causing a (partly) re-agglomeration of the clay sheet in the melt.

Theoretical studies ${ }^{91}$ have shown that the interaction enthalpy between the surfactant molecules and the polymer chains may be the key for a thermodyamically stable, homogenous 
incorporation of nano-particles into a polymer matrix. This is because the entropy loss of the gap between single particles as a consequence of the penetrating polymer chains will be approximately compensated by the entropy gain of the surfactant molecules in interaction with polymer chains.

A lattice-based mean field theory has been developed by Vaia ${ }^{91}$ to understand the impact of the different interaction enthalpies onto the possibility of dispersion of particles in a polymer matrix. Here three different interactions must be taken into account: polymersurfactant, surfactant-surface and polymer-surface interactions. Calculations of this theory has shown that even when the surfactant chains are miscible with the matrix polymer, a complete layer separation depends on the establishment of very favorable polymer-surface interactions to get over the polymer confinement. When this is not possible, a good dispersion of the particles may be reached by the help of strong shear forces during the preparation and the processing of the nanocomposite materials, but the system nevertheless will be thermodynamically unstable. This can be observed in the case of iPP or LLDPE nanocomposite materials which were prepared by melt mixing of the polymers with surface modified natural clay (ion-exchanged with dimethydioctadecylammoinum ions) using high shear forces. If such a mixture is heated (e.g. during processing) to temperatures above the melting temperature, immediately a (partial) re-agglomeration of the particles takes place (see fig. 2.19). A different possibility of creating a homogeneous dispersion of surface modified nano-particles within a polymer matrix material is the decrease of the strength of the interactions surfactant-surface and surfactant-polymer, which results in an increase of the interaction strength polymersurface, e.g. by the use of fluorinated surfactants.

\subsection{Foamed polyurethane nanocomposite filled with nanoclays: State of the Art}

Different aspects involved both in the production and characterization of foamed rigid polyurethane nanocomposites can be found in a review of the most recent literature focused on these materials. Between all, special attention has been given to the next items: blowing agents and density, dispersion technique used to produce the nanocomposite, nanoclays concentration, cellular structure, thermal conductivity and mechanical properties.

\subsubsection{Density and Foaming Agents}

Most of the publications made in this field are focused in low density foams, with values between 30 and $110 \mathrm{~kg} / \mathrm{m}^{3}$. Depending on the requirements of the final foam higher or lower densities have been produced. 
Figure 2.20 shows the different densities observed over a variety of studies (a total number of 15 publications were found) focused on rigid polyurethane foams infused with nanoclays. It can be observed that the vast majority of the articles are oriented to densities between 25 and $75 \mathrm{~kg} / \mathrm{m}^{3}$. Anyway, it is important to mention that density was not measured in some of the articles studied ${ }^{17,45}$, something that cannot be understood taking into account the fundamental role that the density plays in the foams properties ${ }^{1}$. In most of the analysed papers the change in density due to the clays addition was small, not higher than $5 \mathrm{~kg} / \mathrm{m}^{3}$.

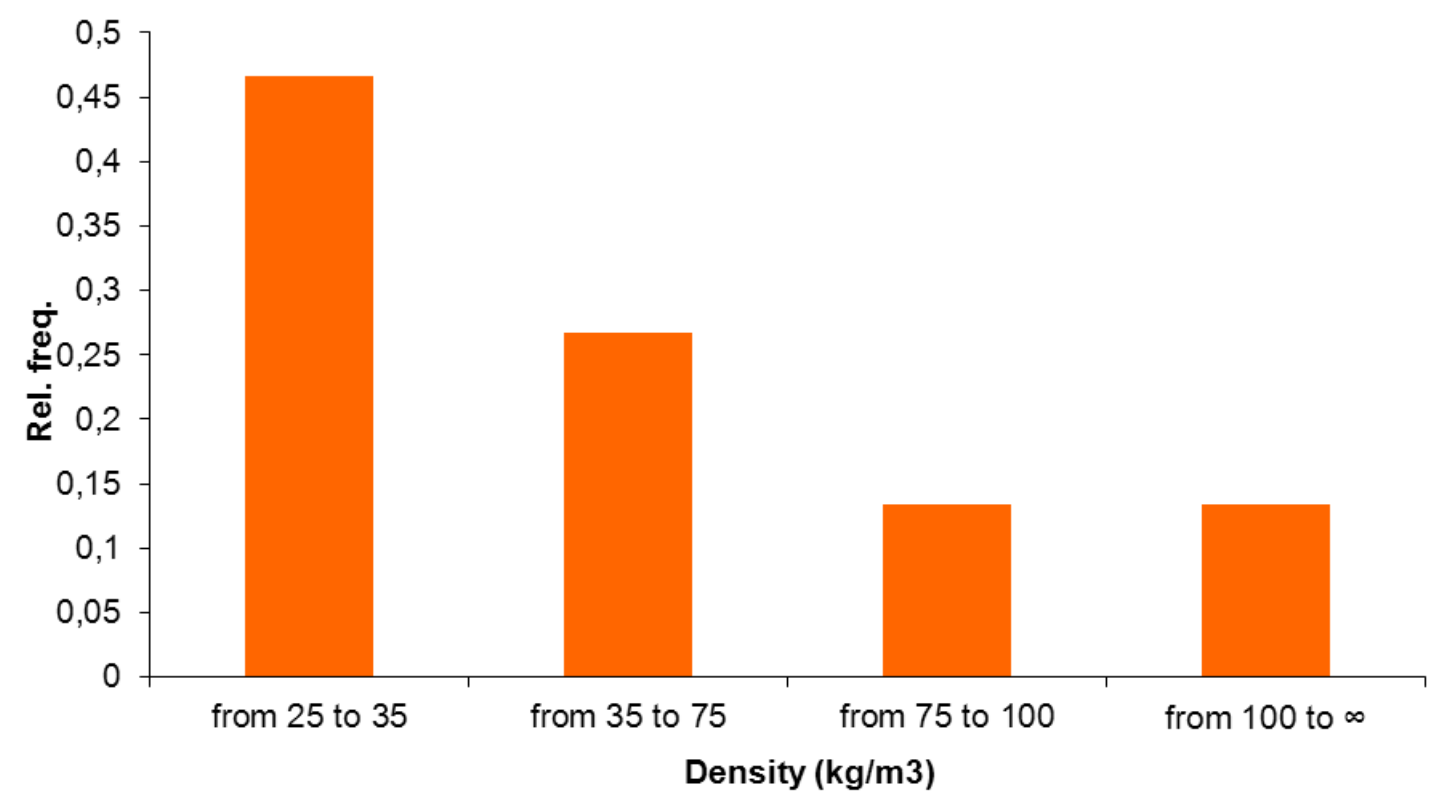

FIGURE 2.20.- Relative frequency of pappers published in different densities ranges

But in some cases, nanoparticles can produce a considerable change in final foam density, as in the study performed by Bahrambeygi et al. ${ }^{92}$ where densities changed from 45 $\mathrm{kg} / \mathrm{m}^{3}$ for the pure material to more than $90 \mathrm{~kg} / \mathrm{m}^{3}$ for $1.5 \%$ of nanoclays. In addition, in the study of Piszczyk et al. ${ }^{93}$, density varies from around $20 \mathrm{~kg} / \mathrm{m}^{3}$ for pure material to around 40 $\mathrm{kg} / \mathrm{m}^{3}$ for materials infused with bentonite. Although nanoclays are usually dehydrated in a vacuum oven for several hours prior to their incorporation and dispersion in polyurethane components, this do not always guarantee the complete absence of water in the nanoclays that could act as chemical blowing agent. In this respect, the results obtained by Xu et al. ${ }^{94}$ confirm this, as foamed rigid polyurethane containing nanoclays were produced without any blowing agent, only with the inclusion of nanoclays. In this study, organoclays were dehydrated in an oven at $70^{\circ} \mathrm{C}$ overnight before use. The observed behavior was due to the presence of water on nanoclays: although the desorbed water molecules that absorb the cations between interlayers of clay evaporate in the temperature range of $50-170^{\circ} \mathrm{C}$, the 
dehydroxylation of bound water molecules from the crystal lattice of pristine clay occurs in the temperature range of $450-900{ }^{\circ} C^{95,96}$. Then, the temperatures reached during overnight dehydration are not enough to completely eliminate nanoclays water, and this could react with isocyanate acting as a blowing agent.

Possible explanations of these density increase found in the papers by Bahrambeygi and Piszczyk, and compatible with the previous one, and can be based first in that the density of the nanofillers (e.g. Cloisite $30 \mathrm{~B}-1.98 \mathrm{~g} / \mathrm{cm} 3$ ) is usually higher than that of the polymeric matrix (typically $1.2 \mathrm{~g} / \mathrm{cm}^{3}$ for polyurethane). Secondly, the viscosity of the polyol mixture containing nanofillers is higher than the viscosity of the mixture of the unmodified polyol. The increase in viscosity of the polyol mixture could hinder the foaming process which results in higher density foams ${ }^{97}$.

The blowing agents employed in the production of low density polyurethane foams is a non-trivial subject, as the thermal conductivity of this material presents a high dependence with the thermal conductivity of the gas present inside its cells (see section 2.1.4). For this reason, diffusivity of the foaming agent out of the foam is a fundamental key; if the gas diffuses outside the foam the thermal insulation ability of the material will be deteriorated. On this respect, the most used foaming gas has been trichlorofluoromethane (CFC), due to due to its lowest diffusion coefficient and low thermal conductivity, but nowadays is banned (as it was previously mentioned on section 2.2.2) by environmental reasons. Moreover, alternative gases such as HCFC-141b are also supposed to be banned after the year 2030 for the same reasons as $\mathrm{CFC}^{98}$. Another foaming agent like water is environmentally friendly, but presents the disadvantage that, although thermal conductivity of resulting $\mathrm{CO}_{2}$ is low (lower than that of air), its diffusivity across the cell walls is really high and is quickly substituted by air ${ }^{99}$.

Anyway, the foaming agent employed in the vast majority of the publications is water. In articles in which foams with densities lower than $50 \mathrm{~kg} / \mathrm{m}^{3}$ are produced, both chemical (water) and physical foaming agents are simultaneously employed, as the only addition of water implies a high viscosity system and a large amount of heat (exotherm reaction) while preparing the foam, which may lead to risk of fire and scorch the foam. Sometimes, the system cost is high due to the increase in the use of excess of isocyanate ${ }^{43}$. Some of the additional physical blowing agents employed are HCFC $141 b^{44}$, cyclopentane ${ }^{39,45,46}$, isopentane ${ }^{39,46}, \mathrm{n}$ pentane $^{94,100,} 101$ and blends of 1,1,1,3,3- pentafluorobutane and 1,1,1,2,3,3,3heptafluoropropane $e^{17,74,102}$. 


\subsubsection{Dispersion Techniques used to produce the polyurethane nanocomposite} foams

Nanoclays drying is a common procedure in practically all papers where this additive is employed. For this subject it is usually employed a vacuum oven at $60-70$ 으, or a conventional oven at $100-110 \circ \mathrm{C}$. Drying time varies between 4-6 hours and overnight, but as it was previously mentioned, evaporating of water molecules (from the crystal lattice of pristine clay) occurs in the temperature range of $450-900 \circ C$, therefore not all moisture will be removed from the nanoparticles by the typical drying processes used ${ }^{96,97}$.

After drying, the first problem that emerges in the inclusion of nanoparticles in a polyurethane matrix is how to disperse them and how to exfoliate them in an optimal way. This is a crucial step in order to obtain a new material with improved properties, as much of the benefits of nanoclays incorporation depend on achieving of a good dispersion and exfoliation. As it had been previously commented, nanoclays functionalization can improve dramatically the nanoclays-polymer interaction, and moreover nanoclays exfoliation. What is more, the use of a good dispersion technique can also affect not only this fact, but also the improvement of the nanoparticles-polymer surface contact by an increase in the dispersion.

As rigid polyurethane foams reactives are liquid, the inclusion of nanoparticles implies their dispersion in a liquid media. Although alternative dispersion and exfoliation techniques as microwaves processing ${ }^{103}$ have been investigated showing promising results (see below), mainly two different techniques have been employed for this objective: shear mixing and ultrasonication.

Shear mixing can be carried out at low (less than $1000 \mathrm{rpm}^{103}$ ) or high speed (more than $1000 \mathrm{rpm}^{104,105}$ ), although in the vast majority of the studied papers mixing speed is not mentioned, and in the best of the cases adjectives as "vigorous" 80 is provided. This dispersion is inherently unstable and precipitation of clay occurs after 1 day or more ${ }^{105}$. In the majority of the papers including this technique mixing time oscillates between some minutes ${ }^{46,104,106,107}$ and several hours ${ }^{47,108,109}$.

Ultra-sonication consists in applying ultrasound energy to agitate particles in a solution for various purposes. In the laboratory, it is usually achieved using an ultrasonic bath or an ultrasonic probe/ horn, also known as an ultrasonicator. This is the most frequently used method for nanoparticles dispersion in liquids. This technique is based in the attenuated waves induced in the molecules of the medium in which ultrasonication are propagated. The 
production of these shock waves promotes the "peeling off" of individual nanoparticles located at the outer part of the nanoparticle bundles, or agglomerates, and thus results in the separation of individualized nanoparticles from the bundles. As drawback, high temperatures are produced during ultra-sonication, which can produce a degradation of the polyol or isocyanate. For this reason a raw polyol is required, because commercial formulations include additives like surfactants and catalyst that can be easily degraded.

An alternative dispersion technique was also found; the use of microwaves ${ }^{103}$. Lorenzetti et al. employed a microwave treatment with a microwave oven (700W power, 2.45 $\mathrm{GHz}$ ), on polyol and isocyanate, for 2 minutes. In particular, microwave processing was applied through $15 \mathrm{~s}$ step, followed by intermediate cooling at 50 o $\mathrm{C}$ using a water, ice and acetone bath, because, on the contrary, a quick temperature increase was observed (without

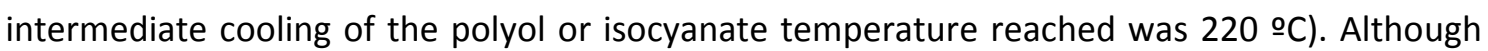
good results of exfoliation were obtained in comparison with sonication technique, maybe the parameters employed in both techniques were not the optimum to ensure an equal comparison, at least for ultrasonication. Possibly shorter times of ultrasonication could have produce similar effects, and one of the advantages of the new dispersion technique to ultrasonication could have been omitted. Finally, another dispersion technique could been suitable to be compared, providing a wider spectrum of dispersion power.

Comparing traditional techniques of high shear mixing and ultra-sonication, Rhoney et al. ${ }^{105}$ studied nanocomposites produced using two different types of organically modified montmorillonite clays and a sample of fine particles of silicon nitride as a reference material. Rheological techniques, wide angle X-ray scattering measurements and dynamic mechanical analysis were employed to perform this study. As conclusion, the dispersion with shear mixers was inherently unstable and precipitation of clay took place over a period of 1 day or more; on the other hand the sonicated samples produced dispersions that were stable for weeks or more. The sonication process appears not only able to achieve a better but also a more stable dispersion. Surprisingly, there were no marked differences in the $T g^{\prime}$ 's of the polyurethanes with the dispersion method, and both methods of dispersion were able to provide a reinforcing effect, albeit a slight one, on the final foams.

\subsubsection{Nanoclays concentration}

One of the theoretical advantages of employing nanoclays is the reduction of the amount of material added to produce similar, or even better, results than when using classical, 
micrometric size particles. The percentage by weight (mass fraction) of the nanoparticulates introduced can remain very low (of the order of $0.5 \%$ to $5 \%$ ) due to the low filler percolation threshold, especially for the most commonly used non-spherical, high aspect ratio fillers (e.g. nanometer-thin platelets, such as clays, or nanometer-diameter cylinders, such as carbon nanotubes). Table 2.4 compare different fillers comontly employed in a review by Ma et al. ${ }^{110}$ :

TABLE 2.4. Dimension and corresponding number of particles in composites for different fillers at equal volume concentration

\begin{tabular}{|c|c|c|c|c|}
\hline \multirow[b]{2}{*}{ Filler } & \multicolumn{4}{|l|}{ Description } \\
\hline & $\begin{array}{l}\text { Average dimension } \\
\text { of filler }\end{array}$ & $\begin{array}{l}\text { Density } \\
\left(\mathrm{g} / \mathrm{cm}^{3}\right)\end{array}$ & $N^{a}$ & $s^{b}$ \\
\hline $\begin{array}{l}\mathrm{Al}_{2} \mathrm{O}_{3} \\
\text { particle }\end{array}$ & $100 \mu \mathrm{m}$ in diameter $(d)$ & 4.0 & 1.9 & $S=\pi d^{2}$ \\
\hline $\begin{array}{l}\text { Carbon } \\
\text { fiber }\end{array}$ & $\begin{array}{l}5 \mu \mathrm{m} \text { in diameter } \\
(d) \times 200 \mu \mathrm{m} \text { in length }(l)\end{array}$ & 2.25 & 255 & $\begin{array}{l}S=\pi d l+ \\
\pi d^{2} / 2\end{array}$ \\
\hline GNP & $\begin{array}{l}45 \mu \mathrm{m} \text { in length (square, } \\
l .7 .5 \mathrm{~nm} \text { in thickness }(t)\end{array}$ & 2.2 & $6.58 \times 10^{4}$ & $\begin{array}{l}S=4 t^{2}+ \\
2 l t\end{array}$ \\
\hline CNT & $\begin{array}{l}12 \mathrm{~nm} \text { in diameter } \\
(d) \times 20 \mu \mathrm{m} \text { in length }(l)\end{array}$ & 1.8 & $4.42 \times 10^{8}$ & $\begin{array}{l}S=\pi d l+ \\
\pi d^{2} / 2\end{array}$ \\
\hline
\end{tabular}

${ }^{\text {a }} \mathrm{N}$ : number of particles in $1.0 \mathrm{~mm}^{3}$ with 0.1 vol.\% filler content.

b $S$ : surface area of individual particles.

Data on $\mathrm{Al}_{2} \mathrm{O}_{3}$ particles, carbon fibers, graphite nanoplatelets (GNPs) and CNTs are given, they correspond to the number of particles in an uniform filler volume fraction of $0.1 \%$ in a composite of $1.0 \mathrm{~mm}^{3}$ cube. Because there are large differences in dimension and geometry of these four different reinforcements, the number of fillers contained for a given filler volume fraction is also very different, as it can be seen in Table 2.4 and Fig. 2.21 (the three dimensional representation of these fillers in a polymeric matrix). However, when GNPs and CNTs are filled into the same volume of matrix, it is hard to disperse individual particles uniformly. Considering the particle agglomeration due to the electrostatic interaction and Van der Waals forces, the real distribution of nano-scale fillers should be more complicated than the schematics shown here.

A

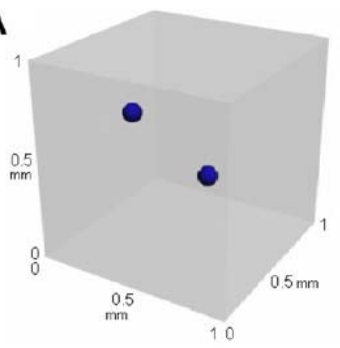

B

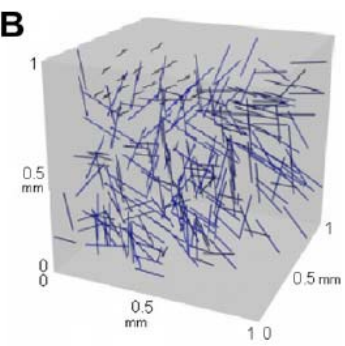

C

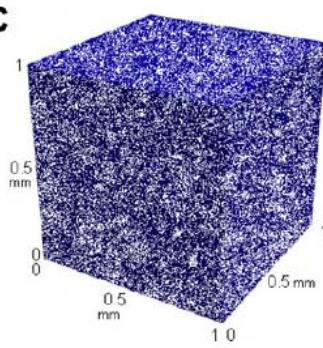

D

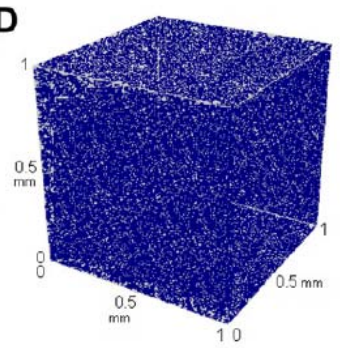

FIGURE 2.21.- Distribution of micro- and nano-scale fillers at the same 0.1 vol\% in a reference volume of $1 \mathrm{~mm} 3\left(\mathrm{~A}: \mathrm{Al}_{2} \mathrm{O}_{3}\right.$ particles, $\mathrm{B}$ : carbon fibers, $\left.\mathrm{C}: \mathrm{GNP}, \mathrm{D}: \mathrm{CNT}\right)$ 
For polyurethane-nanoclays composites, the relative frequencies of different concentrations of nanoclays observed in scientific literature are present in Fig. 2.22. The study has been performed over 26 publications. As it is shown, practically all studies are referred to concentrations lower or equal to $5 \%$. And there are two sub-categories: from 0 to $1 \%$, and between 1 and 5\%, with a higher amount of publications in the second one.

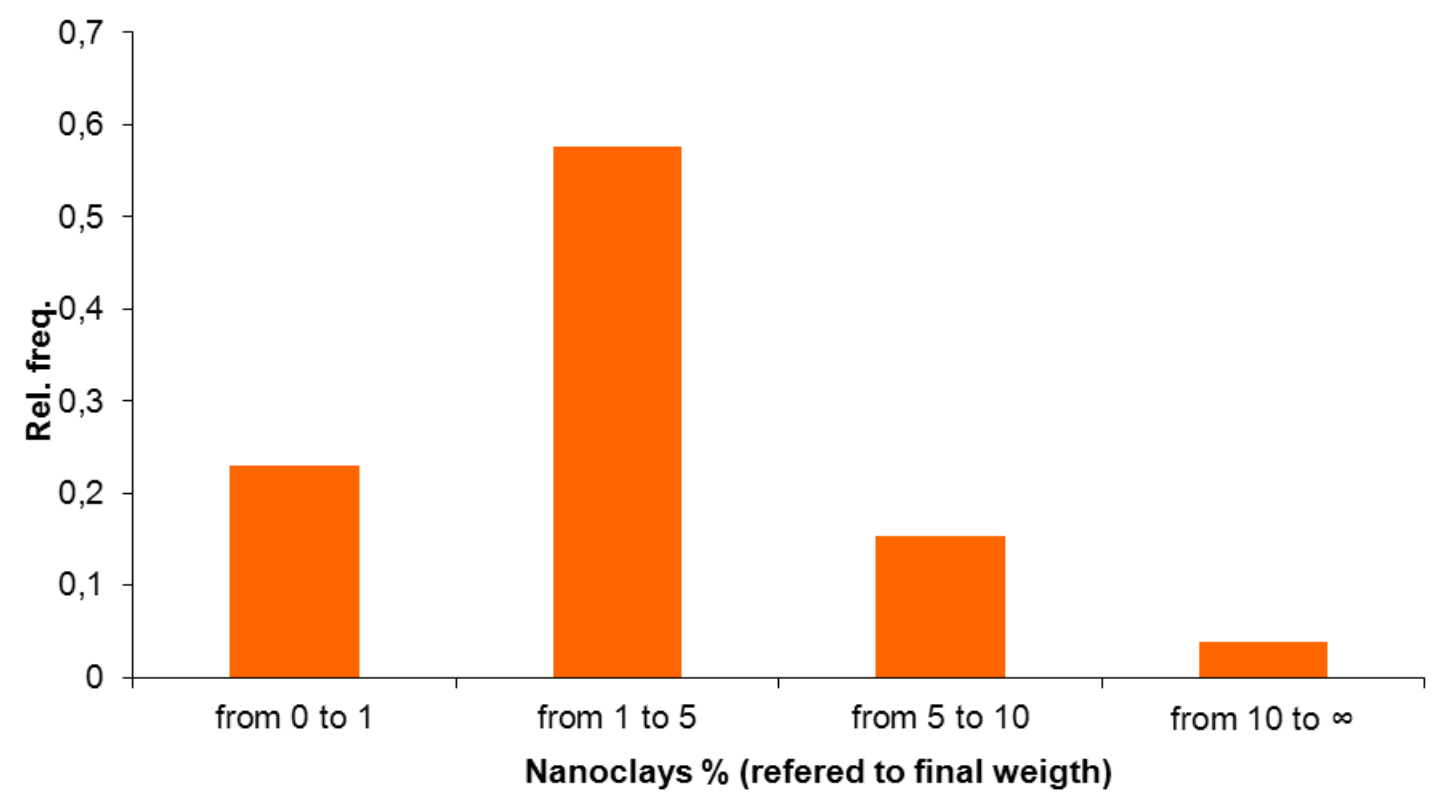

FIGURE 2.22.- Relative frequency of publications as a function of the weigth concentration of nanoclays

\subsubsection{Cellular Structure and Thermal Conductivity}

The thermal conductivity of foams present a clear dependence with the foam cell $\operatorname{size}^{74,111}$, so that a reduction of the cell size produces a reduction of the thermal conductivity. As nanoclays can reduce the cell size of the foams due to a possible nucleating effect, a thermal conductivity reduction can also be produced. Not many publications have been focused on this subject; the most relevant are described on the following paragraphs.

Modesti, Lorenzetti and Besco studied the thermal behaviour with the presence of nanoparticles ${ }^{41}$, observing the effect of different nanofillers (titanium dioxide, silica nanopowder and three types of montmorillonites: pure, modified with enzyl-dimethylhydrogenated-tallow ammonium-salt and modified with alkyl-imidazolium salt) on the thermal insulating properties of polyurethane nanocomposites foams. Two types of polyols were employed: polyether polyol and polyether-polyester polyol, and fillers were first dispersed in polyol component by using sonication. Blowing agent employed was 1,1,1,3,3- 
pentafluorobutane (365 mfc, Solvay) and water. A good degree of dispersion was achieved, and in general the thermal conductivity of foams was slightly reduced. On the other hand, the fillers could have brought in some cases an increase of the open cell content making the diffusion rate of the blowing agents faster, which might result in worse thermal insulating properties over time. Between the different types of nanoclays employed, best results were obtained for benzyl-dimethyl-hydrogenated-tallow ammonium-salt modified montmorillonite, observing a cell size and thermal conductivity reduction. Also, although a good degree of dispersion was claimed, the XRD results for some polyether and polyether-polyester based foams showed that a good exfoliation of nanoclays was not always achieved. Better exfoliation results were obtained for both polyether and polyether-polyester with organomodified montmorillonites, with a higher separation between platelets for polyether-polyester polyol. Anyway, this study showed that chemical nature and viscosity of polyol plays an important role as some clear positive effects on thermal conductivity can be obtained only for polyetherpolyester based foams; also it was observed that nanoparticles aspect ratio is not as important as the nanoparticles functionalization. Due to the high number of formulation/nanoparticles studied (see Fig. 2.23), the nanoclays effect on the final properties was not deeply studied. Maybe, a more detailed characterization of the open cell content and the cellular structure had cleared some of the experimental results obtained.

\begin{tabular}{|c|c|c|c|c|c|c|}
\hline \multirow[b]{2}{*}{ Formulation $(\mathrm{g})$} & \multicolumn{6}{|c|}{ Sample } \\
\hline & $\mathrm{XE}$ & XED43B & XELVF & XEIM-MMT & $\mathrm{XESiO}_{2}$ & $\mathrm{XETiO}_{2}$ \\
\hline Isoexter 4530 & 40 & 40 & 40 & 40 & 40 & 40 \\
\hline Isoexter 4537 & 40 & 40 & 40 & 40 & 40 & 40 \\
\hline Voranol RN 490 & 20 & 20 & 20 & 20 & 20 & 20 \\
\hline DMCHA & 1 & 1 & 1 & 1 & 1 & 1 \\
\hline PMDETA & 0.8 & 0.8 & 0.8 & 0.8 & 0.8 & 0.8 \\
\hline В 8471 & 2.5 & 2.5 & 2.5 & 2.5 & 2.5 & 2.5 \\
\hline $\mathrm{HFC} 365 \mathrm{mfc}$ & 24.8 & 24.8 & 24.8 & 24.8 & 24.8 & 24.8 \\
\hline $\mathrm{H}_{2} \mathrm{O}$ & 1.5 & 1.5 & 1.5 & 1.5 & 1.5 & 1.5 \\
\hline Voranate M 600 & 160 & 160 & 160 & 160 & 160 & 160 \\
\hline Dellite 43 B & - & 5 & - & - & - & - \\
\hline Dellite LVF & - & - & 5 & - & - & - \\
\hline IM-MMT & - & - & - & 5 & - & - \\
\hline $\mathrm{SiO}_{2}$ & - & - & - & - & 5 & - \\
\hline $\mathrm{TiO}_{2}$ & - & - & - & - & - & 5 \\
\hline Density $\left(\mathrm{kg} / \mathrm{m}^{3}\right)$ & 36.6 & 34.1 & 33.1 & 37.1 & 33.5 & 38.1 \\
\hline
\end{tabular}

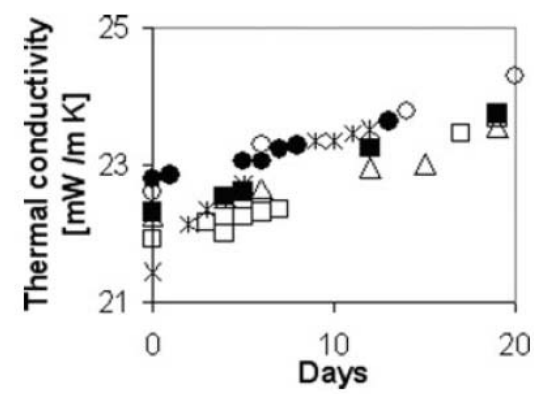

FIG. 2. Thermal conductivity of unfilled and filled polyether-polyester based foams $\left(\bullet\right.$. Sample XE; $\mathbf{\square}$, sample XE $\mathrm{SiO}_{2}: \triangle$, sample XE IMMMT; $\square$, sample XE D43B; O, sample XE LVF; *, sample XE $\mathrm{TiO}_{2}$ ).

\begin{tabular}{|c|c|c|c|c|c|c|}
\hline \multirow[b]{2}{*}{ Formulation $(\mathrm{g})$} & \multicolumn{6}{|c|}{ Sample } \\
\hline & $\mathrm{E}$ & ED43B & ELVF & EIM-MMT & $\mathrm{ESiO}_{2}$ & $\mathrm{ETiO}_{2}$ \\
\hline Voranol RN 490 & 100 & 100 & 100 & 100 & 100 & 100 \\
\hline DMCHA & 1.6 & 1.6 & 2.0 & 1.6 & 2.0 & 2.0 \\
\hline PMDETA & 0.6 & 0.6 & 0.6 & 0.6 & 0.8 & 0.8 \\
\hline B 8471 & 2.5 & 2.5 & 2.5 & 2.5 & 2.5 & 2.5 \\
\hline HFC $365 \mathrm{mfc}$ & 26.9 & 26.9 & 26.9 & 26.9 & 26.9 & 26.9 \\
\hline $\mathrm{H}_{2} \mathrm{O}$ & 1.5 & 1.5 & 1.5 & 1.5 & 1.5 & 1.5 \\
\hline Voranate M 600 & 173.5 & 173.5 & 173.5 & 173.5 & 173.5 & 173.5 \\
\hline Dellite 43 B & - & 5 & - & - & - & - \\
\hline Dellite LVF & - & - & 5 & - & - & - \\
\hline IM-MMT & - & - & - & 5 & - & - \\
\hline $\mathrm{SiO}_{2}$ & & - & - & - & 5 & - \\
\hline $\mathrm{TiO}_{2}$ & & & & & & 5 \\
\hline Density $\left[\mathrm{kg} / \mathrm{m}^{3}\right]$ & 32.2 & 34.7 & 32.7 & 36.6 & 32.0 & 34.1 \\
\hline
\end{tabular}

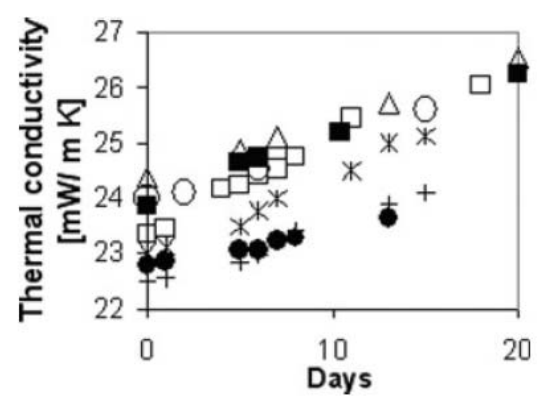

FIG. 1. Thermal conductivity of unfilled and filled polyether-based foams (+, sample E; $\square$, sample E D43B; $\triangle$, sample E IM-MMT; sample $\mathrm{E} \mathrm{SiO}_{2}, \mathrm{O}$, sample E LVF; $\bullet$, Sample XE; *, sample E $\mathrm{TiO}_{2}$ ).

FIGURE 2.23.- List of samples and thermal conductivity measurements results. 
Harikrishnan et al. ${ }^{47}$ performed other study of the nanoclays effect on thermal properties of rigid polyurethane foams. In that publication, rigid and flexible foams infused with nanoclays were studied with the main goal of observing the effect of nanoclays over the open cell content. Blowing agents employed were HCFC $141 \mathrm{~b}$ and water. It was found that clays act as efficient cell openers in both rigid and flexible foams as a larger fraction of open cells was obtained with increasing clays concentration. Modified clays were found to be more efficient cell openers than the unmodified clay. Thermal conductivity of the rigid foams was not significantly affected by clay addition. Although modified clays produced higher cell size reduction (Fig. 2.24.a) which could produce a reduction of the thermal conductivity ${ }^{90,99}$, they also produced higher open cell content (Fig. 2.24.b), and finally best thermal properties where produced for unmodified nanoclays (Fig. 2.24.c), with around 7\% reduction with respect to pure material. Again, the variety of samples studied prevented a more detailed characterization, and different questions about the thermal conductivity variation by the nanoclays addition were not solved.

\begin{tabular}{lc} 
Table 9. Cell Window Area of Foam Samples \\
\hline foam type & cell window area $\left(\mathrm{mm}^{2}\right)$ \\
\hline conventional (flexible) & $0.0152 \pm 0.0052$ \\
2 pphp CNa (flexible) & $0.0173 \pm 0.0053$ \\
1 pphp C15A (flexible) & $0.0095 \pm 0.0015$ \\
1 pphp C25A (flexible) & $0.0187 \pm 0.0041$ \\
0.5 pphp C93A (flexible) & $0.0114 \pm 0.0022$ \\
Conventional (rigid) & $0.0448 \pm 0.0073$ \\
2 pphp CNa (rigid) & $0.0421 \pm 0.0082$ \\
5 pphp CNa (rigid) & $0.0462 \pm 0.0004$ \\
8 pphp CNa (rigid) & $0.0426 \pm 0.0009$ \\
2 pphp C25A (rigid) & $0.0411 \pm 0.0014$ \\
5 pphp C25A (rigid) & $0.0214 \pm 0.0008$ \\
8 pphp C25A (rigid) & $0.0253 \pm 0.0002$ \\
2 pphp C20A (rigid) & $0.0162 \pm 0.0003$ \\
5 pphp C20A (rigid) & $0.0188 \pm 0.0002$ \\
8 pphp C20A (rigid) & $0.0152 \pm 0.0001$ \\
2 pphp C93A (rigid) & $0.0321 \pm 0.0032$
\end{tabular}

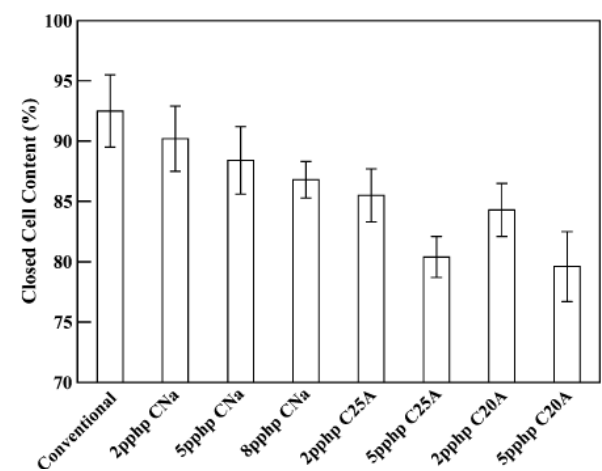

Table 8. Thermal Conductivity of Rigid Foams

\begin{tabular}{lccc}
\hline foam type & $\begin{array}{c}\text { clay in foam } \\
(\mathrm{wt} \%)\end{array}$ & $\begin{array}{c}\text { density } \\
\left(\mathrm{kg} / \mathrm{m}^{3}\right)\end{array}$ & $\begin{array}{c}\text { thermal conductivity } \\
(\mathrm{W} / \mathrm{m} \mathrm{K})\end{array}$ \\
\hline conventional & nil & 34.9 & 0.0184 \\
2 pphp CNa & 0.91 & 34.5 & 0.0172 \\
5 pphp CNa & 2.27 & 33.2 & 0.0170 \\
8 pphp CNa & 3.63 & 32.7 & 0.0171 \\
2 pphp C25A & 0.91 & 33.9 & 0.0189 \\
5 pphp C25A & 2.27 & 33.6 & 0.0233 \\
8 pphp C25A & 3.63 & 32.1 & 0.0201 \\
2 pphp C20A & 0.91 & 34.3 & 0.0198 \\
5 pphp C20A & 2.27 & 32.1 & 0.0252 \\
8 pphp C20A & 3.63 & 31.1 & 0.0206
\end{tabular}

FIGURE 2.24.- Some properties of the produced foams: a) Cell window area; b) Open Cell Content; c)

\section{Thermal Conductivity}

Kim et al. $^{42}$ studied the effect of organoclay on the thermal insulating properties of rigid polyurethane foams, using different eco-friendly foaming agents: water, cyclopentane, and HFC-365mfc and HCFC-141b. Organomodified nanoclays employed were Cloisite 30B, which were dehydrated overnight previously to the dispersion (3\%) in the isocyanate with and without the help of ultrasonication. This technique was employed for 15 minutes at a 
temperature of $50 \circ \mathrm{C}$, and nanoparticles were previously pre-dispersed $(3000 \mathrm{rpm})$ in the isocyanate for 2 hours with the help of a mechanical stirrer. Density of the final foams was around $50 \mathrm{~kg} / \mathrm{m}^{3}$. The introduction of nanoclays produced a cell size reduction, regardless of the type of blowing agent employed. Thermal conductivity of the produced foams was smaller for the materials produced with HCFC-141b, and ultrasonication showed also a reduction of this property for all the blowing agents employed (Fig. 2.25). Moreover, the presence of nanoclays produced a thermal conductivity reduction for all the foaming agents. Anyway, three main aspects are missed in this article: a study of the final foam densities, a longer explanation of the morphological changes produced on the cellular structure, and the effect of chemical changes that can be produce in the isocyanate due to the aggressive, long term nanoclays-isocyanate mixing (e.g. isocyanurate formation ${ }^{36}$ ). In addition, there is no modelling of the thermal conductivity of the foam.

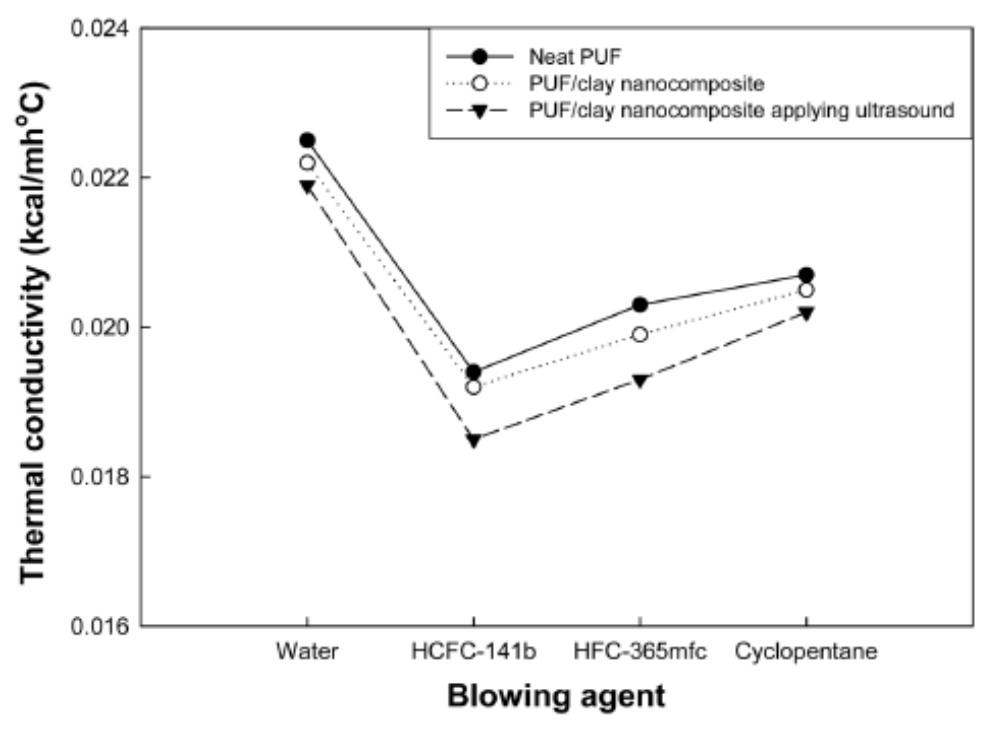

FIGURE 2.25.- Thermal conductivity of neat PUF and PUF/clay nanocomposites with and without applying ultrasound.

Other authors studied changes produced on thermal conductivity by the inclusion of nanoclays, but this subject was not the main objective of their study. Kim, Lee et al. ${ }^{112}$ produced rigid polyurethane foams with clays $(0.5,1,2$ and $4 \% \mathrm{wt})$ which were intercalated and exfoliated by neutralized dimethyol butanoic acid (DMBA). Blowing agent employed was HFC $365 \mathrm{mfc}$. The main objective of this article was a complete characterization of the effect of this new organo-modification over the final foams, and between the different characteristics studied thermal conductivity and cell size were included, only some SEM images (see Fig. 2.26). A minimum for both characteristics was observed for $2 \%$ nanoclays concentration, obtaining an approximately $3 \%$ reduction with respect to pure material. No quantitative analysis of the 
cell sizes was made. Although this is not the general purpose of the research, once again a detailed study of the cellular structure and thermal conductivity is missed.

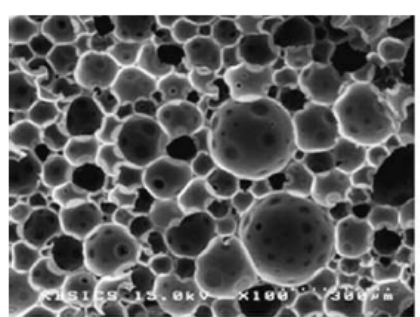

(a)N00

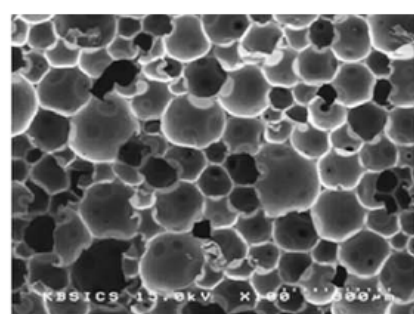

(b)N05

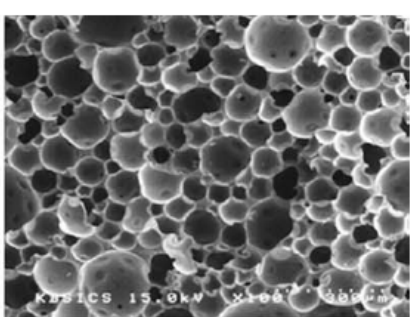

(c)N10

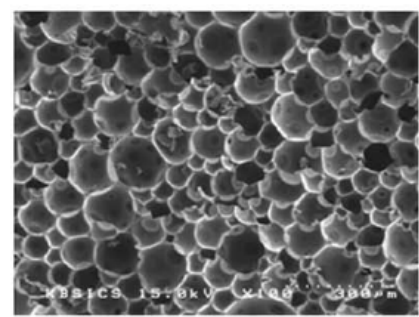

(d) N20

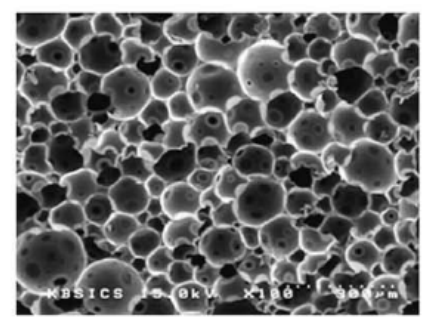

(e) N40

FIGURE 2.26.- SEM morphology of PUF/clay nanocomposites vs clay content

Harikrishnan et al. ${ }^{45}$ studied nanodispersions of clays in polyurethane components, both natural and organically modified nanoclays of various aspect ratios in $8 \%$ concentration. The dispersion technique employed was ultrasonication for 24 hours, with a previous mechanical stirring of 1 hour. The percentage change in the thermal conductivity of foams after accelerated aging was studied (Fig. 2.27), with the best results for the natural vermiculite, which is the particle with the higher aspect ratio of all studied nanoparticles. Anyway, absolute values of thermal conductivity are missed, together with density values.

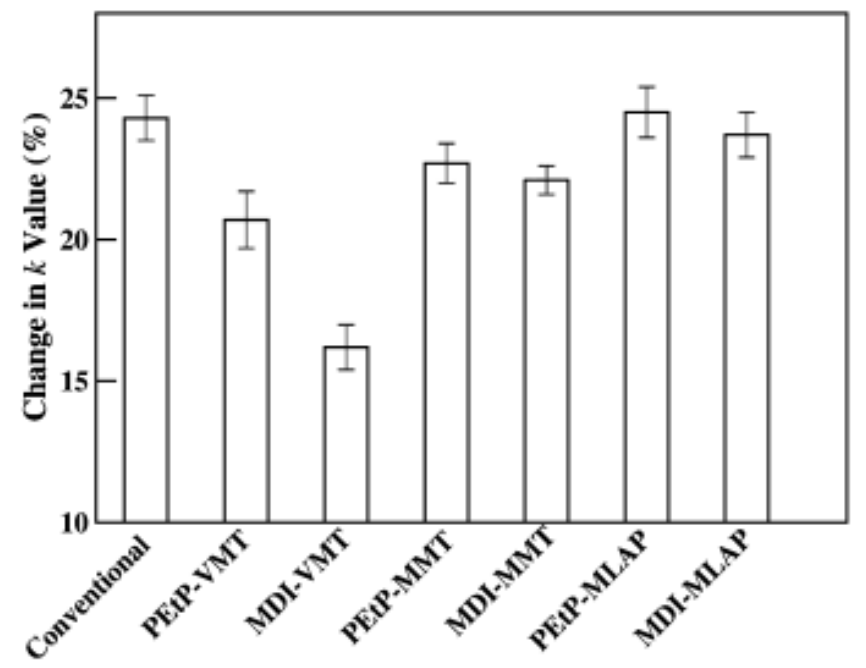

FIGURE 2.27.- Change in the thermal conductivity with accelerated aging of conventional and nanocomposite foams 
Danowska et $\mathrm{al}^{102}$ investigate the effect of three different nanofillers on the properties of rigid polyurethane foams. The reaction mixture consisted of the proper amounts of the commercial oligoether polyol, catalysts, water, nanoclays, and polymeric diphenylmethane diisocyanate. Three types of montmorillonite were used: Cloisite 30B, Laponite RD, and Bentonite. Thermal properties of rigid polyurethane foams and nanocomposite foams were investigated by dynamical thermal analysis, thermogravimetry, oxygen index, and thermal conductivity measurements, obtaining in the case of thermal conductivity an increase of this property in all the cases with exception of the 3\% cloisite 30B foams. In this case a $20 \%$ reduction was observed, and it was explained taking into account the cell size reduction by the nanoclays addition (around 18\% reduction). But also a significant change was observed in the density, passing from $22 \mathrm{~kg} / \mathrm{m}^{3}$ for pure material to $33 \mathrm{~kg} / \mathrm{m}^{3}$ in the case of $3 \%$ cloisite $30 \mathrm{~B}$ foams (Table 2.5).

TABLE 2.5.- Foaming and Physical Properties of the Foam Samples

\begin{tabular}{|c|c|c|c|c|c|c|c|c|}
\hline \multirow[b]{2}{*}{$\begin{array}{l}\text { Sample } \\
\text { code }\end{array}$} & \multicolumn{4}{|c|}{ Foaming properties } & \multicolumn{4}{|c|}{ Physical properties } \\
\hline & $\begin{array}{l}\text { Start } \\
\text { time (s) }\end{array}$ & $\begin{array}{l}\text { Growth } \\
\text { time (s) }\end{array}$ & $\begin{array}{l}\text { Gelation } \\
\text { time (s) }\end{array}$ & $\begin{array}{l}\text { Max. temperature } \\
\text { of foaming } \\
\text { process }\left({ }^{\circ} \mathrm{C}\right)\end{array}$ & $\begin{array}{l}\text { Apparent } \\
\text { density } \\
\left(\mathrm{kg} \mathrm{m}^{-3}\right)\end{array}$ & $\begin{array}{l}\text { Water } \\
\text { absorption } \\
\text { (\%) }\end{array}$ & $\begin{array}{l}\text { Brittleness } \\
\text { (mass loss, \%) }\end{array}$ & $\begin{array}{l}\text { Thermal } \\
\text { conductivity } \\
\left(\mathrm{mW} \mathrm{mK}^{-1}\right)\end{array}$ \\
\hline$P_{0}$ & 10 & 46 & 64 & 125.7 & $21.7 \pm 2.0$ & $85 \pm 3$ & $17 \pm 2$ & $26.1 \pm 1.3$ \\
\hline $\mathrm{P}_{3 \% \mathrm{Clo}}$ & 10 & 60 & 70 & - & $33.4 \pm 3.0$ & $50 \pm 1$ & $27 \pm 3$ & $21.1 \pm 1.0$ \\
\hline $\mathrm{P}_{6 \% \mathrm{Clo}}$ & 10 & 60 & 81 & 155.0 & $34.4 \pm 4.0$ & $89 \pm 3$ & $33 \pm 2$ & $26.3 \pm 1.3$ \\
\hline $\mathrm{P}_{9 \% \mathrm{Clo}}$ & 10 & 81 & 116 & - & $56.4 \pm 5.0$ & $123 \pm 4$ & $42 \pm 4$ & $38.4 \pm 1.9$ \\
\hline$P_{3 \% R D}$ & 13 & 61 & 123 & - & $32.4 \pm 3.0$ & $90 \pm 5$ & $10 \pm 1$ & $27.1 \pm 1.4$ \\
\hline$P_{6 \% R D}$ & 15 & 80 & 180 & 116.6 & $33.5 \pm 3.1$ & $78 \pm 2$ & $28 \pm 2$ & $26.2 \pm 1.3$ \\
\hline$P_{9 \% R D}$ & 15 & 130 & 390 & - & $32.6 \pm 2.9$ & $132 \pm 4$ & $60 \pm 3$ & $32.3 \pm 1.6$ \\
\hline $\mathrm{P}_{3 \% \text { Ben }}$ & 13 & 68 & 123 & - & $25.4 \pm 2.0$ & $106 \pm 3$ & $33 \pm 2$ & $27.6 \pm 1.4$ \\
\hline$P_{6 \% \text { Ben }}$ & 14 & 73 & 180 & 89.8 & $23.9 \pm 2.2$ & $138 \pm 4$ & $25 \pm 2$ & $39.1 \pm 2.0$ \\
\hline $\mathrm{P}_{9 \% \text { Ben }}$ & 15 & 121 & 256 & - & $22.8 \pm 2.0$ & $188 \pm 5$ & $35 \pm 3$ & $42.4 \pm 2.1$ \\
\hline
\end{tabular}

Two main conclusions can be obtained by the study of the state of the art in the cellular structure and thermal conductivity of rigid polyurethane foams infused with nanoclays:

- A cell size reduction is produced by the inclusion of nanoclays in polyurethane rigid foams. This reduction is usually explained by a reduction of the free surface energy by the exfoliated clays that produces an increase of the nucleation sites. As the amount of nucleation centers increases, the bubble size decreases and the number of cells increase. This effect is growth with the amount of nanoparticles typically reaching a minimum.

- A reduction of the thermal conductivity, conditioned to a non-increase of the open cell percentage.

Anyway, these studies do not analyse in detail the cellular structure of the materials, the different mechanisms involved in the thermal conductivity and their weight on the final 
conductivity value. A deeper analysis of the nanoclays effect over these different heat conduction mechanisms could help to elaborate better models to predict the behaviour of these foamed nanocomposites.

\subsubsection{Mechanical Properties}

Facing the shortage of references available related with the thermal conductivity of rigid polyurethane foams infused with nanoparticles, a great number of studies are referred to mechanical properties. In the different studies found in the literature the introduction of nanoclays has produced mainly a decrease of the mechanical properties, but in some cases an increase has been also observed. The most relevant publications are described below.

First, we will review some selected publications on which a reduction of the mechanical properties was detected. Cao et al. ${ }^{46}$ observed a reduction of the mechanical properties for the rigid foams in the study of polyurethane-montomorillonite composites. To exclude the density difference of the foam samples, the compressive strength and modulus divided by the density of the foam sample were used to compare the mechanical properties of the PU foams with different clays. As it has been commented on section 2.1.2, the relationship between mechanical properties and density is given by Gibson and Ashby law ${ }^{1}$, and for these density ranges, the relationship was not usually lineal. Anyway, considering a mechanical dependence respect to the square of the density, no improvement is observed. Also, a possible interaction mechanism between the existing H-bonds between urethane groups (Fig. 2.28 (a)) and the functionalizated nanoclays was postulated. Lorenzetti et al. ${ }^{103}$, in the study of alternative dispersion techniques for nanoclays in rigid polyurethane foams, concretely microwave dispersion (see section 2.4.2), observed a good dispersion and a reduction of the required dispersion time compared with ultrasonication, but also, they observed a reduction in the mechanical performance due to a clay interference with $\mathrm{H}$-bond formation (Fig. 2.28 (b)).

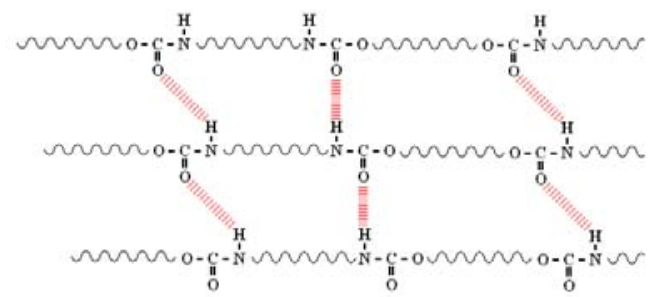

(a)

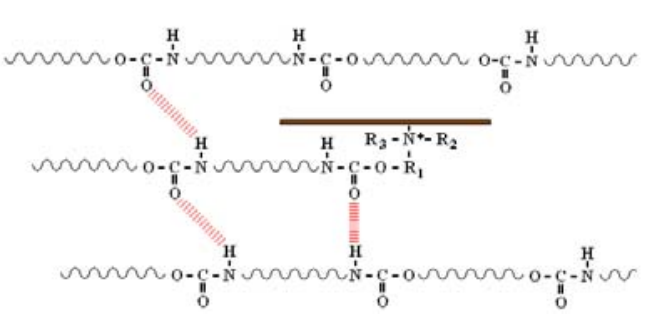

(b)

FIGURE 2.28 (a) Pure polyurethane structure: urethane groups and H-bonds; (b) Polyurethane infused with functionalized nanoclays: urethane groups, $\mathrm{H}$-bonds and nanoclays. 
Then, an important conclusion of these papers is that the mechanical properties of PU nanocomposite foams depend on the competition between the positive reinforcing effect of clay and the negative effect related with hindering the $\mathrm{H}$-bond formation.

Widya and Mackosko ${ }^{39}$ incorporated different montmorillonite based organoclay concentrations (1, 2, 3 and 5\%wt, Cloisite 30B nanoclay) into rigid polyurethane foams with ultrasonication dispersion, and studied the effect of these particles on different physical properties of polyurethane foams. Isocyanate index was varied from 200 to 300 . A cell size reduction and cell number increase was observed even for the lower nanoclays concentration, but clay loading did not result in increased mechanical strength of the rigid PU foams. Foams produced with higher isocyanate index had higher compression strength and modulus, due to the presence of more isocyanurate hard segments. However, the strength and modulus decreased with clay loading for the 250-index. The presence of clay may interfere with isocyanurate formation, resulting in a weaker chemical structure of the foam. In the case of the 300-index samples, there were a reduction in compression strength and modulus despite the decrease in cell size from 0.40 to $0.28 \mathrm{~mm}$.

Contrarily to these results, $\mathrm{Xu}$ et al. ${ }^{95}$ obtained a clear improvement of the mechanical properties during the study of a novel method for preparing rigid polyurethane foam infused with nanoclays (pure and organomodified) composites. Organomodified nanoclays employed presented one-tail octadecyl primary ammonium, which were dehydrated overnight previously to the dispersion in the polyol with the help of ultrasonication. This technique was employed for two hours at a temperature of $50^{\circ} \mathrm{C}$, and nanoparticles were previously pre-dispersed in the polyol for 2 minutes with the help of a mechanical stirrer. The new method introduced in the study is the absence of any physical or chemical blowing agent in the production of nanoclays infused foams. The resultant foams with an appropriate content of the organoclay had a finer cell structure than the pristine PU foams because the organoclay not only acted as a nucleating agent as expected but also acted as a blowing agent of the PU foams; this could be attributed to the bound water between the interlayers of the organoclay. The organoclay content had a remarkable effect on the compressive and tensile strengths of the nanocomposites. Both the compressive strength and tensile strength were increased dramatically even with a small addition of the organoclay and reached the maximum value at 2 phr organoclay (around a 152\% increase in the compressive strength and a 110\% increase in the tensile strength in comparison with the pure PU foams). This result is quite different from those obtained by other researchers (see previous paragraph) that have suggested no 
enhancement or even a decrease in the mechanical behavior of rigid PU foam-organoclay nanocomposites.

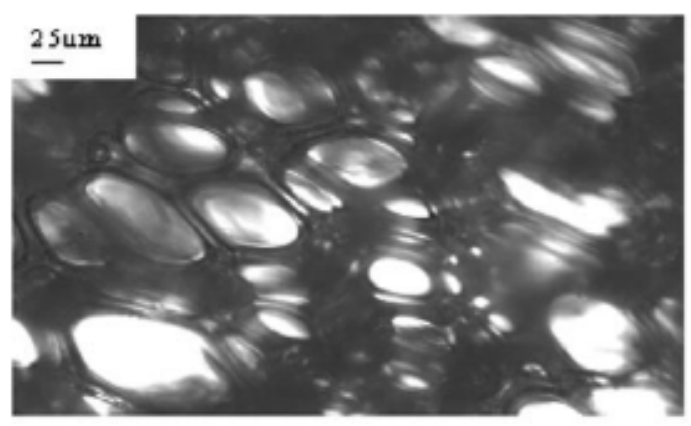

(a) pristine $\mathrm{PU}$

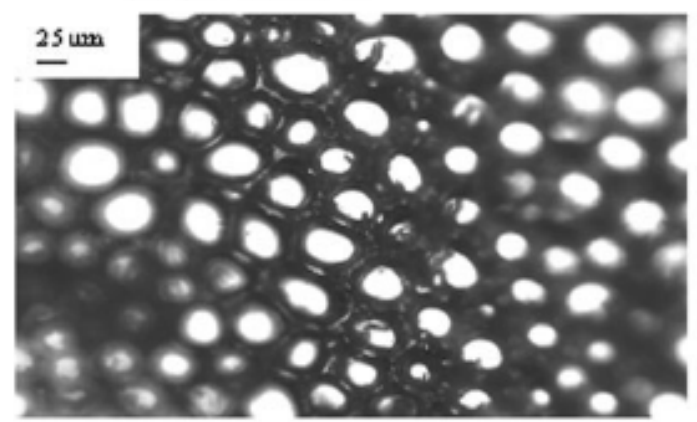

(c) PU/clay 2

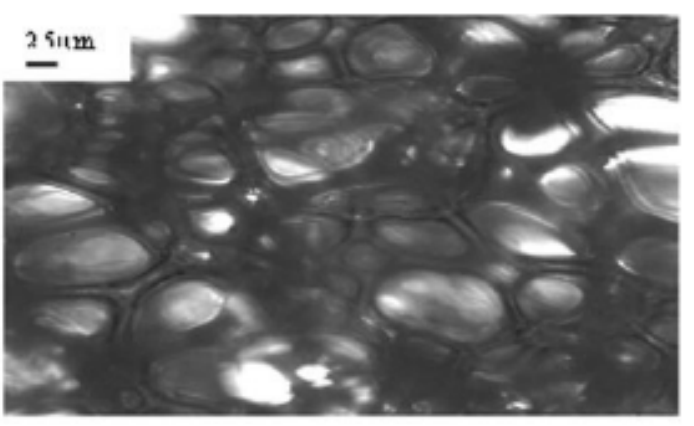

(b) PU/clay 1

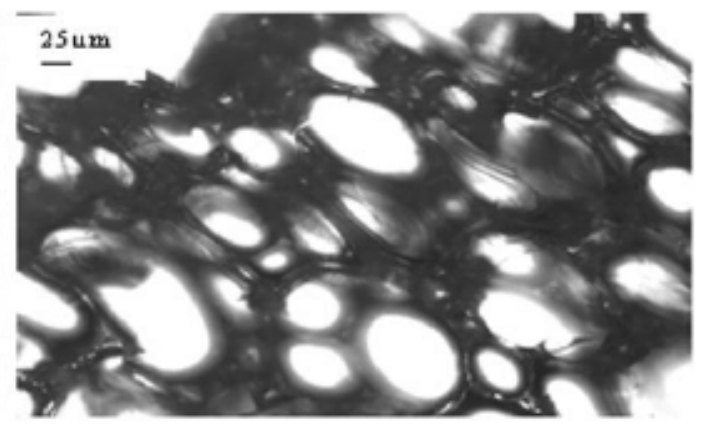

(d) PU/clay 4

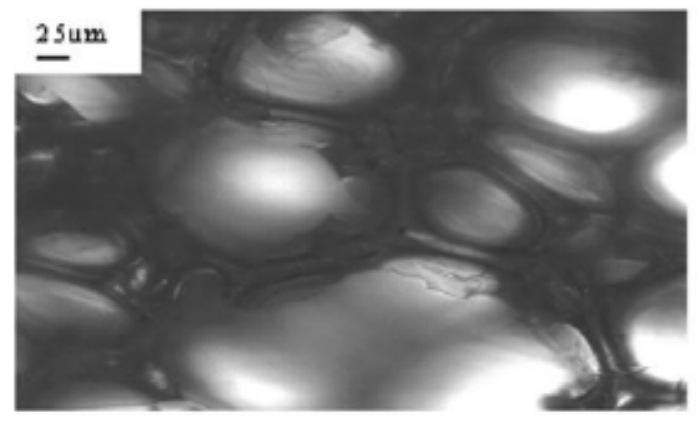

FIGURE 2.29.- Polarized optical microscopy images of the pristine PU foams and rigid PU foam/organoclay nanocomposites from Xu et al. ${ }^{95}$ study

$\mathrm{Xu}$ et al. suggested that two factors can explain this difference: (1) the increased internal strength of the PU matrix due to the higher degree of hydrogen bonding among the urethane groups and (2) the finer cell structure of the nanocomposites. With a finer and more uniform cell structure, rigid PU foam/organoclay nanocomposites could withstand higher stresses. Anyway, it is remarkable that the density values are not included. Due to the high dependence of mechanical properties with density ${ }^{1}$ and the possible changes in density related to the nanoclays inclusion (see section 2.4.1), a detailed study of density could have helped to a better understanding of the observed improvements. Anyway, on Fig. 2.29 optical images 
show that 2 phr organoclay samples possibly present the higher density, which explains the increase of the mechanical strength.

Danowska et $\mathrm{al}^{102}$ also observed and increase of the mechanical properties by nanoclays addition to rigid polyurethane foams. As it has been mentioned in the previous section, the effect of three different nanofillers on the properties of rigid polyurethane foams were investigated, with three types of montmorillonites: Cloisite 30B, Laponite RD and Bentonite. Great improvements were reported for mechanical properties, concretely a $300 \%$ for the compression strength in the case of $9 \%$ Cloisite 30B foams. However, as in the thermal properties, a large change was observed in the density, passing from $22 \mathrm{~kg} / \mathrm{m}^{3}$ for pure material to $56 \mathrm{~kg} / \mathrm{m}^{3}$ in the case of $9 \%$ cloisite $30 \mathrm{~B}$ foams, which could be the main origin of these differences. Some calculus can be made accepting the Gibson and Ashby relationship ${ }^{1}$ between mechanical properties and density presented in section 2.1.2. Taking an $n$ value equal to 2 , the initial increase of the nanoreinforced material is actually a decrease: $200 \mathrm{~Pa} \cdot \mathrm{m}^{6} / \mathrm{kg}^{2}$ is the value of the compression strength relative to the squared density for the pure material and $94 \mathrm{~Pa} \cdot \mathrm{m}^{6} / \mathrm{kg}^{2}$ is the value of the same property for the $9 \%$ cloisite $30 \mathrm{~B}$ foams.

Liang and $\mathrm{Shi}^{98}$ studied polyurethane foams fabricated from polymeric diphenylmethane diisocyanate (pMDI) and soybased polyol, infused with nanoclay Cloisite 30B ( 0.5 to $3 \%$ wt.). Nanoclays inclusion improved the compressive strength and modulus of the polyurethane foams. The compressive strength and modulus of nanoclay polyurethane foams were first increased with nanoclays loading at $0.5 \mathrm{php}$, then decreased as the nanoclays loading increased. At $0.5 \mathrm{php}$ nanoclay the compressive strength and modulus were increased by 98 and 26\%, respectively, as compared to the neat soy-based polyurethane foam. This increase is explained by the authors as a result of the higher density (from around 0.195 to $0.205 \mathrm{~kg} / \mathrm{m}^{3}$ ) and smaller cell size of foam composites; the authors also explain that it was easier to disperse uniformly the nanoclays into polyol resin at a low loading, resulting in more uniform and smaller cell size. However, the viscosity of nanoclay polyol mixture was higher at high nanoclay loading which made more difficult to disperse the nanoparticles. This would cause less uniform and some larger cell size due to the excessive coalescene. Thus, the compressive strength and modulus of nanoclay soybased polyurethane foam decreased when the nanoclays loading increased.

In a Kim et al. ${ }^{42}$ paper, previously discussed on the thermal properties section, an increase of the mechanical properties was also observed. In this paper it was studied the effect of organoclay on the thermal insulating properties of rigid polyurethane foams, using different eco-friendly foaming agents. Organomodified nanoclays employed were Cloisite 30B, in a 3 
$\% w t$. concentration, dispersed with and without the help of ultrasonication technique. Density of the final foams was set at $50 \mathrm{~kg} / \mathrm{m}^{3}$. Between the foaming agents employed, water produced the foams with highest tensile strength, property which also was better for nanocomposites respect to pure materials, and between nanocomposites those that were made with the help of ultrasonication were better too. No explanation to this increase is given; only best performance of ultrasonication nanocomposites is explained by a possible best dispersion. The increase with respect to pure material is high, around $30 \%$ for cyclopentane foamed nanocomposites (passing from $0.35 \mathrm{MPa}$ to $0.45 \mathrm{MPa}$ of tensile strength). The best results are obtained for water foamed nanocomposites, with a $20 \%$ increase with respect to pure material, passing from 0.5 MPa to 0.6 MPA

Zhu et $\mathrm{al}^{108}$ produced water-blown, cellulose microfibers and nanoclays (pure and organo-modified; $2 \% \mathrm{wt}$ ) reinforced rigid polyurethane foams from soy-based polyol, studying their structure-property correlations. Morphology, mechanical, and thermal properties of final foams were characterized. Physical properties of foams, including density and compressive strength, were also determined. The cellular morphologies of foams were analyzed by SEM and $\mathrm{X}$-ray micro-CT and revealed that incorporation of microfibers and nanoclays into foam altered the cellular structure of the foams, reducing the average cell size. Foam with Cloisite 93A had the smallest cell sizes and maximum number of small cells and provided the highest compressive strength. Similarly with other nanoclays, the compressive strength improvements followed the trend in accordance with cell sizes and their distributions. Moreover a considerable increase of the density was also observed in some cases, although in the case of cloisite $93 \mathrm{~A}$ similar densities were produced (around $80 \mathrm{~kg} / \mathrm{m}^{3}$ ), and a $50 \%$ of increase in the compressive strength was observed. Anyway, the analysis of additional mechanical properties (e.g. Young's modulus) could have helped to confirm these improvements.

Finally, it is possible to conclude from the review of the different changes produced in the mechanical properties by nanoclays that the more usual result is a reduction of the final mechanical properties. In those papers in which an increase of these properties have been observed a detailed study of density is not included. A possible interaction mechanism between the existing $\mathrm{H}$-bonds linking urethane groups and the functionalized nanoclays is the most proposed explanation of those mentioned in the literature for the reduction of the mechanical properties when the clays are infused. Only in the soy-based polyols a clear increase has been produced by the nanoclays inclusion. In these papers the only increase of density does not completely explains the observed changes. 
Chapter 2: Background and State of the Art

\subsubsection{Conclusions}

Although the study of the different papers published to date in the field of polyurethane foams infused with nanoclays has shown a high variety of results and characterization techniques, a more systematic study of these materials is missed. Some aspects, like the cellular structure, the dispersion, the modelling of the different properties and so on must be taken into account to obtain a better understanding of these cellular materials and the changes produced in their properties.

The present work considers all these aspects and presents a deeper study of polyurethane-nanoclays foams than those papers previously studied. The study is mainly focused on:

1. Evaluating in detail the effect of the dispersion quality of the nanoclays in the polyol component on the structure and properties of polyurethane foams filled with nanoclays.

2. Evaluating in detail the effect of the clays content on the cellular structure, thermal and mechanical properties of the foamed nanocomposites.

3. Improving the thermal conductivity of polyurethane foams by using nanoclays as nucleating agent and IR-blocker.

4. Modelling the thermal conductivity of the developed foams, using as a basis a detailed characterisation of the different materials and the experimental determination of the extinction coefficient. 
${ }^{1}$ L. J. Gibson, M. F. Ashby, Cellular solids: structure and properties, Pergamon Press, Oxford, (1988)

${ }^{2}$ D. Klempner, V. Sendijarevic, Handbook of polymeric foams and foam technology, Munich: Hanser Publishers, (2004)

${ }^{3}$ D. Randall, S. Lee, The polyurethanes book, J.Wiley, (2002)

${ }^{4}$ ASTM D3576-04. Standard test method for cell size of rigid cellular plastics. Annual Book of ASTM Standards, Vol 8.02, (2011)

5 J. Pinto, E. Solórzano, M. A. Rodriguez-Perez, J. A. de Saja, Characterization of the cellular structure based on user-interactive image analysis procedures, Journal of Cellular Plastics, 49(6), 555-575 (2013)

${ }^{6}$ M.A. Rodríguez-Pérez, J. Lobos, C.A. Pérez-Muñoz, J.A. de Saja, Mechanical Behaviour at Low Strains of LDPE Foams with Cell Sizes in the Microcellular Range: Advantages of Using these Materials in Structural Elements, Cellular Polymers 27(6), 347-362, (2008)

7 M.A. Rodríguez-Pérez, J. Lobos, C.A. Pérez-Muñoz, J.A. de Saja, Mechanical Response of Polyethylene Foams with High Densities and Cell Sizes in the Microcellular Range, Journal of Cellular Plastics, 45(5), 389-403, (2009)

${ }^{8}$ J.E. Weller, V. Kumar, Solid State Microcellular Polycarbonate Foams. II. The Effect of Cell Size on Tensile Properties, Polymer Engineering and Science 50(11), 2170-2175, (2010)

${ }^{9}$ S. T. Lee, C. B. Park, N. S. Ramesh, Polymeric Foams: Science and Technology, CRC Press, Boca Raton-Florida, (2007)

${ }^{10}$ S.T. Lee, Foam Extrusion: Principles and Practice, Technomic Publishing Company, LancasterPennsylvania, (2000)

${ }^{11}$ D. Eaves, Handbook of Polymer Foams, Rapra Technology, United Kingdom, (2004).

12 M.A. Rodríguez-Pérez, O. Alonso, A. Duijsens, J.A. de Saja, Thermal Expansion of Crosslinked Closed-Cell Polyethylene Foams, Journal of Applied Polymer Science 36(14), 2587-2596, (1998)

${ }^{13}$ W. Gong, J. Gao, M. Jiang, L. He, J. Yu, J. Zhu, Influence of Cell Structure Parameters on the Mechanical Properties of Microcellular Polypropylene Materials, Journal of Applied Polymer Science 122(5), 2907-2914, (2011)

${ }^{14}$ ASTM D6226 - 10: Standard Test Method for Open Cell Content of Rigid Cellular Plastics, ICS Number Code 83.080.01 (Plastics in general), DOI: 10.1520/D6226-10

${ }^{15}$ L.R. Glicksman, Heat Transfer in Foams, in Low Density Cellular Plastics-Physics of Basics of Behaviour, Chapman and Hall, London, pp 107-111, (1994)

${ }^{16}$ M.A. Rodríguez-Pérez, Propiedades Térmicas y Mecánicas de Espumas de Poliolefinas, Thesis, University of Valladolid, (1999)

17 S. Semenzato, A. Lorenzetti, M. Modesti, E. Ugel, D. Hrelja, S., Besco, R. Bertani, A novel phosphorus polyurethane FOAM/montmorillonite nanocomposite: Preparation, characterization and thermal behaviour, Applied Clay Science, 44(1), 35-42, (2009) 
${ }^{18}$ V. Kumar, Microcellular Polymers: Novel Materials for $21^{\text {st }}$ Century, Progress in Rubber and Plastics Technology 9: 54-70, (1993)

19 J. Kuhn, H. P. Ebert, M. C. Arduini-Schuster, D. Büttner, J. Fricke, Thermal transport in polystyrene and polyurethane foam insulations, International Journal of Heat and Mass Transfer, 35(7), 1795-1801, (1992)

${ }^{20}$ A. G. Leach, The thermal conductivity of foams. I. Models for heat conduction, Journal of Physics D: Applied Physics, 26 (5), 733, (1993)

${ }^{21}$ P. G. Collishaw, J. R. G. Evans, An assessment of expressions for the apparent thermal conductivity of cellular materials, Journal of Materials Science, 29(9), 2261-2273, (1994)

${ }^{22}$ M.A. Rodríguez-Pérez, O. Alonso, J. Souto, J. A. De Saja, Thermal conductivity of physically crosslinked closed cell polyolefin foams, Polymer Testing, 16(3), 287-298, (1997)

${ }^{23}$ G. W. Ball, Proceedings IOM Polyurethanes Conf, 10, 257, (1994)

${ }^{24}$ A. Cunningham, D. Sparrow, Rigid polyurethane foam: What makes it the most effective insulant?, Cellular polymers, 5(5), 327-342, (1986)

${ }^{25}$ C. J. Tseng, M. Yamaguchi, T. Ohmori, Thermal conductivity of polyurethane foams from room temperature to $20 \mathrm{~K}$, Cryogenics, 37 (6), 305-312, (1997)

${ }^{26}$ O. A. Almanza, M. A. Rodríguez-Pérez, J. A. De Saja, Prediction of the radiation term in the thermal conductivity of crosslinked closed cell polyolefin foams, Journal of Polymer Science Part B: Polymer Physics, 38(7), 993-1004, (2000)

${ }^{27}$ S. Pardo-Alonso, E. Solórzano, L. Brabant, P. Vanderniepen, M. Dierick, L. Van Hoorebeke, (3d) Analysis of the Progressive Modification of the Cellular Architecture in Polyurethane Nanocomposite Foams via X-Ray Microtomography, European Polymer Journal, 49(5), 9991006, (2013)

${ }^{28}$ R. Siegel; J. R. Howell, In Thermal Radiation Heat Transfer; Taylor \& Francis: London, (1992)

${ }^{29}$ S. Pavlidou, C.D. Papaspyrides, A review on polymer-layered silicate nanocomposites, Progress in polymer science, 33(12), 1119-1198, (2008)

${ }^{30}$ D. Baillis, M. Arduini-Schuster, J. F. Sacadura, Identification of spectral radiative properties of polyurethane foam from hemispherical and bi-directional transmittance and reflectance measurements, Journal of Quantitative Spectroscopy and Radiative Transfer, 73(2), 297-306, (2002)

${ }^{31}$ R. Leppkes, Polyurethanes, material with many faces, Verlag Moderne Industrie AG; $4^{\text {th }}$ edition, (2004)

${ }^{32}$ R. Herrington, K. Hock, Flexible Polyurethane Foams, 2nd Ed., The Dow Chem Company, (1998)

${ }^{33}$ S. S. Narine, X. Kong, L. Bouzidi, P. Sporns, Physical properties of polyurethanes produced from polyols from seed oils: I. Elastomers, Journal of the American Oil Chemists' Society, 84(1), 55-63, (2007) 
34 D. Niyogi, R. Kumar, K. S. Gandhi, Water blown free rise polyurethane foams, Polymer Engineering \& Science, 39(1), 199-209, (1999)

${ }^{35}$ S. A. Baser, D. V. Khakhar, Modeling of the Dynamics of Water and R-11 blown polyurethane foam formation, Polymer Engineering \& Science, 34(8), 642-649, (1994)

${ }^{36}$ M. Modesti, A. Lorenzetti, An experimental method for evaluating isocyanate conversion and trimer formation in polyisocyanate-polyurethane foams, European polymer journal, 37(5), 949-954, (2001)

${ }^{37}$ K. C. Frisch, V. Sendijarevic et al., Proceeding of Polyurethane World Congress 1991, Nice, p. 850-5, (1991)

${ }^{38}$ C. Chittolini, Proceeding of Polyurethane World Congress 1997, Amsterdam, p. 655-9, (1997)

39 T. Widya, C. W. Macosko, Nanoclay-modified rigid polyurethane foam. Journal of Macromolecular Science, Part B: Physics, 44(6), 897-908, (2005)

${ }^{40}$ D. Gerber, J. R. Derluyn, E. Huygens, U.S. Patent No. 5,521,225, Washington, DC: U.S. Patent and Trademark Office, (1996)

${ }^{41}$ M. Modesti, A. Lorenzetti, S. Besco, Influence of nanofillers on thermal insulating properties of polyurethane nanocomposites foams, Polymer Engineering \& Science, 47(9), 1351-1358, (2007)

${ }^{42}$ Y. H. Kim, S. J. Choi, J. M. Kim, M. S. Han, W. N. Kim, K. T. Bang, Effects of organoclay on the thermal insulating properties of rigid polyurethane foams blown by environmentally friendly blowing agents, Macromolecular Research, 15(7), 676-681, (2007)

${ }^{43}$ M. Thirumal, D. Khastgir, N. K. Singha, B. S. Manjunath, Y. P. Naik, Effect of foam density on the properties of water blown rigid polyurethane foam, Journal of Applied Polymer Science, 108(3), 1810-1817, (2008)

${ }^{44}$ S. N. Singh, Blowing agents for polyurethane foams (Vol. 12), iSmithers Rapra Publishing, (2002)

45 G. Harikrishnan, C. I. Lindsay, M. A. Arunagirinathan, C. W. Macosko, Probing Nanodispersions of Clays for Reactive Foaming, ACS applied materials \& interfaces, 1(9), 19131918, (2009)

46 X. Cao, L. J. Lee, T. Widya, C. Macosko, Polyurethane/clay nanocomposites foams: processing, structure and properties, Polymer, 46(3), 775-783, (2005)

47 G. Harikrishnan, T. U. Patro, D. V. Khakhar, Polyurethane foam-clay nanocomposites: nanoclays as cell openers, Industrial \& Engineering Chemistry Research, 45(21), 7126-7134, (2006)

48 S. Lee, et al., Zero Ozone-Depleting Foaming Agent Technology for Extruded Polystyrene Foam, FOAMS 2009 Conference, Iselin, NJ (2009)

${ }^{49}$ Costeux, Foams 2010 conference paper, (2010)

${ }^{50}$ http://www.ipcc.ch/publications_and_data/ar4/wg1/en/tssts-2-5.html 
${ }^{51}$ DEFRA, Disposing of fridges and refrigeration equipment, Department for Environment, Food and and Rural Affairs (UK) (2003)

52 T. Herrera, GE to cut manufacturing plant's emissions by $80 \%$, GreenBiz.com (2011). http://www.greenbiz.com/news/2011/04/29/ge-cut-manufacturingplants-emissions-80percent?utm_source $1 / 4$ GreenBuzz\&utm_campaign $1 \frac{1}{4}$ a0c54d5a62-GreenBuzz-2011-0502\&utm_medium $1 / 4$ email

53 EPA., Substitutes in rigid polyurethane, Appliance (2009). http://www.epa.gov/ozone/snap/foams/lists/applianc.html (Washington DC)

${ }^{54}$ R. Fleischer, Advances in environmentally sustainable refrigerants and blowing agents, 5th International conference on Energy Efficiency in Domestic Appliances and Lighting (EEDAL'09), http://www.eedal.eu/index.php?id1/411575, Berlin, June 16e18, (2009)

${ }^{55}$ B. Chen, J. Costa, P. Bonnet, M. Elsheikh, L. Abbas, Investigation of low GWP blowing agents, Appliance Magazine, January 2009, http://www.applianceMagazine.com (2009)

${ }^{56}$ C. V. Vo, R. T. Fox, Assessment of Unsaturated Fluorocarbons as Insulating Blowing Agents For Extruded Polystyrene Foams, Foams 2012 conference paper, (2012)

${ }^{57}$ Formacel. http://www2.dupont.com/Formacel/en_US/index.html (2011)

${ }^{58} \mathrm{http} / / /$ www.epa.gov/ozone/snap/foams/lists/comm.html

59 C. Torres-Sánchez, J. Corney, Identification of formation stages in a polymeric foam customised by sonication via electrical resistivity measurements, Journal of Polymer Research, 16(5), 461-470, (2009)

${ }^{60}$ D. Niyogi, R. Kumar, K. S. Gandhi, Water blown free rise polyurethane foams, Polymer Engineering \& Science, 39(1), 199-209, (1999)

${ }^{61}$ G. Woods, The ICl Polyurethanes Book, 2nd ed., Wiley, New York, p. 1, (1990)

62 Z. Wirpsza, Polyurethanes: Chemistry, Technology, and Applications, Ellis Horwood, New York, p. 3, (1993)

${ }^{63}$ W. D. Callister, D. G. Rethwisch, Fundamentals of Materials Science and Engineering: An Integrated Approach, 3rd Edition, pp. 111, 561-563, (2008)

${ }^{64}$ H.R.N. Jones, In Radiation Heat Transfer, Oxford Science: Oxford, (2000)

65 D. Baillis, J.F. Sacadura, Thermal radiation properties of dispersed media: theoretical prediction and experimental characterization, Journal of Quantitative Spectroscopy and Radiative Transfer, 67(5), 327-363, (2000)

${ }^{66} \mathrm{~J}$. W. Wu, W. F. Sung, H.S. Chu, Thermal conductivity of polyurethane foams, International journal of heat and mass transfer, 42 (12), 2211-2217, (1999)

${ }^{67}$ A. Usuki, M. Kawasumi, Y. Kojima, A. Okada, T. Kurauchi, O. J. Kamigaito, Swelling Behavior of Montmorillonite Cation Exchanged for V-amino Acids by E-caprolactam, Journal of Materials Research, 8 (5): 1174, (1993) 
${ }^{68}$ C. O. Oriakhi, Nano Sandwiches, Chemistry in Britain , 34(11), 59-62, (1998)

${ }^{69}$ L. J. Lee, C. Zeng, X. Cao, X. Han, J. Shen, G. Xu, Polymer nanocomposite foams, Composites Science and Technology, 65(15-16), 2344-2363, (2005)

${ }^{70}$ R. Verdejo, C. Saiz-Arroyo, J. Carretero-Gonzalez, F. Barroso-Bujans, M.A. Rodriguez-Perez, M.A. Lopez-Manchado, Physical properties of silicone foams filled with carbon nanotubes and functionalized graphene sheets, European Polymer Journal 44(9), 2790-2797 (2008)

${ }^{71}$ J.I. Velasco, M. Ardanuy, V. Realinho, M.Antunes, A.I. Fernández, J.I. González-Peña, M.A. Rodríguez-Pérez, J.A. de Saja, Polypropylene/clay nanocomposites: combined effects of clay treatment and compatibilizer polymers on the structure and properties, Journal of Applied Polymer Science 102(2), 1213-1223 (2006)

${ }^{72}$ W. Zheng, S. C. Wong, Electrical conductivity and dielectric properties of PMMA/expanded graphite composites, Composites Science and Technology, 63(2), 225-235, (2003)

${ }^{73}$ M. Modesti, A. Lorenzetti, S. Besco, D. Hrelja, S. Semenzato, R. Bertani, R. A. Michelin, Synergism between flame retardant and modified layered silicate on thermal stability and fire behaviour of polyurethane nanocomposite foams, Polymer Degradation and Stability, 93(12), 2166-2171, (2008)

${ }^{74}$ Y. Kojima, A. Usuki, M. Kawasumi, A. Okada, Y. Fukushima, T. Kurauchi, O. J. Kamigaito, Mechanical properties of nylon 6-clay hybrid, Journal of Materials Research, 8(05), 1185. (1993)

75 S. X. Zhou, L. M. Wu, J. Sun, W. D. Shen, Effect of nanosilica on the properties of polyester-based polyurethane, Journal of Applied Polymer Science, 88(1), 189-193 (2003)

76 E. Manias, A. Touny, L. Wu, K. Strawhecker, B. Lu, T. C. Chung, Polypropylene/ montmorillonite nanocomposites, Review of the synthetic routes and materials properties, Chemistry of Materials, 13(10), 3516-23, (2001)

77 I. J. Chin, T. Thurn-Albrecht, H. C. Kim, T. P. Russell, J. Wang, On exfoliation of montmorillonite in epoxy, Polymer, 42(13), 5947-52, (2001)

${ }^{78}$ M. Alexandre, P. Dubois, Polymer-layered silicate nanocomposites: preparation, properties and uses of a new class of materials, Materials Science and Engineering: R: Reports, 28(1), 1$63,(2000)$

${ }^{79}$ G. Bhat, R. H. Hegde, M. G. Kamath, B. Deshpande, Nanoclay Reinforced Fibers and Nonwovens, Journal of Engineered Fibers and Fabrics, 3(3), 22-34 (2008)

${ }^{80}$ R. A. Vaia, S. Vasudevan, W. Krawiec, L. G. Scanlon, E. P. Giannelis, New polymer electrolyte nanocomposites: Melt intercalation of poly (ethylene oxide) in mica-type silicates, Advanced Materials, 7(2), 154-156, (1995)

${ }^{81}$ F. Chivrac, E. Pollet, L. Avérous, Progress in nano-biocomposites based on polysaccharides and nanoclays, Materials Science and Engineering: R: Reports, 67 (1), 1-17, (2009)

82 J.C. Dai, J.T. Huang, Surface modification of clays and clay-rubber composite, Applied Clay Science, 15(1), 51-65, (1999) 
${ }^{83}$ Y. Ke, J. Lü , X. Yi, J. Zhao, Z. Qi, The effects of promoter and curing process on exfoliation behavior of epoxy/clay nanocomposites, Journal of Applied Polymer Science, 78(4), 808-815, (2000)

${ }^{84}$ H.R. Fischer, L.H. Gielgens, T.P.M. Koster, Nanocomposites from polymers and layered minerals, Acta Polymerica, 50 (4), 122-126, (1999)

${ }^{85}$ X. Kornmann, H. Lindberg, L. A. Berglund, Synthesis of epoxy-clay nanocomposites: influence of the nature of the clay on structure, Polymer, 42(4), 1303-10, (2001)

${ }^{86}$ E. P. Giannelis, Polymer layered silicate nanocomposites, Advanced Materials, 8 (1), 29-35, (1996)

${ }^{87}$ C. M. Kim, D. H. Lee, B. Hoffmann, J. Kressler, G. Stoppelmann, Influence of nanofillers on the deformation process in layered silicate/polyamide 12 nanocomposites, Polymer, 42(3), 1095100, (2001)

${ }^{88}$ A. S. Zerda, A. J. Lesser, Intercalated clay nanocomposites: morphology, mechanics and fracture behaviour, Journal of Polymer Science Part B: Polymer Physics, 39(11), 1137-46, (2001)

${ }^{89} \mathrm{H}$. Fischer, Polymer nanocomposites: from fundamental research to specific applications, Materials Science and Engineering: C, 23(6), 763-72, (2003)

90 J. C. Huang, Z. K. Zhu, J. Yin, X. F. Qian, Y. Y. Sun, Poly(etherimide)/montmorillonite nanocomposites prepared by melt intercalation: morphology, solvent resistance properties and thermal properties, Polymer, 42(3), 873-7, (2001)

${ }^{91}$ R. A. Vaia, E. P. Giannelis, Lattice model of polymer melt intercalation in organically-modified layered silicates, Macromolecules, 30(25), 7990-7999, (1997)

${ }^{92}$ H. Bahrambeygi, A. Rabbi, K. Nasouri, A. M. Shoushtari, M. R. Babaei, Morphological and structural developments in nanoparticles polyurethane foam nanocomposite's synthesis and their effects on mechanical properties, Advances in Polymer Technology, 32(S1), E545-E555, (2012)

93 Ł. Piszczyk, M. Strankowski, M. Danowska, J. T. Haponiuk, M. Gazda, Preparation and characterization of rigid polyurethane-polyglycerol nanocomposite foams, European Polymer Journal, 48(10), 1726-1733, (2012)

${ }^{94} \mathrm{Z}$. Xu, X. Tang, A. Gu, Z. Fang, Novel preparation and mechanical properties of rigid polyurethane foam/organoclay nanocomposites, Journal of Applied Polymer Science, 106(1), 439-447, (2007)

95 J. Y. Lee, H. K. Lee, Characterization of organobentonite used for polymer nanocomposites, Materials Chemistry and Physics, 85(2), 410-415, (2004)

${ }^{96}$ D. García-López, I. Gobernado-Mitre, J. F. Fernández, J. C. Merino, J. M. Pastor, Influence of clay modification process in PA6-layered silicate nanocomposite properties, Polymer, 46(8), 2758-2765, (2005)

${ }^{97}$ K. Liang, ShQ. Shi, Nanoclay filled soy-based polyurethane foam, Journal of Applied Polymer Science, 119(3):1857-63, (2011) 
98 U.S. Environmental Protection Agency (www.epa.gov), Federal Register, Vol. 65, No. 243, Rules and Regulations, page 78980, December 18 , (2000)

99 M. Modesti, A. Lorenzetti, C. Dall'Acqua, New experimental method for determination of effective diffusion coefficient of blowing agents in polyurethane foams, Polymer Engineering \& Science, 44(12), 2229-2239, (2004)

100 J. Njuguna, S. Michałowski, K. Pielichowski, K. Kayvantash, A. C. Walton, Fabrication, characterization and low-velocity impact testing of hybrid sandwich composites with polyurethane/layered silicate foam cores, Polymer Composites, 32 (1), 6-13, (2011)

101 M. Danowska, Ł. Piszczyk, M. Strankowski, M. Gazda, J. T. Haponiuk, Rigid polyurethane foams modified with selected layered silicate nanofillers, Journal of Applied Polymer Science, 130(4), 2272-2281, (2013)

102 A. Lorenzetti, D. Hrelja, S. Besco, M. Roso, M. Modesti, Improvement of nanoclays dispersion through microwave processing in polyurethane rigid nanocomposite foams, Journal of Applied Polymer Science, 115(6), 3667-3674, (2010)

103 S. Pardo-Alonso, E. Solórzano, M. A. Rodriguez-Perez, Time-resolved x-ray imaging of nanofiller-polyurethane reactive foam systems, Colloids and Surfaces A: Physicochemical and Engineering Aspects, 438, 119-125, (2013)

${ }^{104}$ I. Rhoney, S. Brown, N. E. Hudson, R. A. Pethrick, Influence of processing method on the exfoliation process for organically modified clay systems. I. Polyurethanes, Journal of applied polymer science, 91(2), 1335-1343 (2004)

105 L. Madaleno, R. Pyrz, A. Crosky, L. R. Jensen, J. C. Rauhe, V. Dolomanova, J. Norman, Processing and characterization of polyurethane nanocomposite foam reinforced with montmorillonite-carbon nanotube hybrids, Composites Part A: Applied Science and Manufacturing, 44, 1-7, (2012)

${ }^{106}$ R. Gu, M. M. Sain, Effects of Wood Fiber and Microclay on the Performance of Soy Based Polyurethane Foams, Journal of Polymers and the Environment, 21(1), 30-38, (2013)

107 M. Zhu, S. Bandyopadhyay-Ghosh, M. Khazabi, H. Cai, C. Correa, M. Sain, Reinforcement of soy polyol-based rigid polyurethane foams by cellulose microfibers and nanoclays, Journal of Applied Polymer Science, 124(6), 4702-4710, (2012)

108 T. U. Patro, G. Harikrishnan, A. Misra, D. V. Khakhar, Formation and characterization of polyurethane-vermiculite clay nanocomposite foams, Polymer Engineering Science, 48(9), 1778-1784, (2008)

109 P. Mondal, D. V. Khakhar, Rigid polyurethane-clay nanocomposite foams: Preparation and properties, Journal of Applied Polymer Science, 103(5), 2802-2809, (2007).

110 P. C. Ma, N. A. Siddiqui, G. Marom, J. K. Kim, Dispersion and functionalization of carbon nanotubes for polymer-based nanocomposites: A review, Composites Part A: Applied Science and Manufacturing, 41(10), 1345-1367, (2010)

${ }^{111}$ M.A. Rodríguez-Pérez, J. I. González-Peña, N. Witten, J.A. de Saja, The effect of cell size on the physical properties of crosslinked closed cell polyethylene foams produced by a high pressure nitrogen solution process, Cellular polymers, 21(3), 165-194. (2002) 
Chapter 2: Background and State of the Art

112 S. H. Kim, M. C. Lee, H. D. Kim, H. C. Park, H. M. Jeong, K. S. Yoon, B. K. Kim, Nanoclay reinforced rigid polyurethane foams, Journal of Applied Polymer Science, 117(4), 1992-1997, (2010) 

CHAPIER 3:

\section{MATERIALS AND CHARAC TERISATION TECHNIQUES}





\section{MATERIALS AND CHARACTERISATION TECHNIQUES}

This chapter summarizes the selected materials for this thesis, the facilities employed for the production and characterisation of the foams and the specific methodologies used for producing and characterising the materials.

\subsection{Materials}

\subsubsection{Polyurethane}

Three different formulations of rigid polyurethane foam supplied by the industrial partners BASF ( 1 formulation) and Recticel ( 2 formulations) were employed in this thesis. The selection of these materials was conditioned by the NanCore project (see introduction chapter, point 1.1: Motivations). The aim of this project was developing a microcellular nanocomposite for substitution of Balsa wood and PVC core material. Because of this, the selection was restricted to low densities and good initial mechanical properties (i.e. stiffness and strength) for a given density.

TABLE 3.1. Main characteristic of the different polyurethane formulations employed in this research

\begin{tabular}{|c|c|c|c|c|c|c|}
\hline & Commercial name & $\begin{array}{l}\text { Normal } \\
\text { density in } \\
\text { free foaming } \\
\left(\mathrm{Kg} / \mathrm{m}^{3}\right)\end{array}$ & $\begin{array}{l}\text { Pol./ Iso. } \\
\text { ratio (in } \\
\text { weigth) }\end{array}$ & $\begin{array}{l}\text { Polyol } \\
\text { viscosity } \\
\text { (mPA.s) }\end{array}$ & $\begin{array}{l}\text { Type of } \\
\text { polyol }\end{array}$ & $\begin{array}{c}\text { Isocyanate } \\
\text { type }\end{array}$ \\
\hline BASF (LV) & $\begin{array}{l}\text { Polyol: Elastopor* H } \\
1501 / 2 \\
\text { Isocyanate: IsoPMDI } \\
92140\end{array}$ & 52 & $100 / 160$ & 650 & $\begin{array}{l}\text { Poly- } \\
\text { ether } \\
\text { polyol }\end{array}$ & MDI \\
\hline $\begin{array}{l}\text { Recticel low } \\
\text { viscosity } \\
\text { (MV) }\end{array}$ & - & 120 & $100 / 74$ & 1000 & - & MDI \\
\hline $\begin{array}{l}\text { Recticel high } \\
\text { viscosity } \\
\text { (HV) }\end{array}$ & - & 50 & 100/196 & 100000 & - & MDI \\
\hline
\end{tabular}

BASF formulation was a commercial formulation, however Recticel formulations were specifically designed for the project, as the company Recticel was a partner of NanCore. Nominal density of BASF product is $52 \mathrm{Kg} / \mathrm{m}^{3}$, whereas Recticel materials have densities of 50 
and $120 \mathrm{Kg} / \mathrm{m}^{3}$. One important aspect taken into account in the selection of the formulations was the polyol viscosity. Three different levels were selected.

All the employed blends were methylene diphenyl diisocyanate type (MDI) and the foam was produced using water as blowing agent. Some of the main features of the different formulations are shown in table 3.1, where the short name (related with the formulation viscosity) that will be employed in the following sections is indicated. As it is shown in this table the viscosity of the polyol of the different formulations varies from 650 to 100.000 mPA.s, a wide range of values that will enable to observe a variety of behaviours as a function of the dispersion technique employed.

\subsubsection{Nanoclays}

Cloisite 30b nanoclays were selected for this research. This is a natural montmorillonite modified with a quaternary ammonium salt, purchased from Southern Clay Products. These nanoclays are conventionally employed to improve various physical properties of polymers, such as stiffness, strength, heat distortion temperature, linear thermal expansion coefficient and barrier properties. Table 3.2 shows the main characteristics of this product measured by the manufacturer.

TABLE 3.2. Main characteristics supplied by the material producer.

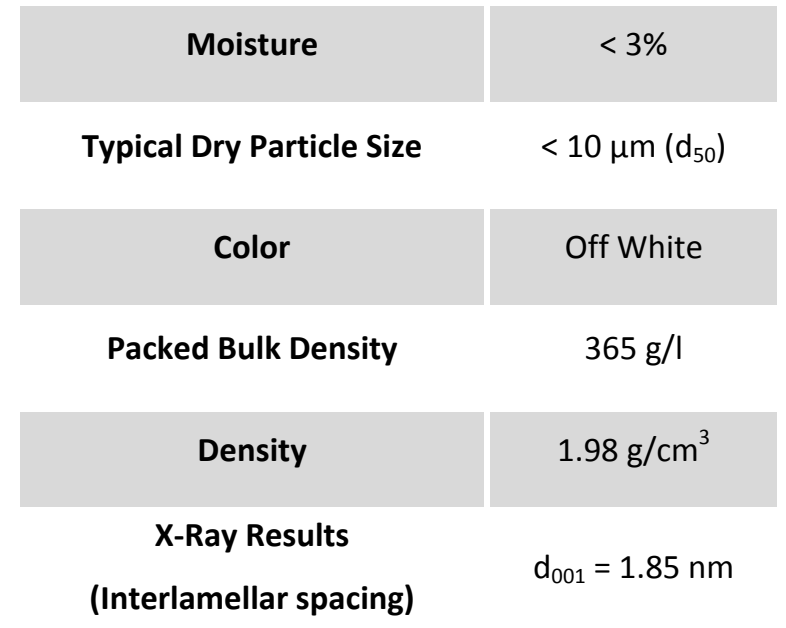

Two reason were taken into account in the selection of this type of clays: the manufacturer recommendations and, as it has been shown in the state of the art section (section 2.4), their use in previous articles on polyurethane foams infused with nanoclays. In the mentioned section, it is 
possible to observe how this type of nanoclays has produced an improvement in some characteristics of polyurethane foams, such as cellular structure or thermal conductivity.

\subsubsection{Foams production}

Reactive foaming was used to produce the foams. This technique consists in the mixing of the two reactive products that generate the final polyurethane foam. Some important details were learned during this stage of the work:

- Pre-mixing of the polyol component is highly recommended: as polyol usually includes a variety of components (see Background and state of the art section, 2.2.1. Chemistry of the polyurethane section) with different densities, a reduction of homogeneity can be produced over time. Usually, 90 second of premixing at 1200 rpm is enough to recover homogeneity of polyol, but this depends on the viscosity of polyol and on the possible formation of separated solid phases at the bottom of the cups used for mixing.

- Reactives temperature: As the chemical reactions produced during polyurethane polymerization/foaming are highly dependent on the temperature, it is also highly recommended to use the polyol and the isocyanate at a constant temperature in order to improve the reproducibility in the foams production. Otherwise, different room temperature can produce changes in the structure and properties of produced foams.

- Polyol-isocyanate mixing tools: IKA Eurostar Power control-visc P1 (Fig. 3.1.a), and Lenart Disc (Fig. 3.1.b) were selected due to the recommendation of different groups which had previously worked in polyurethane foams field. The use of the Lenart Disc must be matched to the use of a plastic, cylindrical shaped container to proceed to polyol-isocyanate mixing: thereby a more active mixing of both components is produced.

- Mixing tools must be cleaned completely immediately after foam production, other way after the polymerization of the polyurethane it is much harder to clean the tools. Acetone was employed for this purpose, submerging the mixing tools under it for around 30 seconds. 


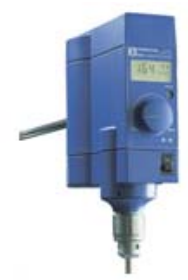

(a)

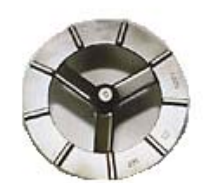

(b)

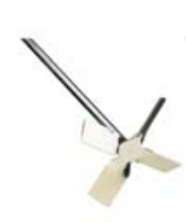

(c)

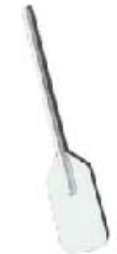

(d)

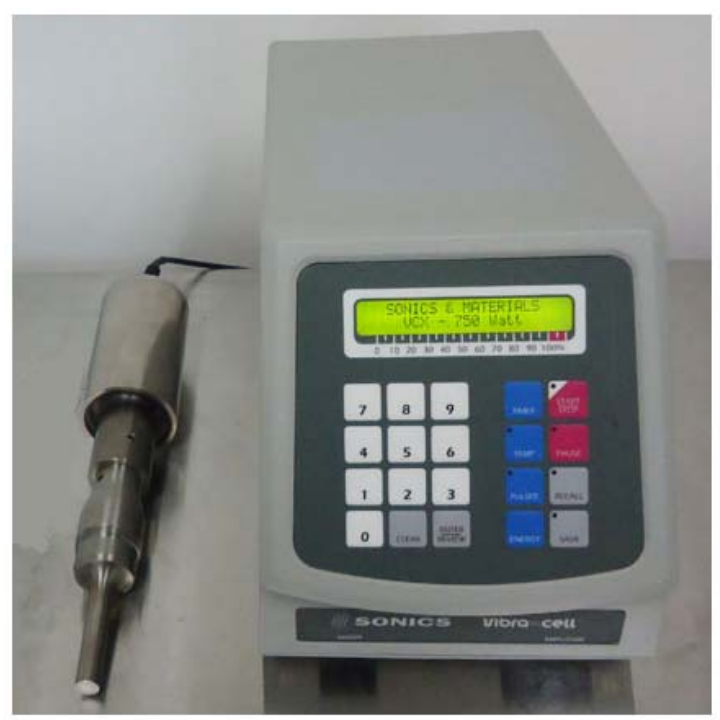

(e)

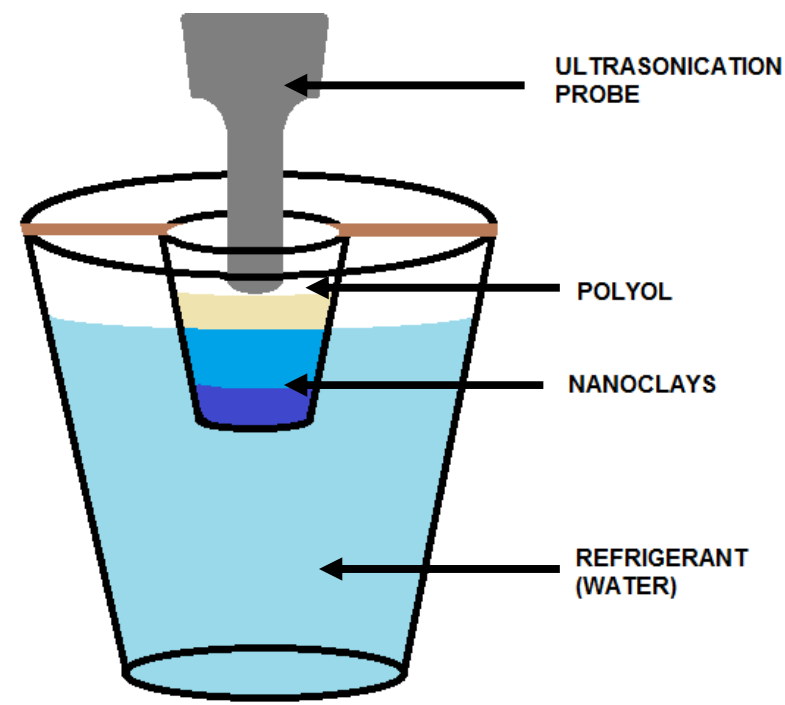

(f)

FIGURE 3.1 (a) IKA Eurostar Power control-visc P1; (b) Lenart Disc (c) x-shapped blade; (d) mixing spoon; (e) Ultrasonication module and ultrasonication probe; (f) experimental set-up for ultraonication scheme 
For the production of foams using BASF formulation, polyol and isocyanate were mixed at 1200 rpm for 15 seconds in a plastic container. Immediately afterwards this mixture was transferred to a paper mould in which the reaction and the foaming process was completed.

For the production of nanoclays infused polyurethane foams, an extra step is required previous to isocyanate-polyol mixing: the nanoclays dispersion into one of these reagents. This step has supposed the learning of some details:

- Dispersion of nanoclays must be done in the polyol: high reactivity of isocyanate justifies this selection, as isocyanate is very reactive toward active hydrogen containing compounds. Thereby, nanoparticles were dispersed in polyol component to avoid possible secondary reactions between fillers and the dispersing medium during the nanoclays dispersion. This is a critical point for ultrasonication, as an increase of temperature in the components is produced during the use of this technique.

- Nanoclays must be dehydrated previous to their dispersion: in order to avoid any moisture, nanoclays were dehydrated overnight in a vacuum oven. Similar treatment was observed in related literature. The motivation of this procedure is the high reactivity of isocyanate with water, described in the background section. Some previous tests showed a decrease in density of foams when in non-dehydrated nanoclays were used: the presence of water in this component should act as foaming agent.

- No compensation of the amount of isocyanate was required: although the funcionalization of the nanoclays introduces an extra amount of hydroxyl groups (very reactive with isocyanate, see background section), it is not required an increase in the amount of isocyanate included. Some tests were performed to confirm this. The use of an extra amount of isocyanate only produced an increase of the foam density with respect to the material with a standard isocyanate amount, without any considerable change in any of the mechanical or structural properties.

The main characteristics (mixing tool, mixing time and mixing speed) of the dispersion techniques employed to introduce the nanoparticles are shown in Table 3.3. As it has been commented, the dispersion was always performed in polyol. Other characteristics of these techniques are showed below:

- Hand mixing technique has the lower dispersion quality potential and was employed due to the high sensitivity of the BASF polyol to the dispersion technique employed. For 
this purpose, a spoon (Fig. 3.1.(d)) was employed with the objective to obtain at least an apparent good dispersion, trying to eliminate any kind of solid residues in the polyolnanoclays mixture.

TABLE 3.3. Main characteristics of the dispersion techniques employed.

\begin{tabular}{|c|c|c|c|c|}
\hline Dispersión technique & Mixing tool & $\begin{array}{l}\text { Mixing time } \\
\text { (s) }\end{array}$ & $\begin{array}{l}\text { Mixing speed } \\
\quad(\mathrm{rpm})\end{array}$ & Other characteristics \\
\hline Hand Mixing (HM) & Spoon (Fig. 3.1.d) & $\sim 30$ & 30 & - \\
\hline Low shear mixing (LS) & $\begin{array}{l}\text { IKA Eurostar Power } \\
\text { control-visc P1, } \\
\text { equipped with a 4- } \\
\text { bladed propeller stirrer } \\
\text { (Fig. 3.1.c) }\end{array}$ & 120 & 200 & - \\
\hline Ultra-sonication (US) & $\begin{array}{l}\text { Sonics Vibra-Cell VCX } \\
750 \text { (Fig. 3.1.e), } 20 \mathrm{KHz} \text {, } \\
\text { cycles of } 3 \text { seconds of } \\
\text { sonication, } 2 \text { seconds } \\
\text { between cylce }\end{array}$ & 1500 & - & $\begin{array}{l}\text { Hand premixing of } \\
\text { nanoclays in the } \\
\text { polyol component for } \\
\text { a better } \\
\text { ultrasonication }\end{array}$ \\
\hline
\end{tabular}

- Low shear mixing employs an x-shape mixing head (Fig. 3.1.c) that is rotated at low speed $(200 \mathrm{rpm})$ for 120 seconds. A macroscopic good distribution and dispersion of the nanoclays in the polyol was produced (from visual examination), obtaining a polyolnanoclays mixture where it was not possible to appreciate rest of isolated, macroscopic nanoclays clusters.

- Ultrasonication was performed with Sonics Vibra-Cell VCX 750 (Fig. 3.1.a), composed by two parts: the ultrasounds generator and the tip horn. This technique is based in the production of high frequency vibrations $(20 \mathrm{KHz})$ that interact with the nanoclays agglomerates producing their separation. In order to optimize the ultrasonication technique, hand premixing of nanoclays in all polyol volume was performed prior to ultrasonication. Due to the high energy transferred from the ultrasonication tip to the polyol-nanoclays mixture, this technique produces an increase of the temperature. This increase can affect polyol and its additives, in particular catalyst and foaming agent; 
therefore a good control of the temperature is required. For this reason, a water bath at a temperature of $25^{\circ} \mathrm{C}$ was employed during ultrasonication, avoiding the overheating of the polyol-nanoclays mixture (Fig. 3.1.e). Furthermore, different test showed that cycles of 3 second of ultrasonication with 2 seconds between cycles was the best way to obtain an appropriate dispersion, avoiding at the same time polyol overheating.

To produce the nanoclays infused polyurethane foams, the next steps were carried out (Fig. 3.2):

1. The exact amount of nanoclays for a given concentration in the final foam was weighted in a plastic container. Then the exact amount of polyol was added.

2. Then nanoclays were dispersed in the polyol, using one of the different dispersion techniques previously mentioned (table 3), trying to obtain an optimal apparent dispersion.

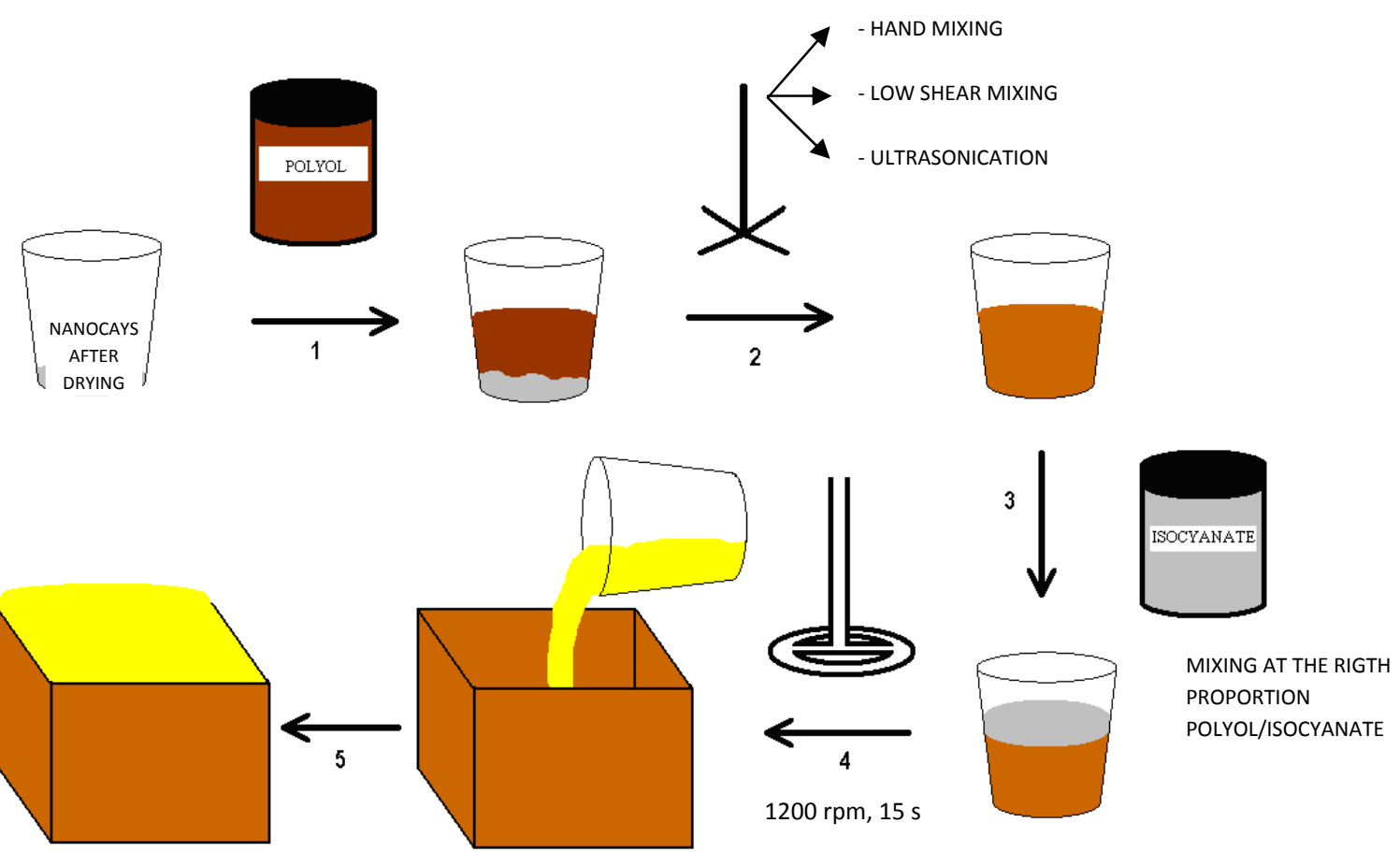

FIGURE 3.2 Foams manufacture scheme

3. After that, the precise amount of isocyanate was added, in order to have a ratio of 100:160 between polyol and isocyanate (BASF polyurethane, see table 1) 
4. Components were mixed at $1200 \mathrm{rpm}$ for 15 seconds with an IKA Eurostar mixer, equipped with a Lenart Disc (Fig. 3.1.b).

5. The mixed liquids were poured for foaming into a paper mould with dimensions $110 \times 110 \times 80 \mathrm{~mm}^{3}$ in the case of samples for the dispersion quality study, and $310 \times 250 \times 60 \mathrm{~mm}^{3}$ in the case of samples for the different nanoclays concentrations study. Different mould sizes was selected taking into account the final dimensions needed for testing. For other polyurethane formulations (Table 3.1) the same procedure was used modifying the polyol/isocyanate ratio following the indications of table 3.1.

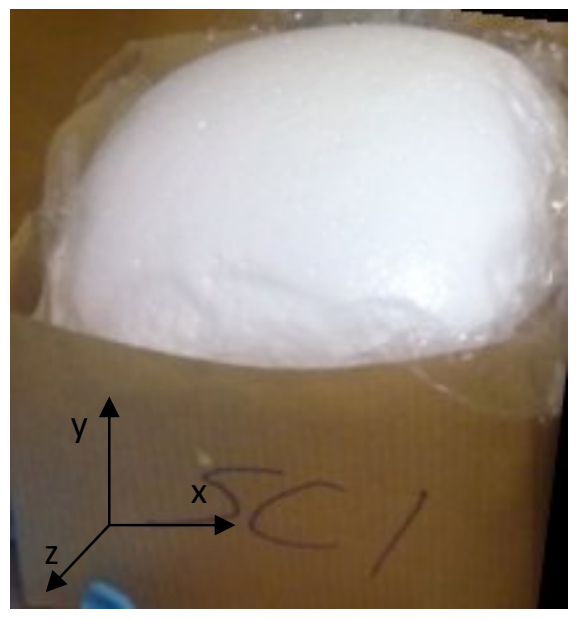

FIGURE 3.3 Final foam sample and the axis orientation considered in the present work (y direction corresponds to the growing direction)

\subsubsection{Samples preparation}

After the foaming and curing process (at least 48 hours at room temperature), samples were cut from the main blocks to proper characterize them, removing any remaining skin in a first. The cutting process is described in Fig. 3.4 and Fig. 3.5 (for both moulds sizes employed, see previous section) and two different steps are represented. On Fig. 3.4.b it is shown the first cut for the first type of mould, zone number 1 (a parallelepiped with a $5 \times 5 \mathrm{~cm}^{2}$ basis) was cut on further step (Fig3.4.C, a variable amount of material was removed in the vertical direction in order to obtain a perfect cube of $5 \times 5 \times 5 \mathrm{~cm}^{3}$ ) for mechanical compression study. Zones $2,3,4$ and 5 , with a variable thickness depending on the amount of material eliminated in the moment of removing the skin, were employed for the different characterization experiments. 


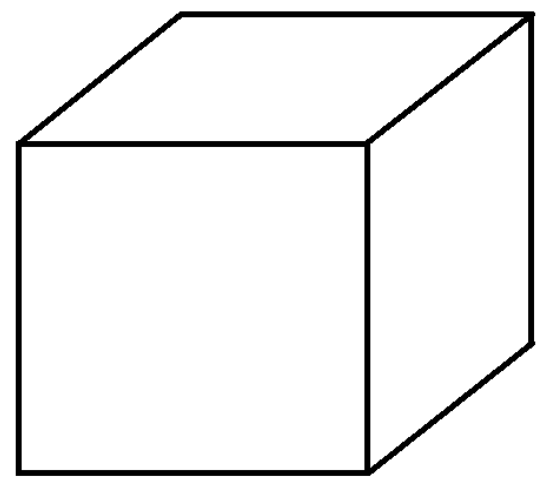

(a)

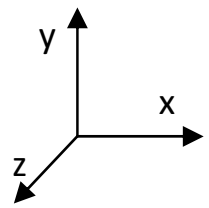

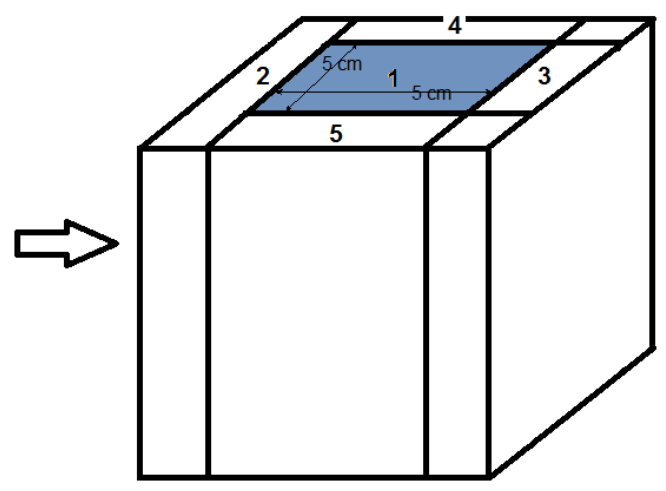

(b)

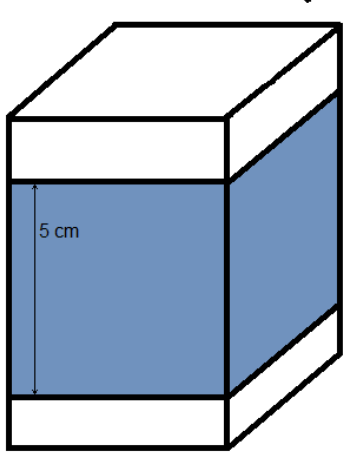

FIGURE 3.4. Cutting scheme for dispersion techniques study ( $y$ is the foaming direction): (a) Initial foam (b) First cut (c) Second cut.

(a)
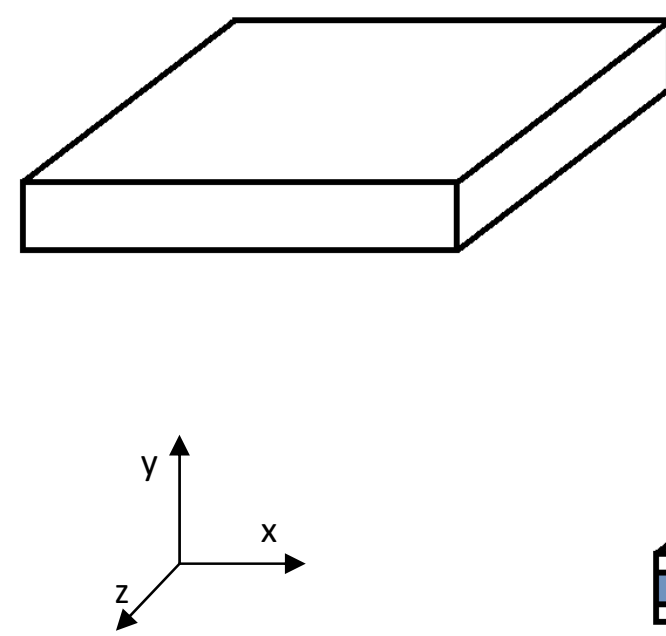

(b)

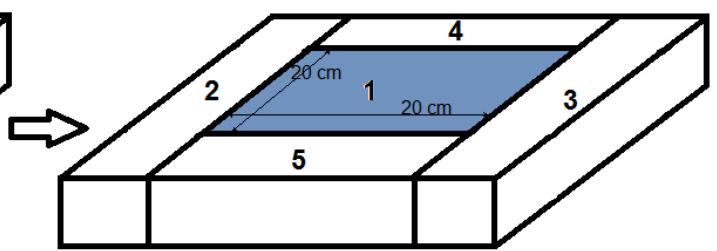

(c)

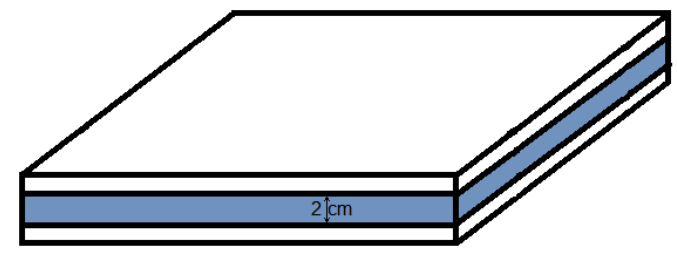

FIGURE 3.5. Cutting scheme for nanoclays concentrations study ( $y$ is the foaming direction): (a) Initial foam (b) First cut (c) Second cut.

Fig. 3.5.b shows the first cut for the second type of mould, specific for thermal properties measurements. Zone number 1 (a parallelepiped with a $20 \times 20 \mathrm{~cm}^{2}$ basis) was cut on 
further step (Fig3.5.c, a variable amount of material was removed in the vertical direction in order to obtain a parallelepiped of $20 \times 20 \times 2 \mathrm{~cm}^{3}$ ) for thermal conductivity study. Zones $2,3,4$ and 5, with variable dimensions, were employed for the different characterization experiments. Previous to this characterization any remaining skin was removed.

\subsection{Macroscopic Techniques}

\subsubsection{Rheology}

Rheology has been used previously as a complementary technique to probe the state of dispersion, at least in a qualitative way ${ }^{1-4}$. Recently, rheological methods have been extended to be used in a more quantitative way $y^{5,6}$. In the present work, rheological measurements were performed on the polyol-nanoclays mixtures with the aim of characterising dispersion quality, trying to clarify the effect of the different dispersion techniques over different types of polyol. Sample preparation protocol was as follows: nanoclays were dehydrated over night with the objective to eliminate any moisture, then the precise amount of polyol was added and finally a different dispersion process was carried out, as it is indicated in table 3.3.

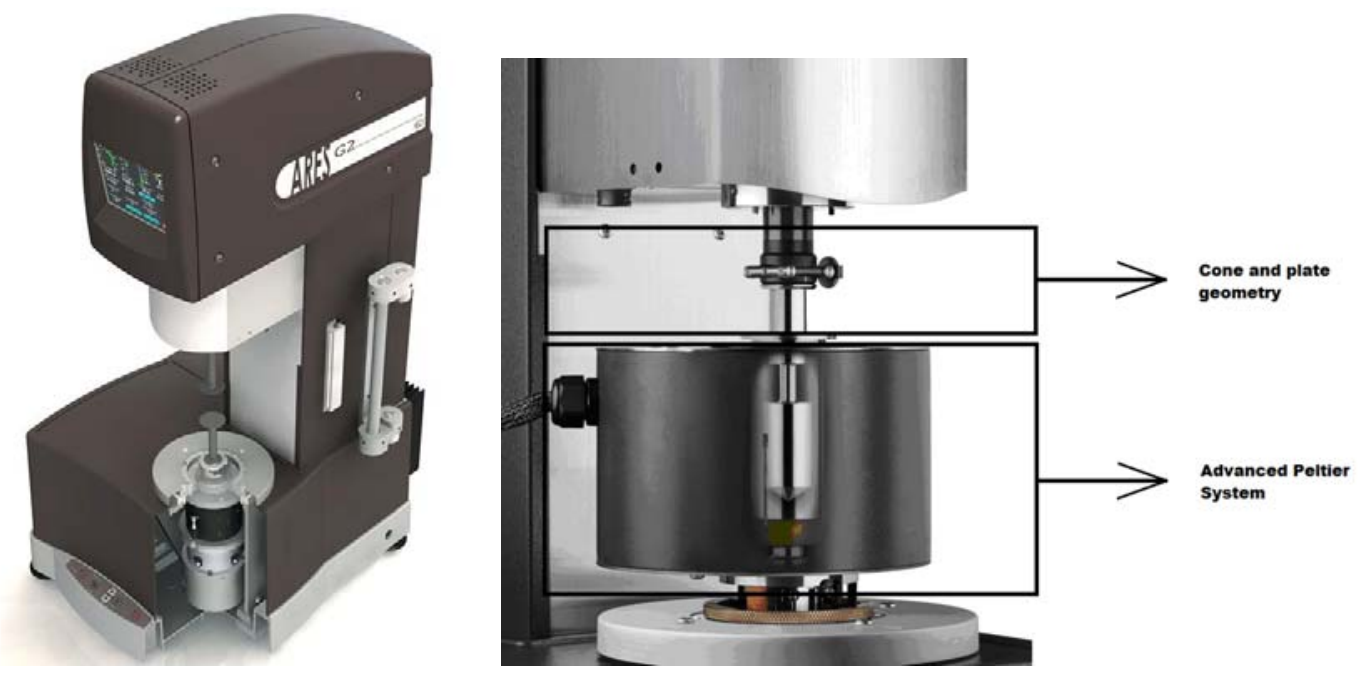

FIGURE 3.6 Rheology facilities: a) Ares G2; b) APS

These experiments were carried out on a strain-controlled rheometer (Fig. 3.6.a, ARES$\mathrm{G} 2$, TA Instruments) equipped with a cone and plate geometry (diameter $50 \mathrm{~mm}$, angle 0.02 rad). Temperature was controlled with an APS (Advanced Peltier System, Fig. 3.6.b) and maintained at $23^{\circ} \mathrm{C}$. To avoid effects of loading and sample history, a fixed preshear protocol was adopted. This protocol consists of continuously shearing at $1 \mathrm{~s}^{-1}$ for 5 minutes and an equilibration of $1500 \mathrm{~s}$, after which the rheological test was performed. No significant increase 
in the dynamic moduli was seen after this equilibration period. Dispersion quality was analysed by applying small sinusoidal shear strains to the sample in the linear viscoelastic regime. In this regime, a fingerprint of the microstructure of the sample is obtained by slightly perturbing the microstructure without disturbing it. A sinusoidal strain $\varepsilon$ with angular frequency will results in a sinusoidal shear stress $\boldsymbol{\sigma}$ with the same frequency, but with a different phase lag $\boldsymbol{\delta}$ (Fig. 3.7).

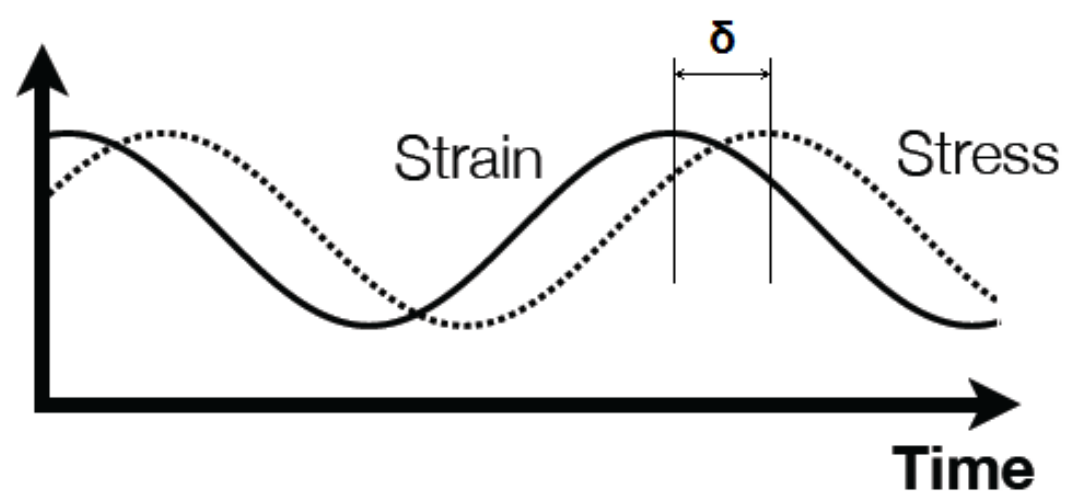

FIGURE 3.7.- Relationship between strain $(g)$, stress $(s)$ and time

The constant of proportionality is the complex shear modulus $G^{*}$ (Eq. 1 and 2).

$$
\begin{gathered}
\sigma=G^{*} \cdot \varepsilon \\
G^{*}=G^{\prime}+i G^{\prime \prime}
\end{gathered}
$$

The storage or elastic modulus $G^{\prime}$ represents the in-phase part of the stress and describes the solid-like response of the material, the storage of elastic energy. The loss or viscous modulus $G$ " represents the out-phase part of the stress and characterizes the liquid-like behaviour of the material, the viscous dissipation.

Similarly, the complex viscosity $\eta^{*}$ (Eq. 3 ) is defined as the constant of proportionality between the shear stress $s$ and the shear rate $\dot{g}$ (Eq. 4). In this representation, $\eta^{\prime}$ represents the viscous response and $\eta^{\prime \prime}$ represents the elastic response.

$$
\begin{gathered}
\eta^{*}=\eta^{\prime}+i \eta^{\prime \prime} \\
\sigma=\eta^{*} \dot{\varepsilon}
\end{gathered}
$$

The frequency dependent moduli were measured between 0.01 and $100 \mathrm{rad} \mathrm{s}^{-1}$ in the linear regime where the moduli are independent of the strain amplitude $g_{0}$. Both particle concentration and dispersion quality of the particles are known to affect the dynamic moduli $\mathrm{G}^{\prime}$ and $\mathrm{G}^{\prime \prime}$ as a function of frequency. The linear viscoelastic properties of nanoclay-polyol 
dispersions can be employed to determine the response of a formulation to the dispersion protocol.

Plateu at low frequencies
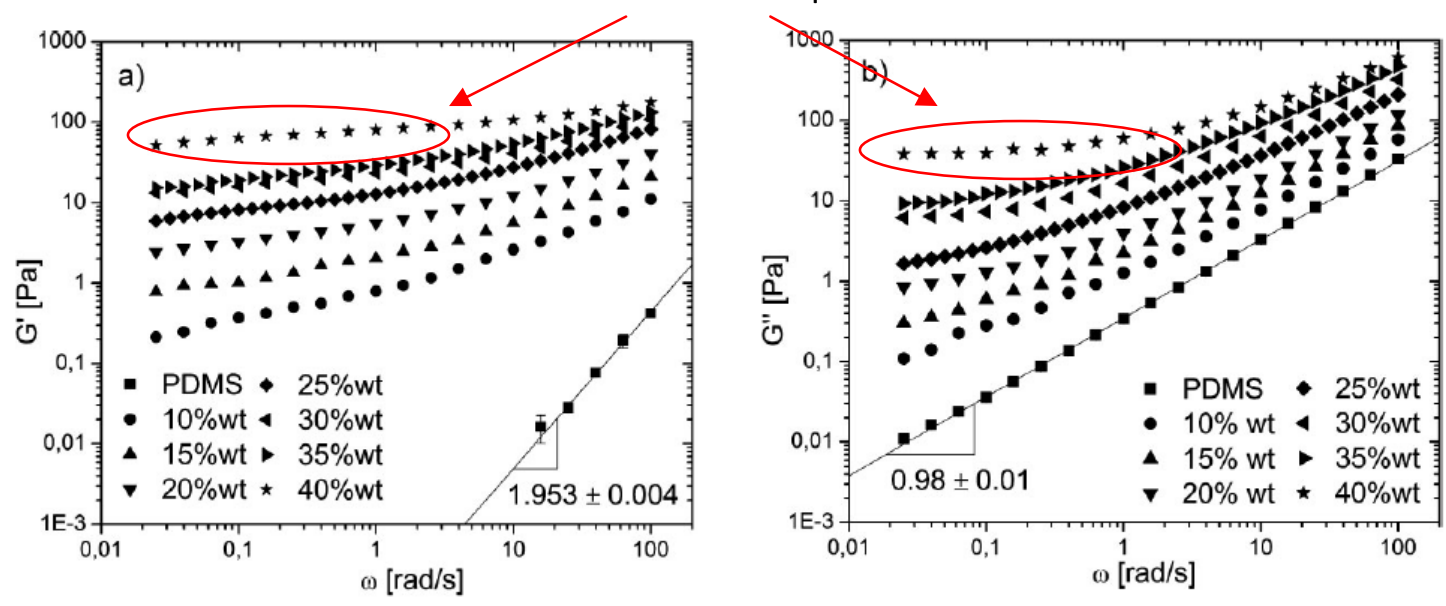

FIGURE 3.8 Linear viscoelastic properties as a function of frequency for a PMDS matrix filled with different amounts of silica nanoparticles ${ }^{\text {iError! Marcador no definido. }}$. (a) Storage moduli (b) Loss moduli

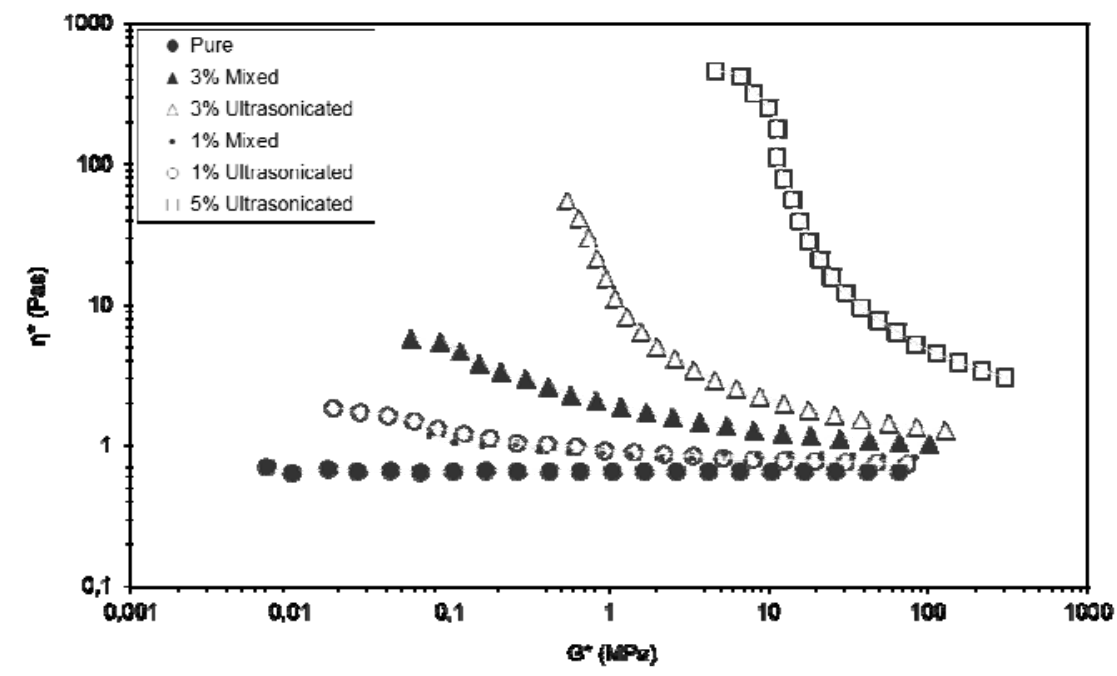

FIGURE 3.9.- Winter Plot for different concentrations and dispersion techniques. The quality of the dispersion can be related with the change in the slope, for a fixed concentration.

The effect of particle concentration and dispersion quality can be interpreted as an increase in the effective volume fraction of the particles in the polymer matrix as particle (weight) concentration and dispersion quality rises. As the effective volume fraction of the particles increases, either by the addition of particles or by either at fixed concentration increasing the dispersion quality, a percolating network can be formed, indicated by a plateau in the low frequent moduli, characteristic for solid like materials. At high frequencies, the 
matrix contribution dominates the response in the loss modulus $G^{\prime \prime}$. The particles deform the interstitial matrix leading to increase dissipation. The high frequency dependent response of $G^{\prime \prime}$ of the dispersions becomes parallel to the response of the matrix material. Both low frequency as well as high frequency moduli can be used to quantify dispersion quality ${ }^{5,6}$. Fig.3.8 shows these changes in the rheological behaviour for silanized silica nanoparticles $\left(\mathrm{SiO}_{2}\right)$ dispersed in a polydimethylsiloxane matrix (PDMS)

To determine which material is the most sensitive to changes in the preparation procedure, the so-called Winter-plot can be used ${ }^{7,8}$, which allows a rapid and straightforward comparison between different materials at a fixed concentration. In this plot, the modulus of the complex viscosity $\left|\mathbf{h}^{*}\right|$ is plotted versus the modulus of the complex shear modulus $\left|\mathbf{G}^{*}\right|$ (See Fig. 3.9). Winter, $2009^{7}$ showed, by the rearrangement of the Cox-Merz rule, the equivalency of complex modulus in oscillatory experiments and the shear stress in steady shear flow, which is very sensitive parameter to the material microstructure ${ }^{5}$. For a material with a solid-like behaviour (liquid with well dispersed particles) at low frequencies, the complex viscosity will shoot up with decreasing complex modulus, which is in a normal viscosity-shear stress plot a clear indication of a yield stress ${ }^{5}$. This can be easily observed for different concentrations and dispersion techniques in Fig. 3.9: for a fixed concentration a greater change in the slope is observed for most powerful dispersion technique (ultrasonication against mixing).

\subsubsection{Density}

Previous to density measurements, foamed samples were conditioned at $21 \pm 2{ }^{\circ} \mathrm{C}$ and $50 \%$ relative humidity for at least $48 \mathrm{~h}$. Density measurements were performed in accordance with ASTM D $1622^{9}$, as the quotient between mass and volume. Cubic samples were produced in order to have a regular size which allowed an easy way to measure the volume. Samples dimensions were measured with the help of a gauge tool, and samples mass was measured in a precision balance model AT261 from Mettler Toledo (Fig. 3.10). 


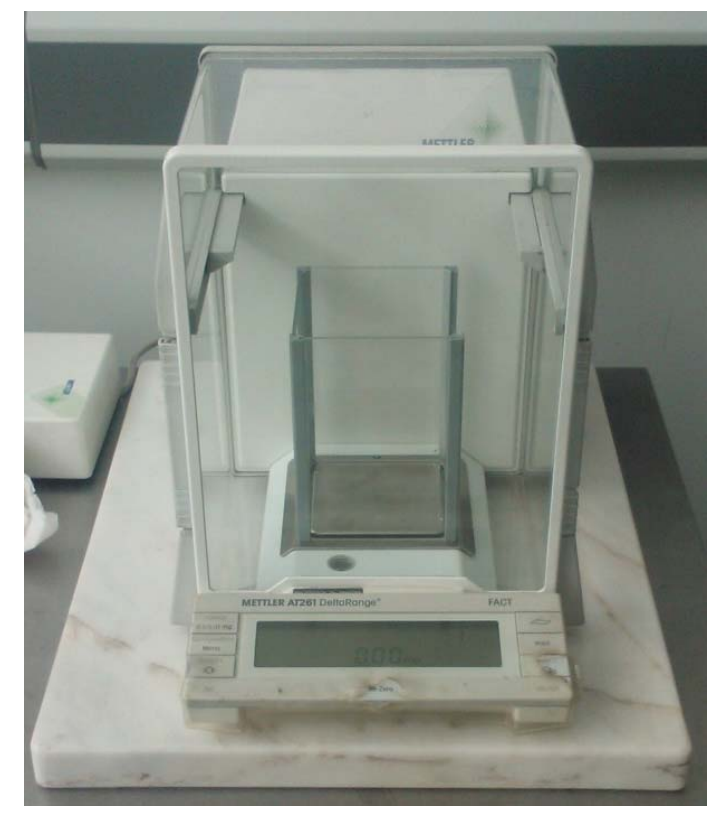

FIGURE 3.10. Precision balance model AT261 from Mettler Toledo

\subsubsection{Mechanical properties at low strain rates: compression, bending and torsion tests.}

Compression and bending experiments at low strain rates and shear modulus measurements were performed to characterize the mechanical behaviour (stiffness and strength). Previous to mechanical characterisation, foamed samples were conditioned at $21 \pm 2$ ${ }^{\circ} \mathrm{C}$ and $50 \%$ relative humidity for at least $48 \mathrm{~h}$.

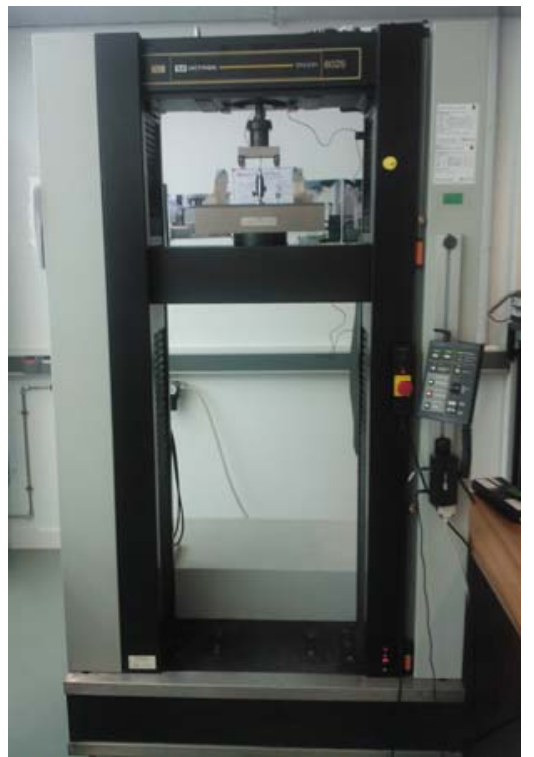

(a)

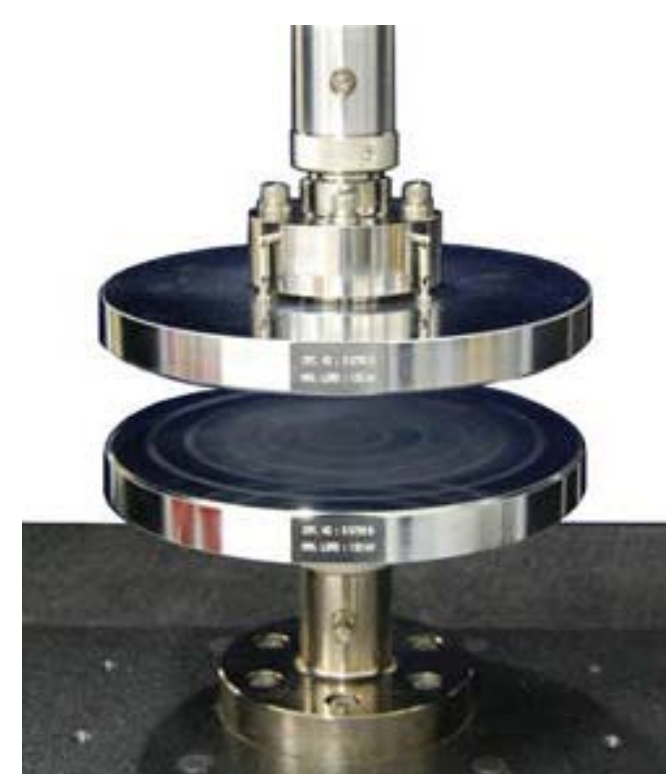

(b)

FIGURE 3.11.- (a) Universal testing machine model 5500R6025 from Instrom; (b) Parallel plates system employed for compression test 
For compression experiments, the stress $(\sigma)$ strain $(\varepsilon)$ curves were measured with an Instron machine (model 5500R6025, Fig. 3.11.a) at room temperature and at a deformation rate of $10 \% \mathrm{~min}^{-1}$, according to ASTM D1621 ${ }^{10}$, with a parallel plates system (Fig. 3.11.b). Stress was applied in the foaming direction ( $y$ direction in Fig 3.3). The maximum static strain was approximately $75 \%$ for all the experiments. Dimension of the samples was $50 \times 50 \times 50 \mathrm{~mm}^{3}$. Two mechanical properties were obtained from these experiments, elastic modulus and collapse strength.

A typical strain-stress curve is shown in Fig. 3.12. The part of the curve before A point is produced by small imperfections in the sample shape, that originate this behaviour prior to a full contact between sample faces and universal testing machine plates. The slope of the initial zone of the stress strain curve gives the elastic modulus (between A and B points). Collapse strength was measured as the maximum of the curve (point $\mathrm{C}$ ). No extensometers were employed for these measurements.

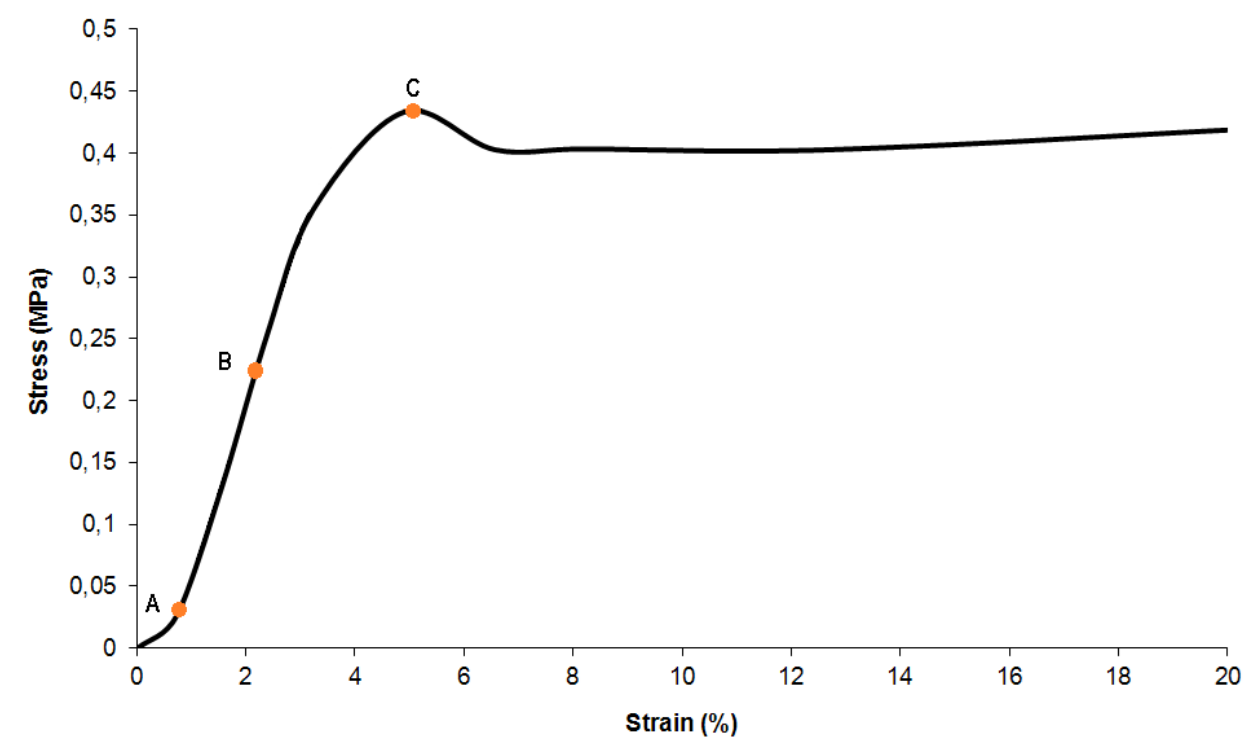

FIGURE 3.12. Typical strain-stress compression curve for a polyurethane foam with density of 50

$$
\mathrm{kg} / \mathrm{m}^{3}
$$

The flexural properties were measured using an Instron universal testing machine (model 5500R6025, Fig. 3.11 (a)) under the three-point loading scheme (Fig. 3.13), in accordance with ISO 178:2010 ${ }^{11}$. Stress was applied in the foaming direction ( $y$ direction in Fig 3.3). Sample size was $120 \times 15 \times 15 \mathrm{~mm}^{3}$. Stress $(\sigma)$ strain $(\varepsilon)$ curves were measured at $21 \pm 2{ }^{\circ} \mathrm{C}$ and $50 \%$ relative humidity and at a deformation rate of $10 \mathrm{~mm} / \mathrm{min}$. Flexural modulus, flexural strength and deformation at maximum strength (\%) were obtained from these experiments. 


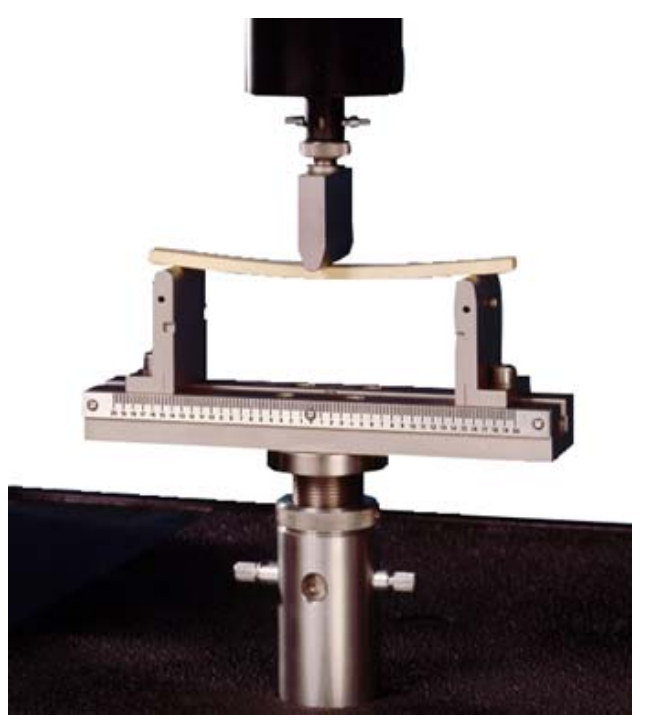

FIGURE 3.13. Three-point loading scheme apparatus

A typical strain-stress curve for the three point loading scheme is shown in Fig. 3.14. The slope of the initial zone of the stress strain curve is proportional to the flexural modulus (between $A$ and $B$ points). Deformation at maximum strength $\left(\varepsilon_{\mathrm{MS}}\right)$ was measured as the deformation of the sample at the maximum strength (point $\mathrm{C}$ ), just before the break of the sample. Flexural strength $\left(\sigma_{\mathrm{MS}}\right)$ was measured as the maximum flexural stress detected during the experiment. No extensometers were employed for these measurements.

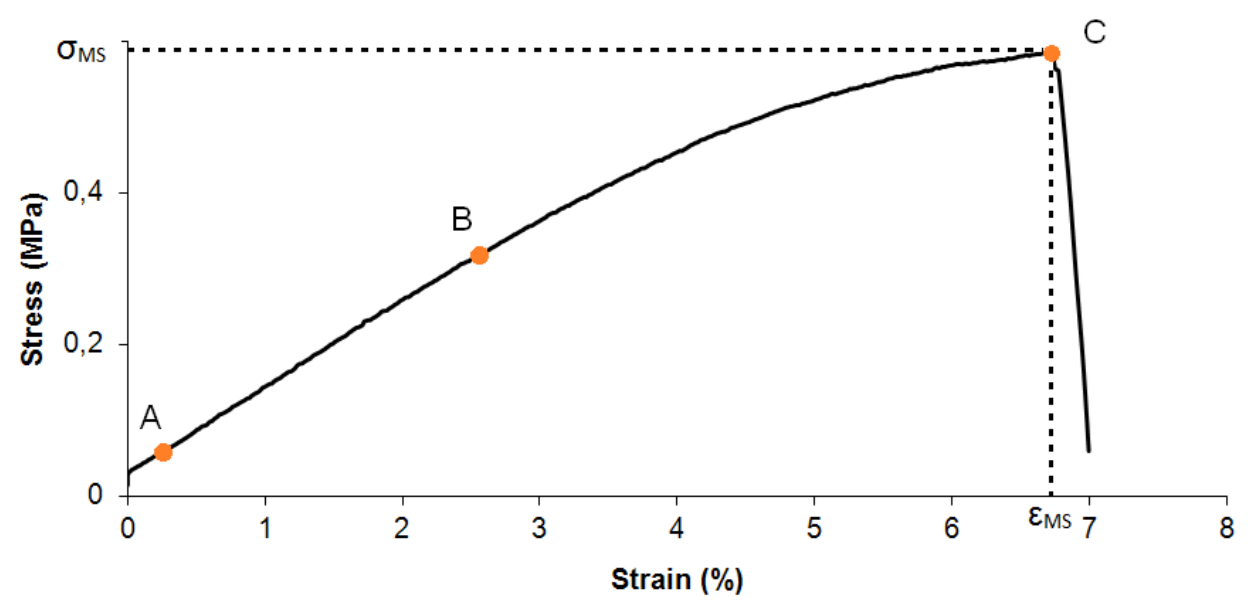

FIGURE 3.14. Typical strain-stress flexural curve for a polyurethane foam with a density of $50 \mathrm{~kg} / \mathrm{m}^{3}$

Shear modulus measurements were performed by the Katholieke Universiteit Leuven (KUL) in Belgium. Both foaming direction ( $y$ ) and neutral direction $(x)$ were considered (as they were defined in Fig. 3.3), in order to observe possible effects of the cellular anisotropy on the shear modulus, as can be seen in Fig. 3.15 (a). 


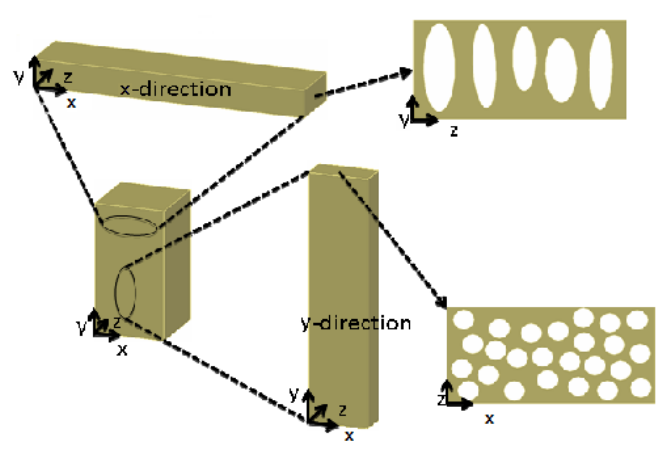

(a)

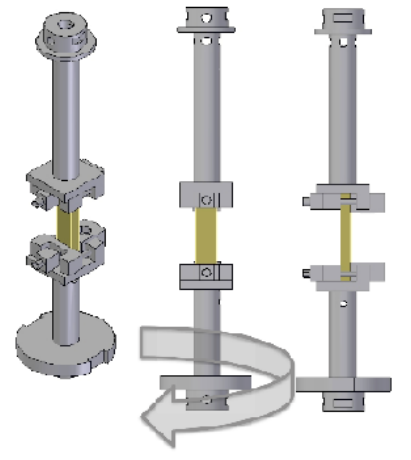

(b)

FIGURE 3.15.- (a) Direction of the different cuts and cell anisotropy on them. (b) Support employed for the measurements.

To perform these measurements, a torsion rectangular geometry was employed on Ares-melts rheometer (TA-instrument, Fig. 3.15 (b)). Rectangular foam bars of $45 \times 10 \times 5 \mathrm{~mm}^{3}$ were clamped to a specific torque between two anvils with a torque screw driver (see Fig. 3.15 (b)). The sample is held in tension between the upper and lower tool. Sample dimensions are measured with an accuracy of $0.01 \mathrm{~mm}$ with a vernier caliper.

$$
T=\frac{J_{T}}{l} G \cdot \theta
$$

Shear modulus (G) emerge from generalized Hooke's law, and gives the relationship between the torsion applied $(T)$ and the deformation angle $(\theta)$, as it is shown in Eq. 5 . Other elements on this equation are $J_{T}$ which is the torsion constant of the section (depends on the sample geometry and was calculated as it is shown in Fig. 3.16), and / which is the length of the object that is being studied.

\section{Solid Rectangular Section}

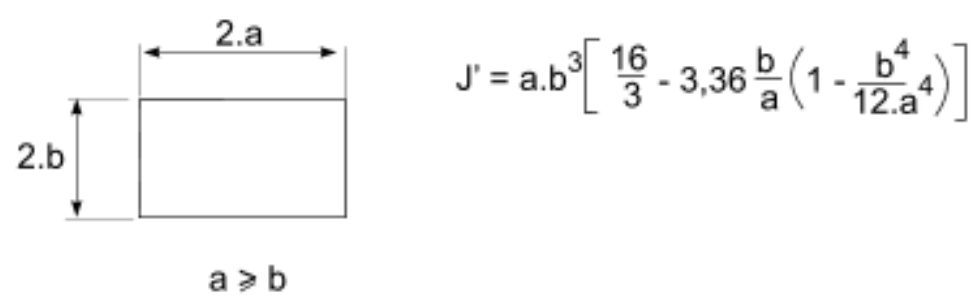

FIGURE 3.16.- Torsion constant for a solid rectangular section 


\subsubsection{Dynamic Mechanical Analysis (DMA)}

Dynamic mechanical analysis (DMA) is employed to measure the viscoelastic properties of materials as a function of temperature, time and frequency when they are subjected to a periodic stress. The types of materials that can be analyzed with this technique include thermoplastics, thermosets, composites, elastomers, ceramics and metals. This technique can be simply described as applying an oscillating force to a sample and analysing the material response to that force (Fig. 3.7). For an applied stress varying sinusoidally with time, a viscoelastic material will also respond with a sinusoidal strain for low amplitudes of stress (Eq. 6 and 7, where $\omega$ is frequency of strain oscillation, $t$ is time and $\delta$ is phase lag between stress and strain).

The strain $(\varepsilon)$ of a viscoelastic body is out of phase with the stress $(\sigma)$ applied, by the phase angle ( $\delta)$. This phase lag is due to the excess time necessary for molecular motions and relaxations to occur. For a perfectly elastic solid, the resulting strain and the stress will be perfectly in phase. For a purely viscous fluid, there will be a 90 degree phase lag of strain with respect to stress. Viscoelastic polymers have intermediate characteristics; therefore some phase lag will occur during DMA tests.

The equations describing the basis concept of DMA testing are:

$$
\begin{gathered}
\sigma=\sigma_{0} \sin (\omega \cdot t+\delta) \\
\varepsilon=\varepsilon_{0} \sin (\omega \cdot t)
\end{gathered}
$$

E moduli can be expressed as complex number:

$$
E=E^{\prime}+i E^{\prime \prime}
$$

The storage modulus $\left(E^{\prime}\right)$ measures the stored energy, representing the elastic portion, and the loss modulus ( $E^{\prime \prime}$ ) measures the energy dissipated as heat, representing the viscous portion. The storage and loss moduli are defined as follows:

$$
\begin{gathered}
E^{\prime}=\frac{\sigma_{0}}{\varepsilon_{0}} \cos \delta \\
E^{\prime \prime}=\frac{\sigma_{0}}{\varepsilon_{0}} \sin \delta
\end{gathered}
$$

And the phase angle: 


$$
\tan \delta=\frac{E^{\prime \prime}}{E^{\prime}}
$$

DMA experiences were carried out on a DMA/SDTA 861e, (Mettler Toledo, Fig. 3.17.a), in the compression mode (Fig. 3.17.b). The samples were measured at a frequency of $1 \mathrm{~Hz}$. The storage modulus, $\left(E^{\prime}\right)$, loss modulus, $\left(E^{\prime \prime}\right)$, and loss tangent or loss factor, ( $\left.\tan \delta\right)$, were obtained using a compression geometry in a parallel plate measurement system. All the experiments were performed between $0^{\circ} \mathrm{C}$ and $190-200^{\circ} \mathrm{C}$ at a heating rate of $3^{\circ} \mathrm{C} / \mathrm{min}$. The applied static force to fix the sample was $18 \mathrm{~N}$ and it was chosen a dynamic strain of $120 \%$ or $30 \mu \mathrm{m}$ of deformation, so that the DMA equipment applies a dynamic force until one of both conditions is reached. Test specimens were prepared in a cylindrical shape with a diameter of $12 \mathrm{~mm}$ and a thickness of 4 to $6 \mathrm{~mm}$, approximately. At least three experiments were carried out for each sample. Tests were carried out applying the stress in the growing direction of the foam (y direction).
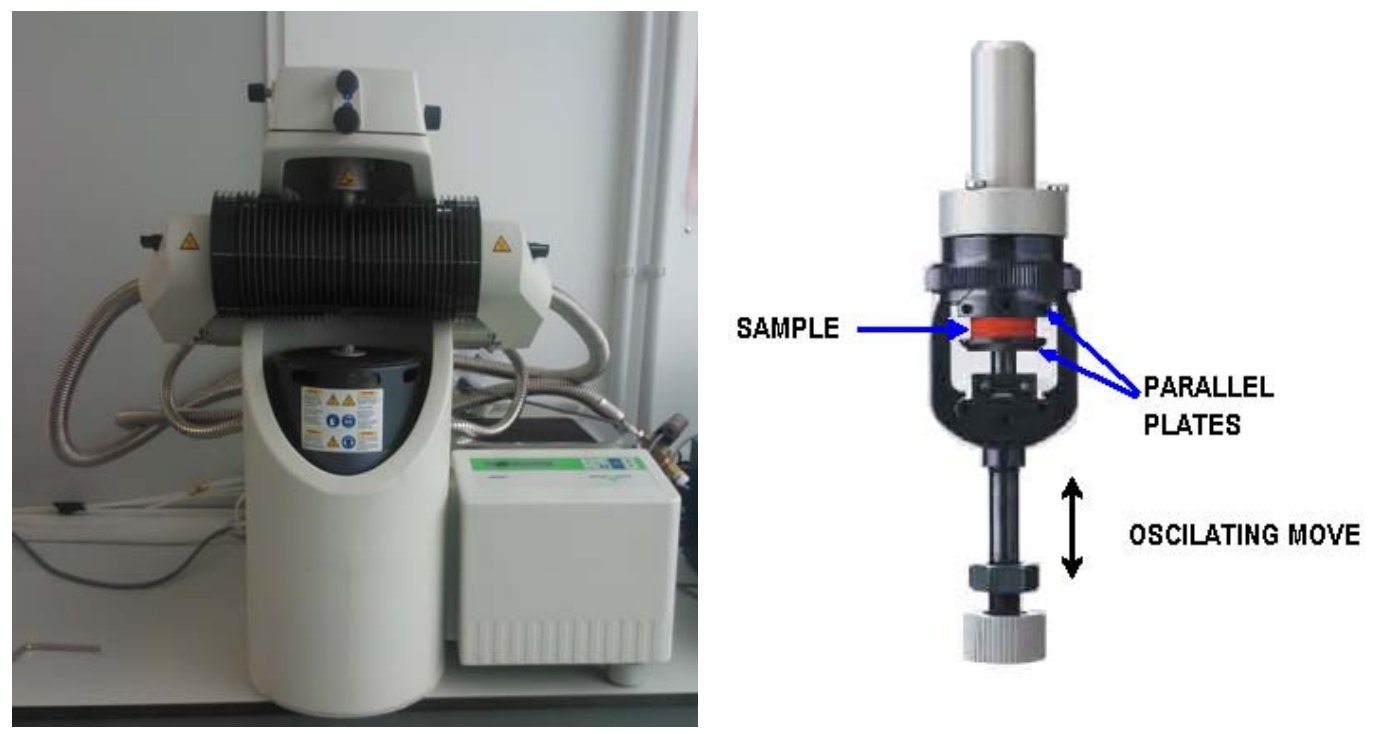

FIGURE 3.17. a) DMA/SDTA 861e; b) Compression clamp

\subsubsection{Thermal conductivity}

Two different equipments were employed in order to measure thermal conductivity: a rapid $\mathrm{K}$ heat flow meter from Holometrix and a hot-disk transient plane source thermal constant analyser from Hotdisk (TPS). The selection of the technique to measure was made 
depending on the sample size available to perform the measurements. So, only in the samples with enough amount of material (ideally a sheet of material with dimensions $300 \times 300 \mathrm{~mm}$ ) Holometrix device was employed. In other cases, the TPS technique was selected.

\subsubsection{Rapid K Heat Flow Meter}

A Rapid K Heat Flow Meter from Holometrix (Fig. 3.18) was used for the thermal measurements. Heat flow through the test sample (q) results from having a temperature gradient $(\Delta T)$ across the material. The thermal conductivity $\lambda$ is defined according to Fourier's equation:

$$
q=\lambda A \frac{\Delta T}{d}
$$

Where $A$ is the cross-sectional area of the sample and $d$ is the sample thickness.
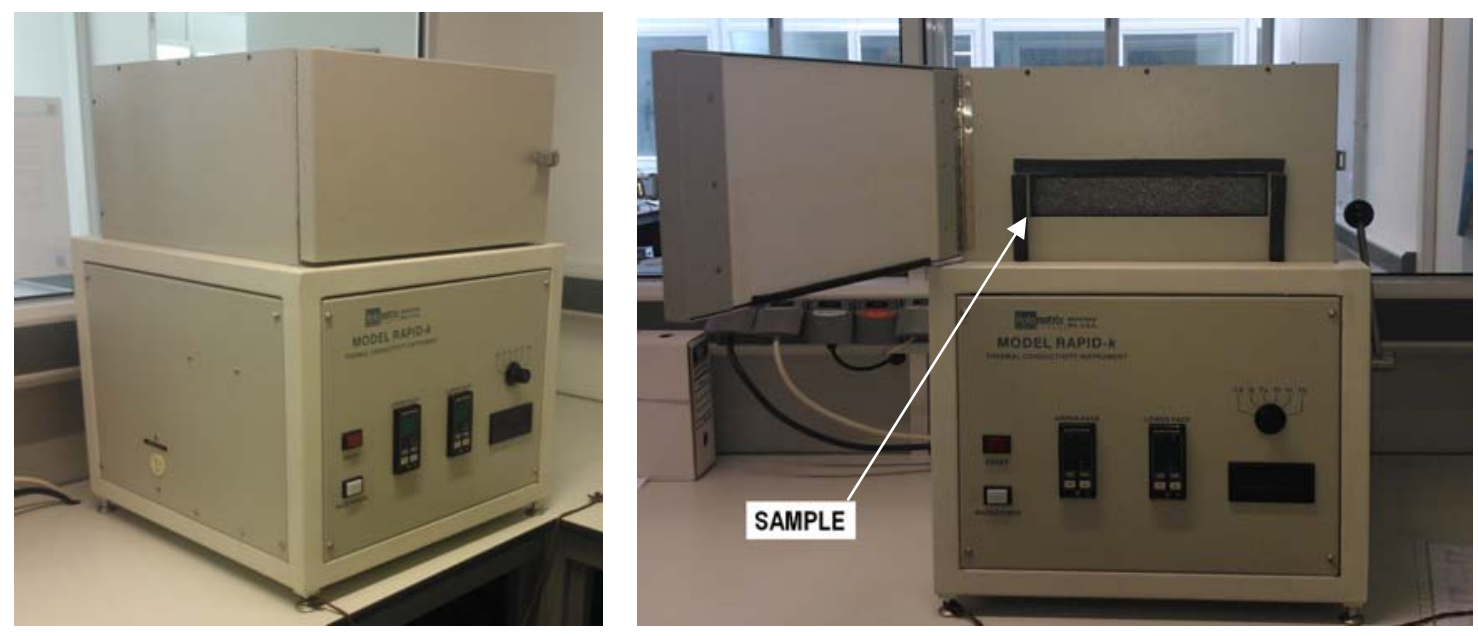

FIGURE 3.18.- Rapid K Heat Flow Meter, from Holometrix

The heat flow meter is a thermopile which gives an output of $40 \mu \mathrm{V}$ for a temperature drop of 1 으. It is a $100 \mathrm{~mm}$ side square which occupies the central portion of the cold face of the equipment. The total face area is a square of $305 \mathrm{~mm}$ side, the remaining portion acts as a shield that keeps the heat flown uniform in the central measurement section. The method is not absolute, and therefore needs to be calibrated using a standard sample. Once this has been done, the heat flow per unit area can be found from the reading of the heat flow transducer, and the thermal conductivity of the sample can thus be calculated using the previous equation.

Measurements were made under steady state heat flow conditions through the test sample. These were done in accordance with UNE12667 method. A dispersion of less than $1 \%$ in two consecutive readings was taken as a criterion to ensure that the measurements were 192 
done under steady state conditions. The time lap between readings was 10 minutes. Except some measurements carried out to evaluate the evolution of thermal conductivity with time, the rest of measurements were performed 12 days after foams manufacture, with the aim that all $\mathrm{CO}_{2}$ created during foaming had diffused out to atmosphere and only air is inside the foams. The measurements were performed at 10, 20, 25, 40 and 50 ㅇ. E. Each experiment was repeated 5 times in order to obtain an average value.

\subsubsection{Transient Plane Source}

A hot-disk transient plane source (TPS) thermal constant analyser was also used for the measurement of thermal conductivity of polyurethane foams produced in this study. The basic principle of this method relies on a plane element which acts both as temperature sensor and heat source. This element consists of an electrically conducting pattern of thin nickel foil (10 $\mu \mathrm{m}$ ) spiral shaped, embedded in an insulating layer usually made of Kapton (70 $\mu \mathrm{m}$ thick) (Fig. 3.19.a). The TPS element is located between two samples with both sensor faces in contact with the two samples surfaces as is shown in Fig. 3.19.b. Two samples of similar characteristics are required for this purpose. Measurements were made in accordance with ISO 22007-2:2008 $\operatorname{method}^{13}$.

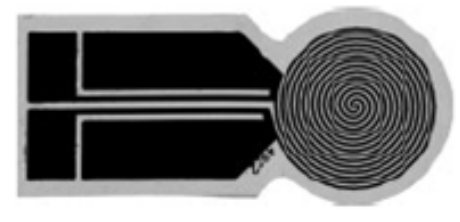

(a)

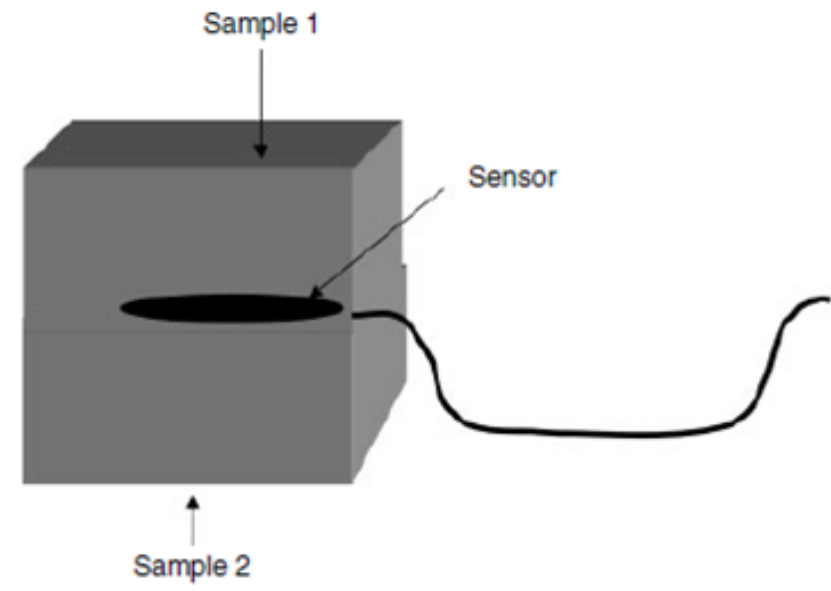

(b)

FIGURE 3.19. (a) TPS method sensor; (b) schematic diagram of the experimental setup.

This method presents some advantages in comparison with standard methods, such as fast and easy experiments, a wide range of thermal conductivities accessible (from 0.02 to 400 $\mathrm{W} / \mathrm{m} \cdot \mathrm{K})$, marginal effort needed in sample preparation, flexibility in sample size and possibility to perform local or bulk measurements with only changing the sensor diameter. On the other 
hand, a drawback is that this is a contact method, so special care is needed in the experimental procedure in order to obtain reliable, reproducible results.

As for the theory that underlies this technique, a constant electric power supplied to the sensor results in an increase in temperature $\Delta T(t)$ which is directly related to the variation in the sensor resistance $R(t)$ by the equation:

$$
R(t)=R_{0}[1+\alpha \Delta T(t)]
$$

Where $R_{0}$ is the nickel electrical resistance in the beginning of the recording (initial resistance), $\alpha$ is the temperature coefficient of resistance of the nickel foil, and $\Delta T(t)$ is the temperature increase of the sensor with time.

Assuming an infinite sample and the conductive pattern being in the XY plane of a coordinate system, the temperature rise at a point $(x, y)$ at $t$ time is obtained by solving the equation for the heat conduction, which relates temperature change with time. In the particular case of the employed sensor geometry with $\mathrm{n}$ concentring ring sources, the spatial average $\overline{\Delta T(\tau)}$ can be obtained through the equation:

$$
\overline{\Delta T(\tau)}=P_{0}\left(\pi^{3 / 2} a \cdot \lambda\right)^{-1} D(\tau)
$$

where $P_{0}$ is a Bessel function, $D(\tau)$ is a geometric function characteristic of the number of " $n$ " concentric rings, and $\overline{\Delta T(\tau)}$ is the temperature increase of the sensor expressed in terms of the only variable $\tau$, defined as:

$$
\tau=(t / \theta)^{1 / 2} ; \theta=a^{2} / \kappa
$$

where $t(s)$ is the measured time from the start of the transient heating, $\theta$ is the characteristic time, which depends both on parameters of the sensor and the sample, $a(\mathrm{~mm})$ is the sensor radius and $\kappa\left(\mathrm{mm}^{2} / \mathrm{s}\right)$ is the thermal diffusivity of the sample. The characteristic time needs to be in the range from 0.5 to 1.5 to guarantee that the theoretical assumptions are kept, thus the heat flow is an ellipsoid of neither too high nor too low sphericity.

Thermal conductivity can be obtained by fitting the experimental data to the straight line given by equation (14); thermal diffusivity is calculated from equation (15) taking into account the $\tau$ value determined in the previous fit.

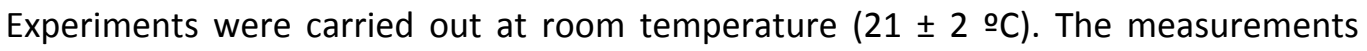
were performed using two square samples of $40 \mathrm{~mm}$ side and around $30 \mathrm{~mm}$ thickness. A disk- 
shaped TPS sensor with diameter $6.403 \mathrm{~mm}$ was used in all measurements. Due to the limited amount of material available for this measurement and the requirement of a flat surface, the TPS sensor was located in contact with the xy plane of the sample (see Fig. 3.3).

Measurements were performed enough time after foam production (more than one month late) to ensure a time stability of them. So, the diffusion of the $\mathrm{CO}_{2}$ resulting from the foaming reaction (with lower heat transfer coefficient than air) has been completed, and the gas inside cells was air in all samples. Thereby, the measurements were made avoiding any difference due to the kind of gas present inside the cells.

\subsubsection{Extinction coefficient}

Transmittance measurements in the infrared region where performed with 5 thin samples, where the thickness $(L)$ range was between 0.5 and $2.5 \mathrm{~mm}$. Studied surface was in the $x y$ plane (see Fig. 3.3). The sample diameter and beam diameter were 12 and $1.5 \mathrm{~mm}$, respectively. Infrared spectra were collected with a Bruker Tensor 27 FTIR spectrometer (Fig. 3.20) with a DLATGS (deuterated L-a-alanine doped with tryglicine sulfate) detector in the transmission mode, with a resolution of approximately $2 \mathrm{~cm}^{-1}$.

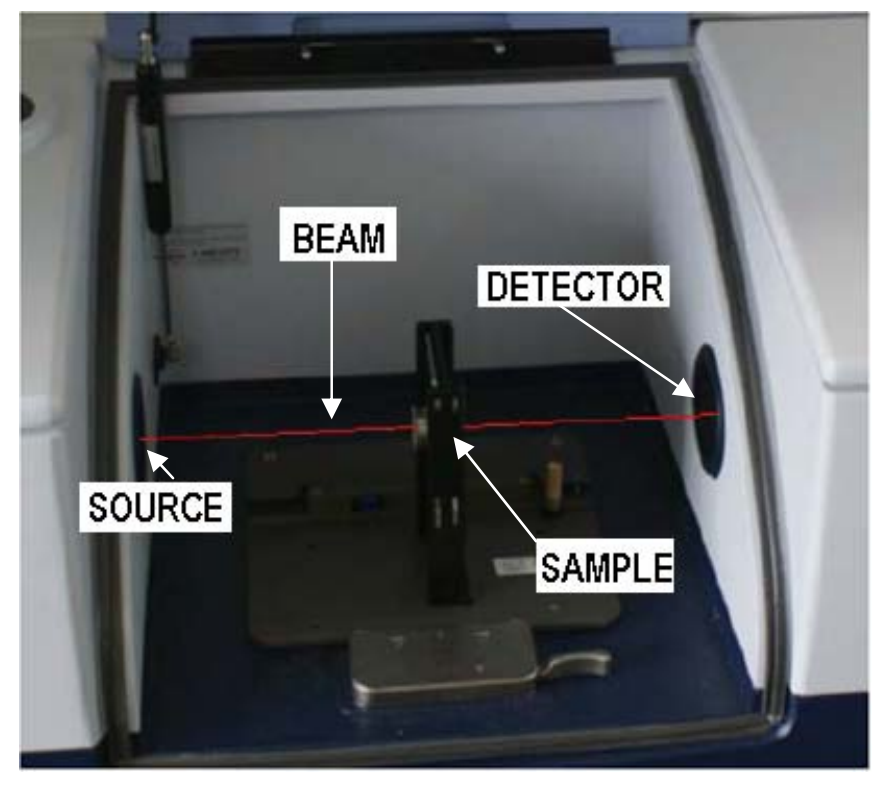

FIGURE 3.20.- Bruker Tensor 27 FTIR spectrometer in the transmission mode

As the first stage of the measurement process, the background was registered to eliminate $\mathrm{H}_{2} \mathrm{O}$ and $\mathrm{CO}_{2}$ contributions. Later, transmittance spectra were taken for samples of 
various thicknesses. The transmittance $\left(\tau_{n, \lambda}\right)$ is the ratio of the intensity transmitted through the sample $\left[I_{\lambda}(x)\right]$ to the intensity without the sample $\left[I_{0, \lambda}\right]$ :

$$
\tau_{n, \lambda}=\frac{I_{\lambda}(x)}{I_{0, \lambda}}
$$

Transmission measurements were performed in the wave number infrared region from 4000 to $400 \mathrm{~cm}^{-1}$. The data supplied by the software were a collection of 1865 values in this range. With the measured data for samples with different thickness, it was possible to determine the extinction coefficient of each foam using the calculation explained in section 5.3.2.3.

\subsubsection{Reaction kinetics}

Several chemical reactions and several ingredients are involved in the formation of polyurethane foams. Infrared spectroscopy is usually employed for the study of this process ${ }^{14}$, as polymerisation kinetics is able to be observed with this technique.

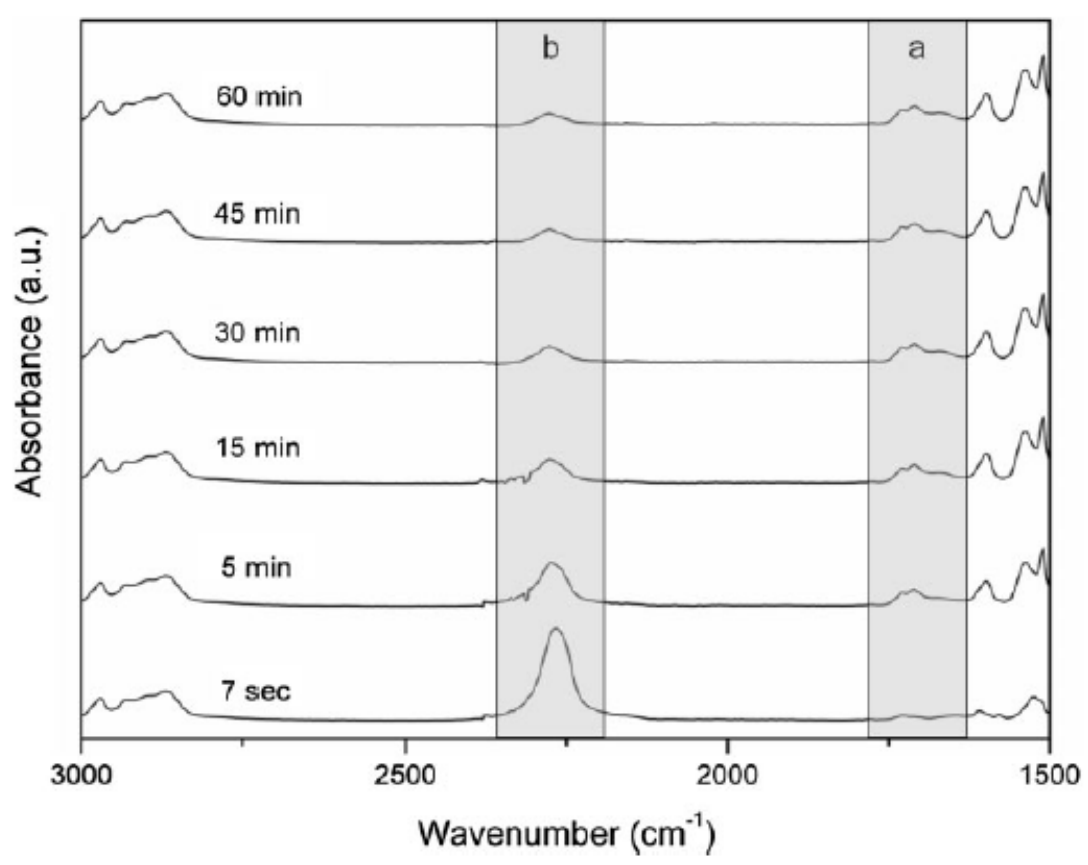

FIGURE 3.21.- Infrared spectra of PU sample at different reaction times illustrating the evolution of (a) the carbonyl region and (b) the isocyanate absorbance band ${ }^{14}$

In the present work, one region has been observed for the analysis of the infrared spectra of polyurethanes (Figure $3.21, \mathrm{~b}$ ): the isocyanate absorbance band approximately at 
$2270 \mathrm{~cm}^{-1}$. The variation of the area under this curve respect to its initial value has allowed studying the variation in the polymerization rate by the presence of nanoparticles.

\subsection{Microscopic Techniques}

\subsubsection{SEM}

Quantitative image analysis was used to quantify the cellular structure of the different samples. For this purpose, cured foams were cut to provide a smooth surface, which, after vacuum coating with gold, were examined by Scanning Electron Microscopy (SEM) using a JEOL JSM 820 equipment (Figure 3.22).

ImageJ special software developed in the CellMat Laboratory ${ }^{15}$ was employed for cell size quantification, and at least 100 cells were measured in each material. Cell size distribution, average cell size and anisotropy ratio (quotient between the cell size in the growing direction (y) and the average cell size in the perpendicular plane to the growing direction ( $x z$ plane)) were measured.

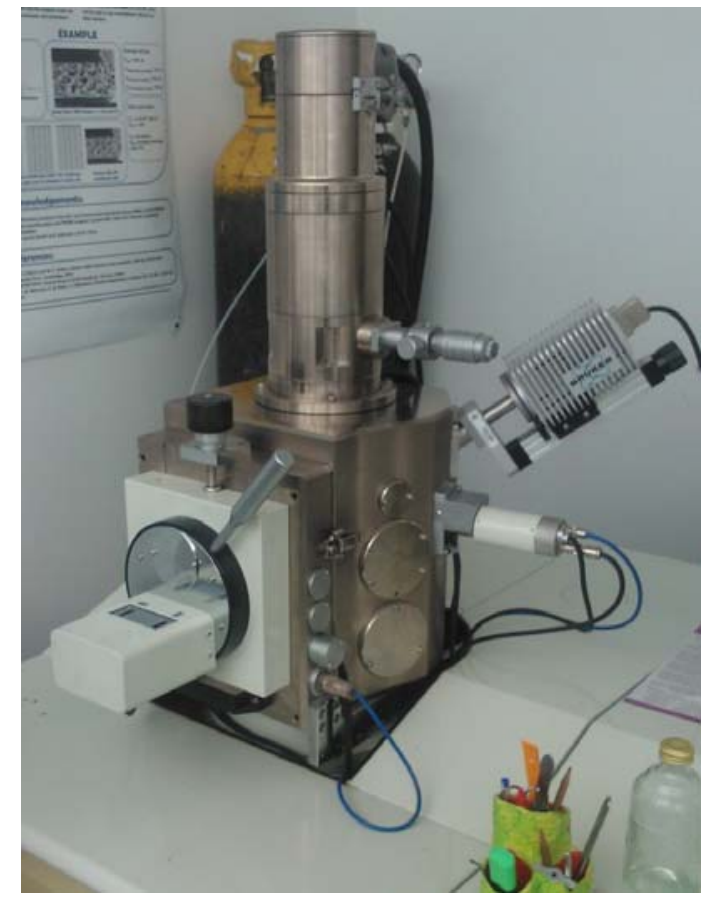

FIGURE 3.22 Scanning Electron Microscopy (SEM) JEOL JSM 820

The width of the cell size distribution was calculated using the normalized standard distribution parameters (NSD): 


$$
N S D=\frac{\left(\sum_{i}\left(m_{i}-\sum_{i} m_{i} f_{i}\right)^{2} f_{i}\right)^{1 / 2}}{\sum_{i} m_{i} f_{i}}
$$

Where $n_{i}$ represents the number of cells with a size between $a_{i}$ and $b_{i}, n$ is the total number of analysed cells, $m_{i}=\left(a_{i}+b_{i}\right) / 2$ and $f_{i}=n_{i} / n$. Data with a bimodal distribution will have a larger NSD value than data with a mono-modal distribution.

The asymmetry coefficient (AC) of the distribution was also calculated, based on the cell size measurements, using Eq. 18. This coefficient gives information about the cell size distribution asymmetry with respect to it mean value

$$
A C=\frac{n}{(n-1)(n-2)} \sum_{i}\left(\frac{x_{i}-\bar{x}}{s}\right)^{3}
$$

where $n$ is the number of cells, $s$ is the sample standard deviation and $\bar{X}$ is the average cell size.

\subsubsection{Open cell content}

Open-cell can be defined as the relation between the interconnected cells volume and the total gas volume (Eq. 19).

$$
\text { OC }(\%)=\frac{\text { Interconected cells volume }}{\text { Total gas volume }}
$$

These measurements were performed with an air pycnometer (Eijkelcamp 08.06 Langer, Fig 3.23). The measured sample is placed in the vacuum bell. By means of a mercury column an under-pressure is created in the bell. Depending on the volume of gas in the bell, more or less air will be withdrawn. The volume of air depends on the volume of the object to be measured. The mercury column in the glass tube will drop along with lowering the level vessel and will indicate the object's volume on the calibrated scale. Volumes between 0 and $115 \mathrm{~cm}^{3}$ can be read directly from the scale, this is the apparent volume of the sample. 


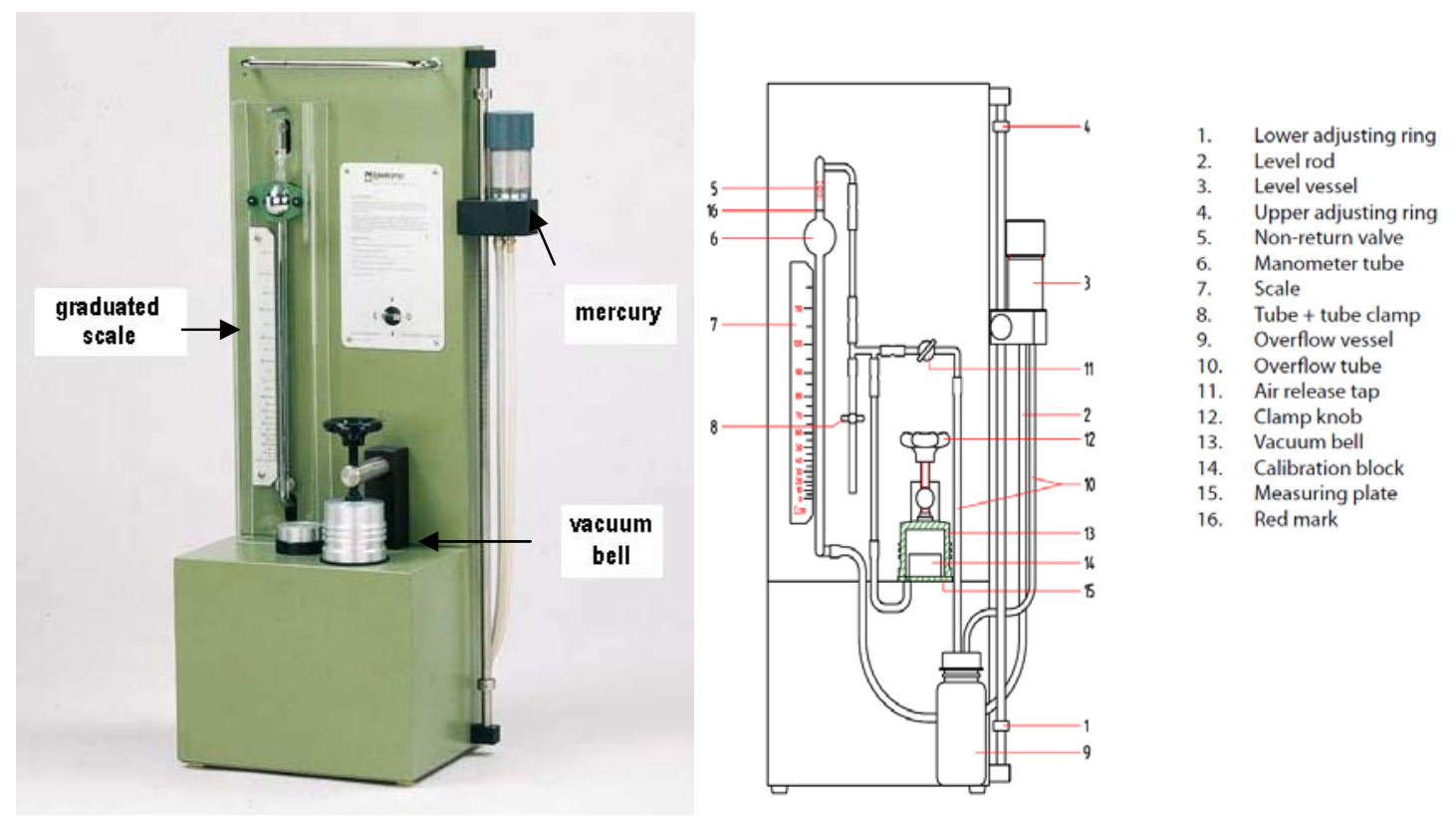

FIGURE 3.23. Eijkelcamp 08.06 Langer pycnometer to measure the open cell content: external aspect (left image); internal scheme (right image)

The following equation was used according to the ASTM D6226 $6^{16}$ to calculate the open cell content:

$$
\text { OC }(\%)=\frac{V_{\text {Sample }}-V_{\text {Pycnometer }}}{V_{\text {Sample }} \cdot p}
$$

where the geometrical volume, $V_{\text {Sample }}$ (calculated from the specimen dimensions), is subtracted from the total volume measured with the pycnometer $\left(V_{\text {Pycnometer }}\right)$, and divided by the volume of air contained in the sample, $V_{\text {Sample }} \cdot p$, where $p$ is the sample porosity calculated using $1-\left(\rho_{\text {foam }} / \rho_{\text {solid }}\right)$, in which $\rho_{\text {foam }}$ is the foam density and $\rho_{\text {solid }}$ is the density of the polyurethane matrix, in this case $\rho_{\text {solid }}=1100 \mathrm{~kg} \cdot \mathrm{m}^{-3}$.

Cubic samples with lateral dimensions of $30 \mathrm{~mm}$ were employed. A correction due to cells cut present in the samples surface was made in accordance with ASTM D6226 ${ }^{17}$. Therefore, the volume of cells at the surface was taken into account in order to eliminate their effect in the final value of the open cell content. 


\subsubsection{X-ray tomography}

Micro tomography scans were performed using a X-ray customized equipment built at the Centre for X-ray Tomography at Ghent University (UGCT) ${ }^{18}$. These experiments were used to experimentally obtain the mass fraction in the struts of the samples. This particular setup consists in a microfocus X-ray tube FXE- 160.50 source from Feinfocus (minimal spot size: 0.9 $\mu \mathrm{m}$, Voltage: $20-160 \mathrm{kV}$, Current: 0-200 $\mu \mathrm{A}$ ) with a maximum output power of $20 \mathrm{~W}$, and a detection system PerkinElmer XRD 1620 CN3 CS a-Si flat panel with CsI screen (2048 x 2048, $200 \mu \mathrm{m}$ pixel size). A rotary stage from MICOS (UPR-160F AIR) was placed in between these two basic components. It was mounted over a linear stage which allows for movement in a wide gap (1.4 $\mathrm{m}$ approx.) in between the source and the detector varying the magnification factor, M, as described in Eq. (21) (SDD: source detector distance, SOD: source-object distance). Some extra piezoelectric components facilitate the sample centring.

$$
M=\frac{S D D}{S O D}
$$

Two scanner settings were used for and SDD $=1388.28 \mathrm{~mm}$ with a SOD $=34.70 \mathrm{~mm}(\mathrm{M}$ $=40)$ and $S O D=17.35(\mathrm{M}=80)$ used according to foam samples requirements. The higher magnification choice permitted to resolve better the cell walls (double resolution) although the field of view was also reduced by a factor of 2 .

A tube voltage bellow $60 \mathrm{kV}$ and tube currents ranging 160-170 $\mu \mathrm{A}$ were used, the detector exposure time was $4000 \mathrm{~ms}$, the rotation step size was $0.2^{\circ}$ and the total scan time was $2 \mathrm{~h}$. Once the projections were acquired, the reconstruction of the tomogram was done using the Octopus, server/client reconstruction package ${ }^{19}$.

The determination of the mass fraction in the struts starting from the microtomography measurements was performed using the method proposed in ref. 16.

\subsubsection{X-ray diffraction}

In this technique the radiation from an $\mathrm{X}$-ray tube (with a $\lambda$ wavelength) impacts over a sample. The incident beam is reflected with an angle according with Bragg Law (see Eq. 22 and Fig. 3.2.3), where $n$ is an integer (diffraction order), $\lambda$ is the wavelength of incident wave, $d$ is the spacing between the planes in the atomic lattice, and $\theta$ is the angle between the incident beam and the scattered beam. A moving detector, varying the angle with respect to the sample, detects the diffracted beam. With the help of the intensity as a function of the angle it 100 
is possible to obtain information about the crystalline structure of the sample, such as for instance interplanar distance.

$$
\sin \theta=\frac{n \lambda}{2 d}
$$

Applying this technique to nanoclays it is possible to know the interplanar distance in the pure nanoclays, and the variation of this characteristic when the nanoclays are infused in polyurethane; i.e. it is possible to know the intercalation/exfoliation state of the nanoparticles in the composite.

X-ray diffraction experiments for this thesis were performed using a X-ray equipment (Bruker Discover D8 in a Bragg-Brentano geometry, see Fig. 3.23.a, equipped with LynxEye detector, see Fig.3.23.b) at the Laboratory of Instrumental Techniques (LTI) from the University of Valladolid. This facility employs a $\mathrm{Cu}(\mathrm{K} \alpha)$ as $\mathrm{X}$-ray generator, and for the performed measurements a power of $40 \mathrm{KV}$ and $30 \mathrm{~mA}$ of current. A blade of $0.6 \mathrm{~mm}$ was employed for collimating the beam. Studied angles varied from 0.5 to 10 . Parallel faces samples of $48 \times 15 \times 2$ $\mathrm{mm}^{3}$ were prepared for these experiments, with the orientation respect to the growing direction showed on Fig. 3.23.c. Incident beam was applied over $x y$ plane surface (i.e. a plane including the growing direction). Pure nanoclays samples were prepared compacting some nanoclays powder over the sample holder, generating a flat surface parallel to the sample holder.

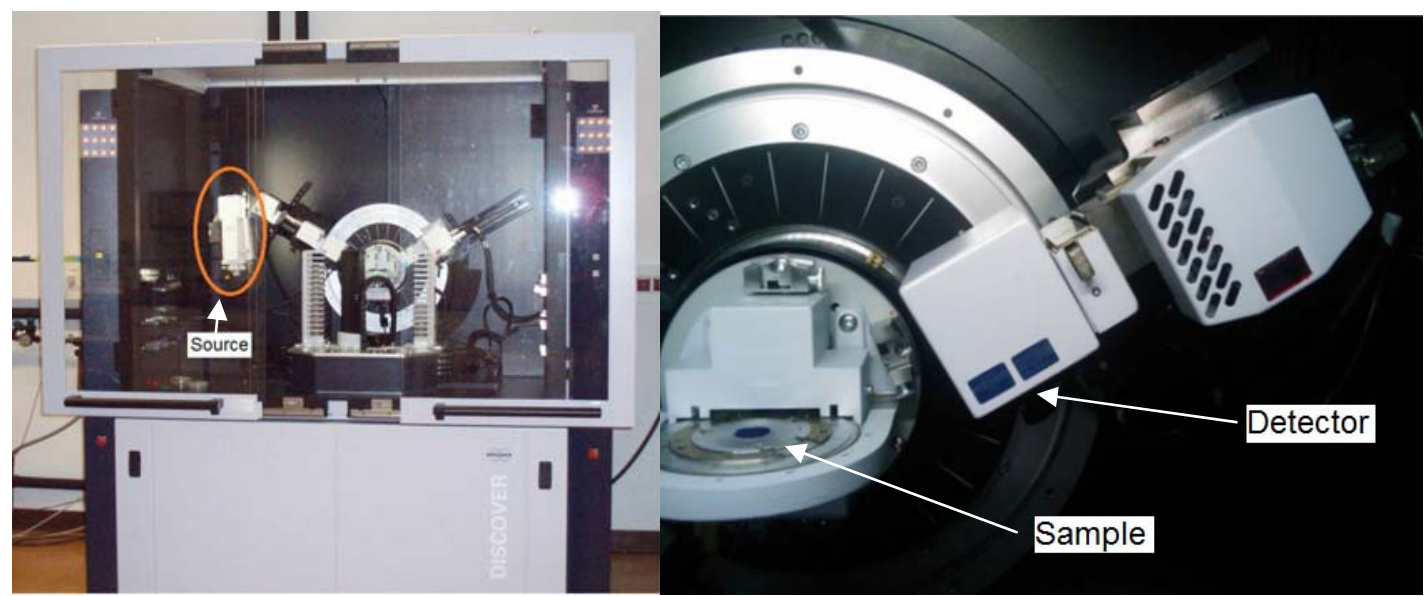

(a)

(b) 
Chapter 3: Materials And Characterisation Techniques

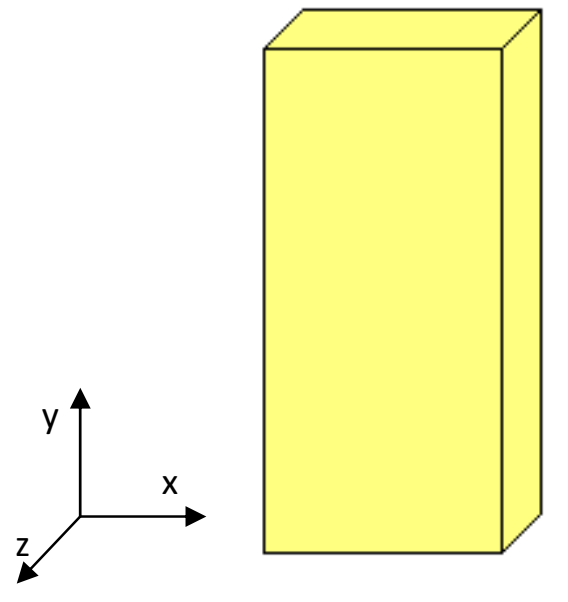

(c)

FIGURE 3.24.- (a) Bruker D8 Discover; (b) Detail of the Lynx Eye detector; (c) Orientation of the studied samples with $\mathrm{x}$-ray diffraction. 
1 J. Ren, A. S. Silva, R. Krishnamoorti, Linear viscoelasticity of disordered polystyrenepolyisoprene block copolymer based layered-silicate nanocomposite, Macromolecules, 33, 3739-3746, (2000)

${ }^{2}$ M. J. Solomon, A. S. Almussallam, K. F. Seefeldt, A. Somwangthanaroj, P. Varadan, Rheology of polypropylene/clay hybrid materials. Macromolecules, 34, 1864-1872, (2001)

${ }^{3}$ R. Wagener, T. J. G. Reisinger, A rheological method to compare the degree of exfoliation of nanocomposites, Polymer, 44, 7513-7518, (2003)

4 J. Zhao, B. Morgan, J.D. Harris, Rheological characterization of polystyrene-clay nanocomposites to compare the degree of exfoliation and dispersion, Polymer, 46, 8641-8660, (2005)

${ }^{5}$ F. J. Galindo-Rosales, P. Moldenaers, J. Vermant, Assessment of the dispersion quality in polymer nanocomposites by rheological methods, Macromolecular Materials and Engineering, 296 (3-4), 331-340, (2011)

6 J. Vermant, S. Ceccia, M. K. Dolgovskij, P. L. Maffetone, C.W. Macosko, Quantifying dispersion of layered nanocomposites via melt rheology, Journal of Rheology, 52, 429-450, (2007)

${ }^{7}$ H.H. Winter, Three views of viscoelasticity for Cox-Merz materials, Rheologica acta, 48(3), 241-243, (2009)

${ }^{8}$ F. Li, K. Lania, X. Wang, G. Xue, H. H. Winter, Steric effects on the rheology of nanocomposite gels of organoclay in dicarboxyl-terminated polybutadiene, Soft Matter, 6, 2442-2448, (2010)

${ }^{9}$ ASTM D1622 - 08: Standard Test Method for Apparent Density of Rigid Cellular Plastics, ICS Number Code 83.100 (Cellular materials), DOI: 10.1520/D1622-08

${ }^{10}$ ASTM D1621: Standard Test Method for Compressive Properties Of Rigid Cellular Plastics, ICS Number Code 83.100 (Cellular materials), DOI: 10.1520/D1621-10

11 EN ISO 178, Plastics - Determination of flexural properties, European Committee for Standardization (CEN), (2010) 
12 UNE-EN 12667:2002, Thermal performance of building materials and products. Determination of thermal resistance by means of guarded hot plate and heat flow meter methods, Products of high and medium thermal resistance, (2002)

${ }^{13}$ ISO 22007-2. 2008. Plastics-Determination of Thermal Conductivity and Thermal DiffusivityPart 2: Transient Plane Heat Source (Hot Disc) Method.

${ }^{14}$ M.M. Bernal, I. Molenberg, S. Estravis, M. A. Rodriguez-Perez, I. Huynen, M. A. Lopez-Manchado, R. Verdejo, Comparing the effect of carbon-based nanofillers on the physical properties of flexible polyurethane foams, Journal of Materials Science, 47(15), 5673-5679, (2012)

${ }^{15}$ J. Pinto, E. Solórzano, M. A. Rodriguez-Perez, J. A. de Saja, Characterization of the cellular structure based on user-interactive image analysis procedures, Journal of Cellular Plastics, 49(6), 555-575, (2013)

${ }^{16}$ ASTM D6226 - 10: Standard Test Method for Open Cell Content of Rigid Cellular Plastics, ICS Number Code 83.080.01 (Plastics in general), DOI: 10.1520/D6226-10

${ }^{17}$ ASTM D6226 - 10: Standard Test Method for Open Cell Content of Rigid Cellular Plastics, ICS Number Code 83.080.01 (Plastics in general), DOI: 10.1520/D6226-10

${ }^{18}$ S. Pardo-Alonso, E. Solórzano, L. Brabant, P. Vanderniepen, M. Dierick, L. Van Hoorebeke, (3d) Analysis of the Progressive Modification of the Cellular Architecture in Polyurethane Nanocomposite Foams via X-Ray Microtomography, European Polymer Journal, 49(5), 9991006, (2013)

19 J. Vlassenbroeck, M. Dierick, B. Masschaele, V. Cnudde, L. Van Hoorebeke, P. Jacobs Software tools for quantification of X-ray microtomography at the UGCT, Nuclear Instruments and Methods in Physics Research Section A: Accelerators, Spectrometers, Detectors and Associated Equipment, 580(1), 442-445, (2007) 
CHAPTER 4:

\section{INFUENCE OF THE FORMULATION AND DISPERSION TECHINIQUE EMPLOYED}





\section{INFLUENCE OF THE FORMULATION AND DISPERSION TECHNIQUE EMPLOYED}

\subsection{Objectives}

The first approach adopted to obtain a better understanding of nanoclays-polyurethane interaction has been to study the influence of different formulations and different dispersion techniques on the final foam properties. For this reason, the properties of rigid PU foams filled with nanoclays, and the effect of the use of different dispersion procedures have been studied. The objective was to show which properties are suitable to be improved, as polyurethane has a wide range of applications, and the possible influence of the dispersion procedure. For this aim, an initial study with three different polyurethane blends (with different viscosities, as polyol viscosity plays a fundamental role that could affect the dispersion effectiveness) was performed in collaboration with the Katholic University of Leuven (KUL), under Professor Moldenaers supervision, in order to select the most sensitive formulation to the dispersion technique. Then, this formulation was selected and employed for production and characterisation of foams. Properties of these materials have been studied analysing the dependence of the final material properties with the used dispersion technique.

\subsection{Rheological study for the different dispersion techniques and different polyol blends}

\subsubsection{Results}

The polyol components of the three different rigid polyurethane foam formulations introduced in the Materials and Characterization Techniques chapter (table 3.1) were employed in this study. For the polyols with a lower viscosity BASF (LV) and Recticel (MV) two different concentrations of clays ( 1 and $3 \%$ by weight) were used. For the material of higher viscosity (HV) the analysis was conducted by adding $3 \%$ by weight of nanoclays.

Two different techniques were employed for the dispersion of the clays: low shear mixing and ultrasonication, listed according to a theoretical increasing dispersion power ${ }^{1,2}$. Their main characteristics, parameters employed and the short name that have been used in the tables and figures were presented in section 3.1 of chapter 3 (table 3.3). Dispersion quality was analysed by performing strain sweep and frequency sweep measurements. The results are presented for each type of polyol used. 


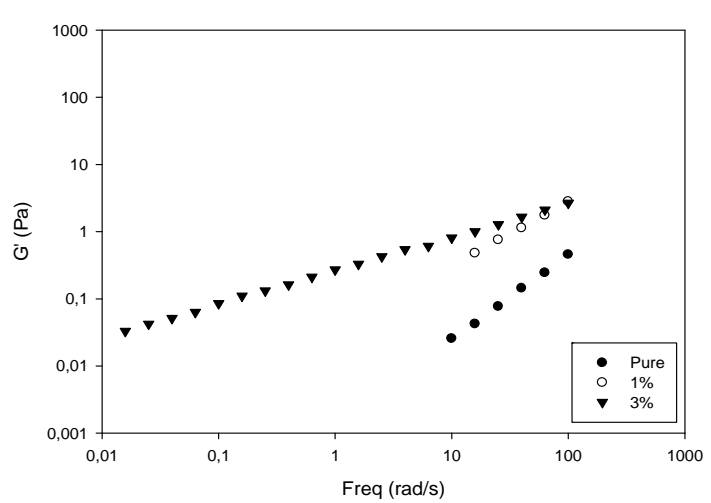

(a)

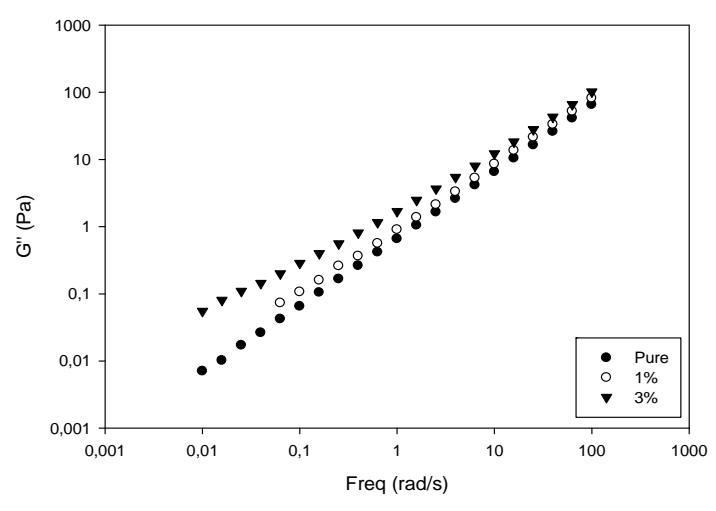

(b)

FIGURE 4.1: Frequency sweep at 23으, preshear of $1 \mathrm{~s}^{-1}$ for 5 minutes followed by an equilibration period of 25 minutes: (a) Storage modulus, (b) Loss modulus. Dispersions are prepared by shear mixing at $200 \mathrm{rpm}$ for 2 minutes.

The frequency sweep data for the BASF formulation are presented in figure 4.1 (shear mixing dispersion technique) and 4.2 (ultrasonication dispersion technique). A large difference is obtained between the two dispersion techniques used. The pure polyol from the BASF formulation is a viscous liquid; $G^{\prime}$ is almost no measurable and $G^{\prime \prime}$ is proportional to the frequency across the complete frequency range studied. By incorporating nanoclays dispersed with the low shear technique, both the elastic and viscous contribution rise, but the formation of a low frequency plateau is lacking (Figure 4. 1). This indicates that although there is a clear effect of the nanofillers, a percolating structure (indicating a well dispersed material) is not yet formed in the material for a concentration of clays of $3 \% \mathrm{wt}$.

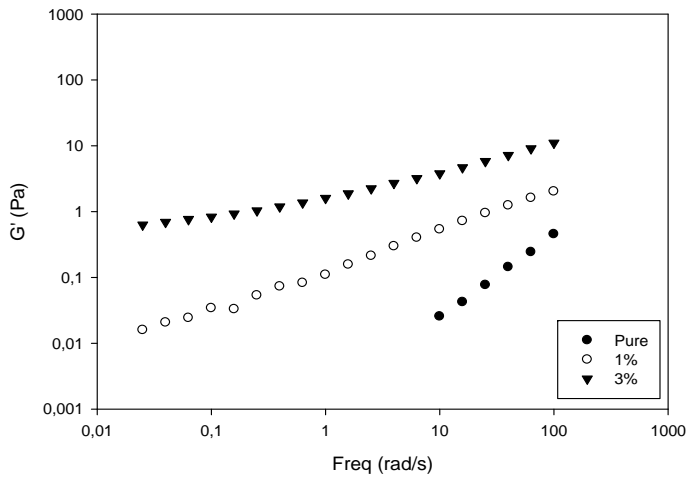

(a)

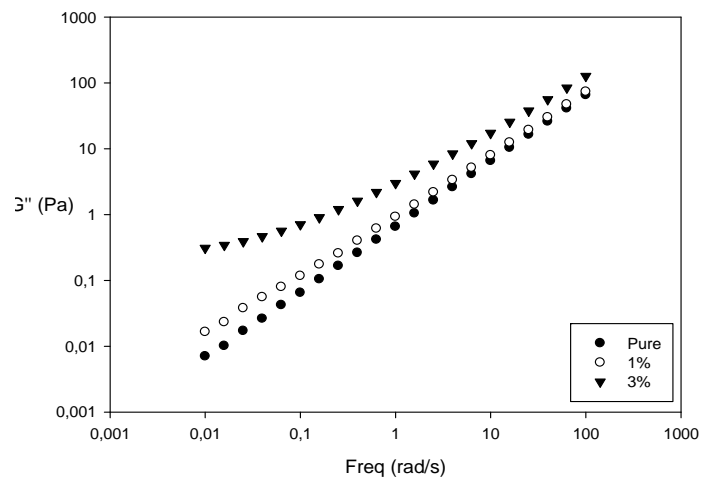

(b)

FIGURE 4.2: Frequency sweep at 23으, preshear of $1 \mathrm{~s}^{-1}$ for 5 minutes followed by an equilibration period of 25 minutes: (a) Storage modulus, (b) Loss modulus. Dispersions are prepared by applying ultrasonication for 25 minutes. 
Application of ultrasonication (Figure 4.2) shows a marked increase in both $\mathrm{G}^{\prime}$ and $\mathrm{G}^{\prime \prime}$ in comparison with pure polyol and with the data obtained when the clays are dispersed by using low shear mixing (Fig. 4.1). As the clay concentration reached $3 \%$ the beginning of a plateau in G' and G" at low frequencies can be distinguished, as indicator of a better dispersion.

\section{Recticel low viscosity (MV)}

The frequency sweep data for the low viscosity Recticel formulation are presented in Figures 4.3 (low shear dispersion technique) and 4.4 (ultrasonication dispersion technique). For this material, no significant differences are obtained between the two different preparation protocols.

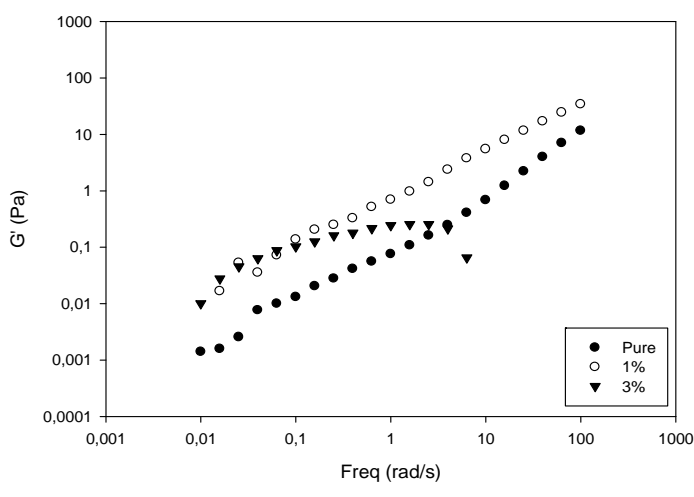

(a)

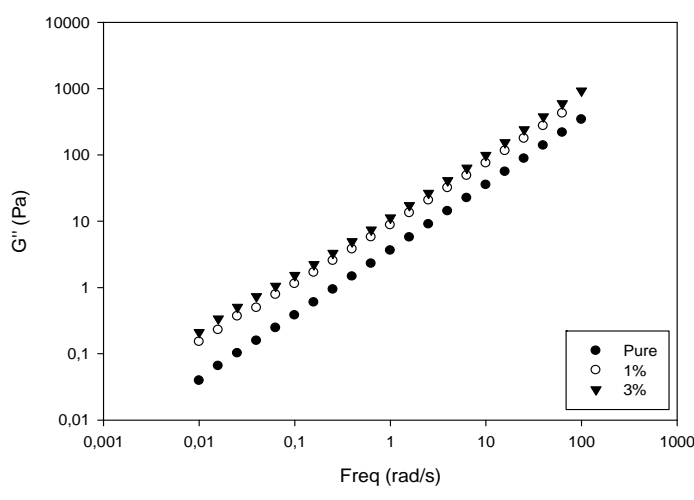

(b)

FIGURE 4.3: Frequency sweep at 23으, preshear of $1 \mathrm{~s}^{-1}$ for 5 minutes followed by an equilibration period of 25 minutes: (a) Storage modulus, (b) Loss modulus. Dispersions are prepared by mixing at 200 rpm for 2 minutes.

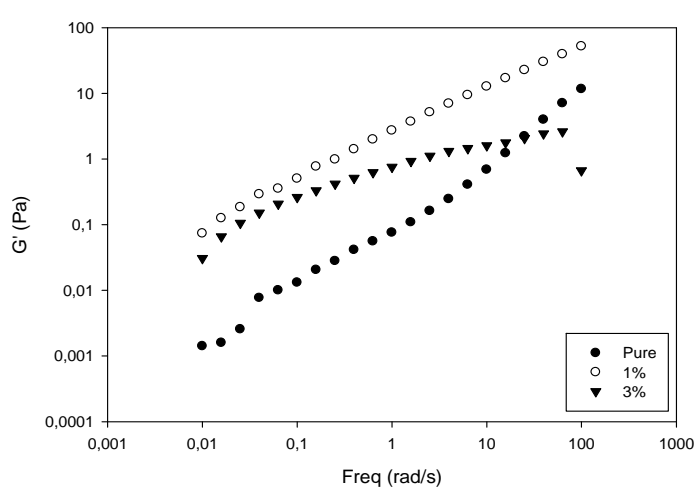

(a)

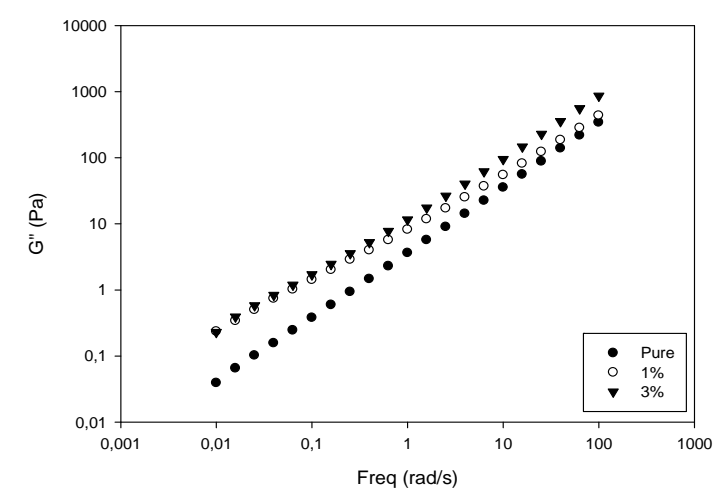

(b)

FIGURE 4.4: Frequency sweep at 23으, preshear of $1 \mathrm{~s}^{-1}$ for 5 minutes followed by an equilibration period of 25 minutes: (a) Storage modulus, (b) Loss modulus. Dispersions are prepared by applying ultrasonication for 25 minutes. 
The linear response of the pure material corresponds again to that of a viscous liquid (G" is proportional to the frequency and $G^{\prime}$ is smaller than $G^{\prime \prime}$ for the entire frequency range studied). The addition of nanoclays leads to the expected increase in G", but the response remains proportional to the frequency for both techniques (i.e. no plateau at low frequencies is detected). The data of $\mathrm{G}^{\prime}$ with increasing clay loading shows an interesting evolution, but it can be concluded from the data that no good dispersion is obtained in the polyol component with this Recticel formulation, independently from the dispersion technique employed.

\section{Recticel high viscosity (HV)}

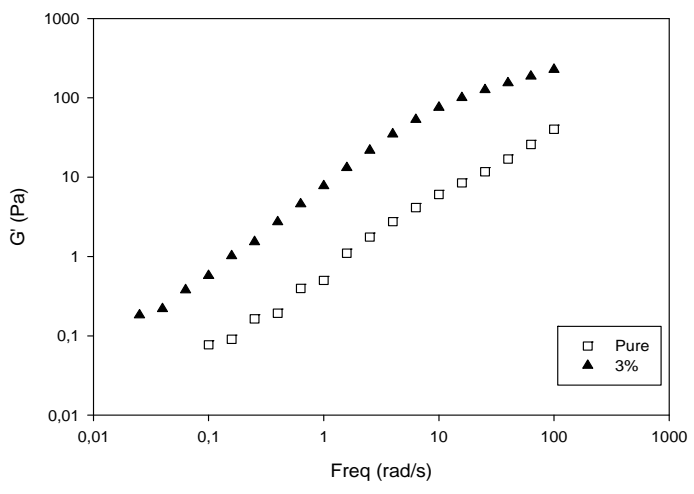

(a)

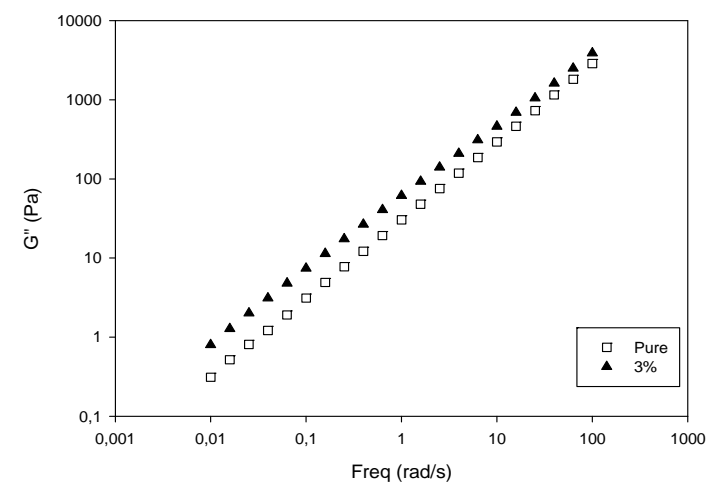

(b)

FIGURE 4.5: Frequency sweep at 23으, preshear of $1 \mathrm{~s}^{-1}$ for 5 minutes followed by an equilibration period of 25 minutes: (a) Storage modulus, (b) Loss modulus. Dispersions are prepared by mixing at 200 rpm for 2 minutes.

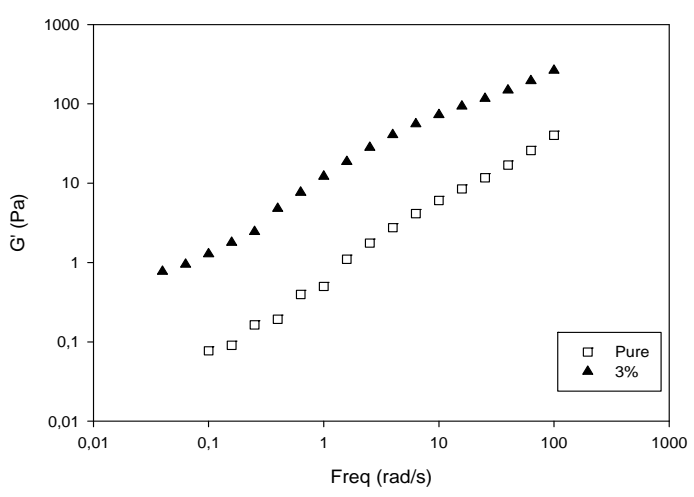

(a)

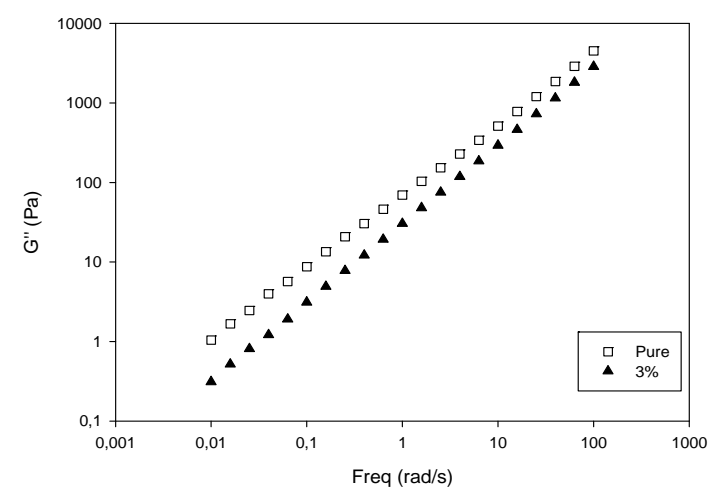

(b)

FIGURE 4.6: Frequency sweep at 23으, preshear of $1 \mathrm{~s}^{-1}$ for 5 minutes followed by an equilibration period of 25 minutes: (a) Storage modulus, (b) Loss modulus. Dispersions are prepared by applying ultrasonication for 25 minutes. 
The frequency sweep data for the high viscosity Recticel formulation are presented in figures 4.5 and 4.6. Once again, for this material, no significant differences are obtained between the two different preparation protocols.

The linear response of the pure material corresponds to that of a viscous liquid ( $G$ " is proportional to the frequency and G' smaller than G" for the entire frequency range studied). The addition of nanoclays leads to the expected increase in $\mathrm{G}^{\prime \prime}$, but the response remains proportional to the frequency. The data of $\mathrm{G}^{\prime}$ also shows that no good dispersion is obtained in the polyol component with this Recticel formulation. Even a worse dispersion than for Recticel low viscosity formulation is observed for both dispersion techniques, as any remainder of the existence of a plateau at low frequencies is observed.

\subsubsection{Discussion}

The data obtained from the previous measurements can be plotted as in figure 4.7 , where the modulus of the complex viscosity $\eta^{*}$ is plotted as a function of the complex modulus $\mathrm{G}^{*}$ (Winter-plot, see section 3.2.1). This representation enables to make a comparison between the two preparation techniques and between the three different formulations. A variation in the curve slope implies a better dispersion, so a higher variation in the slope implies a much better dispersion ${ }^{3}$. This is a consequence of the Cox and Merz rule ${ }^{4}$, an empirical relationship between steady state shear viscosity (at a given shear rate) and the dynamic viscosity (at the same frequency). This rule can be used in an analytical sense, as a measure of the materials microstructure from the degree to which they follow to the rule. In order to make a better comparative between the three formulations, only the data for a $3 \% \mathrm{wt}$. nanoclays are represented in the Figure 4.7.

For the BASF formulation, a difference in preparation technique is visible, with a rise of nearly two orders of magnitude in the modulus of the complex viscosity as compared to the pure polyol material between the material prepared with high shear mixing and the one prepared with ultrasonication. For both Recticel formulations, almost no difference in preparation technique can be observed in Fig. 4.7. Compared to the BASF formulation, the rise in the modulus of the complex viscosity is modest.

The dispersion state of nanoclays is highly dependent on the preparation protocol for the BASF-formulation. Ultrasonication proves to be a better technique to disperse nanoclays in the case of the BASF formulation. However, when compared to literature data (GalindoRosales et al. ${ }^{2}$ showed how the rheological signature of the particles is especially visible in the 
elastic properties at low frequencies, see Fig. 3.8), we should expect a larger increase in the dynamic mechanical properties G' and G" for the concentration of nanoclays under study. This is an indication that the nanoclays are not exfoliated during the dispersion and that still native or intercalated tactoids exists in the sample (see results of SAXS experiments (section 4.3.1.3)).

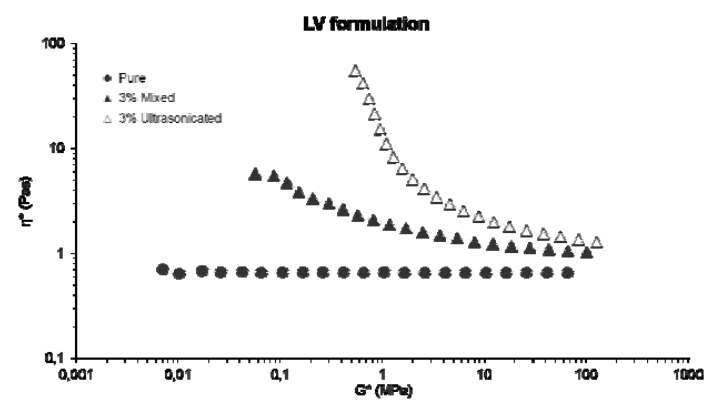

(a)

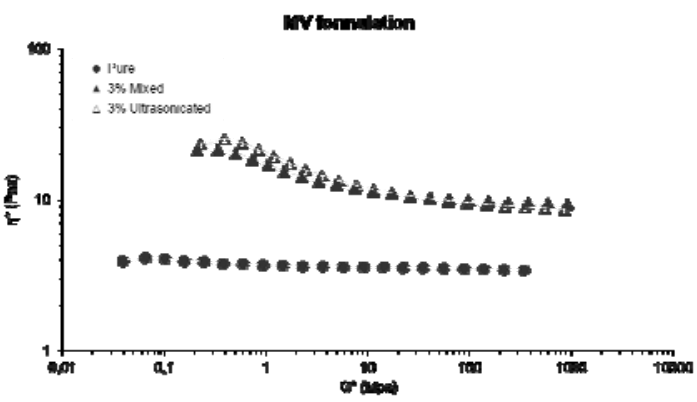

(b)

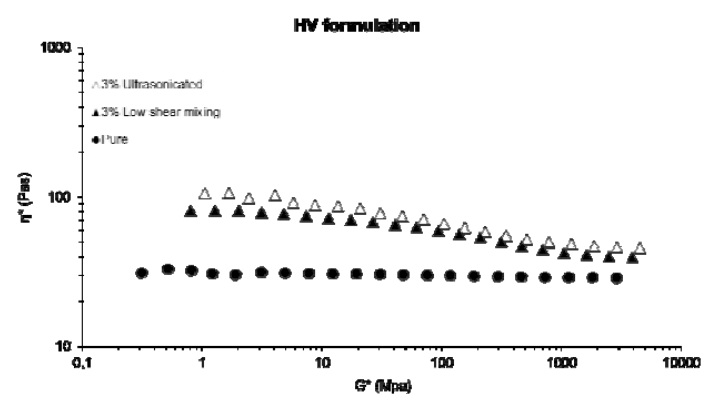

(c)

FIGURE 4.7: Modulus of complex viscosity $\eta^{*}$ versus modulus of the complex modulus $G *$. Data obtained from a frequency sweep at $23^{\circ} \mathrm{C}$, preshear of $1 \mathrm{~s}^{-1}$ for 5 minutes followed by an equilibration period of 25 minutes: (a) BASF formulation (b) Recticel low viscosity formulation (c) Recticel high viscosity formulation.

The second observation is that, though the nanoclays indeed give rise to an increase G' and G" for the Recticel formulation, the increase is significantly lower than for the BASF formulation. As the physical parameters (concentration, preparation protocol, measurement protocol,...) are the same, the difference should be due to a different chemical nature of both formulations and as consequence a different interaction between the polyol component and the nanoclays and/or to the different viscosities of each formulation. 


\subsection{Foams characterization}

After the rheological study, the BASF formulation (LV) was selected to produce foamed materials because its polyol component was the most sensitive to the different dispersion techniques used. With this formulation, different foams were produced. The two previously studied dispersion techniques were used, and another new one was added. Hand mixing technique (HM, see section 3.1), with an expected lower dispersion quality than the previous ones $^{2}$, was also employed trying to widen the spectra of the dispersion qualities. Nanoclays concentration was set in $3 \% \mathrm{wt}$ for all the produced foams.

\subsubsection{Structural characterization}

\subsubsection{Density}

Density results are shown in table 4.1. The nanofillers inclusion produced a small density reduction only in the low shear mixing technique foam. However, in general terms the macroscopic density tends to have a slight increase when nanoclays are added. The reason for this slight growth could be connected with higher viscosity of the initial blend when clays are infused $^{5,6}$ (see previous section), combined with the fact that nanofillers density (Cloisite 30B $1980 \mathrm{Kg} / \mathrm{m3}$ ) are higher than that of the reference foam (around $50 \mathrm{~kg} / \mathrm{m}^{3}$ ).

TABLE 4.1. Density of the manufactured materials

\begin{tabular}{ccc}
\hline Material & $\begin{array}{c}\text { Density } \\
\left(\mathbf{k g} / \mathbf{m}^{3}\right)\end{array}$ & $\begin{array}{c}\text { Standard } \\
\text { deviation } \\
\left(\mathbf{k g} / \mathbf{m}^{3}\right)\end{array}$ \\
\hline LV Pure & 53.37 & 0.92 \\
\hline LV 3\% HM & 56.77 & 6.75 \\
\hline LV 3\% LS & 51.64 & 0.39 \\
\hline LV 3\% US & 54.63 & 1.9 \\
\hline
\end{tabular}

Anyway, these density changes are small and with a high dispersion (specially for the foams produced by hand mixing), as polyurethane foam density is very sensitive to small changes in environmental conditions, like moisture and temperature, and even to small changes in mixing times ${ }^{7}$. 
Chapter 4: Influence Of The Formulation And Dispersion Technique Employed

\subsubsection{Cellular structure}

SEM micrographs of the different samples can be observed in figure 4.8. Images show that the addition of nanofillers implies a reduction of cell size, as is shown in the cell size distribution histograms (Fig. 4.9). This result was observed independently from the dispersion technique employed. For the pure material, the cells have sizes in the range between 400 and $500 \mu \mathrm{m}$, whereas in the case of nanoclays this range starts at lower sizes and is wider. This different dispersion of the cell sizes can be also observed in the SEM images; in the pure material the cell size is more homogeneous than in the materials infused with nanoclays.

a)

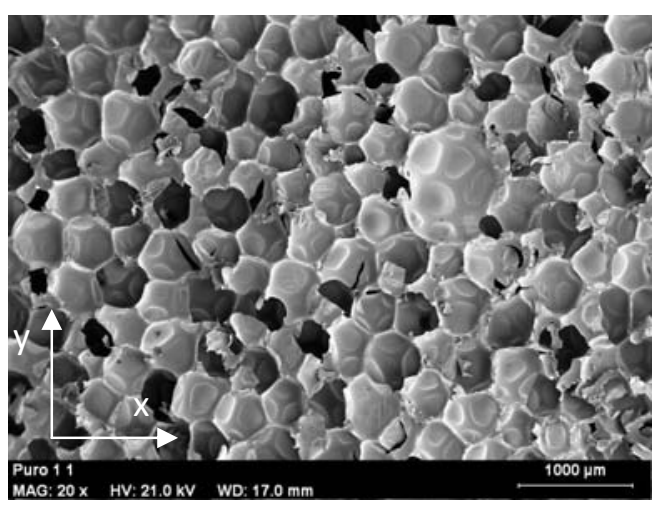

c)

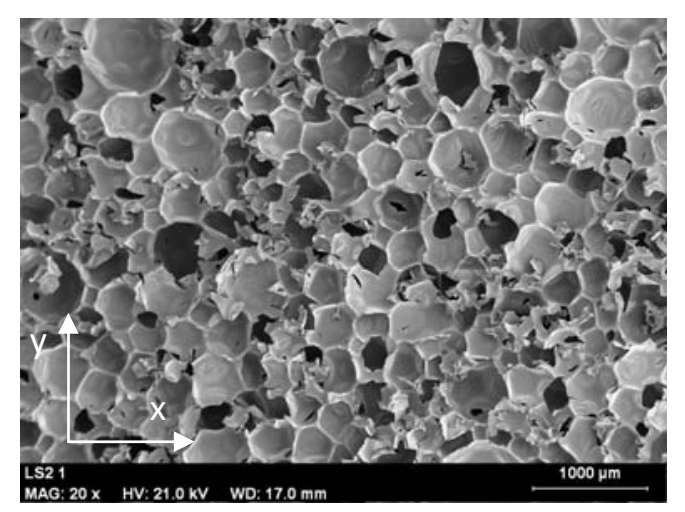

b)

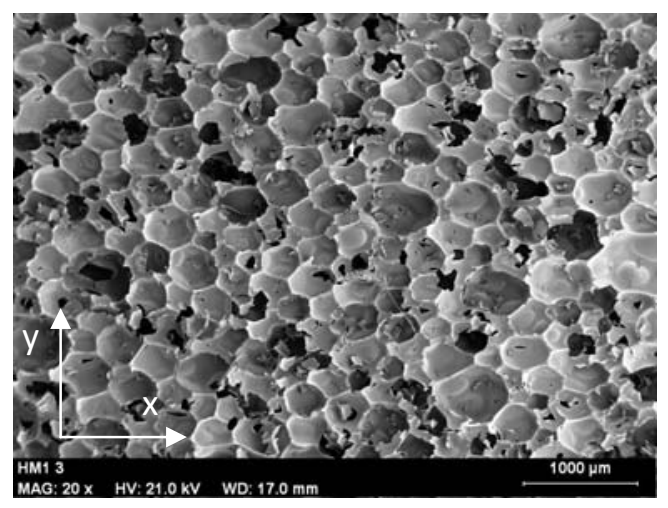

d)

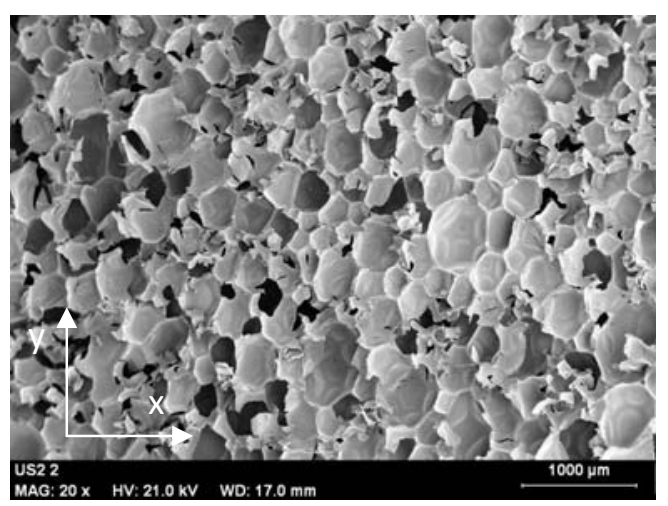

FIGURE 4.8. SEM images: (a) Pure material, (b) 3wt\% nanoclays, dispersion technique: HM, (c) 3wt\% nanoclays, dispersion technique: LS, (d) 3wt\% nanoclays, dispersion technique: US.

Analysis of SEM images also provides quantitative information, which can be observed in Figure 4.9 and in Table 4.2. Figure 4.9 shows the cell size distributions of the different materials in a plane containing the growing direction ( $y$ direction). It is possible to corroborate the qualitative observations over the SEM images previously mentioned. The inclusion of nanoclays produces a reduction of the average cell sizes. But the study of these histograms can 
give some extra information. Gaussian fitting of the data allows observing a wider distribution when the clays are added.
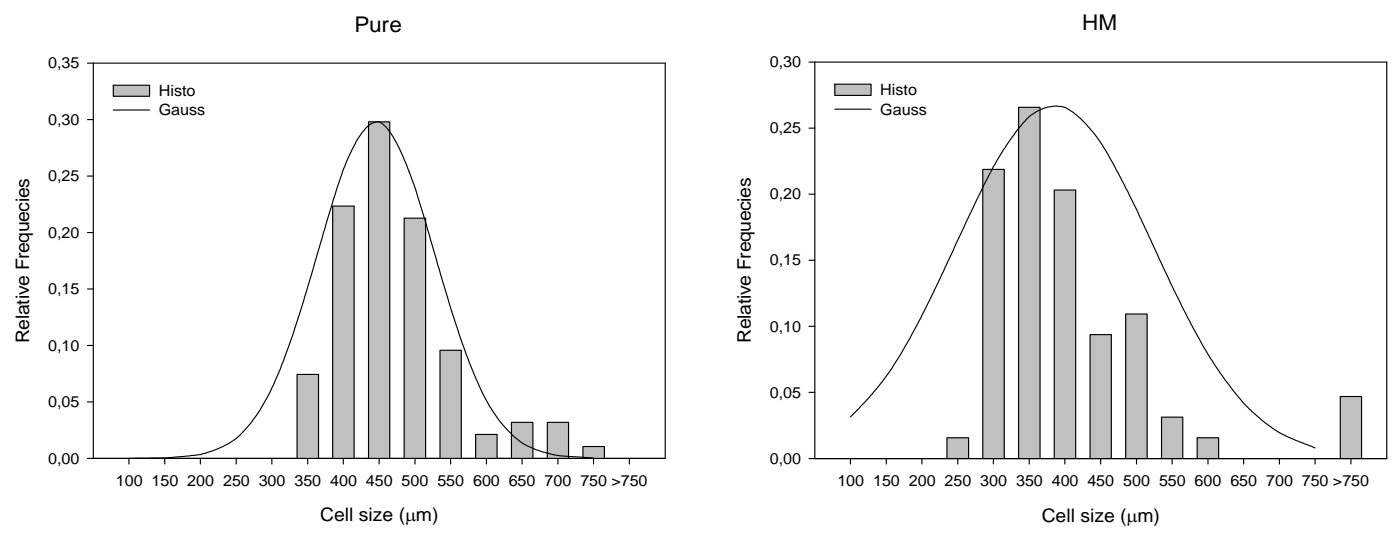

LS

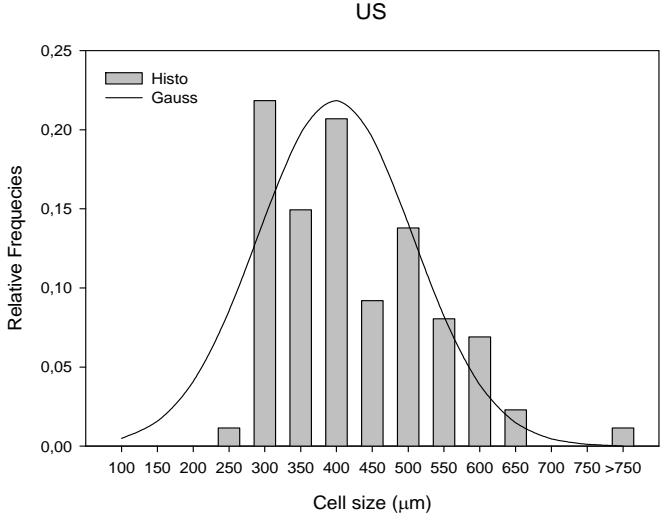

FIGURE 4.9. Cell size histograms: Pure material and 3wt\% nanoclays for the three different dispersion techniques.

Table 4.2 shows numerical values of the cellular structure characterisation. A cell size reduction between 9 and $12 \%$ for different samples is observed, as consequence a slight increase of cell density is detected. No significant difference in the anisotropy of the cells is observed between pure material and material with nanoclays, where $y$ is referred to the growing direction. Besides the reduction of the cell size, the inclusion of nanoclays implies a higher dispersion of the cell sizes values, as is shown in the NSD values. Asymmetry coefficient is reduced when clays are added indicating a more symmetric distribution for the foamed nanocomposites. Open cell percentage presents variations with the inclusion of nanoclays, but in any case more than $5 \%$ with respect to pure material. 
Chapter 4: Influence Of The Formulation And Dispersion Technique Employed

TABLE 4.2. Cellular data of the manufactured materials

\begin{tabular}{|c|c|c|c|c|c|c|c|}
\hline Material & $\begin{array}{l}\text { Average cell } \\
\text { size }(\mu \mathrm{m})\end{array}$ & $\begin{array}{c}\text { Anisotropy } \\
R(y / x)\end{array}$ & $\begin{array}{l}\text { Asymmetry } \\
\text { coefficient } \\
\text { (AC) }\end{array}$ & NSD & $\begin{array}{l}\text { Cell density } \\
\qquad \text { (no } \\
\text { cells } / \mathrm{m}^{3} \text { ) }\end{array}$ & $\begin{array}{l}\text { Open } \\
\text { cell } \\
(\%)\end{array}$ & $\begin{array}{l}\text { \% reduction of } \\
\text { cell size with } \\
\text { respect to the } \\
\text { pure material }\end{array}$ \\
\hline LV Pure & 440 & 1.20 & 2.073 & 0,191 & $2,15 \cdot 10^{10}$ & 8.0 & \\
\hline LV 3\% HM & 396 & 1.25 & 1.769 & 0,321 & $3,06 \cdot 10^{10}$ & 5.6 & 9.9 \\
\hline LV $3 \%$ LS & 388 & 1.10 & 1.018 & 0,274 & $2,85 \cdot 10^{10}$ & 3.1 & 11.7 \\
\hline LV $3 \%$ US & 396 & 1.36 & 1.343 & 0,292 & $2,97 \cdot 10^{10}$ & 9.7 & 9.7 \\
\hline
\end{tabular}

The reduction of the cell size without a remarkable density change could be a consequence of two simultaneous effects: filler could act as nucleating agent for the cells, and also as stabilizer of the cell walls. Nucleating effect, which can be explained by the classical nucleation theory ${ }^{8,9}$, is the consequence of a reduction of surface energy by the inclusion of particles that allows the creation of additional cells ${ }^{10}$. The effect of nanoclays as stabilizer of the cell walls could reduce coalescence, promoting a higher cell density and lower cell size. Anyway, recent studies have shown that principal role of nanoclays in this system is as nucleating agent ${ }^{11}$.

Table 4.3 shows the cell size reduction in different polyurethane foams infused with different kinds of nanoparticles. The data have been obtained from previous works developed in CellMat laboratory and literature. As it can be observed, the cell size variation depends highly on the particle employed and its concentration. Moreover, the same kind of nanoparticle with different functionalization produces dramatically different changes in cell size. It can be seen in Harikrishnan et al. article ${ }^{14}$, where it was observed a $3 \%$ of increase in cell size in the case of pure nanoclays and a $58 \%$ of cell size reduction in the case of Cloisite $20 \mathrm{~A}$, for the same concentration of nanoclays. It is possible to observe in Table 4.3 the effect of the polyol type employed ${ }^{13}$, and how for the same nanoparticle and concentration the effect over the cell size can be completely different. 
TABLE 4.3. Polyurethane data from the literature. (-) means that cell size is reduced when the particles are added, $(+)$ means that cell size is increased when the particles are added.

\begin{tabular}{|c|c|c|c|}
\hline Material & Reference & Nanoparticle & $\begin{array}{c}\text { Cell size variation with respect } \\
\text { pure material (\%) }\end{array}$ \\
\hline PU + 1\% Sepiolite & $\begin{array}{c}\text { CellMat } \\
\text { Laboratory }\end{array}$ & Organomodified Sepiolite & -6.6 \\
\hline PU + 3\% Sepiolite & $\begin{array}{c}\text { CellMat } \\
\text { Laboratory }\end{array}$ & Organomodified Sepiolite & 10.7 \\
\hline PU $+5 \%$ nanoclays & (12) & MMT-OH (Cloisite 30B) & -23 \\
\hline PU $+5 \%$ nanoclays & $(12)$ & MMT-Tin (Cloisite 30B modified) & -19 \\
\hline PU $+2 \%$ nanoclays & (13) & Purified natural montmorillonite & $\begin{array}{l}\text { Polyether based: } 26 \\
\text { Polyether-polyester based: }-3\end{array}$ \\
\hline $\mathrm{PU}+2 \%$ nanoclays & (13) & $\begin{array}{l}\text { Benzyl-dimethyl-hydrogenated- } \\
\text { tallow ammonium- } \\
\text { salt-modified natural } \\
\text { montmorillonite }\end{array}$ & $\begin{array}{l}\text { Polyether based: } 19 \\
\text { Polyether-polyester based: -25 }\end{array}$ \\
\hline $\mathrm{PU}+2 \%$ nanoclays & (13) & $\begin{array}{l}\text { Alkyl-imidazolium salt natural } \\
\text { montmorillonite }\end{array}$ & $\begin{array}{l}\text { Polyether based: } 79 \\
\text { Polyether-polyester based: } 14\end{array}$ \\
\hline PU + 2\% nansilica & (13) & Silica nanopowder & $\begin{array}{l}\text { Polyether based: } 28 \\
\text { Polyether-polyester based: }-11\end{array}$ \\
\hline $\begin{array}{c}\text { PU }+2 \% \text { Titanium } \\
\text { dioxide }\end{array}$ & (13) & Titanium dioxide nanopowder & $\begin{array}{c}\text { Polyether based: }-14 \\
\text { Polyether-polyester based: }-20\end{array}$ \\
\hline $\mathrm{PU}+$ pure nanoclays & (14) & Natural montmorillonites & $\begin{array}{l}\text { 1\% Nanoclays: }-6 \\
\text { 2.3\% Nanoclays: } 3 \\
\text { 3.6\% Nanoclays: }-5\end{array}$ \\
\hline PU + Cloisite 25A & (14) & $\begin{array}{l}\text { hydrogenated tallow } \\
\text { alkylmethyl-(2- } \\
\text { ethylhexyl)ammonium salts } \\
\text { modified natural } \\
\text { montmorillonite }\end{array}$ & $\begin{array}{c}\text { 1\% Nanoclays: }-8 \\
\text { 2.3\% Nanoclays: }-52 \\
\text { 3.6\% Nanoclays: }-44\end{array}$ \\
\hline PU + Cloisite 20A & (14) & $\begin{array}{l}\text { dimethyl, dehydrogenated } \\
\text { tallow, quaternary ammonium } \\
\text { salts modified natural } \\
\text { montmorillonite }\end{array}$ & $\begin{array}{l}\text { 1\% Nanoclays: }-64 \\
2.3 \% \text { Nanoclays:-58 } \\
\text { 3.6\% Nanoclays: }-66\end{array}$ \\
\hline PU + Cloisite 93A & (14) & $\begin{array}{l}\text { methyl, dehydrogenated tallow } \\
\text { alkylammonium salts modified } \\
\text { natural montmorillonite }\end{array}$ & 1\% Nanoclays: -28 \\
\hline
\end{tabular}


The observed sensitivity to the different implied variables of the polyurethanenanoparticle systems confirms the high similitude between the different dispersion techniques employed in the present work: independently from the dispersion technique employed the cell size reduction is really similar in our case.

Table 4.2 also shows a cell density increase by the nanoclays addition. Similar data are observed for all dispersion techniques. To study this variation, the potential nucleant density in a heterogeneous nucleation system can be estimated $\mathrm{as}^{15}$ :

$$
\frac{\text { Nucleants }}{\mathrm{cm}^{3}}=\frac{w}{\rho_{N}} \frac{\rho_{\text {blend }}}{V_{P}}
$$

where $w$ is the weight fraction of the nanocparticle in the composite, $\rho_{N}$ is the density of the nanoclays, $\rho_{\text {blend }}$ is the density of the polymer blend and $V_{P}$ is the volume of the individual particle. This estimation, for an average nanoclay particle dimension of $1000 \times 1000 \times 1 \mathrm{~nm}^{2}{ }^{16}$, and for 3 wt\% nanoclays, gives a potential nucleant density of $1.52 \times 10^{16} \mathrm{~m}^{-3}$ much higher than the cell density values measured and included in table 4.2. The nucleation efficiency, defined by the ratio of the measured cell density to the potential nucleant density, is close to $1.98 \times 10^{-}$

${ }^{6} \%$ for all the dispersion techniques, a low value which could indicate a poor activity as nucleating agent and/or very poor exfoliation. However, if we consider dispersion as a critical parameter, differences over the samples prepared using different dispersion techniques should be expected, and this is not the case. Although the obtained value is really low, similar values has been found in a previous study performed in PS by Shen et $\mathrm{al}^{10}$, the potential nucleant density of nanoclays (modified with 2-methacryloyloxyethyhexadecyldimethyl ammonium bromide, MHAB) in $5 \mathrm{wt} \%$ had a value of $7.37 \times 10^{-4} \%$, and TEM images in this study showed a good exfoliation. The results obtained indicate that independently of the degree of nanoclays dispersion the effect on the cellular structure is almost the same.

\subsubsection{SAXS}

SAXS patterns present in Fig. 4.10 allow obtaining information about the intercalation/exfoliation of clays in the different systems for a fixed $3 w t \%$ concentration. In this graph, it is possible to observe the results for the pure material and the pure nanoclays. 
For the pure nanoclays it is detected the characteristic diffraction peak due to the lamellar structure of the nanoclays, for a $2 \theta$ value close to 4.7 degrees. According to Bragg equation presented in Chapter 3 (Eq. 22), and taking into account that experiments were performed using a X-ray tube with $\lambda=1.5406 \AA$, it is possible to obtain a value for the inter-lamellar space in Cloisite 30B of $18.8 \AA$, close to the $18.5 \AA$ data supplied by Southern Clay Products, Inc. (See table 3.2)

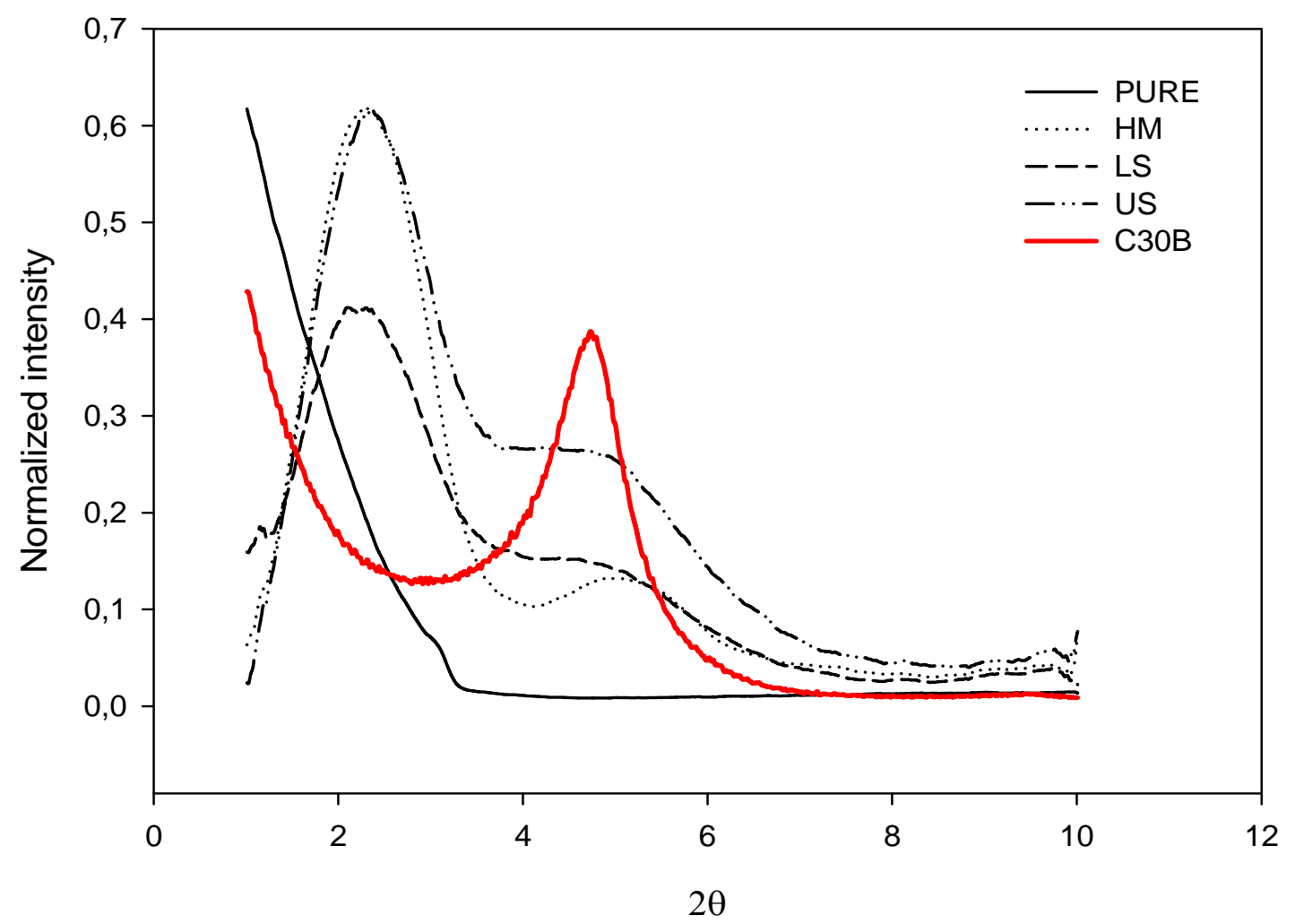

FIGURE 4.10. SAXS patterns for polyurethane foams prepared with different dispersion techniques and for pure Cloisite 30B nanoclays.

The results show a decrease of the same peak for the different dispersion techniques, and an increase in its width, together with the presence of a higher peak at around $2.2^{\circ}$. In the case of the hand mixing technique, a shifting to higher angles (that implies a decrease in the inter-lamellar space) has been observed. The increase in the width of the peak at $4.7^{\circ}$ and the presence of a new peal at $2.2^{\circ}$ confirms the intercalation of the nanoclays, even with a nonoptimal dispersion technique. The intercalation is related with a good interaction between the polymeric matrix and nanoparticles ${ }^{17}$, promoted mainly by a compatible organomodification with the polyurethane matrix. So, although intercalation is not probably reached during 
nanoclays dispersion in polyol as it can be concluded from the rheological study, isocyanate addition and polymerization reaction lead to a nanoclays intercalation even in the worst of the dispersion cases. On the other hand, the results clearly show that the clays are not exfoliated by any of the mixing processes used.

\subsubsection{Macroscopic characterization}

\subsubsection{Dynamic Mechanical Analysis}

Fig. 4.11 (a) shows the evolution of the storage modulus $\left(E^{\prime}\right)$ with the temperature, for pure material and nanoclays-filled samples. E' decreases slowly and progressively with the temperature for all samples below $80^{\circ} \mathrm{C}$. Then it shows a very strong decay between 80 and $180^{\circ} \mathrm{C}$, correlated with the transition from the glassy to the rubbery state. At temperatures below the glass transition, a slight increase of $E^{\prime}$ value is observed by the inclusion of nanoclays for the HM and the LS samples, for the US sample there is a slight decrease of $\mathrm{E}^{\prime}$. For a better understanding of the nanoclays effect and the different mixing techniques, the relative storage modulus (the quotient of the values for the different dispersion techniques with respect to the pure material) is plotted as a function of temperature in Fig. 4.11(b). In the glassy region, nanoclays produce a small (and none for US mixing technique) rise in $E^{\prime}$. In the glass transition region, the values increase between $200 \%$ and almost $400 \%$ near 160 ㅇ․ This increase is observed for all dispersion techniques. This improvement in storage modulus suggests a favourable interfacial interaction between the nanofillers and the polyurethane matrix ${ }^{18,19}$. In particular, the mobility of the polymer molecule chains near the glass transition temperature $\left(T_{\mathrm{g}}\right)$ is markedly restricted, giving rise to an abrupt increase in storage modulus in this temperature region.

As expected in the glass transition region, energy dissipation increases greatly as the loss factor $(\tan \delta)$ tends to a maximum while the temperature at the maximum in this curve is considered the glass transition temperature $\left(T_{\mathrm{g}}\right)$ associated with the $\alpha$ relaxation of the polyurethane foams nanocomposites. Both $T_{\mathrm{g}}$ and $\tan \delta$ are connected with the mobility of polymer molecule chain segments. As presented in Fig. 4.12, the apparent $T_{\mathrm{g}}$ and $\tan \delta$ of pure polyurethane foam are $157{ }^{\circ} \mathrm{C}$ and 0.60 , while the $T_{g}$ shifts to 160,164 and $167^{\circ} \mathrm{C}$ for LS, HM and US nanocomposites and $\tan \delta$ is reduced to $0.44,0.42$ and 0.42 , respectively.

(a) 


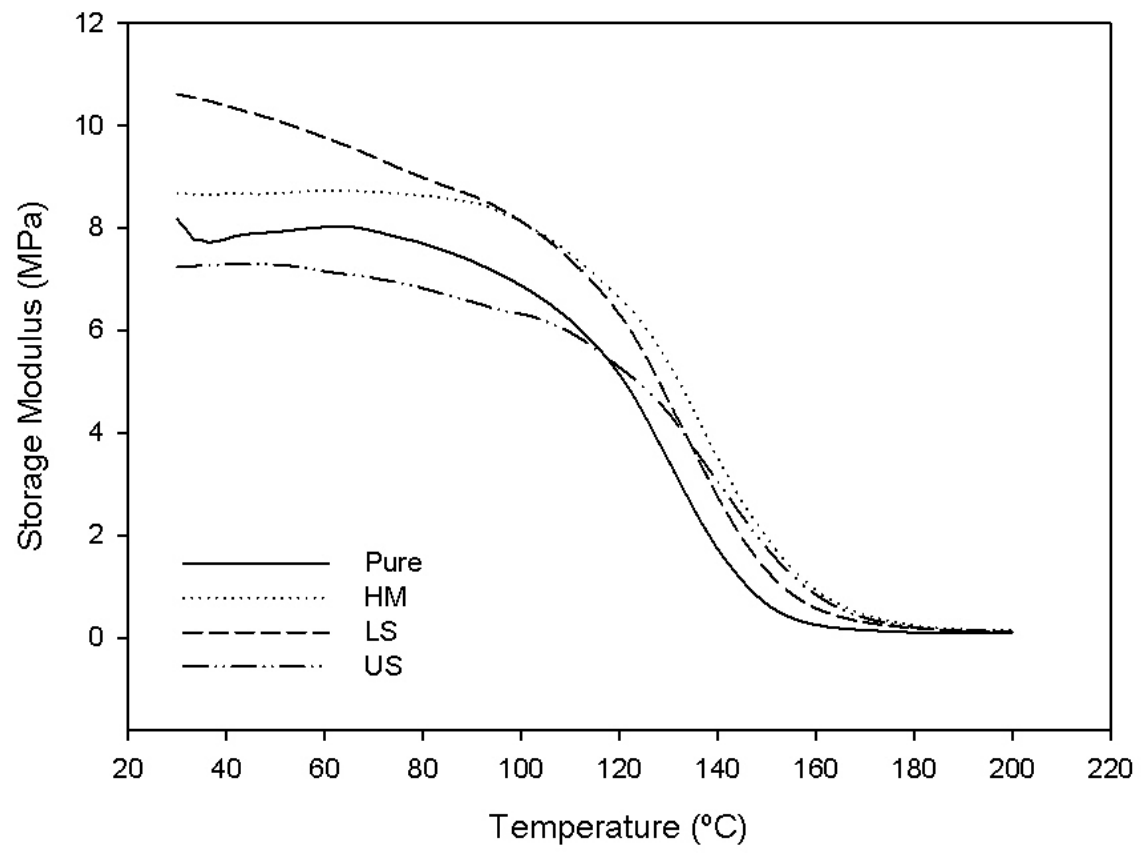

(b)

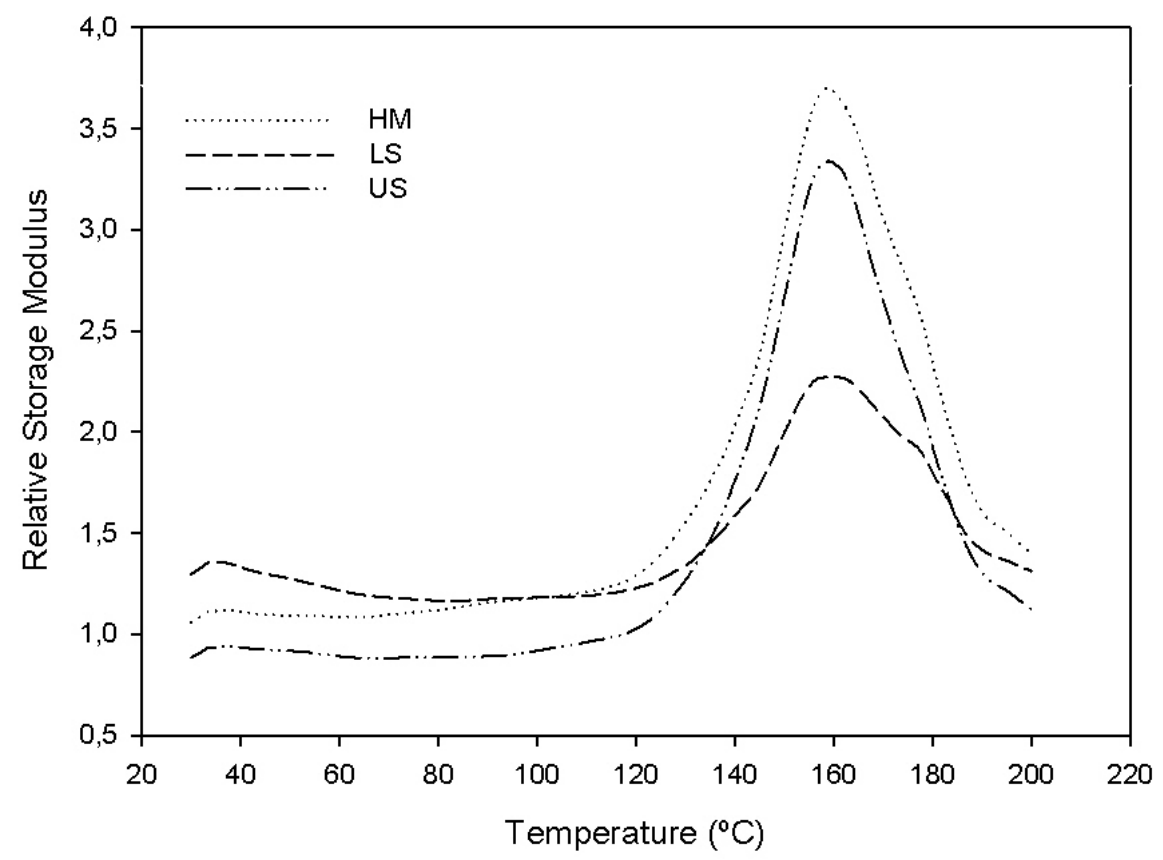

FIGURE 4.11. Temperature dependence of storage modulus (a) and relative storage modulus (b).

The value of $\tan \delta$ at the peak is reduced by a $28 \%$, a value much higher than the $3 \%$ by weight of filler used. Therefore the result cannot be understood using the mixing's rule. 
Nanoclays inclusion produced a clear increase in $T_{\mathrm{g}}$ and a clear decrease in $\tan \delta$, demonstrating the stiffening effect of these nanofillers, i.e. the presence of nanoclays highly impedes the polymer chain mobility via strong interfacial interactions and acts as a 'physical crosslink' during the glass transition ${ }^{20,21}$, which improves the heat resistance of the nanocomposites. Due to the high interfacial interaction between the polyurethane matrix with a two-dimensional geometrical morphology, and its clear effects on the variation (respect to materials with conventional aspect ratio) of the $T_{g}$ and $\tan \delta$ in previous studies ${ }^{22}$ (where the measured values for $T_{g}$ and $\tan \delta$ of pristine polyurethane rigid foam were $185^{\circ} \mathrm{C}$ and 0.6 , while the $T_{g}$ shifts to 201 and $199{ }^{\circ} \mathrm{C}$ for graphene nanosheets and carbon nanotubes nanocomposites and $\tan \delta$ shifts to 0.4 and 0.5 ), it is possible to conclude that a similar grade of interaction between the particles and the matrix is reached in the present study.

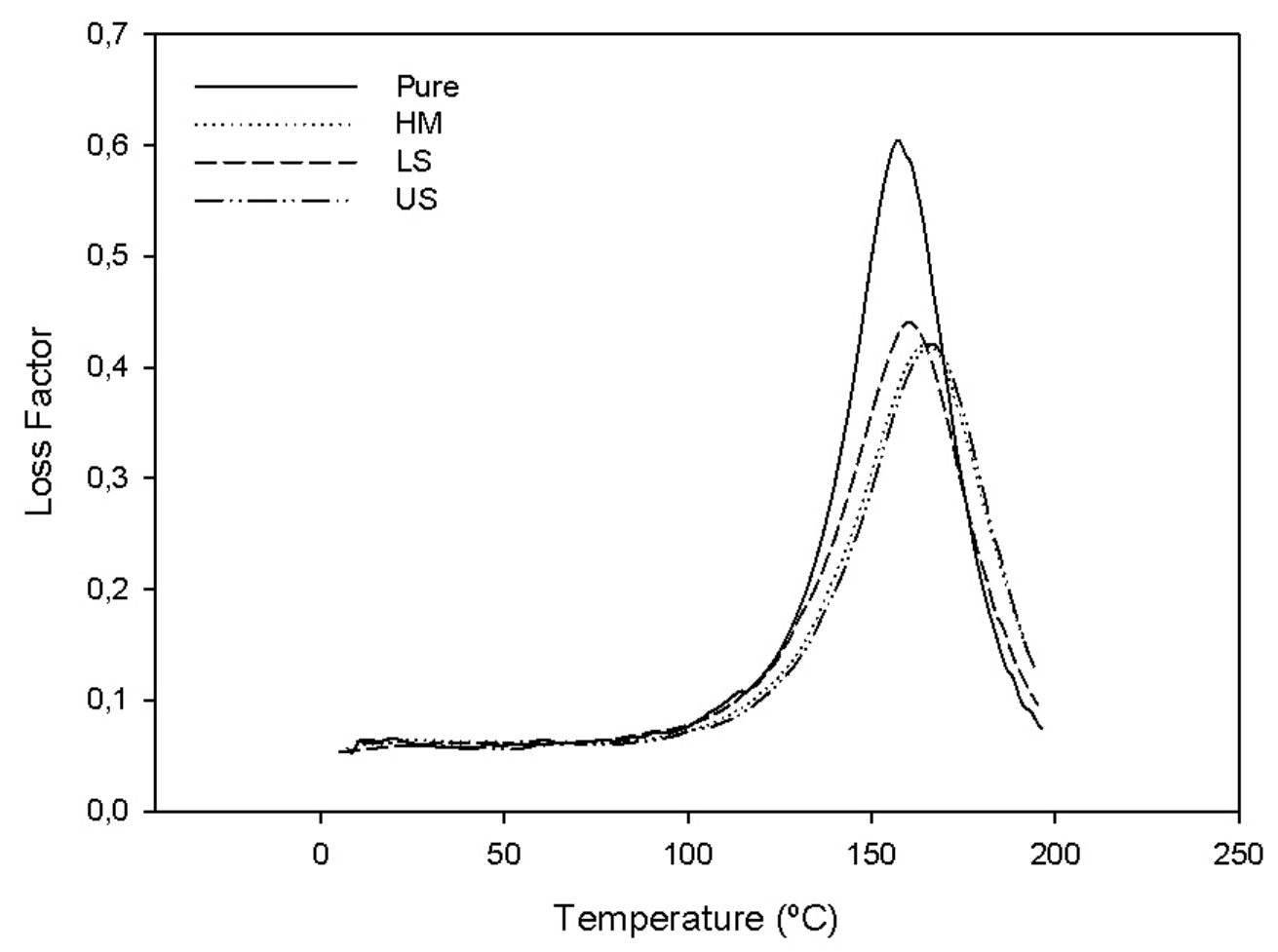

FIGURE 4.12. Temperature dependence of the loss factor $(\tan \delta)$.

\subsubsection{Mechanical properties in compression and shear}

Figure 4.13 shows an example of the compression experiments, where different slopes in the linear elastic region and collapse stresses can be observed for the different materials (pure 
material, and foamed nanocomposites with $3 \mathrm{wt} \%$ of clays dispersed using different methods). Final results (obtained from the stress-strain curve using the methods explained in section 3.2.3) are summarized in table 5.

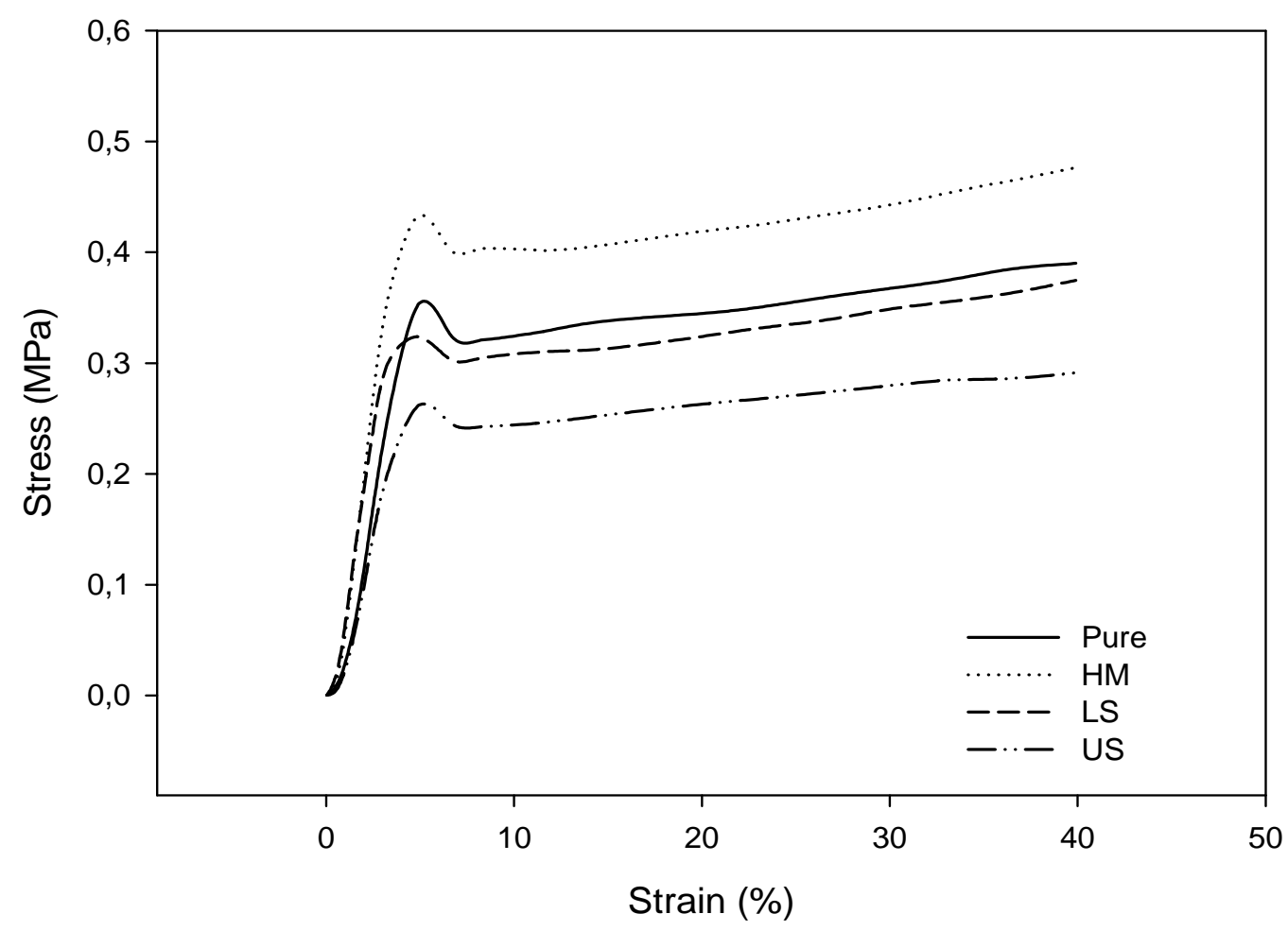

FIGURE 4.13. Examples of the stress-strain curves for the different materials

It is possible to detect a slight improvement of the Elastic Modulus of the foams with the inclusion of nanoclays, for all dispersion techniques, without large differences between them. Collapse strength also shows a small increase with the addition of the nanofillers for the handmixing technique (with a large dispersion), and the same value or even a decrease for the ultrasonication and the low-shear mixing technique, respectively.

Taking into account that fillers addition has produced some density changes, the previous comparisons are not precise enough as long as foams with different densities are compared. Material produced with HM technique requires special attention: it presented (table 4.1) a high standard deviation for the density measurements, and consequently it also presents a high deviation for the mechanical properties measured. 
Chapter 4: Influence Of The Formulation And Dispersion Technique Employed

TABLE 3. Compressive mechanical properties of the manufactured materials

\begin{tabular}{ccccc}
\hline Material & E (MPa) & $\begin{array}{c}\text { Standard } \\
\text { deviation } \\
\text { (MPa) }\end{array}$ & $\begin{array}{c}\text { Collapse } \\
\text { Strength (MPa) }\end{array}$ & $\begin{array}{c}\text { Standard } \\
\text { deviation } \\
\text { (MPa) }\end{array}$ \\
\hline LV Pure & 11.09 & 0.23 & 0.34 & 0.009 \\
\hline LV 3\% HM & 13.84 & 1.93 & 0.37 & 0.081 \\
\hline LV 3\% LS & 11.88 & 0.54 & 0.32 & 0.001 \\
\hline LV 3\% US & 12.39 & 1.38 & 0.34 & 0.028 \\
\hline
\end{tabular}

In order to make a better comparison of the material properties the scaling law proposed by Gibson \& Ashby for cellular materials was used ${ }^{23}$

$$
\frac{P_{f}}{P_{s}}=C\left(\frac{\rho_{f}}{\rho_{s}}\right)^{n}
$$

In this equation, as it was presented previously in section $2.1 .3, P_{f}$ is the property of the foamed material, $P_{s}$ is the same property for the same solid material, and $C$ and $n$ are fitting constants, $C$ being usually close to 1 and $n$ depending on the cellular structure and typically close to 2 for low density foams ${ }^{23}$ and properties such as the Elastic Modulus and Collapse Strength. Therefore, values of Elastic Modulus and collapse strength were normalized by the square of the density allowing a better comparison between the properties of materials with different densities (Figure 4.14 and Figure 4.15).

A small increase with the addition of nanoclays was observed for the relative Elastic Modulus ( $9 \%$ for HM technique, 14\% for LS technique and $7 \%$ for US tehonique), but this increase was not correlated with improvements in the dispersion quality. Instead of this, for the ultrasonication dispersion, which is the most optimal technique of dispersion (see section 4.2.1), the lowest improvement in the mechanical properties was obtained. Similar results were observed for both hand mixing and low shear dispersion techniques. 


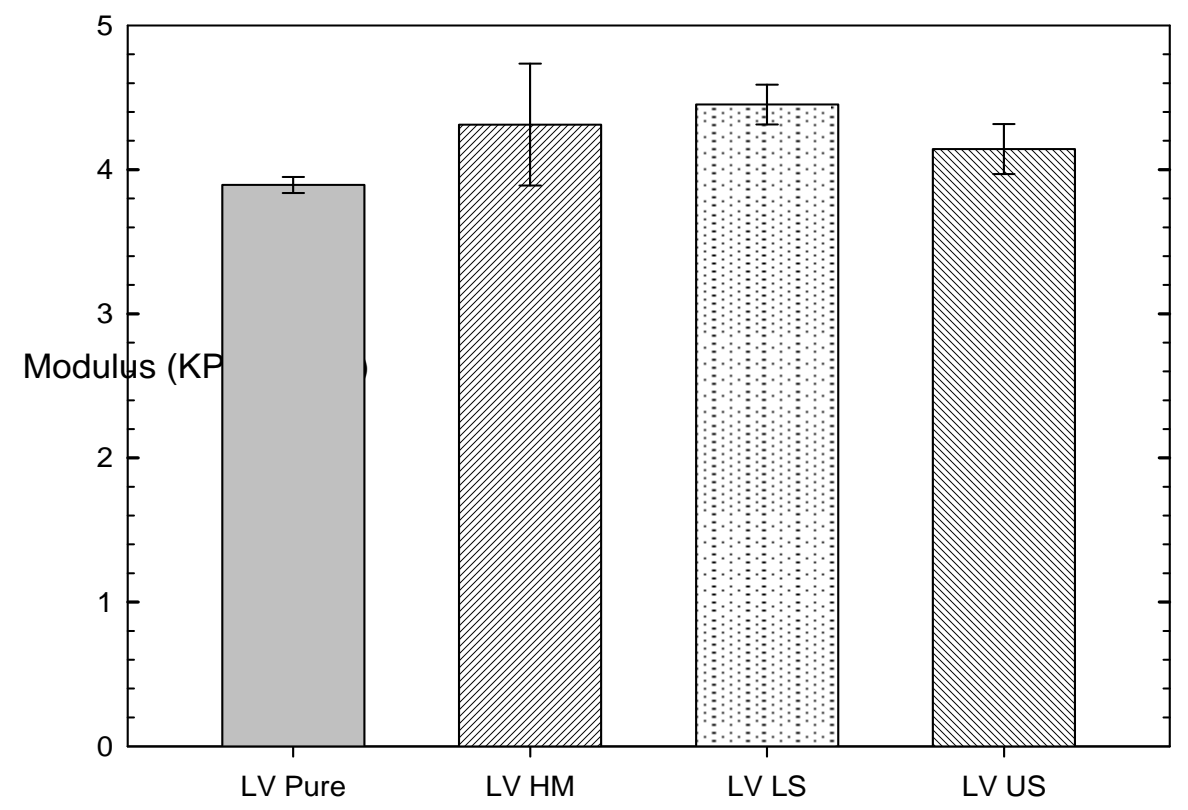

FIGURE 4.14 Relative Elastic Modulus, $\left(E / \rho^{2}\right)$ for materials produced using different dispersion techniques.

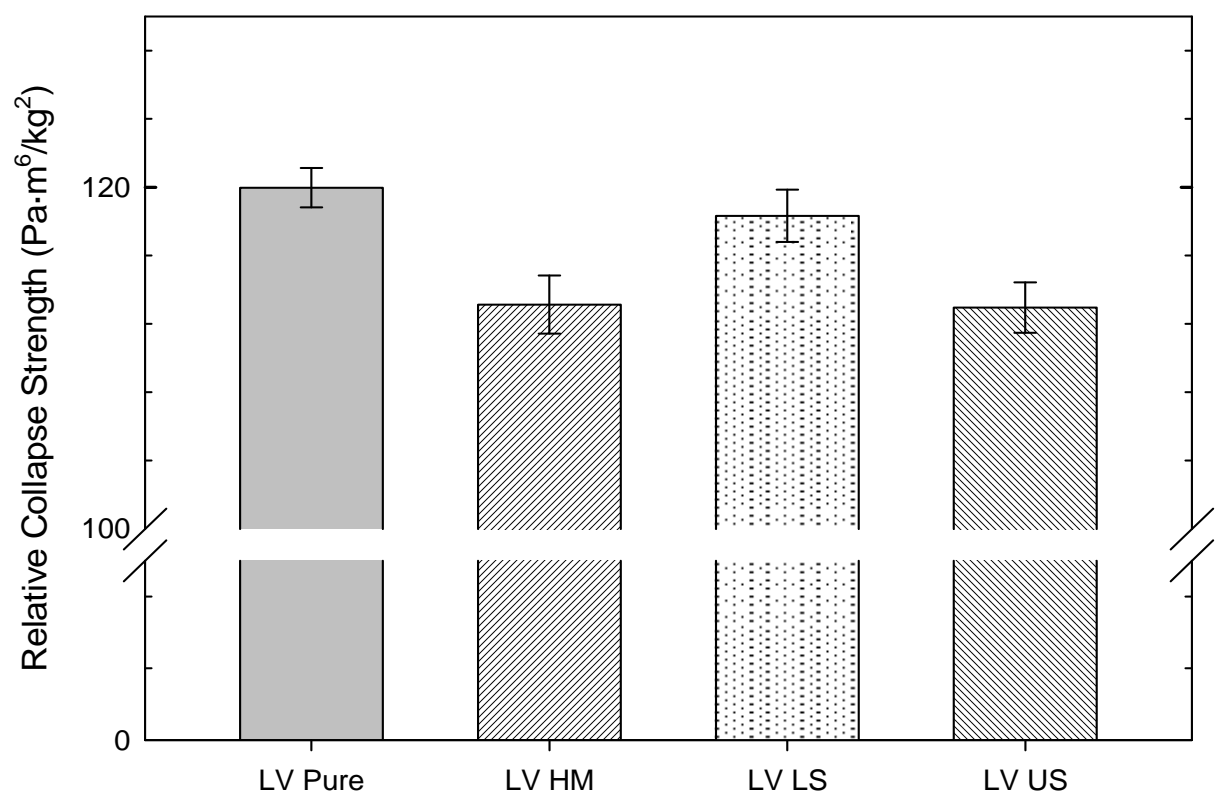

FIGURE 4.15. Relative Collapse Strength $\left(\sigma_{c} / \rho^{2}\right)$ for materials produced using different dispersion techniques. 
Other factor that must be taken into account is the anisotropy in the cellular structure, concretely the anisotropy ratio (R) defined in Chapter 2 (section 2.1.2). This cellular property has a clear effect over the final mechanical properties ${ }^{23}$, as it is shown in Eq. 3.

$$
E_{y}=C E_{S}\left(\rho / \rho_{S}\right)^{2} R
$$

In this equation $E_{y}$ represents the Elastic Modulus measured in the $y$ direction, $R$ is the anisotropy ratio (Table 4.2), $E_{S}$ is the modulus of the solid phase, $C$ is a constant with values close to one.

In order to eliminate the possible influence of the different anisotropies in the results, the values of the relative modulus $E / \rho^{2}$ were divided by the anisotropy ratio. Figures 4.16 and 4.17 show the results of this new normalization.

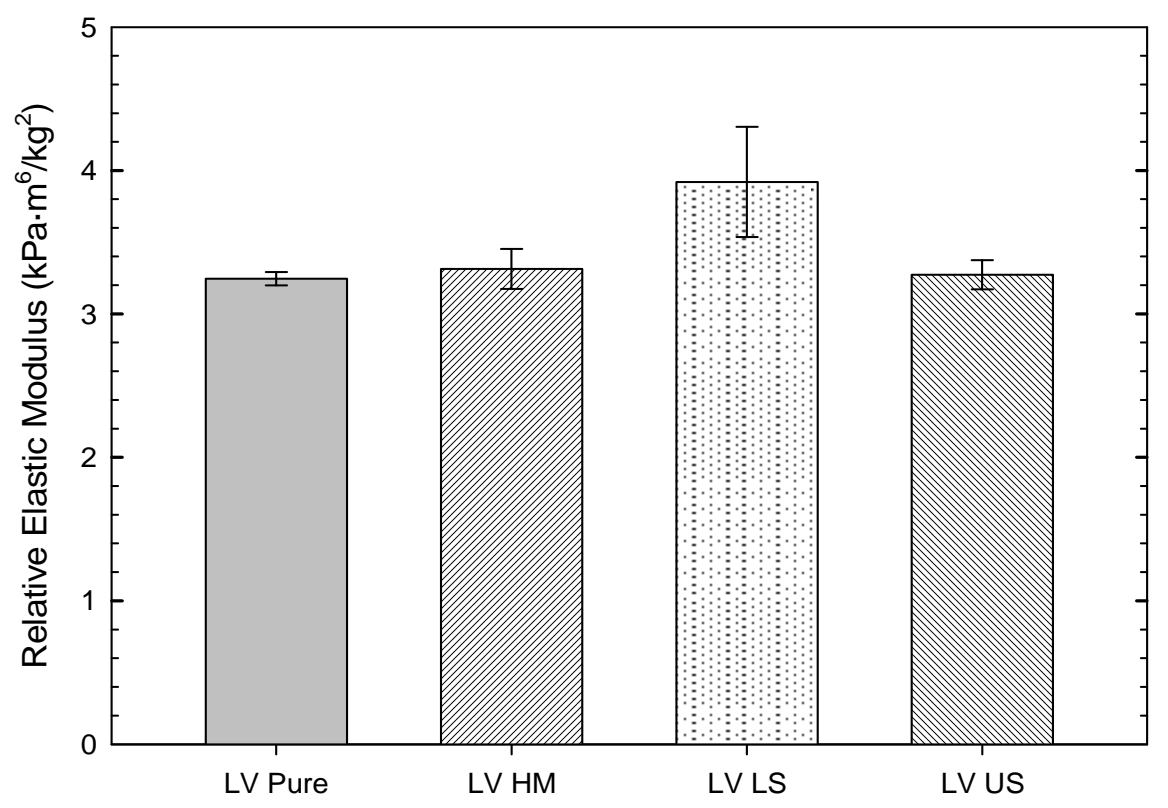

FIGURE 4.16 Relative Elastic Modulus to density and anisotropy $\left(E / C \cdot \rho^{2}\right)$, for materials produced using different dispersion techniques

The obtained results and trends observed are similar to the ones seen in Figures 4.14 and 4.15 indicating that the reason for the different properties of the materials with different dispersions are not related with variations in the anisotropy ratio. 


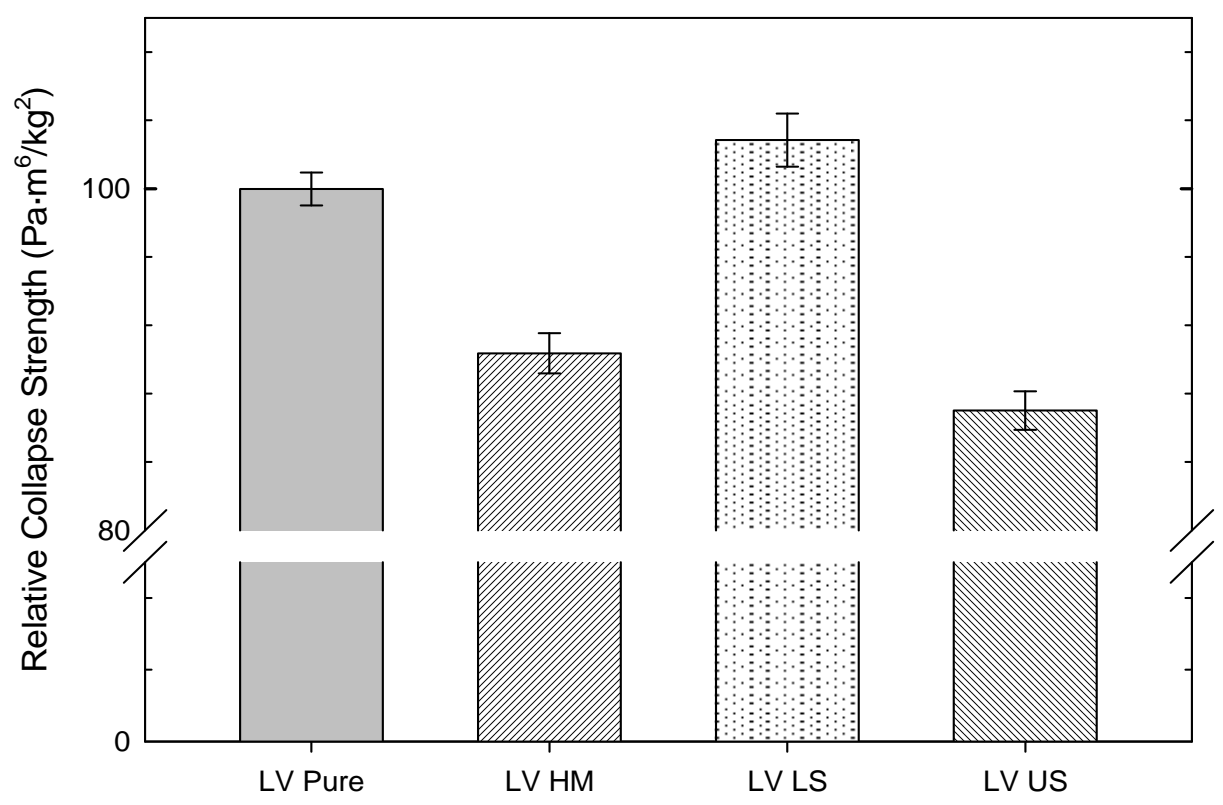

FIGURE 4.17 Relative Collapse Strength to density and anisotropy $\left(\sigma_{c} / C \cdot \rho^{2}\right)$, for materials produced using different dispersion techniques.

Average cell size and cell size distribution are other cell properties that can be related with changes in the mechanical properties. Anyway, previous works $\mathrm{s}^{24,25}$ have shown the small effect of these changes in properties such as the Elastic Modulus or the Compression Strength. Furthermore, an increase in the dispersion of the cell sizes could have a negative effect in the mechanical properties, as it was commented in the state of the art chapter, section 2.1.2. Therefore the slight increase in the elastic modulus of the materials containing clays cannot be related with the increase in the dispersion of cell sizes presented by the clays addition.

A reduction of the relative collapse strength was obtained with the addition of nanoclays for all the dispersion techniques. For this property, the lowest reduction was produced for the low-shear mixing technique, and for the other two techniques the results were very similar, with a reduction respect to pure material close to $6 \%$. An explanation for these results are included in the discussion section (section 4.3.3).

Shear modulus results for perpendicular plane to foaming direction (y-direction) and its perpendicular (x-direction) are summarized in Table 4. For $y$-direction a small increase of the modulus was observed again for the worst dispersion technique, while a small decrease was obtained for the more powerful dispersion techniques. 
Chapter 4: Influence Of The Formulation And Dispersion Technique Employed

TABLE 4. Shear properties of the manufactured materials

\begin{tabular}{ccccc}
\hline Material & $\begin{array}{c}\text { G y-direction } \\
\text { (MPa) }\end{array}$ & $\begin{array}{c}\text { Standard } \\
\text { deviation (MPa) }\end{array}$ & $\begin{array}{c}\text { G x-direction } \\
\text { (MPa) }\end{array}$ & $\begin{array}{c}\text { Standard } \\
\text { deviation (MPa) }\end{array}$ \\
LV Pure & 5.4 & 0.2 & 4.6 & 0.3 \\
LV 3\% HM & 5.7 & 0.3 & 4.6 & 0.1 \\
LV 3\% LS & 4.7 & 0.2 & 4.5 & 0.3 \\
LV 3\% US & 5.0 & 0.3 & 5.1 & 0.2 \\
\hline
\end{tabular}

For $\mathrm{x}$-direction similar results were obtained for all dispersion techniques, with exception for the US technique which presents a slight increase. Differences between $\mathrm{x}$ and $\mathrm{y}$-direction results could be related to the cellular anisotropy showed in table 4, as it is well known there is a dependency of the mechanical results with the cellular anisotropy ${ }^{23,26}$.

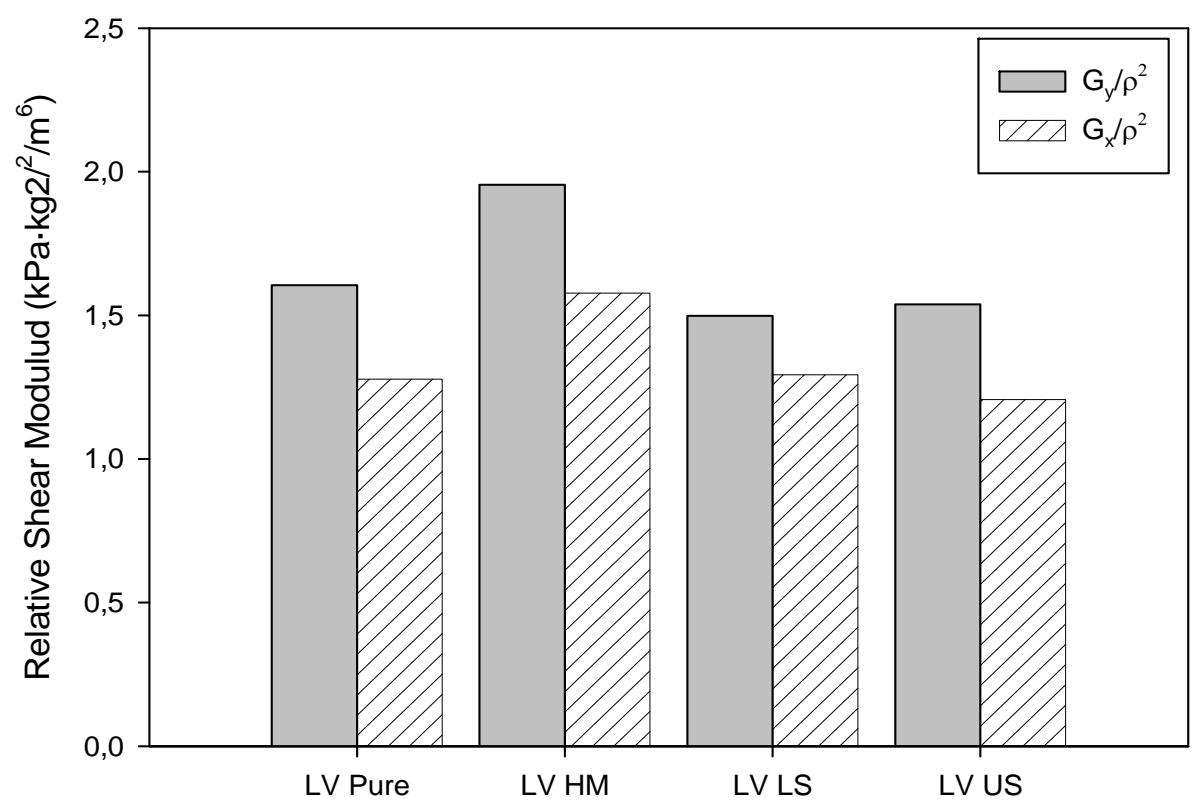

FIGURE 4.17. Shear modulus relative to the squared density. 
In order to have a better comparison of the material properties, it is necessary to employ the scaling law proposed by Gibson \& Ashby $^{23}$ for cellular materials previously used in the case of the compression properties. With the help of this relationship it is possible to reduce the influence of the material density in the final mechanical properties. Fig. 4.17 shows the shear properties relative to the square of density $\left(G / \rho^{2}\right)$. Figure 4.17 shows the reinforcement for the material produced with the hand mixing dispersion technique, while for the others techniques similar properties were observed.

The differences in the material properties detected in shear modulus for different planes of measurement can be analysed in more detail using the equations proposed by Gibson and Ashby $^{23}$. The shear modulus ratio in the two different planes is a fraction of the anisotropy ratio with a slight dependence given by equation 4 :

$$
\frac{G_{y}}{G_{x}}=\frac{2}{1+R}
$$

Where $G_{i}$ is the shear modulus measured in the plane defined by a vector in the $i$ direction and $\mathrm{R}$ is the anisotropy ratio of the cellular structure.

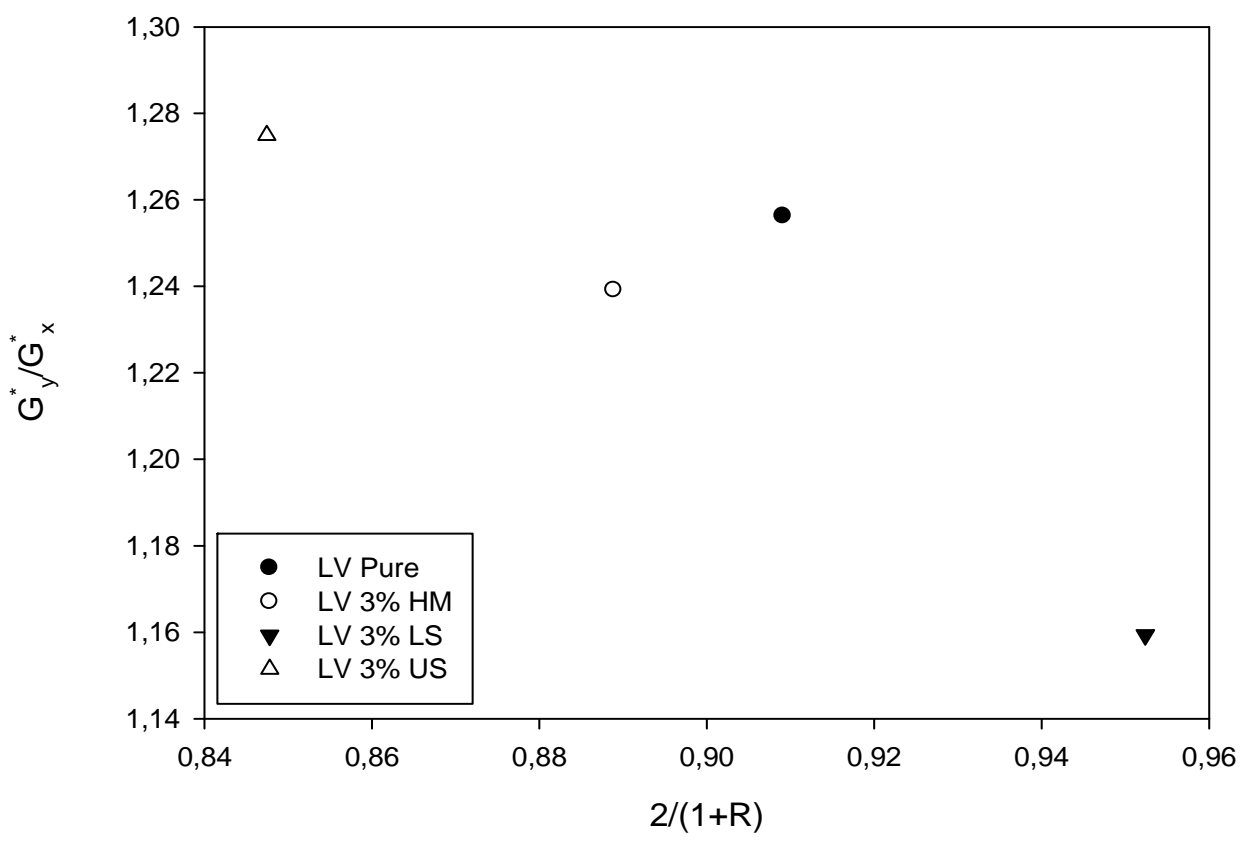

FIGURE 4.16.- Correlation between shear modulus and anisotropy, for the different dispersion techniques. 
As all the elements in Eq. 4 have been measured during the characterisation of the produced materials, it is possible to analyse if our results are correlated with this equation, as it is shown in Fig. 4.16. No clear correlation is observed, so other properties (as density dependence) beyond the anisotropy should to be taken into account.

Other calculations for the shear modulus can be made employing Eq. $5^{21}$; that relate the Elastic Modulus and the Shear Modulus.

$$
G_{i}=\frac{E_{i}}{2\left(1+v_{i}\right)}
$$

Where $\mathbf{G}_{\mathbf{i}}$ is the shear modulus in the plane perpendicular to the $\mathbf{i}$ direction, $\mathbf{E}_{\mathbf{i}}$ the elastic modulus in the $\mathbf{i}$ direction and $\mathbf{v}_{\mathbf{i}}$ is the Poisson's ratio relative to this direction, which is the negative ratio of the lateral to the axial $\operatorname{strain}^{23}$. With the previously obtained experimental data is possible to calculate the Poisson's ratio with Eq. 4 for the different dispersion techniques, and compare these results with the literature for polyurethane foams.

TABLE 5. Estimation of the Poisson's ratio for the different materials

\begin{tabular}{cc}
\hline Material & Poisson's ratio \\
\hline LV Pure & 0,026 \\
\hline LV 3\% HM & 0,214 \\
\hline LV 3\% LS & 0,263 \\
\hline LV 3\% US & 0,239 \\
\hline
\end{tabular}

Table 5 shows the calculation of the Poisson's ratio for the different dispersion techniques. It is possible to observe that for all these techniques its value is in the majority of the cases close to 1/3, a typical value for foams as it can be seen in Figure 4.18. 


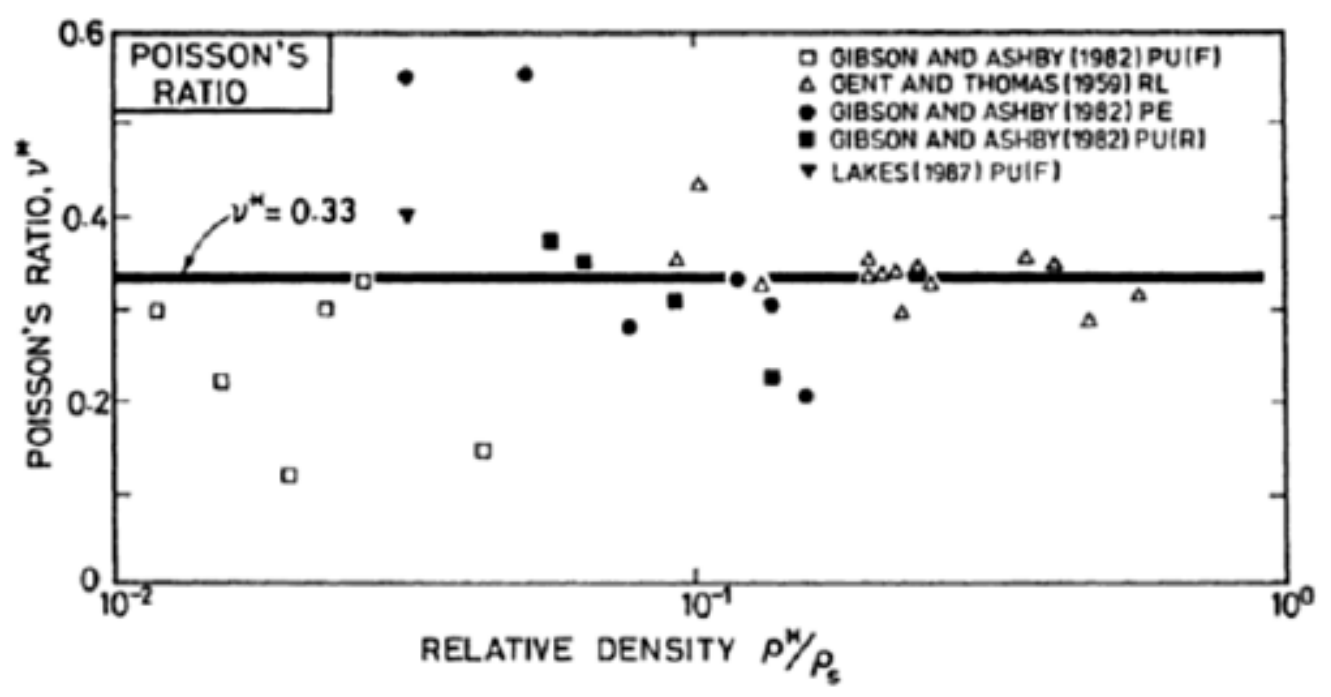

FIGURE 4.18.- Data for Poisson's ratio of foams as function of relative density $\left(\rho^{*} / \rho_{s}\right)$. Poisson's ratio is independent of the relative density. The average value of the data is around 1/3 (extracted from Gibson

$$
\text { et } \left.\text { al. }^{23}\right) \text {. }
$$

Finally, it is possible to conclude that for the shear properties a cross effect of the different studied characteristics are influencing the results. There is an effect of the changes in the final density of the nanocomposites, and also there is an effect of the cellular anisotropy changes. But all these effects are not enough to completely explain all the observed changes, and modifications of the polyurethane solid matrix by the nanoclays presence should be also taken into account (section 4.3.3).

\subsubsection{Mechanical properties in compression: Comparison with previous} results

Collaboration of CellMat Laboratory in different research projects (mentioned in Chapter 1) allow us the production and characterisation of several polyurethane nanocomposites foams based on other polyurethane systems. Concretely, NanCore project, oriented to the improvement of the mechanical properties, has given us a wide collection of results related with the mechanical properties of polyurethane foams. Thereby, a comparison with different materials is presented in this section, with the aim of placing the relative to the square of the density compression properties of BASF nanocomposites against other nanocomposites. In all cases we used nanoclays cloisite 30B as nanoparticles and the low shear mixing technique as the method to disperse in each polyol. The preparation and 
characterisation method was the same as those used for the polyurethane based foams of this thesis.

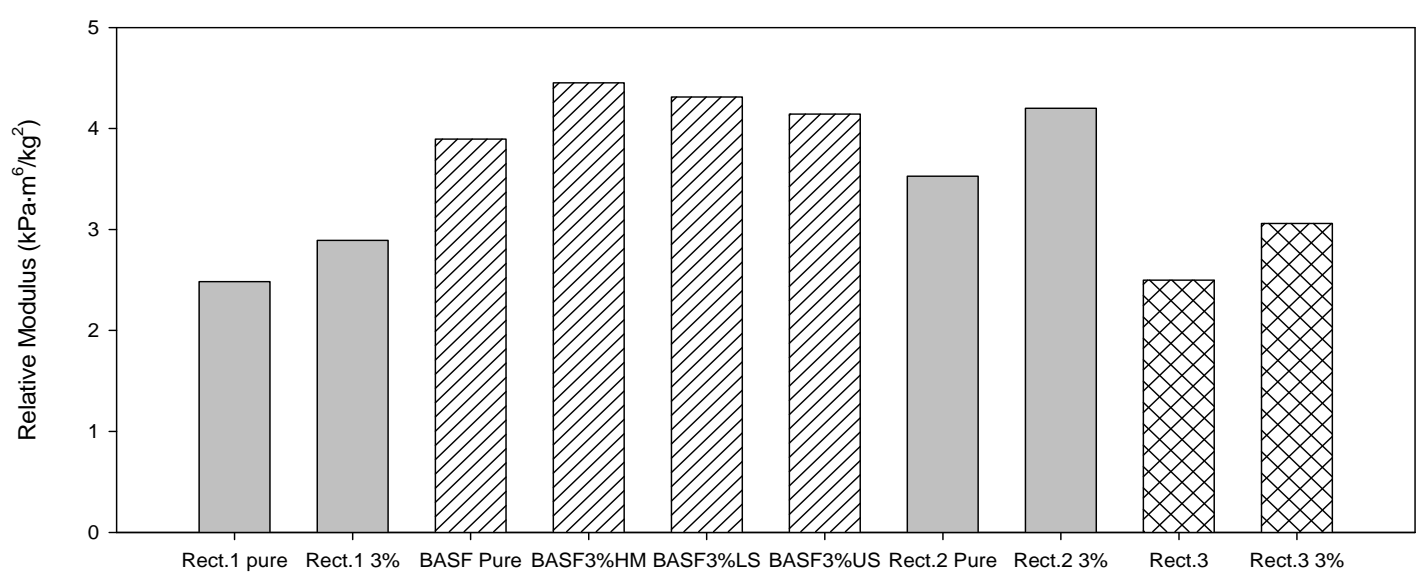

FIGURE 4.19.- Elastic Modulus relative to squared density, BASF formulation against different Recticel formulations.

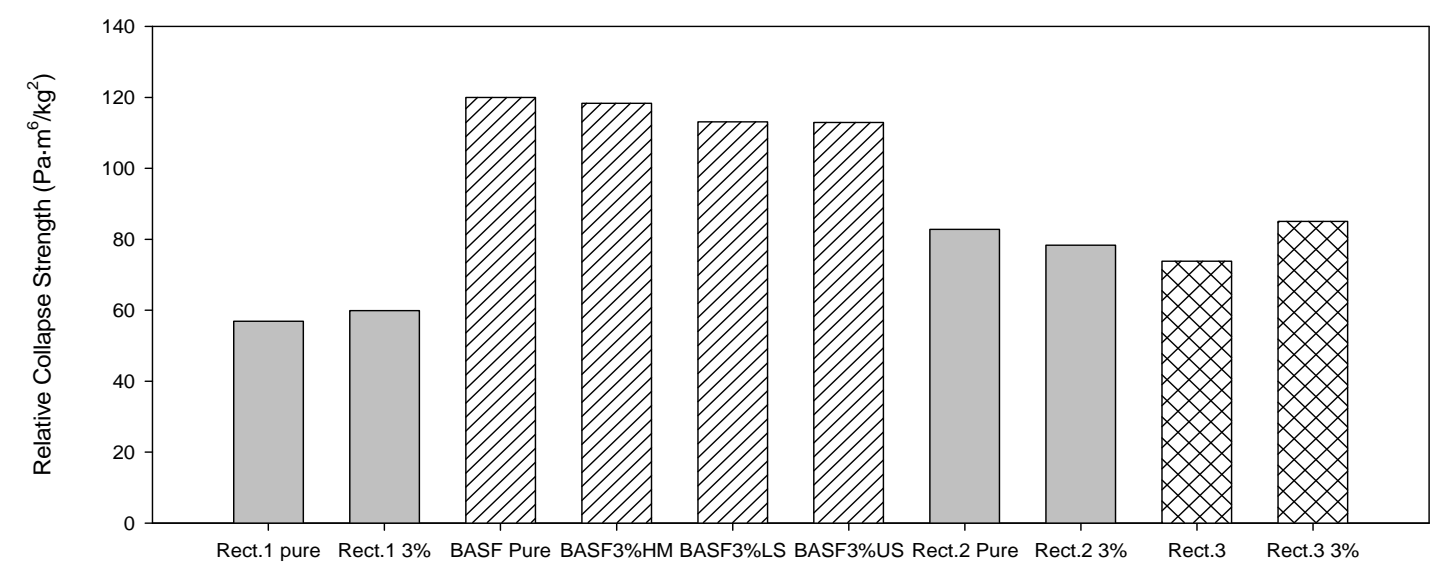

FIGURE 4.20.- Collapse Strength relative to the square of density, BASF formulation against different Recicel formulations.

It is possible to observe in Fig. 4.19 the Elastic Modulus relative to the square of density for different formulations and particles. The formulation studied in the present work, from BASF, it is represented without nanoparticles and with 3\% nanoclays concentration, and with the three different dispersion techniques. Beside these samples, three different Recticel blends are also included, without nanoparticles and with 3\% Nanoclays (Cloisite 30B). Recticel formulations named as MV and HV were the same employed for the dispersion techniques study, and the other Recticel formulation (Recticel 1) one extra with a free foaming density of 
$150 \mathrm{~kg} / \mathrm{m}^{3}$. Thereby, it is possible to observe that between the represented formulations, the BASF blend presents better properties, with and without nanoclays. It is also possible to conclude that the improvement over the final properties as consequence of the nanoclays inclusion is always very small, independently from the employed formulation.

Analogous results can be observed in Fig. 4.20 for the Collapse Strength relative to the squared density. Again, it is possible to observe that relative properties of the present work formulation presents very good values even for the unfilled material, and also that the inclusion of nanoclays in polyurethene foams produce a reduction of the collapse strenght.

\subsubsection{Thermal conductivity}

Thermal conductivity measurements were performed with a hot-disk transient plane source (TPS) thermal constant analyser. A disk-shaped TPS sensor with diameter $6.403 \mathrm{~mm}$ was used in all measurements. Table 7 shows the results of thermal conductivity measurements. The experimental procedure followed in these tests was explained in section 3.2.4.2. A small decrease of the thermal conductivity by the introduction of nanoclays was measured, even if a higher density is typically obtained for the nanocomoposite foam. Best results were obtained for the low shear mixing dispersion technique, with a $3.1 \%$ reduction with respect to the pure material.

TABLE 7.- Thermal conductivity results

\begin{tabular}{|c|c|c|c|}
\hline Material & $\begin{array}{l}\text { Thermal conductivity } \\
\qquad(\mathrm{mW} / \mathrm{m} \cdot \mathrm{k})\end{array}$ & $\begin{array}{l}\text { Standard deviation } \\
\qquad(\mathrm{mW} / \mathrm{m} \cdot \mathrm{k})\end{array}$ & $\begin{array}{l}\text { Insulation improvement with } \\
\text { respect to the pure material }\end{array}$ \\
\hline LV Pure & 38.40 & 0.22 & - \\
\hline LV 3\% HM & 37.34 & 1.32 & $2.7 \%$ \\
\hline LV 3\% LS & 37.20 & 0.23 & $3.1 \%$ \\
\hline LV 3\% US & 37.91 & 0.24 & $1.3 \%$ \\
\hline
\end{tabular}

Again, a considerable dispersion is obtained for HM technique, consistent with the density measurements. However, small differences between different techniques show that a good dispersion of the fillers does not imply an improvement of the insulation properties, i.e., a thermal conductivity reduction. A reduction of the thermal conductivity can be achieved with 
the addition of nanoclays and a poor dispersion. Part of these changes could be explained by the cell size reduction and open cell content variation, as will be discussed in the following section.

\subsubsection{Discussion}

A general change in the cell size distribution with a clear reduction of the cell size has been produced by the addition of the nanoclays. The change in the cell size distribution can be explained by the nucleation effect of nanoclays, the particles act as nucleation centres due to their low surface energy. The presence of a wider size distribution with a higher cell density could be related with a double generation of cells along the foaming process: the standard nucleation, which occurs in the polyurethane without nanoclays, and the nanoparticles nucleation, which is produced by the presence of nanoparticles. If cells are not nucleated at the same time, the cell growth will be different and a wide cell size distribution will appear.

On the other hand, Dynamic Mechanical Analysis studies suggest a clear interaction between nanoclays and polymer matrix. These facts have been corroborated by the SAXS study, where the peak associated to the basal plane of nanoclays shifts to lower angles indicating an increase in the inter-lamellar space, i.e. the nanoclays intercalation. These results were similar for all dispersion techniques employed, no significance difference has been observed for the materials produced with different dispersion techniques. So, although a variation of the dispersion quality in the polyol has been observed in the rheology characterization of the different dispersion techniques, these variations did not affect the nanoclays intercalation. All these results are in agreement with a theoretical result studied during the state of the art in Chapter $n=2$, the theory developed by Vaia ${ }^{17}$. Calculations showed that a complete layer separation in clays will occur only for very favourable polymersurface interactions, to get over the polymer confinement. When this is not possible, the employment of high shear forces of the particles during the preparation and the processing of the nanocomposite materials can produce a good dispersion, but the system nevertheless will be thermodynamically stable, and it will come back to the initial stage. Something similar is observed in the studied formulations: a good interaction between organo-modification and isocyanate reactive produces intercalation, but this intercalation is independent from the dispersion technique employed. The presence of hydroxyl groups in the nanoparticles functionalization, which have a great affinity with isocyanate, have a great influence in the intercalation: the power of the dispersion technique employed only affects to the quality of the dispersion but not to the intercalation. Moreover, although the employment of a high | 134 
effective dispersion technique does not have a clear effect in the exfoliation/intercalation (see Fig. 4.21), it has it in the dispersion as it was observed in the initial section of this chapter.

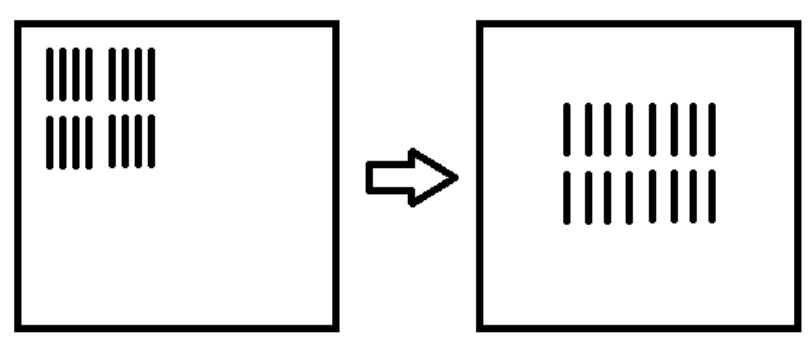

HM Dispersion
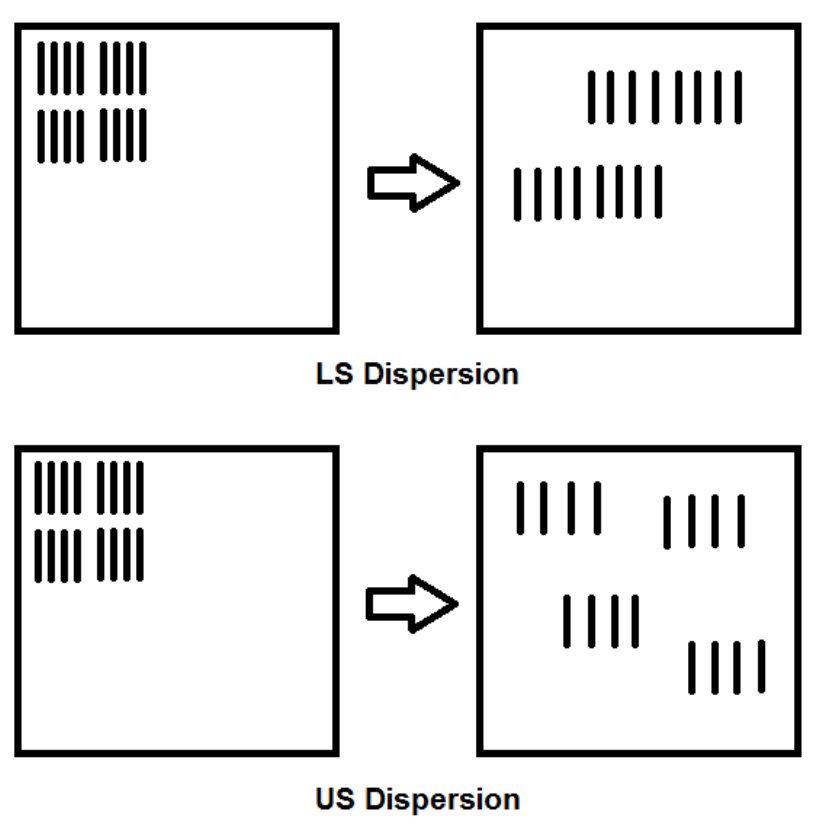

FIGURE 4.21. Dispersion quality and exfoliation

However, despite the intercalation achieved for all dispersion techniques, and the good dispersion for some of the methods used (and the reduction of cell size), mechanical properties were not significantly improved. As a matter of fact, best results are not obtained for the materials showing a better dispersion, more likely the opposite relationship has been observed: a better dispersion implies worse properties. This could be explained by a chemical interaction between the urethane groups and nanoclays ${ }^{12,17}$ (see Figure 4.22). H-bonds between urethane groups are largely responsible of mechanical properties of pure polyurethane, as they are highly present on the final material structure. Nanoclays could interact with these bonds, reducing the final number of them. So the expected increase in mechanical properties due to nanoclays is compensated by the lost in the mechanical properties due to the $\mathrm{H}$-bonds that were not formatted. And hence a better dispersion could 
imply the destruction of more $\mathrm{H}$-bonds, which would not be compensated by the higher properties of nanoclays and could result in a foamed nanocomposite with reduced properties (for instance we have observed a clear reduction of the compressive strength in our materials).

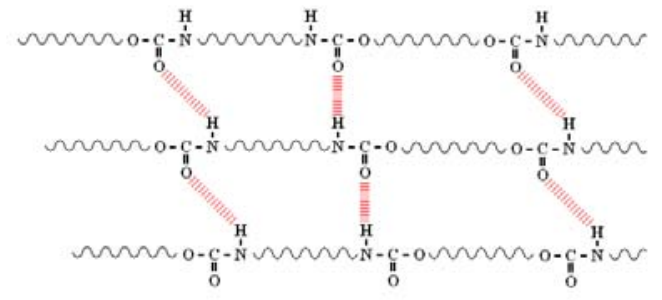

(a)

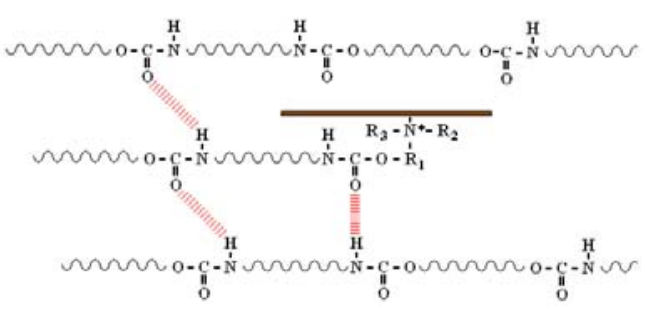

(b)

FIGURE 4.22 (a) Pure polyurethane structure: urethane groups and H-bonds; (b) Polyurethane infused with functionalized nanoclays: urethane groups, $\mathrm{H}$-bonds and nanoclays.

Another possible explanation for the mechanical properties behaviour is the changes in the cellular structure produced by the nanoclays addition. These changes could also be related with the final mechanical final properties, as it has been previously explained in the state of the art chapter. In the Gibson and Ashby relationships between solid and foam properties (Eq. 2 ), the exponent $n$ present in the scaling law governs the properties of foamed materials respect to solid ones can take values between 1 and 2 . For a lower reduction of the mechanical properties with the decrease of the density, cellular structure must be able to produce $n$ values close to 1 . Closed cell structures with a high cell size homogeneity (narrow cell size distributions) are related with a lower $n$ value for mechanical properties like elasticity modulus or compression collapse strength ${ }^{23,28,29}$. For other properties as the impact strength, toughness or fatigue behavior, microcellular structures (cell sizes lower than $10^{-6} \mathrm{~m}$ ) are required to reach these low $n$ values ${ }^{28,30,31}$. Once again, there is a double effect of nanoclays in polyurethane matrix in the present study: they have a reinforcement effect over the solid matrix due to their higher mechanical properties, but also produce wider cell size distributions (Figure 4.3.1.2.2). These results could produce a higher value for the exponent $n$ in the Gibson and Ashby law, and then a reduction of final properties.

Finally, it is possible to conclude that mechanical behavior of the foamed rigid polyurethane infused with nanoclays produced with different dispersion techniques could be affected by the simultaneous effect of both explanations: an interaction between $\mathrm{H}$-bonds and nanoclays which reduces mechanical properties for high concentrations or good dispersion of nanoclays, and the presence of a wider cell size distribution able to reduce final properties due 
to a lower mechanical behavior. These two effects contribute in the direction of having a discrete improvement of the Elastic Modulus and a slight reduction of the collapse strength.

Thermal conductivity has been reduced by the addition of nanoclays. This reduction is an expected result due to the relationship between cell size and thermal conductivity that is explained in the following paragraph. Four mechanisms are involved on thermal conductivity of polymeric foams: conduction along the solid polymer $\left(q^{s}\right)$, conduction through the gas $\left(q^{g}\right)$, thermal radiation $\left(q^{r}\right)$, and convection within the cells $\left(q^{c}\right)$. The total heat flow $\left(q^{t}\right)$ is a result of the four contributions and can be expressed by a superposition of each mechanism taken separately ${ }^{32-37}$ :

$$
q^{t}=q^{s}+q^{g}+q^{r}+q^{c}
$$

The convective heat transfer is assumed to be negligible ${ }^{35,38}$ because of the very small cell size $(350-500 \mu \mathrm{m})$. Foaming agent and solid polymer conductivity can be considered in a first approximation the same for all manufactured samples. So the reduction of thermal conductivity must be produced by the variation of the thermal radiative term. In the diffusion approximation (in this process, the heat flux is proportional to the local gradient of the potential, in this case the black body emissive power $\left.\sigma T^{4}\right)$, the radiative heat flux $q_{r}(x)$ can be expressed as follows ${ }^{39}$ :

$$
q_{r}(x)=\frac{4}{3 K_{e, R}} \frac{\partial e_{b}}{\partial x}=\frac{-16 \sigma T^{3}}{3 K_{e, R}} \frac{\partial T}{\partial x}=-\lambda_{r} \frac{\partial T}{\partial x}
$$

where $\lambda_{r}$ is the radiative conductivity. Foams used in real applications are usually thick enough (several millimetres thick) to be considered optically thick; therefore, the radiative flux can be approximated by Rosseland equation ${ }^{35}$ as follows:

$$
\lambda_{r}=\frac{16 n^{2} \sigma T^{3}}{3 K_{e, R}}
$$

Where $n$ is the effective index of refraction and $K_{e, R}$ is the Rosseland mean extinction coefficient. For polymer foams, $n$ is close to one. This approximation is valid in this study because the foams under analysis have a volume of gas higher than $95 \%$. Glicksman and coworkers $^{35,} 40-42$ proposed an equation to predict the extinction coefficient of closed-cell polyurethane foams. They considered pentagonal dodecahedral cells and an isotropic foam as a set of randomly oriented blackbody struts. They neglected scattering by cell walls. The strut 
cross section was constant and occupied two-thirds of the area of an equilateral triangle formed at the vertices; the Glicksman extinction coefficient $\left(\mathrm{K}_{\mathrm{G}}, \mathrm{Eq} .6\right)$ is a function of the cell diameter $(\phi)$, the foam density $\left(\rho_{f}\right)$, and the solid polymer density $\left(\rho_{s}\right)$ :

$$
K_{G}=4.10 \frac{\sqrt{f_{s} \frac{\rho_{f}}{\rho_{s}}}}{\phi}+\left(1-f_{S}\right) \frac{\rho_{f}}{\rho_{s}} K_{W}
$$

Where $f_{S}$ is the mass fraction in the struts, 4.10 is a constant related to the cell geometry and $K_{w}$ is the extinction coefficient of the solid polymer. As it has been previously mentioned, all terms in this expression except the cell size can be considered in a first approximation the same for the materials with or without nanoclays using different dispersion techniques. So, a reduction of the cell size produces an increase of $K$, which produces a reduction of $\lambda_{r}$ and with a reduction of the total value of $\lambda . K_{G}$ can be estimated for the different dispersion techniques. Assuming a fixed mass fraction in the struts of $0.7^{11}$ and an extinction coefficient on solid polymer of $60000 \mathrm{~m}^{-135}$. The extinction coefficient has been calculated using equation 9 . The results are showed in table 8.

TABLE 8.- Glicksman extinction coefficient for the different dispersion techniques.

\begin{tabular}{cc}
\hline Material & $\mathrm{K}_{\mathrm{G}}\left(\mathrm{cm}^{-1}\right)$ \\
\hline LV Pure & 25,9 \\
\hline LV 3\% HM & 29,0 \\
\hline LV 3\% LS & 27,6 \\
\hline LV 3\% US & 28,2 \\
\hline
\end{tabular}

These values show how the reduction of the cell size, that is the only parameter that has been changed for the different techniques in this estimation, has a clear impact over the Glicksman extinction coefficient.

Figure 4.23 confirms this relationship between cell size variations and thermal conductivity reduction: a decrease in the cell size implies a decrease in the thermal 
conductivity. The only material that does not completely fit with this trend is the produced by ultrasounds.

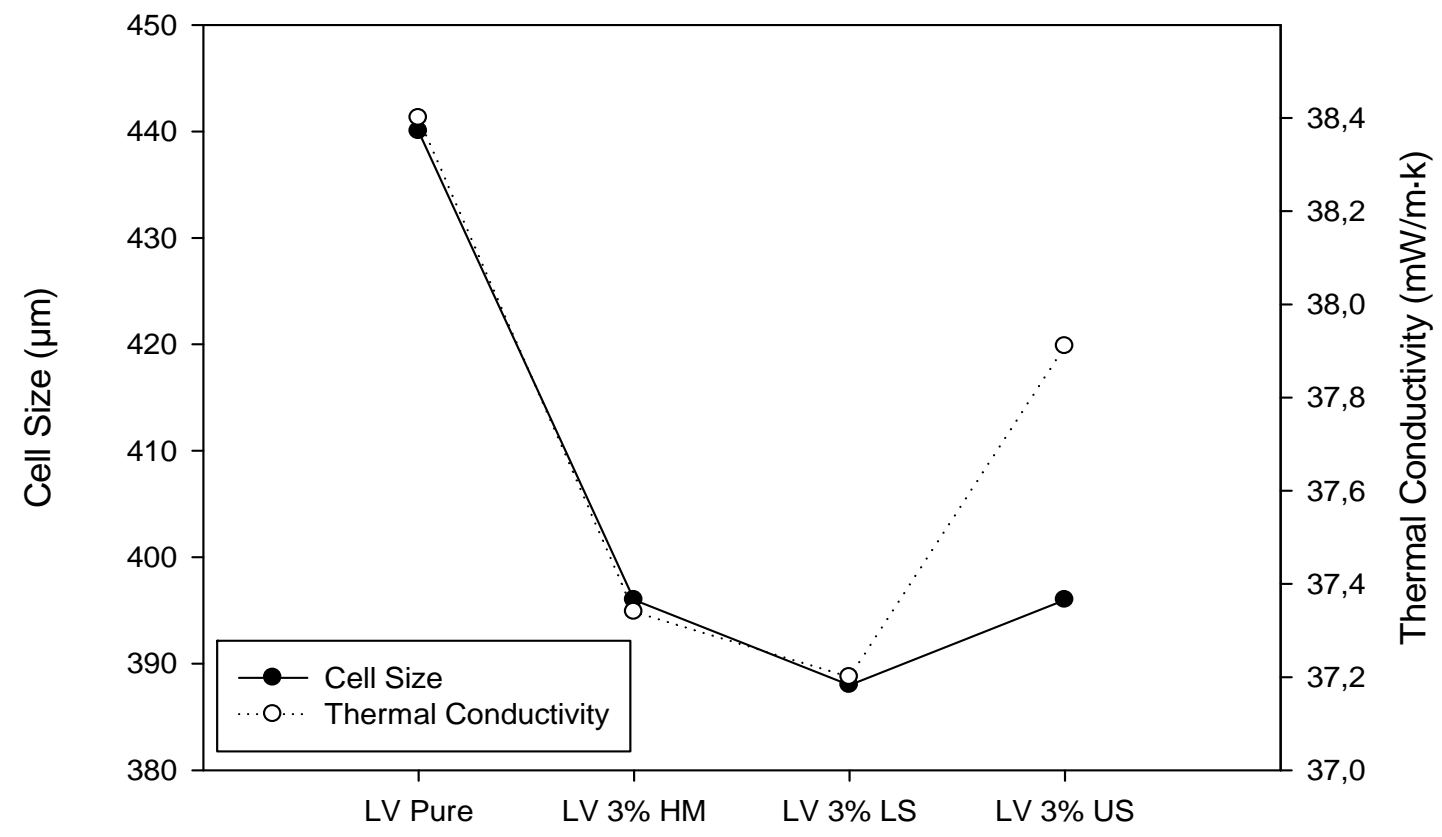

FIGURE 4.23. Thermal conductivity and cell size, for the different nanoclays concentration

At this point, other cellular characteristics could be playing an important role. Some calculations can be done at this respect: if a prediction of the thermal conductivity radiative term is made only increasing the $\mathrm{K}_{\mathrm{G}}$ value from 25 to $28 \mathrm{~cm}^{-1}$, a variation of the conductivity of only $0.25 \mathrm{~mW} / \mathrm{m} \cdot \mathrm{K}$ is produced, showing that this change does not completely explains the change of the measured conductivity. Other cellular characteristics could be playing an important role. The open cell content will be studied now as a possible factor.

Open cell content has a high weight in the thermal conductivity properties of polymeric foams ${ }^{14}$, as it has been observed in the state of the art chapter. The presence of a high amount of open cells (in polyurethane foams with a foaming agent inside their cells with a thermal conductivity lower than air) can produce a significant increase of the final thermal conductivity by the rapid exchange of the foaming agent with atmospheric air ${ }^{43}$. But also, the presence of higher amounts of open cells imply that the infrared radiation can find simpler and quicker paths through the foam, resulting in a lower extinction coefficient $\left(\mathrm{K}_{\mathrm{e}, \mathrm{R}}\right)$ and as a consequence in a high thermal conductivity. 
As it has been explained in the experimental chapter, thermal conductivity measurements were conducted a long time after foams production. The foaming agent used in the studied material was water, which react with the isocyanate producing $\mathrm{CO}_{2}$, with lower thermal conductivity than air $\left(25.3 \mathrm{~mW} \cdot \mathrm{m}^{-1} \cdot \mathrm{k}^{-1}\right.$ at $20^{\circ} \mathrm{C}$ for air versus $14.5 \mathrm{~mW} \cdot \mathrm{m}^{-1} \cdot \mathrm{k}^{-1}$ at $20^{\circ} \mathrm{C}$ for $\left.\mathrm{CO}_{2}\right)$. As a drawback, $\mathrm{CO}_{2}$ diffusion in polyurethane foams is really quick, in fact only 40 days after material production a complete gas exchange between atmospheric air and $\mathrm{CO}_{2}$ has been produced $^{35}$. This will be shown in the next chapter, in which a study of the thermal conductivity evolution with time is presented. For this reason, and taking into account that the thermal conductivity measurements were made at least 2 months after materials production, it can be concluded that all the materials presented only atmospheric air inside the cells, when thermal conductivity test were performed.

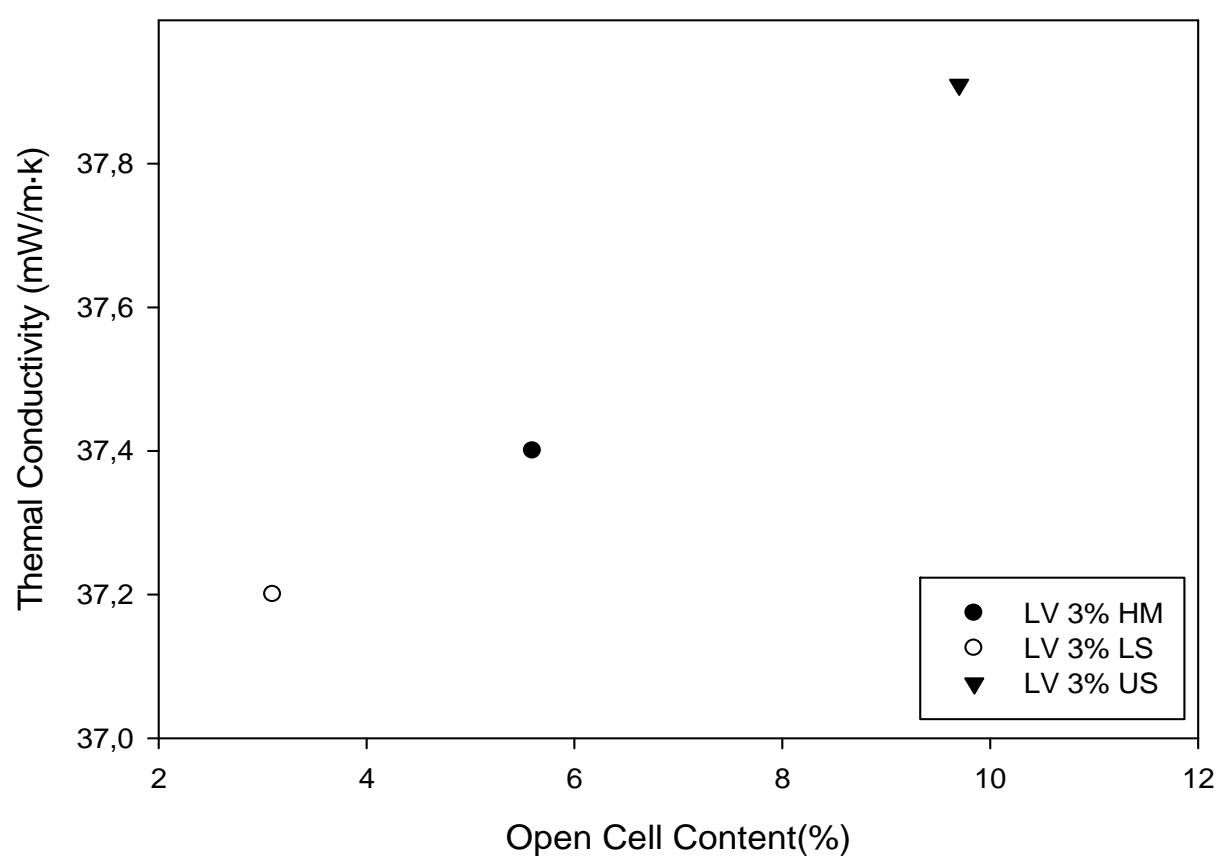

FIGURE 4.23.- Thermal conductivity vs open cell content for foamed nanocomposites produced using different dispersion techniques

Comparing the experimental thermal conductivity and open cell content of the nanocomposite foams, it is possible to observe a clear relation between both properties. So, it is possible to conclude that although inclusion of nanoclays produces a cell size reduction that produces a thermal conductivity decrease, differences between the thermal conductivities of the samples performed with different dispersion techniques could also be related with the open cell content. As it was shown in Table 4.2 the open cell content of HM (5.6\%) and LS (3.1\%) | 140 
materials was lower than that of US materials (9.7\%). Therefore, as these three materials have very similar cell sizes distributions, the thermal conductivities are related with the open cell content as it is shown in Fig. 4.23.

\section{4.- Summary and conclusions}

This chapter has been focused in evaluation the effect of the dispersion quality of the clays in the polyol blend on the structure and properties of polyurethane foams filled with $3 \% \mathrm{wt}$. of nanoclays. The main results obtained for each property are:

- Density measurements: the inclusion of nanoparticles in polyurethane foams produced a measurable change in final foams density. Nanofillers inclusion produced a small density reduction only in the low shear mixing technique foam, but in general terms the macroscopic density tends to increase when nanoclays are added.

- Cell size: The presence of nanoclays produce a reduction in the cell size, independently from the dispersion technique used. The average cell size reduction is close to $10 \%$ with respect to the pure material.

- Cellular anisotropy: no clear effects on cellular anisotropy were obtained (around a $10 \%$ variation with respect to the pure material) for the different dispersion techniques.

- Open cell content: No clear changes in the open cell content have been observed with the inclusion of nanoclays, independently from the dispersion technique employed.

- Cell size distribution: The normalized standard deviation (NSD) of the cell size distribution experienced a clear increase (approx. from 0.2 for pure material to 0.3 for the different techniques). The asymmetry coefficient presented a small reduction when the clays were added.

- Nucleation efficiency: nucleation efficiency of nanoclays was studied for the different dispersion techniques, showing poor efficiency in comparison with the results obtained by other authors.

- Nanoclays intercalation: X-ray diffraction experiments performed over the polyurethane samples produced with different techniques showed an intercalation of the nanoclays in the polymeric matrix. DMA studies corroborated this result, showing 
a clear effect of nanoclays over the polymeric chains mobility, as it can be concluded by the increase in $T_{g}$ and the decrease of $\tan \delta$ in the glass transition region.

- Compression properties (relative to the square of the density): the presence of nanoclays in polyurethane foams has supposed a small increase of the elastic modulus (not correlated with the dispersion quality) and a decrease of the compression strength (near to $6 \%$ with respect to the pure material for the ultrasonication dispersion technique). These effects seem to be connected with two possible facts: the modification of the cellular structure, with an increase in the width of the cell sizes distribution, and the relationship between the dispersion quality of the particles and a possible chemical interaction of nanoclays and polyurethane matrix. This interaction implies a destruction of $\mathrm{H}$-bonds between polymeric chains (which have a significant impact on the mechanical properties of unfilled foams) by the nanoclays presence. Then, as a powerful dispersion technique implies a better dispersion, a powerful dispersion technique will also imply a higher interaction between the nanofillers and the PU matrix, and this will result in worse mechanical properties. As it has been proven that intercalation of the nanoclays is achieved independently from the dispersion technique employed, a better dispersion will imply a higher filler-matrix interaction and as consequence a reduction of the matrix properties.

- Shear properties: small changes has been observed in the value of the shear modulus with the inclusion of nanoclays, and a clear difference between foaming direction value (higher value) and perpendicular to foaming direction value (lower value) has been observed, showing the importance for the analysed materials. There is a clear correlation between the measured shear modulus and the cellular anisotropy.

- Thermal conductivity: Thermal conductivity has been reduced by the addition of nanoclays. This reduction is an expected result due to the relationship between cell size and thermal conductivity. An increase of the extinction coefficient has been observed, but it does not completely explain the changes in the thermal conductivity. Other factors as the open cell content have an influence over the observed changes.

Finally, it can be concluded from this study the independence of nanoclays inclusion from the dispersion technique employed. For this reason, low shear dispersion technique was selected in order to realise a study on the nanoclays concentration effect over the polyurethane foams final properties. The results of this study will be presented in the next chapter, playing special attention to the thermal properties and their modelling. 
${ }^{1}$ I. Rhoney, S. Brown, N. E. Hudson, R. A. Pethrick, Influence of processing method on the exfoliation process for organically modified clay systems. I. Polyurethanes, Journal of applied polymer science, 91(2), 1335-1343 (2004)

${ }^{2}$ F. J. Galindo-Rosales, P. Moldenaers, J. Vermant, Assessment of the dispersion quality in polymer nanocomposites by rheological methods, Macromolecular Materials and Engineering, 296 (3-4), 331-340, (2011)

${ }^{3}$ H. H. Winter, Three views of viscoelasticity for Cox-Merz materials, Rheologica acta, 48(3), 241-243, (2009)

${ }^{4}$ M. S. Wang, T. J. Pinnavaia, Clay-polymer nanocomposites formed from acidic derivatives of montmorillonite and an epoxy resin, Chemistry of Materials, 6(4), 468-474 , (1994)

${ }^{5}$ K. Liang, ShQ. Shi, Nanoclay filled soy-based polyurethane foam, Journal of Applied Polymer Science, 119(3):1857-63, (2011)

${ }^{6}$ Ł. Piszczyk, M. Strankowski, M. Danowska, J. T. Haponiuk, M. Gazda, Preparation and characterization of rigid polyurethane-polyglycerol nanocomposite foams, European Polymer Journal, 48(10), 1726-1733, (2012)

${ }^{7}$ M. Thirumal, D. Khastgir, N. K. Singha, B. S. Manjunath, Y. P. Naik, Effect of foam density on the properties of water blown rigid polyurethane foam, Journal of Applied Polymer Science, 108(3), 1810-1817, (2008)

8 J. S. Colton, N. P. Suh, The nucleation of microcellular thermoplastic foam with additives: Part I: Theoretical considerations, Polymer Engineering \& Science, 27(7), 485-492, (1987)

${ }^{9}$ M. Mitsunaga, Y. Ito, S. S. Ray, M. Okamoto, K. Hironaka, Intercalated polycarbonate/clay nanocomposites: nanostructure control and foam processing, Macromolecular Materials and Engineering, 288(7), 543-548 (2003)

${ }^{10}$ J. Shen, C. Zeng, L. J. Lee, Synthesis of polystyrene-carbon nanofibers nanocomposite foams, Polymer, 46(14), 5218-5224, (2005)

${ }^{11}$ S. Pardo-Alonso, E. Solórzano, S. Estravís, M. A. Rodríguez-Perez, J. A. de Saja, In situ evidence of the nanoparticle nucleating effect in polyurethane-nanoclay foamed systems, Soft Matter, 8(44), 11262-11270 (2012)

${ }^{12}$ X. Cao, L. J. Lee, T. Widya, C. Macosko, Polyurethane/clay nanocomposites foams: processing, structure and properties, Polymer, 46(3), 775-783, (2005)

${ }^{13}$ M. Modesti, A. Lorenzetti, S. Besco, Influence of nanofillers on thermal insulating properties of polyurethane nanocomposites foams, Polymer Engineering \& Science, 47(9), 1351-1358, (2007) 
${ }^{14}$ G. Harikrishnan, T. U. Patro, D. V. Khakhar, Polyurethane foam-clay nanocomposites: nanoclays as cell openers, Industrial \& Engineering Chemistry Research, 45(21), 7126-7134, (2006)

15 P. Spitael, C. W. Macosko, R. B. McClurg, Block copolymer micelles for nucleation of microcellular thermoplastic foams, Macromolecules, 37(18), 6874-6882 (2004)

16 X. Han, C. Zeng, L. J. Lee, K. W. Koelling, D. L. Tomasko, Extrusion of polystyrene nanocomposite foams with supercritical CO2, Polymer Engineering \& Science, 43(6), 1261$1275,(2003)$

${ }^{17}$ R. A. Vaia, E. P. Giannelis, Lattice model of polymer melt intercalation in organically-modified layered silicates, Macromolecules, 30(25), 7990-7999, (1997)

${ }^{18}$ S. Vadukumpully, J. Paul, N. Mahanta, S. Valiyaveettil, Flexible conductive graphene/poly (vinyl chloride) composite thin films with high mechanical strength and thermal stability, Carbon, 49(1), 198-205. (2011)

${ }^{19}$ A. M. Diez-Pascual, M. Naffakh, M. A. Gomez, C. Marco, G. Ellis, M. T. Martınez, A. Ansón, J. M. González-Domínguez, Y. Martínez-Rubic, B. Simardc, Development and characterization of PEEK/carbon nanotube composites, Carbon, 47(13), 3079-3090, (2009)

${ }^{20}$ R. Verdejo, F. Barroso-Bujans, M. A. Rodriguez-Perez, J. A. de Saja, M. A. Lopez-Manchado, Carbon nanotubes provide self-extinguishing grade to silicone-based foams, Journal of Materials Chemistry, 18(33), 3933-3939 (2008)

${ }^{21}$ H. S. Xia, M. Song, Preparation and characterization of polyurethane-carbon nanotube composites, Soft Matter, 1(5), 386-394 (2005)

${ }^{22}$ D. Yan, L. Xu, C. Chen, J. Tang, X. Ji, Z. Li, Enhanced mechanical and thermal properties of rigid polyurethane foam composites containing graphene nanosheets and carbon nanotubes, Polymer International, 61(7), 1107-1114. (2012)

${ }^{23}$ L. J. Gibson, M. F. Ashby, Cellular solids: structure and properties, Pergamon Press, Oxford, (1988)

${ }^{24}$ M.A. Rodríguez Pérez, J. Lobos Martín, C. Pérez Muñoz, J. S. Sáez, L. M. González Gutierrez, M. D. Carpio, Mechanical Behaviour at Low Strains of LDPE Foams with Cell Sizes in the Microcellular Range: Advantages of Using these Materials in Structural Elements, Cellular Polymers, 27(6), 347-362, (2008)

${ }^{25}$ M.A. Rodríguez-Pérez, J. I. González-Peña, N., Witten, J. A. de Saja, The effect of cell size on the physical properties of crosslinked closed cell polyethylene foams produced by a high pressure nitrogen solution process, Cellular Polymers, 21(3), 165-194, (2002)

${ }^{26}$ A. T. Huber, I. J. Gibson, Anisotropy of foams, Journal of Materials Science, 23(8), 3031-3040, (1988) 
${ }^{27}$ A. Lorenzetti, D. Hrelja, S. Besco, M. Roso, M. Modesti, Improvement of nanoclays dispersion through microwave processing in polyurethane rigid nanocomposite foams, Journal Of Applied Polymer Science, 115(6), 3667-3674, (2010)

${ }^{28}$ D. Eaves, Handbook of Polymer Foams, Rapra Technology, United Kingdom, (2004)

${ }^{29}$ E. Solórzano, Espumas de Aluminio: Proceso de Espumado, Estructura Celular y Propiedades, PhD. Thesis, Universidad de Valladolid, (2008)

${ }^{30}$ V. Kumar, Microcellular Polymers: Novel Materials for $21^{\text {st }}$ Century, Progress in Rubber and Plastics Technology, 12(3), 207-223, (1993)

${ }^{31}$ S.T. Lee, Foam Extrusion: Principles and Practice, Technomic Publishing Company, LancasterPennsylvania, (2000)

32 A. Cunningham, D. Sparrow, Rigid polyurethane foam: What makes it the most effective insulant?, Cellular polymers, 5(5), 327-342, (1986)

${ }^{33}$ C. J. Tseng, M. Yamaguchi, T. Ohmori, Thermal conductivity of polyurethane foams from room temperature to $20 \mathrm{~K}$, Cryogenics, 37 (6), 305-312, (1997)

${ }^{34}$ J. Kuhn, H. P. Ebert, M. C. Arduini-Schuster, D. Büttner, J. Fricke, Thermal transport in polystyrene and polyurethane foam insulations, International Journal of Heat and Mass Transfer, 35(7), 1795-1801, (1992)

${ }^{35}$ L. R. Glicksman, In Low Density Cellular Plastics: Physical Basis of Behaviour; Hilyard, N. C.; Cunningham, A., Eds.; Chapman \& Hall: London, Chapter 5, (1994)

${ }^{36}$ M.A. Rodríguez-Pérez, O. Alonso, J. Souto, J. A. De Saja, Thermal conductivity of physically crosslinked closed cell polyolefin foams, Polymer Testing, 16(3), 287-298, (1997)

${ }^{37}$ G. W. Ball, Proceeding of IOM Polyurethanes Conference 1994, 10, 257 (1994)

${ }^{38}$ O. A. Almanza, M. A. Rodríguez-Pérez, J. A. De Saja, Prediction of the radiation term in the thermal conductivity of crosslinked closed cell polyolefin foams, Journal of Polymer Science Part B: Polymer Physics, 38(7), 993-1004, (2000)

${ }^{39}$ R. Siegel, J. R. Howell, Thermal Radiation Heat Transfer; Taylor \& Francis: London, (1992)

${ }^{40}$ L. R. Glicksman, M. Torpey, Proceedings of Polyurethane World Congress, Aachen, Germany, (1987)

${ }^{41}$ L. R. Glicksman, Heat transfer and ageing of cellular foam insulation, Cellular Polymers, 10(4), 276-293, (1991)

${ }^{42}$ M. A. Schuetz, L. R. Glicksman, A basic study of heat transfer through foam insulation, Journal of Cellular Plastics, 20(2), 114-121, (1984) 
Chapter 4: Influence Of The Formulation And Dispersion Technique Employed

${ }^{43}$ C. J. Hoogendorn, Thermal ageing, Low Density Cellular Plastics, Cunningham, A., Hilyard, N.C., Eds.; Chapman and Hall: London, (1994) 

CHAPTER 5:

NANOCLAYS CONCENTRATION: ETEC TS

ON MECHANICAL PROPERIIES AND

THERMALCONDUCTIVTYY 



\section{NANOCLAYS CONCENTRATION: EFFECTS ON MECHANICAL PROPERTIES AND THERMAL CONDUCTIVITY}

\subsection{Objectives}

The main objective of this chapter is to analyse the effect of nanoclays concentration on the structure, thermal and mechanical properties of a rigid polyurethane system. A particular formulation, a specific type of functionalized nanoclay and a given dispersion technique of the nanoparticles have been selected, with the objective of reaching a deeper compression of this system. A complete morphological characterization has been performed, with special attention to the cellular structure, an aspect not studied in detail on previous publications as it was mentioned in chapter 2 . With all the data obtained from the characterisation and with the use of different theoretical models, the origin of the changes in the thermal conductivity will be identified, to establish the influence of the different parameters that have been modified by the nanoclays presence. In addition, the material properties in compression and shear have been also analysed in detail.

\subsection{Materials}

The following materials have been used in this section:

$>$ BASF formulation (see table 3.1)

Nanoclays Cloisite 30B (see table 3.2)

The concentrations of nanoclays selected were $0.5,1,3$ and 5\%, and the employed dispersion technique was low shear mixing (see table 3.3). In this study the size of the used mold was $310 \times 250 \times 60 \mathrm{~mm}^{3}$, which is a longer mould than the one used in the previous chapter $\left(110 \times 110 \times 80 \mathrm{~mm}^{3}\right)$. This change was originated by the sample size required by the Holometrix Heat Flow Meter, that allows accurate measurements of the thermal conductivity (see section 3.2.4.1). This modification together with the use of a different polyurethane batch, could be the origin of the differences between some of the properties measured for the materials containing 3wt\% nanoclays in this chapter with respect to the properties of materials with the same nominal composition included in the previous chapter. The foams were produced using the methodology described in section 3.1.3. 


\subsection{Characterization}

\subsubsection{Structural characterization}

\subsubsection{Density}

The density of the foams is presented in table 5.1. The density behaviour with the amount of nanoclays in the final foams is similar to the behaviour observed in the study of the different dispersion techniques of Chapter 4. As it can be observed the macroscopic density tends to increase when nanoclays are added. As it was previously discussed, the reason for this slight growth could be connected with higher viscosity of the initial blend when clays are infused $^{1,2}$, combined with the fact that nanofillers density (Cloisite $30 \mathrm{~B}-1980 \mathrm{~kg} / \mathrm{m}^{3}$ ) is higher than that of the reference foam (around $50 \mathrm{~kg} / \mathrm{m}^{3}$ ). This agrees with the fact that the density increases with the amount of nanoclays infused in the foams. Furthermore, despite nanoclays were dehydrated in a vacuum oven for several hours prior to their incorporation and dispersion in the polyol blend (see section 3.1), this do not always guarantee the complete absence of water in the nanoclays that could act as chemical blowing agent. Although the desorbed water molecules that absorb the cations between interlayers of clay evaporate in the temperature range of $50-170 \circ \mathrm{C}$, the dehydroxylation of bound water molecules from the crystal lattice of pristine clay occurs in the temperature range of $450-900{ }^{\circ} \mathrm{C}^{3,4}$. Anyway, the consequences of a possible small amount of absorbed water in the clays is not observed in our results and probably only play a role for lower nanoclays concentrations, where the effect of the viscosity and the nanoclays higher density is small.

TABLE 5.1. Density of the manufactured materials

\begin{tabular}{ccc}
\hline $\begin{array}{c}\text { Sample (nanoclays } \\
\text { concentration \%wt.) }\end{array}$ & Density $\left(\mathrm{Kg} / \mathrm{m}^{3}\right)$ & $\begin{array}{c}\text { Standard } \\
\text { deviation }\left(\mathrm{Kg} / \mathrm{m}^{3}\right)\end{array}$ \\
0 & 52,96 & 0,23 \\
0.5 & 53,78 & 0,95 \\
1 & 54,13 & 1,40 \\
3 & 55,09 & 0,30 \\
5 & 56,10 & 0,94 \\
\hline
\end{tabular}

Finally, as it was also commented in the previous chapter, these changes in density (4\% variation with respect to the pure material for the sample containing $5 \%$ nanoclays) are small, 
as polyurethane foam density is very sensitive to small changes in environmental conditions, like moisture and temperature, and to small changes in mixing times ${ }^{5}$.

\subsubsection{Cellular structure}

Figure 5.1 shows examples of micrographs of the samples with different nanoclays concentration.

a)

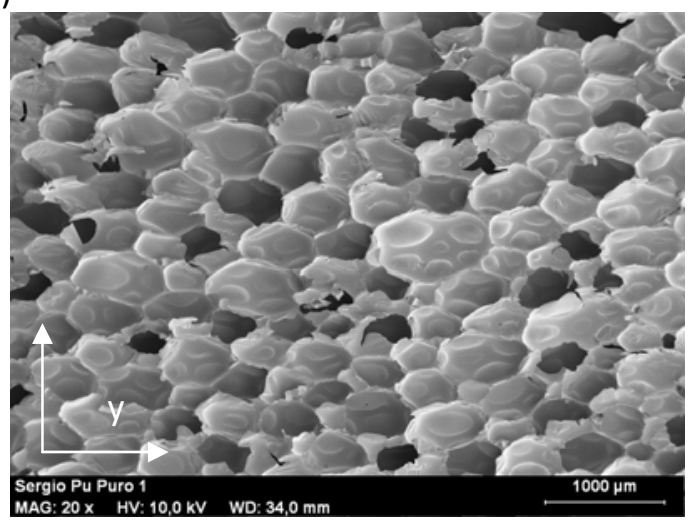

c)

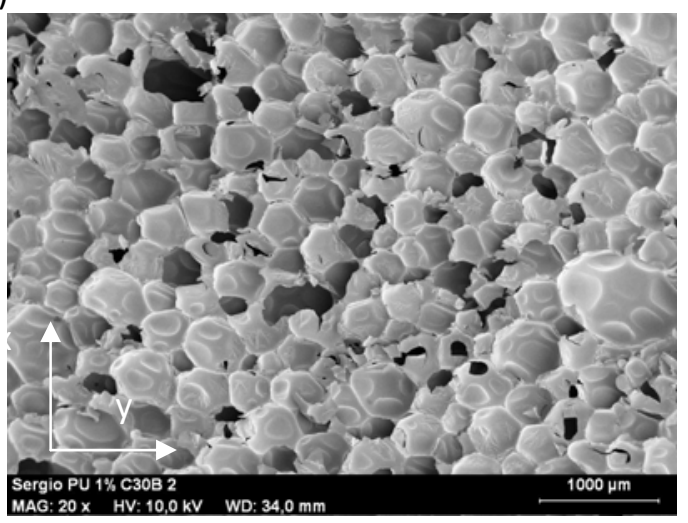

b)

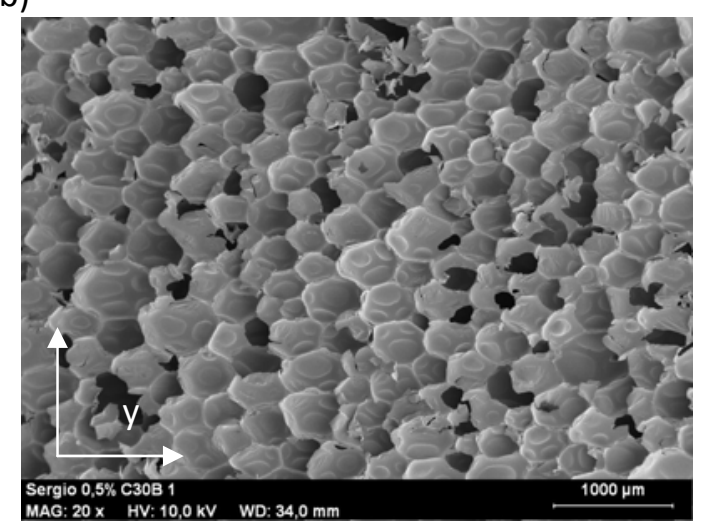

d)

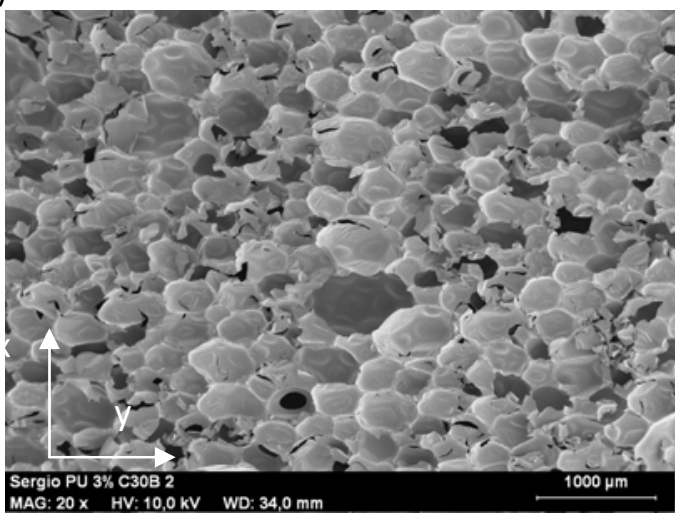

e)

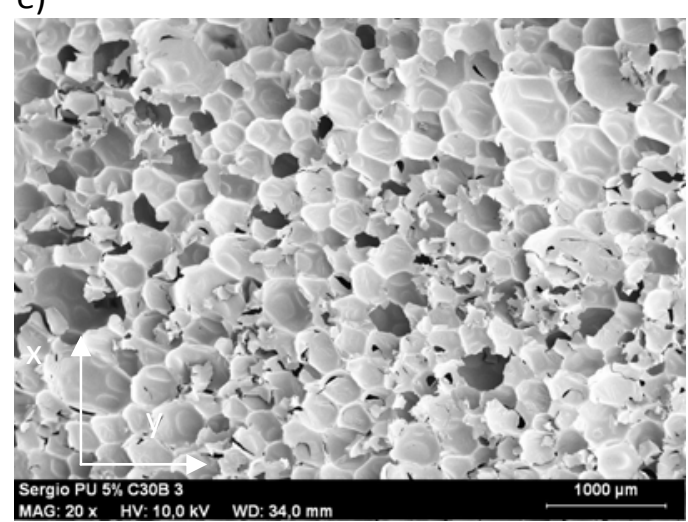

FIGURE 5.1 SEM images: (a) Pure material, (b) with $0.5 \%$ nanoclays, (c) with $1 \%$ nanoclays, (d) with $3 \%$ nanoclays, (e) with $5 \%$ nanoclays

On these

images it is possible to observe a reduction of the cell size when the clays are added. This 
effect is clear even for the lower nanoclays concentration, and apparently for higher amounts of clays the effect is even higher. Another easily observable effect is cellular anisotropy. Anisotropy can be observed for pure material and materials with lower nanoclays concentration, with larger cells in the growing direction (y direction). As the amount of clays is increased, this effect is hardly observed.
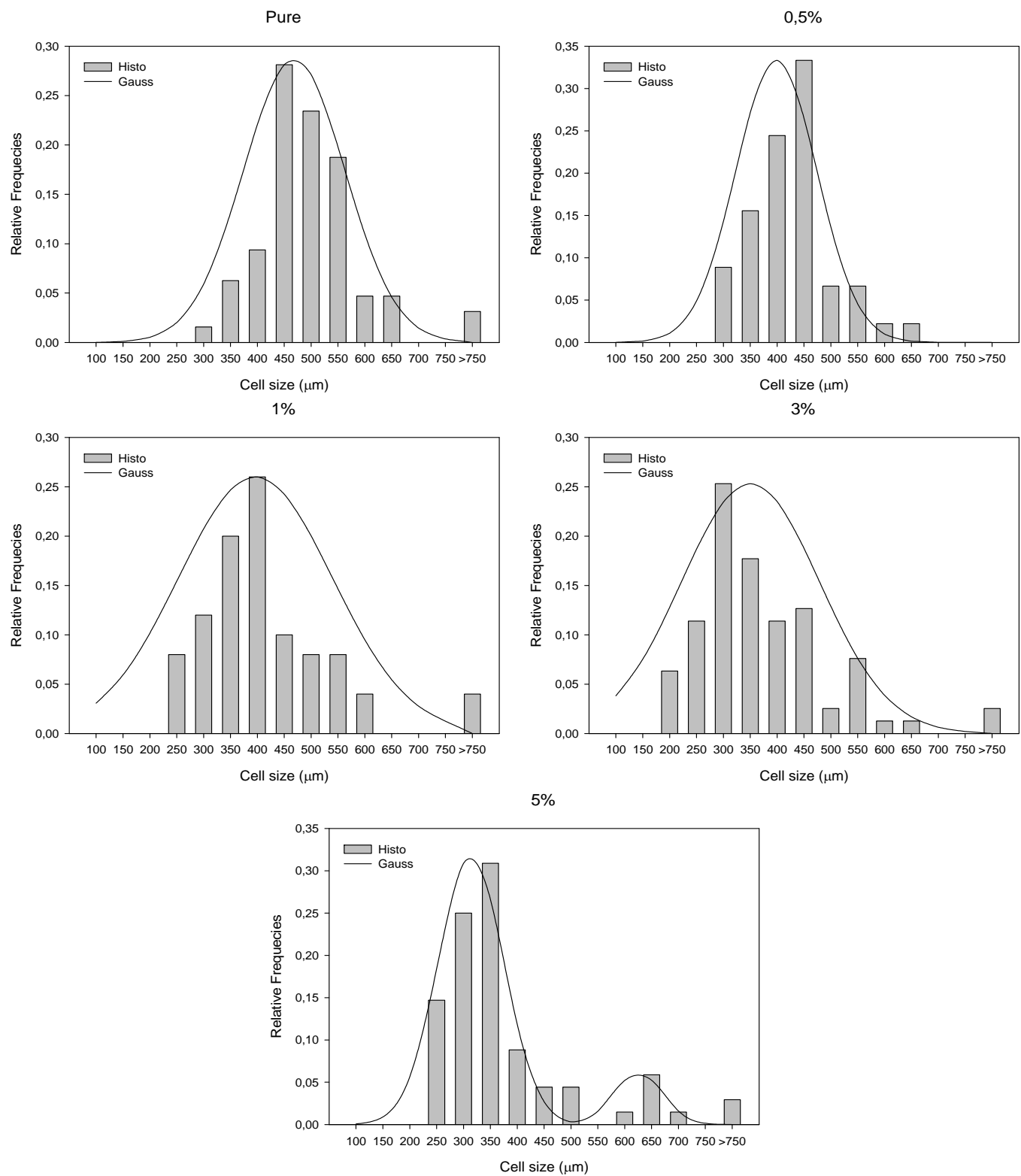

FIGURE 5.2 Cell size distributions : Pure material and materials containing different nanoclays concentrations

Analysis of SEM images provides quantitative information, which can be observed in Figures 5.2 and 5.3. Figure 5.2 shows the cell size distribution of the different materials in a plane containing the growing direction. It is easy to corroborate the qualitative observations 
previously mentioned. The inclusion of nanoclays produces a reduction of the average cell size (figure 3 shows this trend). In addition, a Gaussian fitting of the data allows observing a wider cell size distribution as the amount of nanoclays is increased. Even for the higher nanoclays concentration (5\%) a double population of cells is detected.

The reason for this cell size reduction could be related with the nucleation effect of the nanoclays, already mentioned in Chapter 4. Nucleating effect is the consequence of a reduction of surface energy by the inclusion of particles that allows the creation of additional cells. This is a phenomenon that could also explain the double population of cells. This possible explanation, also introduced in Chapter 4, is that there are two nucleation mechanisms: the standard nucleation, which occurs in the polyurethane without nanoclays, and the nanoparticles nucleation, which is produced by the presence of nanoparticles. If both nucleations do not occur at the same time, the cell growth will be different and a double population of cells will appear.

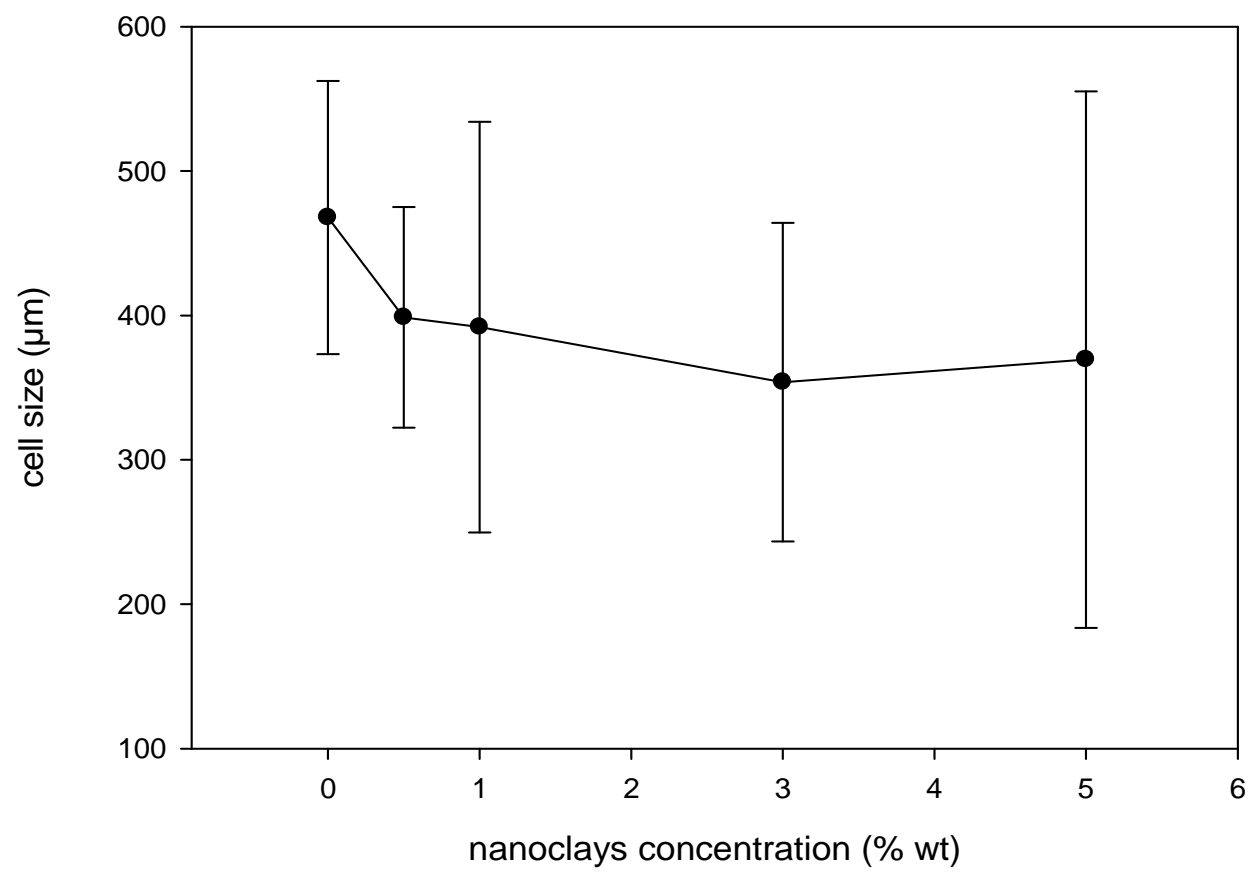

FIGURE 5.3 Average cell sizes for the materials under study

Another effect that can be observed is that the reduction of the cell size showed in Fig. 5.3 does not imply a remarkable change in density. In fact cell size change by around $24 \%$ but density is only modified by $4 \%$. This could be a consequence of two simultaneous effects: filler 
Chapter 5: Nanoclays Concentration Effects

could act as nucleating agent for the cells, and stabilizer of the cell walls. The effect of nanoclays as cell walls stabilizer could reduce coalescence, promoting a higher cell density and lower cell size. Anyway, a recent study on the same system has shown that the principal role of nanoclays in this system is as nucleating agent ${ }^{6}$.

TABLE 5.2 Main cell characteristics of the manufactured materials

\begin{tabular}{|c|c|c|c|c|c|c|c|c|}
\hline $\begin{array}{c}\text { Sample } \\
\text { (nanoclays } \\
\text { concentration } \\
\text { \%wt.) }\end{array}$ & $\begin{array}{l}\text { Cell } \\
\text { size } \\
(\mu \mathrm{m})\end{array}$ & $\begin{array}{c}\text { Cell } \\
\text { anisotropy } \\
\mathrm{R}(\mathrm{x} / \mathrm{y})\end{array}$ & $\begin{array}{c}\text { Asymmetry } \\
\text { coefficient } \\
\text { (AC) }\end{array}$ & NSD & $\begin{array}{l}\text { Cell density } \\
\left(\mathrm{n}-\mathrm{c} \text { cells } / \mathrm{m}^{3}\right)\end{array}$ & $\begin{array}{l}\text { Open cell } \\
\text { content } \\
(\%)\end{array}$ & $\mathrm{f}_{\mathrm{s}}{ }^{7}$ & $\begin{array}{l}\text { Reduction } \\
\text { of cell size } \\
\text { respect } \\
\text { pure } \\
\text { material } \\
(\%)\end{array}$ \\
\hline 0 & 468 & 1,69 & 1,33 & 0,20 & $1,78 \times 10^{10}$ & 6,65 & 0,67 & - \\
\hline 0,5 & 399 & 1,31 & 0,78 & 0,19 & $2,87 \times 10^{10}$ & 6,50 & 0,62 & 14,76 \\
\hline 1 & 392 & 1,12 & 2,35 & 0,36 & $3,11 \times 10^{10}$ & 8,24 & 0,66 & 16,22 \\
\hline 3 & 354 & 1,40 & 1,94 & 0,35 & $4,1 \times 10^{10}$ & 8,52 & 0,78 & 24,36 \\
\hline 5 & 369 & 1,04 & 4,93 & 0,62 & $3,71 \times 10^{10}$ & 8,30 & 0,76 & 21,03 \\
\hline
\end{tabular}

Table 5.2 shows the values of cell size, cell anisotropy, asymmetry coefficient, NSD, cell density, open cell content and mass fraction in the struts $\left(f_{s}{ }^{7}\right)$. As it was previously mentioned, a cell size reduction is observed with the increase in the amount of nanoclays, with a maximum reduction for $3 w t \%$ nanoclays concentration (around $24 \%$ reduction). The anisotropy data confirms SEM images observations. As the amount of clays is increased the cellular anisotropy decreases (with the exception of the material with $3 \%$ of nanoclays). This behaviour could be also related with a possible slow down in the polymerization process that will be discussed again below, and with the increase in the viscosity due to nanoclays addition, which produces low elongation and stretching of foam cells in the rise direction, reducing the cell anisotropy ${ }^{8}$. Asymmetry coefficient presents variations with the amount of clays: a slight reduction for small amounts and a clear increase for the higher concentrations which is a consequence of the presence of a bimodal cell size distribution. NSD values show an increase with the amount of nanoclays added. The high value of NSD for $5 \%$ wt nanoclays concentration also corresponds to a possible bimodal distribution, as it has been shown in Figure 5.2. Cell density presents a clear increase with the nanoclays presence: even a $60 \%$ increase with respect to the 
pure material for the lower concentration, reaching a maximum increase for $3 \%$ concentration with a $130 \%$ increase in this specific characteristic. Open cell content of the samples shows a small increase with the addition of nanoclays, but unlike cell size observations, this variation is observed for concentration of nanoclays of $1 \%$ or higher. The effect of nanoclays as cell opener is perfectly expectable from other studies ${ }^{9,10}$.

Finally, the addition of clays increases the mass fraction in the struts for clays content above $3 \%$ by weight. This effect could be related with the fact that the presence of nanoclays could slow down the polymerization process ${ }^{11}$ permitting on the one hand an easier bubble reaccommodation (and thus reducing anisotropy) and on the other hand, due to the longer time between blowing and gelling reactions, giving more time to capillary forces to enhance drainage in the cell walls and then increasing the strut volumetric fraction. This change in the kinetics of foams has been analysed by using FTIR (see section 3.2.7 for the experimental details) and the results are showed in Fig. 5.4 and Table 5.4.

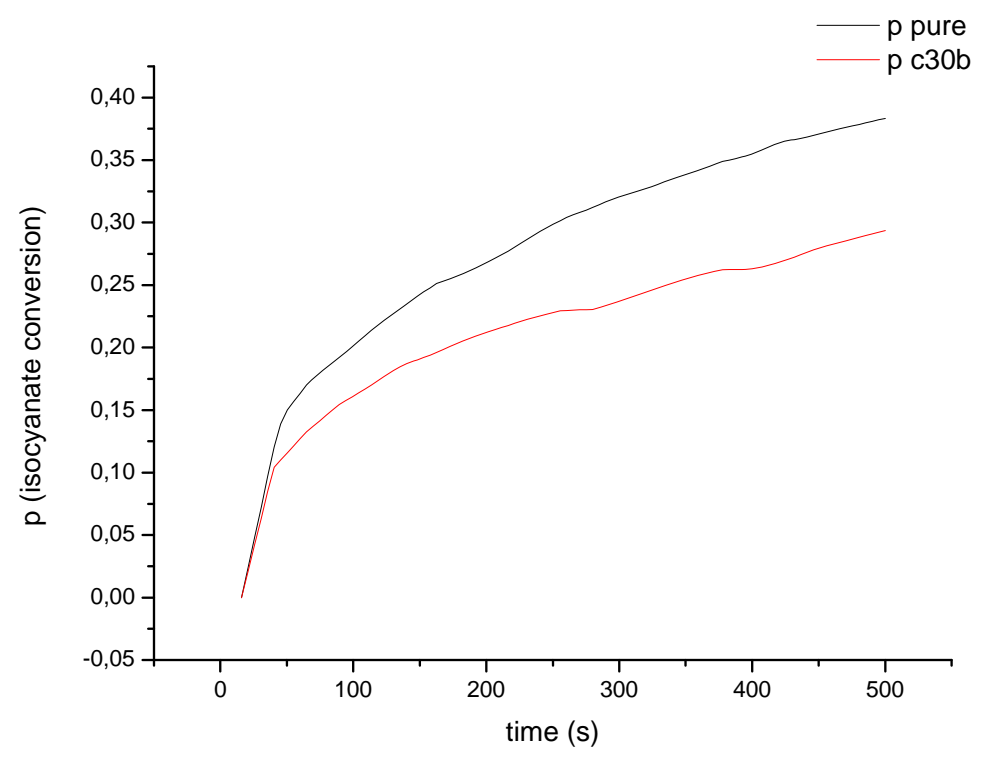

FIGURE 5.4.- Isocyanate conversión for Pure PU and 3wt\% C30B infused PU

Figure 5.4 shows the results of a study over the isocyanate conversion, obtained from a FTIR study of the polymerization reaction. Although the polyurethane employed in this study is different from the one employed in the present PhD work, results are applicable due to the similitude between the composition and final densities of both formulations. The isocyanate conversion data was calculated using the equation: 
Chapter 5: Nanoclays Concentration Effects

$$
p_{N C O}=1-\frac{A_{N C O}}{A_{0}}
$$

where $A_{N C O}$ indicates the area under the characteristic isocyanate peak in the FTIR spectra (located at $2270 \mathrm{~cm}^{-111}$ ) and $A_{0}$ is the value of this peak at the initial stage of polymerization. In the time evolution of the isocyanate conversion it is possible to observe a lower degree of conversion for a given time with the inclusion of nanoclays.

Furthermore, conversion data can be fitted to different kinetics orders ( $n$ ):

$$
\begin{array}{ll}
n=1 & \ln (1-p)=-k_{0} t+C \\
n=2 & \frac{1}{(1-p)}=k_{0} t+C \\
n=3 & \frac{1}{(1-p)^{2}}=-k_{0} t+C
\end{array}
$$

where $\mathrm{p}$ is the isocyanate conversion, $\mathrm{k}_{0}$ is the kinetic constant, $\mathrm{t}$ is the time value and $\mathrm{C}$ is an integration constant. Table 5.3 shows the fitting of the data of Figure 5.4 to the different

\begin{tabular}{|c|c|c|c|c|c|c|}
\hline \multirow[t]{2}{*}{ Sample } & \multicolumn{2}{|c|}{$1^{\text {st }}$ order } & \multicolumn{2}{|c|}{$2^{\text {nd }}$ order } & \multicolumn{2}{|c|}{$3^{\text {rd }}$ order } \\
\hline & $k$ & $r^{2}$ & $k$ & $r^{2}$ & $\kappa$ & $r^{2}$ \\
\hline Neat & $7,73 E-04$ & 0,9242 & $1,06 \mathrm{E}-03$ & 0,9553 & $2,92 \mathrm{E}-03$ & 0,9773 \\
\hline С $30 \mathrm{~B}$ & $5,05 E-04$ & 0,8936 & $6,32 \mathrm{E}-04$ & 0,9212 & $1,59 \mathrm{E}-03$ & 0,9439 \\
\hline
\end{tabular}
kinetics equations. It is observed a clear reduction of the kinetic constant for all the fitting equations, as a consequence of the nanoclays inclusion.

TABLE 5.3.- Different order kinetics for Pure PU and 3wt\% C30B infused PU.

This reduction of the polyurethane chemical reaction rate with the inclusion of nanoparticles has been also studied in previous publications ${ }^{12,13}$, and it has been related not only with the increase of the viscosity due to the nanoparticles presence, but also with a possible interaction of nanoparticles functionalization and tin catalyst. 
Table 5.4 shows the cell density increase by the nanoclays addition. As it was previously discussed an increase of the cell density is observed when clays concentration is increased.

TABLE 5.4 Nucleation features of the manufactured materials

\begin{tabular}{|c|c|c|c|c|}
\hline $\begin{array}{c}\text { Sample } \\
\text { (nanoclays } \\
\text { concentration \%wt.) }\end{array}$ & $\begin{array}{l}\text { Cell density } \\
\left(\mathrm{n}-\mathrm{cell} s / \mathrm{m}^{3} \text { ) }\right.\end{array}$ & $\begin{array}{c}\text { Cell density } \\
\text { increase (\% respect } \\
\text { pure material) }\end{array}$ & $\begin{array}{c}\text { Potential nucleant } \\
\text { density } \\
\text { (nucleants } / \mathrm{m}^{3} \text { ) }\end{array}$ & $\begin{array}{c}\text { Nucleation } \\
\text { efficiency (\%) }\end{array}$ \\
\hline 0 & $1,78 \times 10^{10}$ & - & - & - \\
\hline 0.5 & $2,87 \times 10^{10}$ & 61,24 & $2,53 \times 10^{15}$ & $1.19 \times 10^{-5}$ \\
\hline 1 & $3,11 \times 10^{10}$ & 74,72 & $5,05 \times 10^{15}$ & $5.94 \times 10^{-6}$ \\
\hline 3 & $4,1 \times 10^{10}$ & 130,34 & $1,52 \times 10^{16}$ & $1.98 \times 10^{-6}$ \\
\hline 5 & $3,71 \times 10^{10}$ & 108,43 & $2,53 \times 10^{16}$ & $1.19 \times 10^{-6}$ \\
\hline
\end{tabular}

To study this variation, the potential nucleant density in a heterogeneous nucleation system was estimated using the equation ${ }^{14}$ :

$$
\frac{\text { Nucleants }}{m^{3}}=\frac{w}{\rho_{N}} \frac{\rho_{\text {blend }}}{V_{P}}
$$

where $w$ is the weight fraction of nanoparticles in the composite, $\rho_{N}$ is the density of the nanoclays, $\rho_{\text {blend }}$ is the density of the polymer blend and $V_{p}$ is the volume of the individual particle. The assumptions for these calculations were the same than for the ones showed in Chapter 4. This estimation of the number of nucleants per $\mathrm{cm}^{3}$ is presented in table 5.5 along with the nucleation efficiency, defined by the ratio of the measured cell density to the potential nucleant density. As the amount of nanoclays is increased, the nucleation efficiency decreases. This could be due to a worse dispersion of nanoclays when their amount is increased. Again, results show low nucleation efficiency, but similar to those obtained in the previous chapter, and as it was explained in that chapter they indicate a poor efficiency of clays as nucleating sites for this particular system. 
Chapter 5: Nanoclays Concentration Effects

\subsubsection{SAXS}

SAXS patterns present in Fig. 5.5 allow obtaining information about the intercalation/exfoliation of clays in the different systems with different clays concentration. In this graph, it is also possible to observe the results for the pure material and the pure nanoclays. As it was presented in the previous chapter, for the pure nanoclays it is detected the characteristic diffraction peak due to the lamellar structure of the nanoclays, for a $2 \theta$ value close to 4.7 degrees. According to Bragg equation presented in Chapter 3 (Eq. 22), it is possible to obtain a value for the inter-lamellar space in Cloisite 30B of $18.8 \AA$, close to the $18.5 \AA$ data supplied by Southern Clay Products, Inc. (See table 3.2)

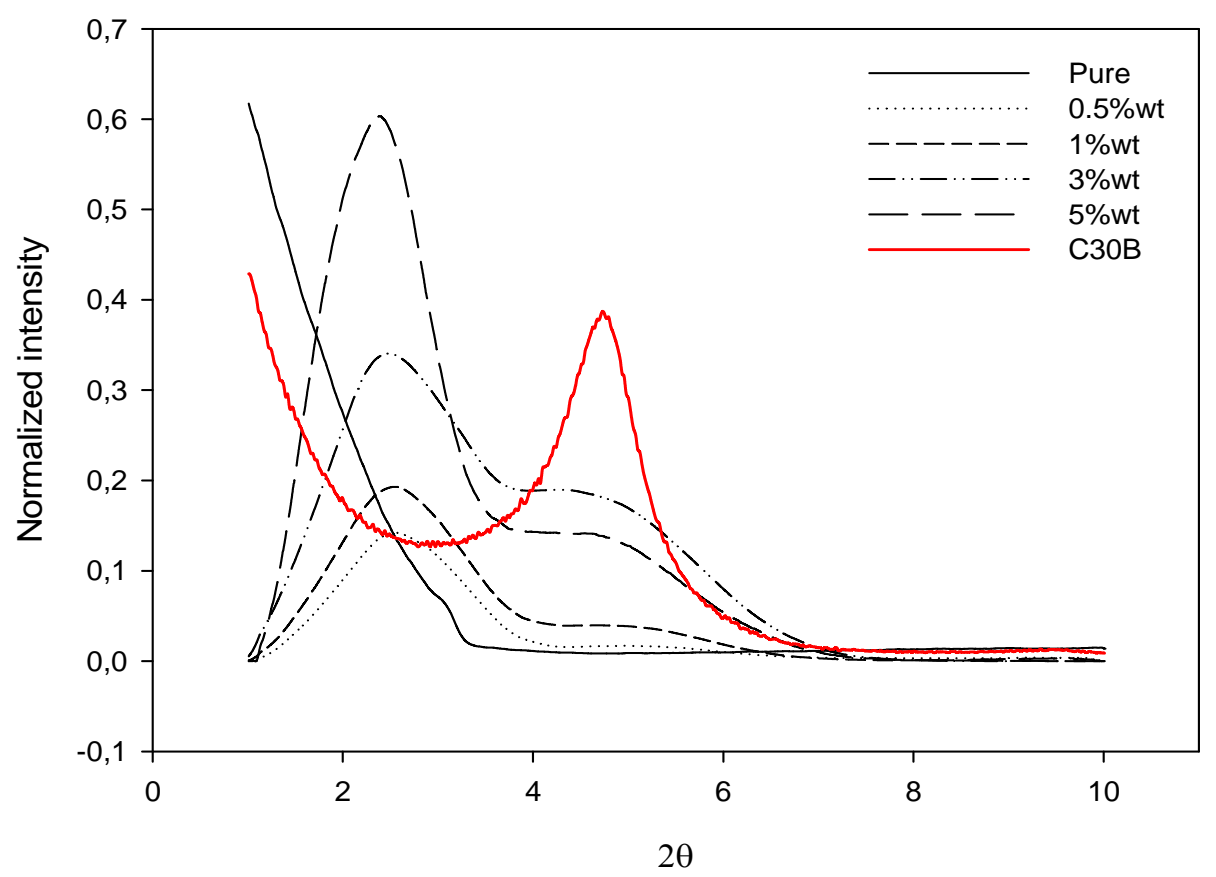

FIGURE 5.5. SAXS patterns for polyurethane foams prepared with different dispersion techniques and for pure Cloisite 30B nanoclays.

The results for the different concentrations show a decrease of this peak, and an increase in its width, together with the presence of a higher peak at around $2.2^{\circ}$. The variations in the peaks intensities can be explained by the differences in the nanoclays concentrations. In the case of the $5 \%$ wt concentration, a small shifting to lower angles (that implies an increase in the inter-lamellar space) has been observed. The increase in the width of the peak at $4.7^{\circ}$ and the presence of a new peak at $2.2^{\circ}$ confirms the intercalation of the 
nanoclays, independently form the nanoclays concentration. On the other hand, the results clearly show that the clays are not exfoliated by any of the mixing processes used.

\subsubsection{Macroscopic characterization}

\subsubsection{Mechanical properties: compression, bending and shear}

Figure 5.6.a and 5.6.b show examples of the compression and bending experiments respectively, where different slopes and compression/bending stresses can be observed for the different nanoclays concentrations.

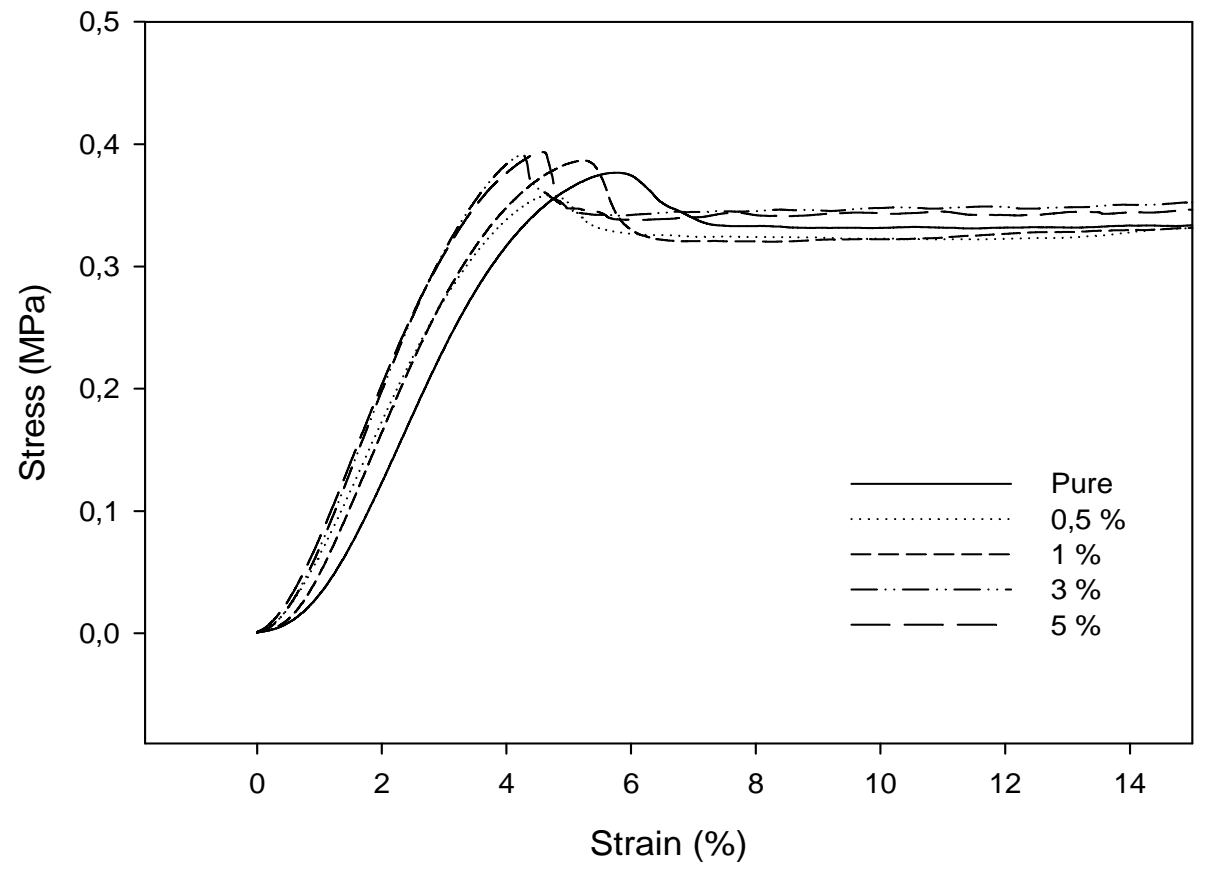

(a) 


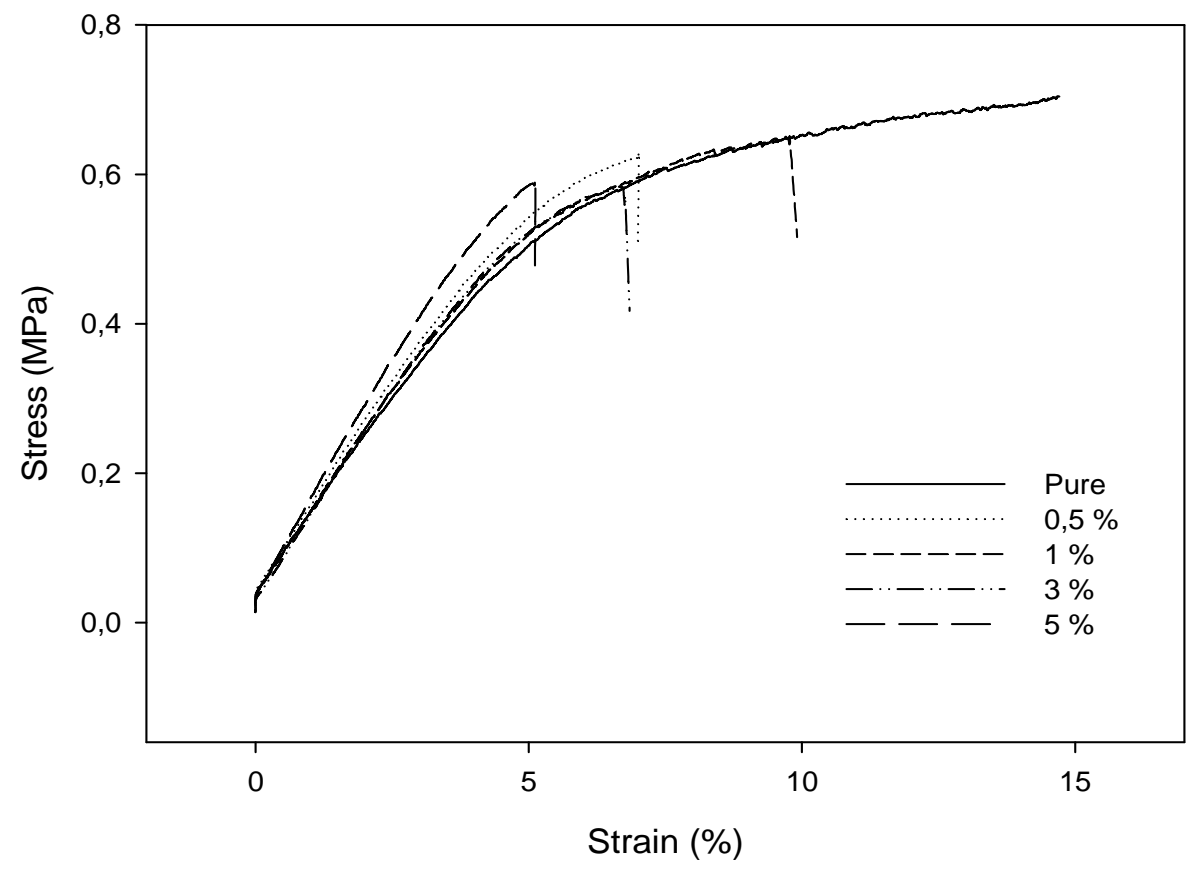

(b)

FIGURE 5.6. Stress-strain curves for the different materials: (a) Compression mode; (b) Bending mode.

These results are summarized in Tables 5.5 and 5.6. It is possible, for the compression properties, to detect an improvement of the Elastic Modulus of the foams with the inclusion of nanoclays, with a maximum (around a $20 \%$ improvement) for $3 \mathrm{wt} \%$ concentration. Collapse strength also shows a similar improvement with the nanofillers percentage variation, but in this case the improvement is near $5 \%$ for a $5 \mathrm{wt} \%$ of nanoclays.

Flexural modulus presents a small increase with the presence of nanoclays, similar for all the percentages of material except for the 5\%, which present a higher value (around $11 \%$ higher than pure material). Deformation at maximum strength presents a clear reduction as the amount of nanoclays added is increased; this is especially significant for clay contents over $3 \%$. Flexural strength presents a slight decrease with respect to pure material for all nanoclays concentrations. 
TABLE 5.5. Compressive mechanical properties for the manufactured materials

\begin{tabular}{ccccc}
\hline Material & $\begin{array}{c}\text { Elastic } \\
\text { Modulus } \\
\text { (MPa) }\end{array}$ & $\begin{array}{c}\text { Standard } \\
\text { Deviation } \\
(\mathrm{MPa})\end{array}$ & $\begin{array}{c}\text { Collapse } \\
\text { Strength (MPa) }\end{array}$ & $\begin{array}{c}\text { Standard } \\
\text { Deviation } \\
\text { (MPa) }\end{array}$ \\
\hline Pure & 10,73 & 0,47 & 0,35 & 0,04 \\
\hline $1 \%$ & 10,99 & 0,11 & 0,33 & 0,04 \\
$3 \%$ & 11,70 & 0,16 & 0,34 & 0,07 \\
$5 \%$ & 12,85 & 0,13 & 0,38 & 0,02 \\
\hline 12,16 & 0,21 & 0,37 & 0,04 \\
\hline
\end{tabular}

TABLE 5.6. Flexural mechanical properties for the manufactured materials

\begin{tabular}{|c|c|c|c|c|c|c|}
\hline Material & $\begin{array}{l}\text { Flexural } \\
\text { modulus } \\
\text { (MPa) }\end{array}$ & $\begin{array}{l}\text { Standard } \\
\text { Deviation } \\
\text { (MPa) }\end{array}$ & $\begin{array}{c}\text { Deformation at } \\
\text { maximum strength } \\
\text { (\%) }\end{array}$ & $\begin{array}{c}\text { Standard } \\
\text { Deviation } \\
\text { (\%) }\end{array}$ & $\begin{array}{l}\text { Flexural } \\
\text { strength } \\
(\mathrm{MPa})\end{array}$ & $\begin{array}{c}\text { Standard } \\
\text { Deviation } \\
\text { (MPa) }\end{array}$ \\
\hline Pure & 10,64 & 0,98 & 13,98 & 0,98 & 0,73 & 0,04 \\
\hline $0.5 \%$ & 10,53 & 0,35 & 10,06 & 7,12 & 0,65 & 0,04 \\
\hline $1 \%$ & 10,17 & 0,33 & 10,50 & 1,14 & 0,65 & 0,01 \\
\hline $3 \%$ & 10,62 & 0,22 & 6,66 & 2,28 & 0,58 & 0,01 \\
\hline $5 \%$ & 11,84 & 0,29 & 6,18 & 1,57 & 0,63 & 0,05 \\
\hline
\end{tabular}

Taking into account that there is also some variation in densities due to the nanofillers addition, the previous comparisons are not precise enough as long as foams with different densities are compared. In order to compare the properties of materials with different densities, the values of Elastic Modulus, Collapse Strength, Flexural Modulus and Flexural Strength were normalized by the square of the density (Figure 5.7, Figure 5.8, Figure 5.9 and Figure 5.10), considering the Gibson and Ashby relationship between properties and density in foams ${ }^{15}$ (equation 2 of chapter 4 ). 


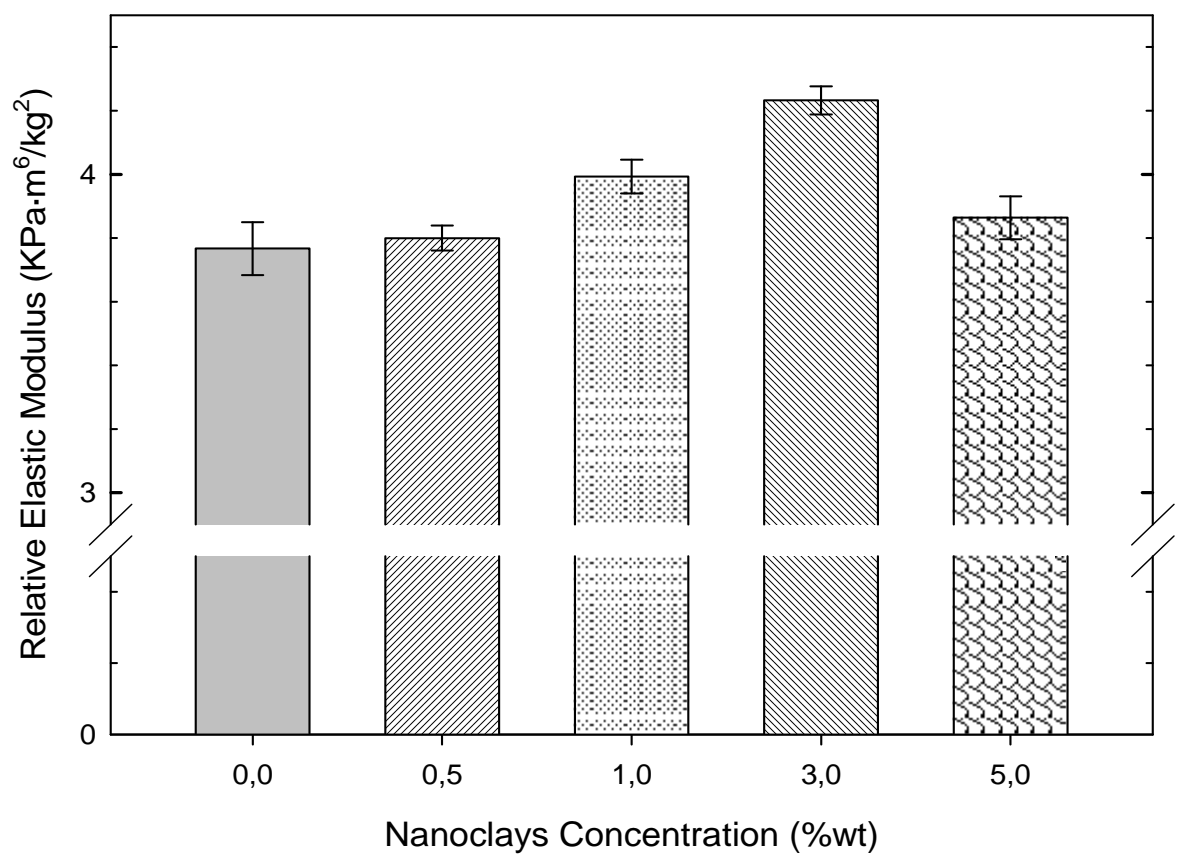

FIGURE 5.7 Elastic Modulus divided by the square of density, as function of clays concentration

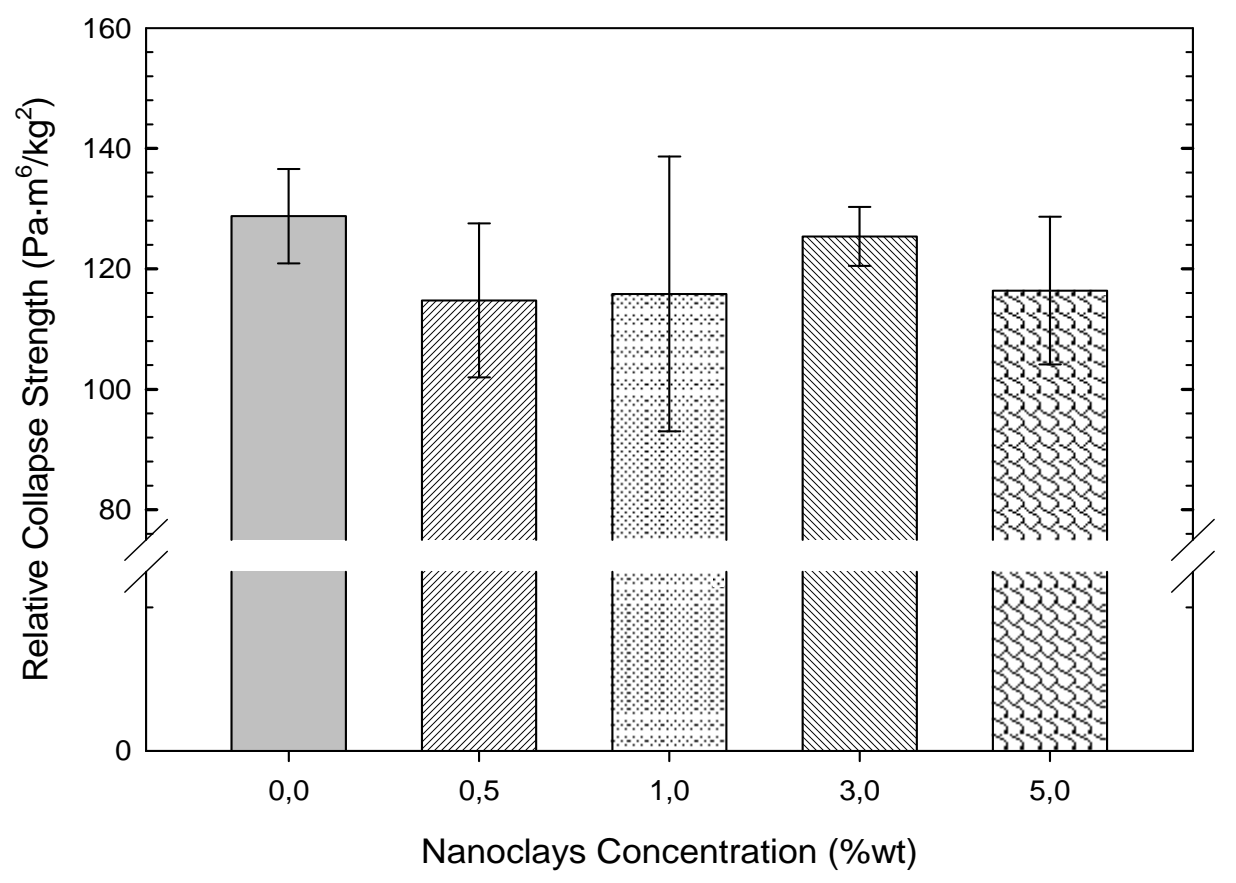

FIGURE 5.8 Collapse Strength divided by the square of density, as function of clays concentration 


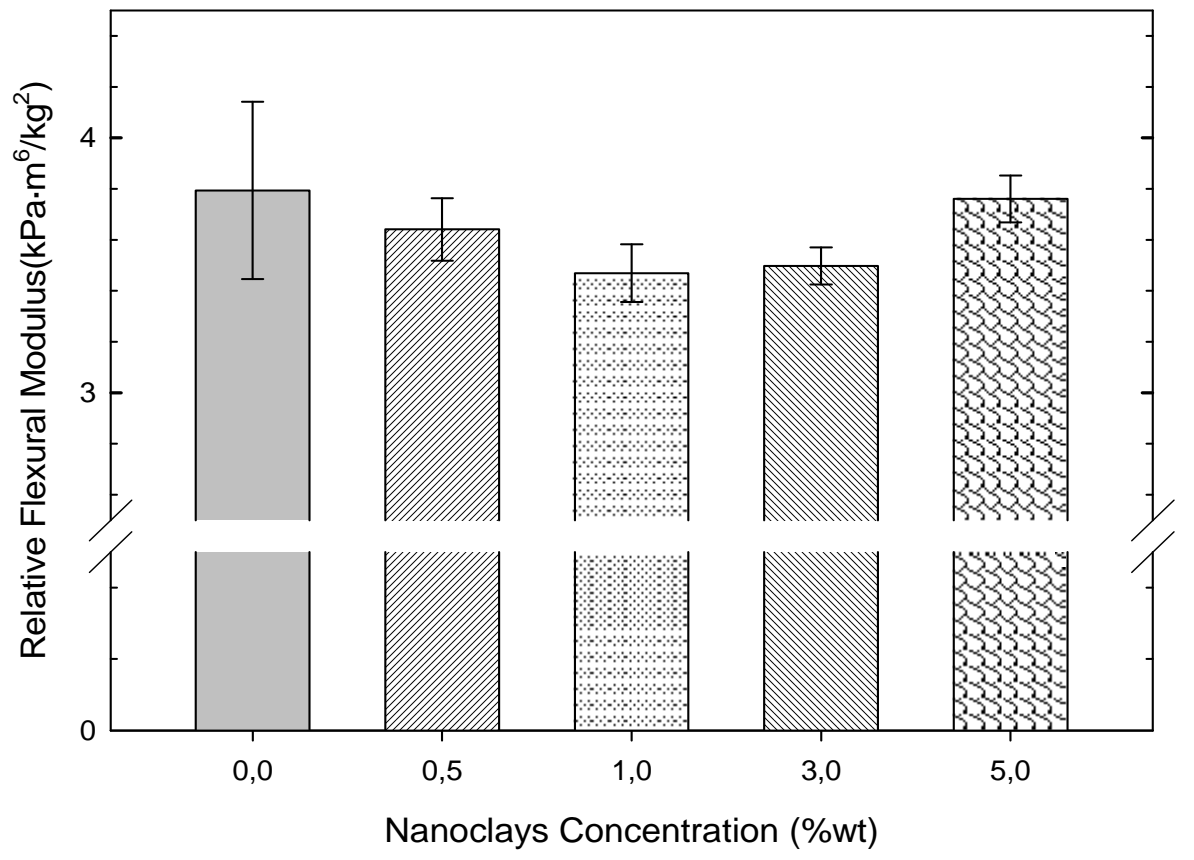

FIGURE 5.9 Flexural Modulus divided by the square of density, as function of clays concentration

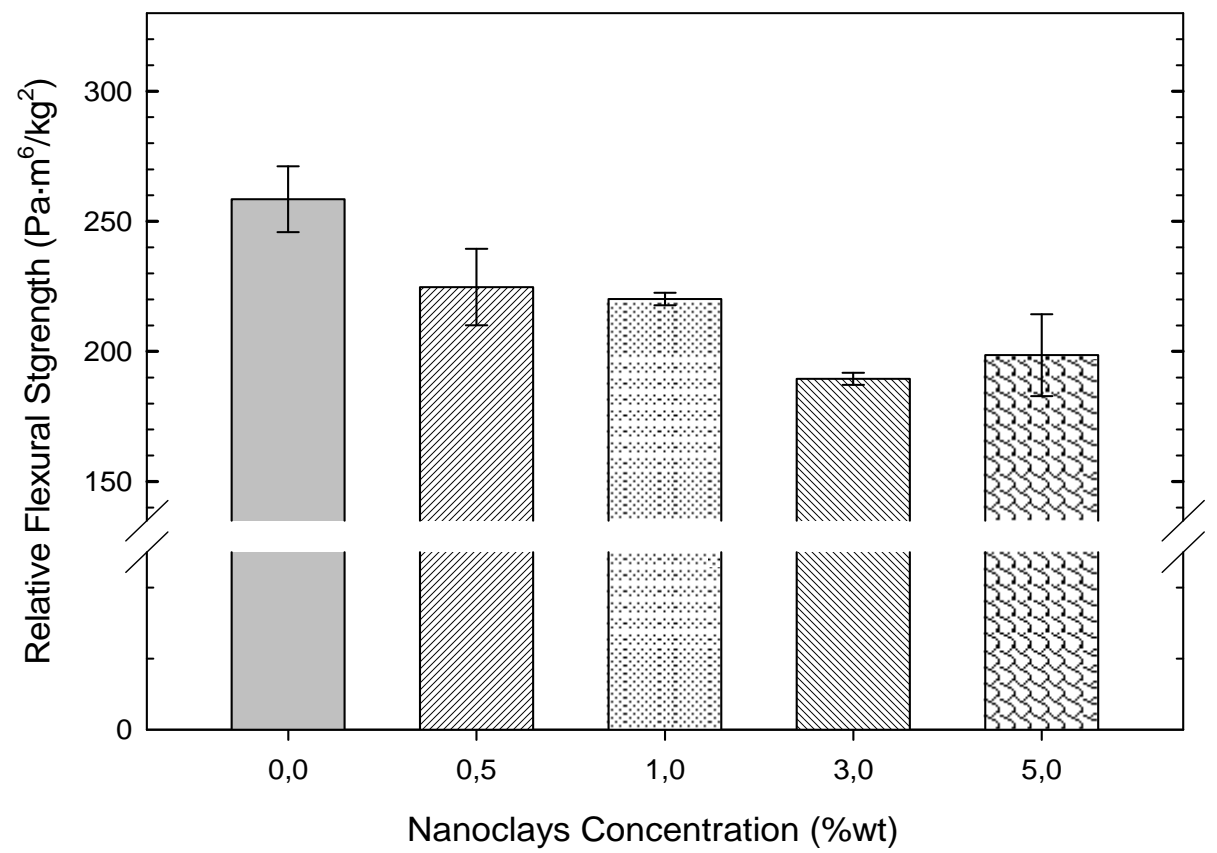

FIGURE 5.10 Flexural Strength divided by the square of density, as function of clays concentration 
A clear increase with the addition of nanoclays was observed for the relative Young's modulus, but it was not correlated with the amount of nanoclays added. Instead of this, best result was obtained for the $3 \mathrm{wt} \%$ nanoclays value, $(12.3 \%$ of increase with respect to pure material). For $5 \mathrm{wt} \%$ nanoclays addition, results decreased to similar values than those obtained for 1 wt\% nanoclays.

Relative collapse strength presents a smooth decrease in comparison with the pure material. This decrease is slightly higher as nanoclays concentration is increased. Decrease with respect to the pure material goes from $1 \%$ to $5 \%$ approximately.

Relative flexural modulus presents a slight reduction with the addition of nanoclays with a minimum for $1 \mathrm{wt} \%$ nanoclays (around $8 \%$ reduction respect pure material) and similar results for $5 \mathrm{wt} \%$ nanoclays. Anyway, these must be considered taking into account the decrease of the deformation at maximum strength: the final material presents better modulus but with a decrease in deformation capabilities.

Relative flexural strength presents a considerable decrease with the increase of the amount of nanoclays, with a minimum value for $3 \%$ (around $27 \%$ of decrease respect pure material), and then experiments a small recuperation for $5 \mathrm{wt} \%$ of nanoclays concentration ( $23 \%$ of decrease respect pure material), but with values even distant from the $0.5 \mathrm{wt} \%$ concentration ( $13 \%$ of reduction respect pure material, lowest value for nanoclays infused materials).

TABLE 5.7.- Shear modulus results for the plane perpendicular to foaming direction ( $x$-direction) and for the plane parallel to foaming ( $y$-direction) direction

\begin{tabular}{|c|c|c|c|c|}
\hline Material & $\mathrm{G}_{\text {x-direction }}(\mathrm{MPa})$ & $\begin{array}{l}\text { Standard deviation } \\
\text { (MPa) }\end{array}$ & $\mathrm{G}_{\mathrm{y} \text {-direction }}(\mathrm{MPa})$ & $\begin{array}{c}\text { Standard } \\
\text { deviation (MPa) }\end{array}$ \\
\hline Pure & 4.7 & 0.2 & 4.1 & 0.2 \\
\hline $0.5 \%$ & 4.7 & 0.4 & 4.1 & 0.2 \\
\hline $1 \%$ & 4.6 & 0.3 & 4.2 & 0.3 \\
\hline $3 \%$ & 4.9 & 0.3 & 4.3 & 0.3 \\
\hline $5 \%$ & 4.7 & 0.2 & 4.2 & 0.2 \\
\hline
\end{tabular}


Shear modulus results for foaming ( $x$-direction) and perpendicular to foaming ( $y$ direction) directions are summarized in Table 5.7. For x-direction, an increase was observed again for the $3 \mathrm{wt} \%$ concentration, while a small decrease was obtained for the $1 \mathrm{wt} \%$ and no variation for the rest of the samples. For $y$-direction similar results were obtained for all the samples. In general it can be concluded that modifications on this property are only marginal. Differences between $\mathrm{x}$ and $\mathrm{y}$-direction results can be related to the cellular anisotropy showed in Table 5.2,

In order to have a better comparison of the material properties, we have used again the scaling law proposed by Gibson \& Ashby ${ }^{15}$ for cellular materials previously used in the case of the compression properties (Eq. 2 of chapter 4). With the help of this relationship it is possible to reduce the influence of the material density in the final mechanical properties. As a result, Fig. 5.11 shows the shear properties relative to the square of the density. This figure shows that there is still a difference between the foaming direction and its perpendicular direction and that shear modulus is not affected by the clays addition.

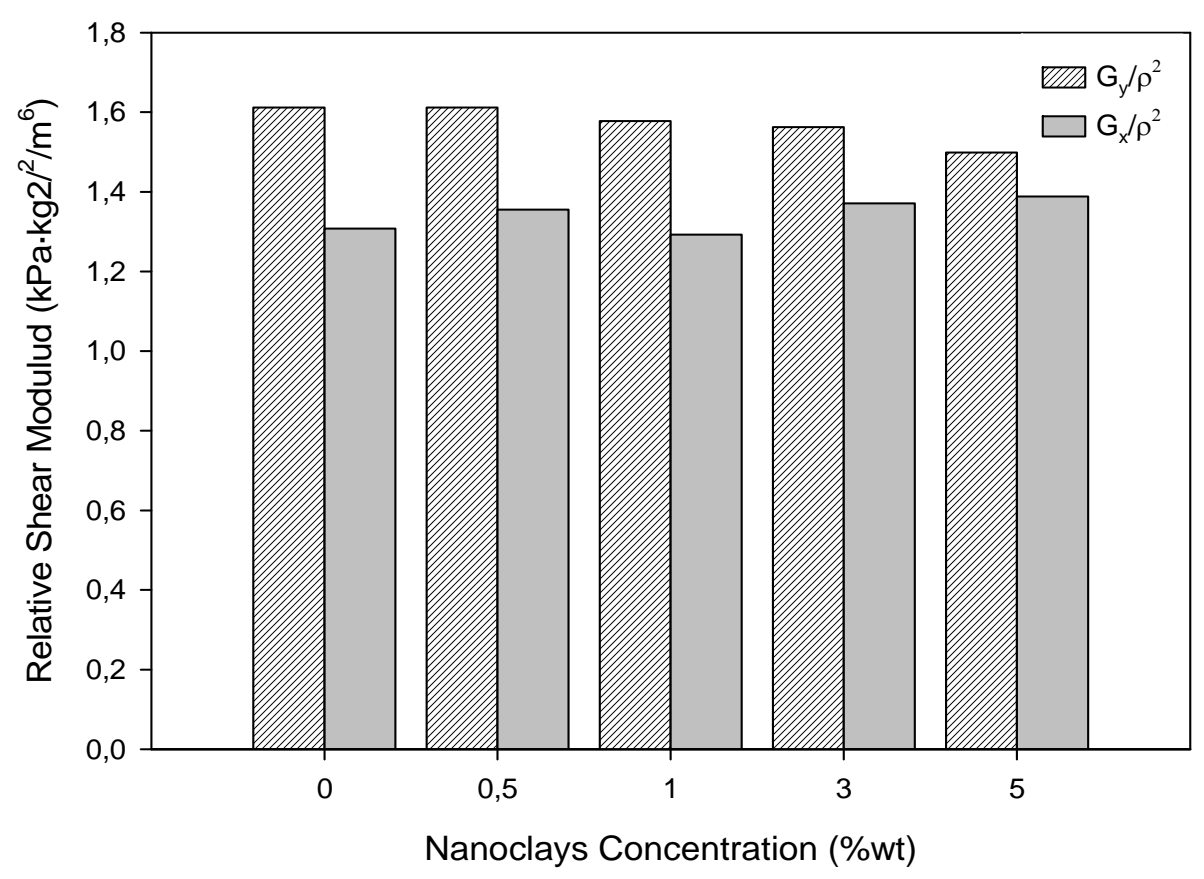

FIGURE 5.11. Shear modulus relative to the square of density for materials containing different ammounts of clays. 


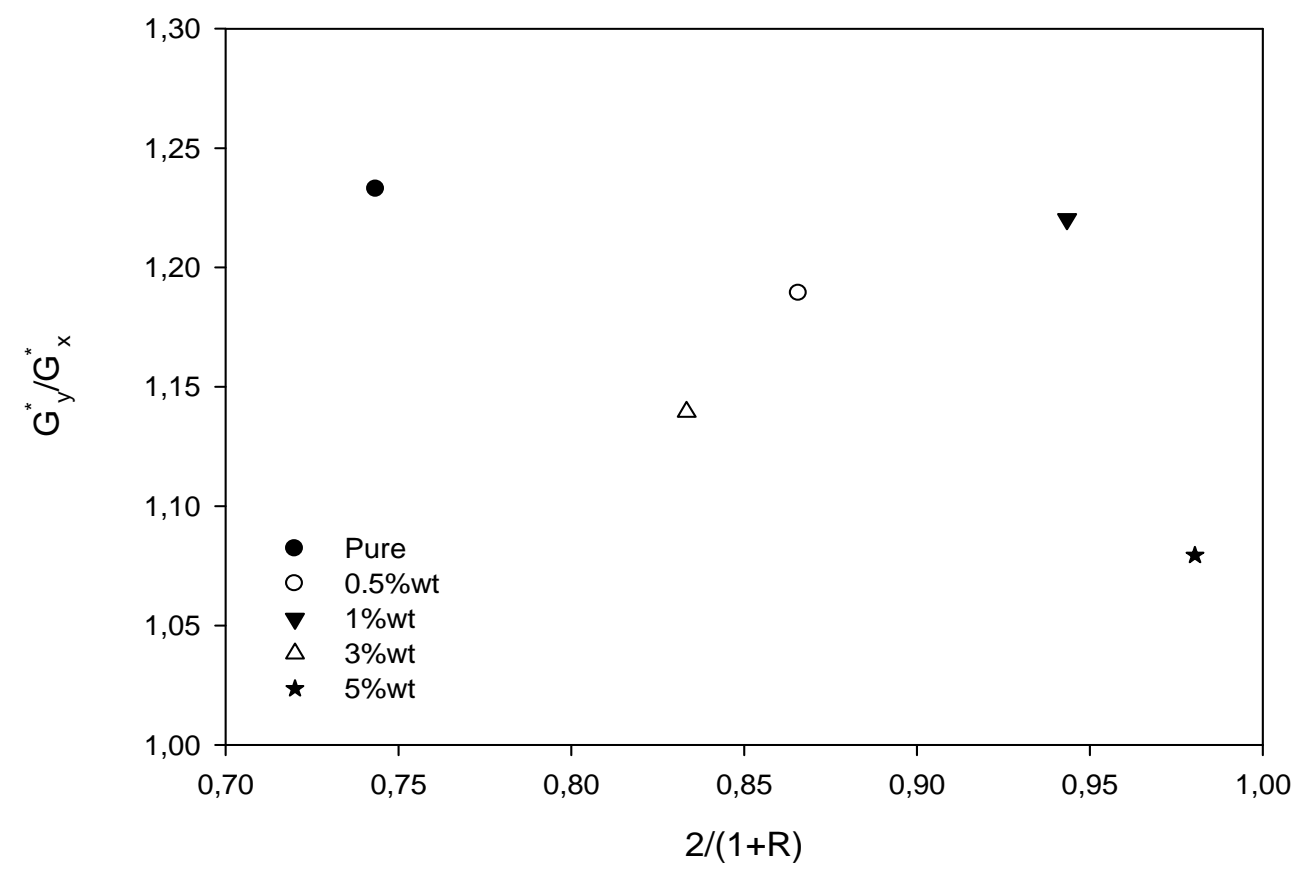

FIGURE 5.12.- Correlation between shear modulus and anisotropy, for the different dispersion techniques

Using a similar procedure to that used in the previous chapter, we have used equation $6^{15,}$ ${ }^{16}$, to analyse the data for the shear modulus:

$$
\frac{G_{y}}{G_{x}}=\frac{2}{1+R}
$$

Where $G_{i}$ is the shear modulus measured in the plane perpendicular to the $i$ direction and $R$ is the anisotropy ratio of the cellular structure.

As all the elements in this equation have been measured during the characterisation of the produced materials, it is possible to establish the correlation showed in Fig. 5.12. A linear trend indicating that an increase in the anisotropy is connected with an increase in the ratio of the shear moduli in two perpendicular planes.

As in the previous chapter we have used Eq. $7^{15}$ to estimate Piosson's ratio:

$$
G_{i}=\frac{E_{i}}{2\left(1+v_{i}\right)}
$$


Where $\mathbf{G}_{\mathbf{i}}$ is the shear modulus in the plane perpendicular to the $\mathbf{i}$ direction, $\mathbf{E}_{\mathbf{i}}$ the elastic modulus in the $\mathbf{i}$ direction and $\mathbf{v}_{\mathbf{i}}$ is the Poisson's ratio relative to this direction, which is the negative ratio of the lateral to the axial strain ${ }^{15}$.

TABLE 5.8. Experimental calculations for Poisson's ratio

\begin{tabular}{cc}
\hline $\begin{array}{c}\text { Nanoclays } \\
\text { concentration (\%) }\end{array}$ & Poisson's ratio \\
$\mathbf{0}$ & 0,141 \\
$\mathbf{0 . 5}$ & 0,169 \\
$\mathbf{1}$ & 0,271 \\
$\mathbf{3}$ & 0,311 \\
$\mathbf{5}$ & 0,293 \\
\hline
\end{tabular}

Table 5.8 shows the calculation of the Poisson's ratio for the different materials analysed. It is possible to observe that there is an increase of the Poisson's ratio when the amount of clays is increased, which should be related with the modification of the cellular structure induced by the clays presence.

The results for the shear modulus indicate that clays do not have a significant influence in this property. The expected reinforcement of the clays is not observed probably because the polymer matrix is weaker when the clays are added (number of $\mathrm{H}$-bonds is reduced) and the cellular structure is more heterogeneous.

\subsubsection{Thermal conductivity}

Three different points of view were used in the thermal conductivity characterization: the conductivity evolution with time, the conductivity evolution with temperature and the conductivity evolution (at $20 \stackrel{\circ}{\circ}$ ) with the amount of nanoclays added. Thereby, time parameter was firstly characterized to study their effects on the thermal conductivity, after that effect of temperature was analysed and finally an in-depth study of the effect of nanoclays concentration on the thermal conductivity was performed. 


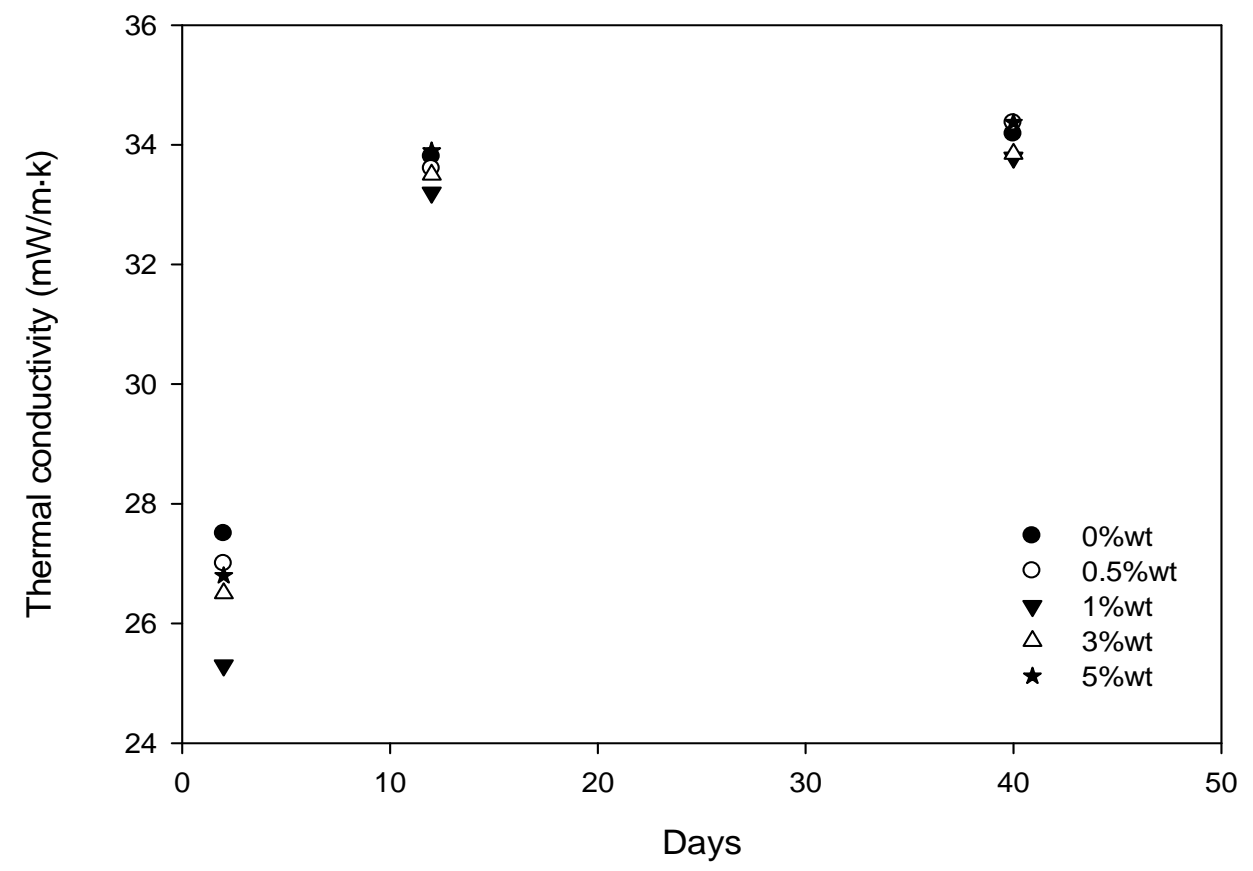

FIGURE 5.13. Thermal conductivity as a function of time for foams with different nanoclays concentration

Time evolution of thermal conductivity can be observed in Fig. 5.13, where the initial value corresponds to experiments performed 2 days after manufacturing, when a significant amount of the blowing agent $\left(\mathrm{CO}_{2}\right)$ was still present inside cells. Other measurements were made 12 days and 40 days after these first measurements. The increase in the thermal conductivity can be explained by the diffusion of the foaming agent $\left(\mathrm{CO}_{2}\right.$; thermal conductivity at $20 \circ \mathrm{C}: 14.5 \mathrm{~mW} \cdot \mathrm{m}^{-1} \cdot \mathrm{k}^{-1}$ ) outwards the foam, and it substitution by atmospheric air, which has a higher thermal conductivity coefficient than $\mathrm{CO}_{2}$ (thermal conductivity at $20 \circ \mathrm{C}: 25.3 \mathrm{~mW} \cdot \mathrm{m}^{-}$ $\left.{ }^{1} \cdot \mathrm{k}^{-1}\right)$. As it will be shown in the prediction of the thermal conductivity section, the contribution of the gas phase has a high weight in the final value of the thermal conductivity (around $70 \%$ of the final value) and small changes in the conductivity of this phase has a clear effect on the final thermal conductivity. Anyway, Figure 5.13 shows that the changes in the thermal conductivity between 12 days and 40 days after manufacturing are really small, so it can be concluded that foaming agent has been completed substituted by air and the foam has reached a stationary state 12 days after production.

The temperature dependence of the thermal conductivity is shown in figure 5.14. These data were obtained at least 12 days after foam production. The thermal conductivity increases linearly with temperature for all the material studied. The parameters of a linear | 168 
fitting for these experimental data are summarised in Table 5.9. The slope of the curve decreases with the amount of nanoclays. As it will be shown later the inclusion of clays promotes an increase of the extinction coefficient, parameter that is directly related with the dependence of radiative term of the thermal conductivity with temperature (see Eq. 8 of Chapter 4)

TABLE 5.9.- Linear fit parameters for the experimental thermal conductivity versus temperature

\begin{tabular}{cccc}
\hline $\begin{array}{r}\text { Sample } \\
\text { (nanoclays\%, } \lambda=A T+B)\end{array}$ & $A\left(\mathrm{mw} / \mathrm{m} \cdot \mathrm{K}^{2}\right)$ & $B(\mathbf{w} / \mathrm{m} \cdot \mathrm{K})$ & $\mathbf{r}^{\mathbf{2}}$ \\
$\mathbf{0}$ & 0.1794 & 30.62 & 0.9781 \\
$\mathbf{0 , 5 0}$ & 0.1703 & 30.74 & 0.9813 \\
$\mathbf{1 , 0 0}$ & 0.1660 & 30.16 & 0.9946 \\
$\mathbf{3 , 0 0}$ & 0.1604 & 30.56 & 0.9932 \\
$\mathbf{5 , 0 0}$ & 0.1581 & 31.05 & 0.9899
\end{tabular}

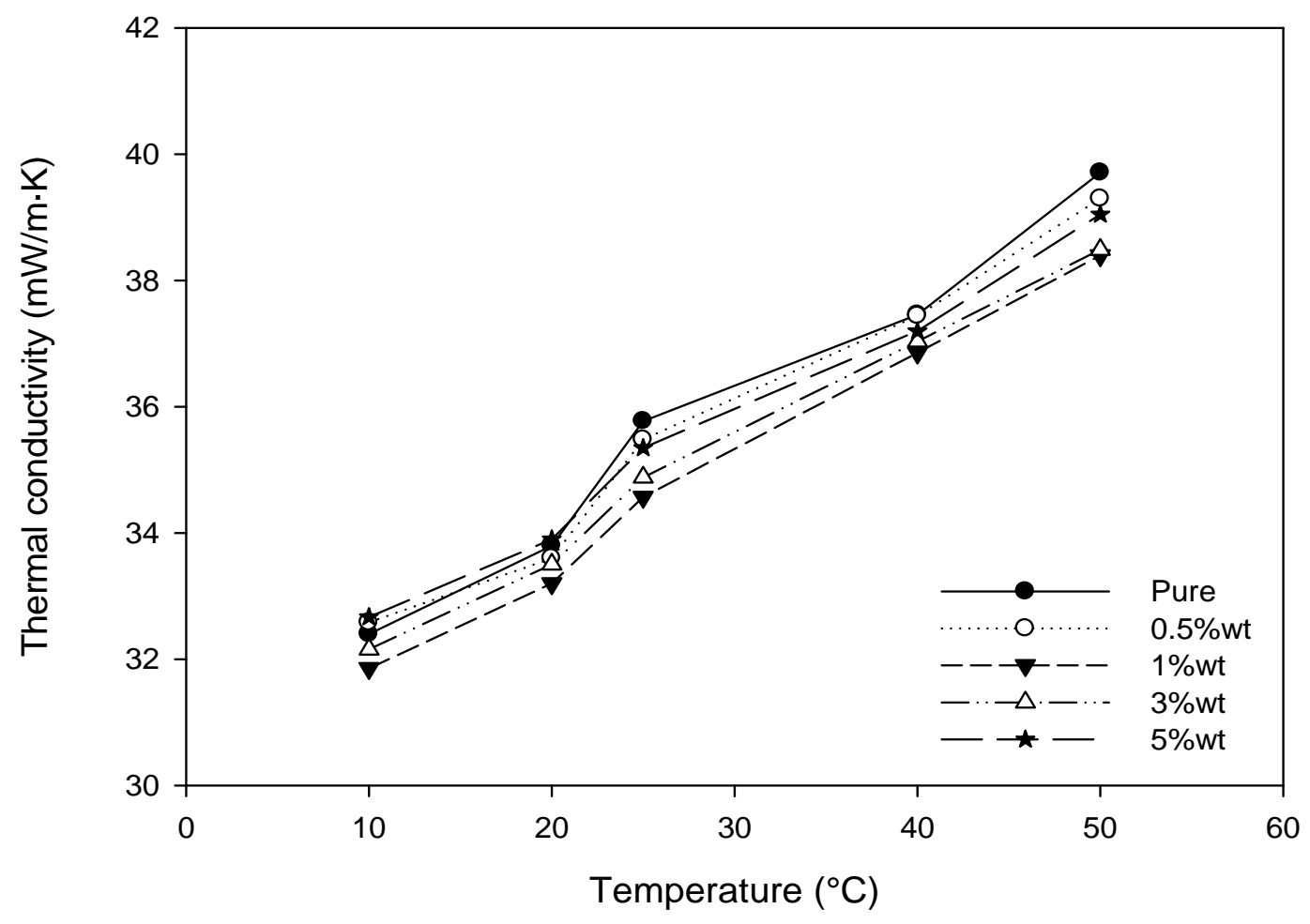

FIGURE 5.14.- Thermal conductivity as a function of temperature 
The evolution of the thermal conductivity with the amount of nanoclays (measured at $20^{\circ} \mathrm{C}$ and for times longer than 40 days after production) can be observed in Figure 5.15.a: a clear decrease of the thermal conductivity by the introduction of nanoclays is observed, with a higher reduction for $1 \%$ nanoclays concentration. Different parameters control the final thermal conductivity of foams; one of them with relative importance is the foam cell size $\mathrm{e}^{17,18}$. Regarding the data of Figure 5.15a and Table 5.2, at least for lower concentrations of nanoclays, it is possible to observe how a reduction of the cell size is in agreement with a reduction of the thermal conductivity. This effect reaches a minimum of thermal conductivity for $1 \%$ of nanoclays, but for higher concentrations the conductivity presents an increase, while the cell size continues its reduction. Others contributions to the thermal conductivity, like the thermal conductivity of the polymer matrix (that can be affected by the inclusion of highs amounts of nanoclays) or changes in the cellular structure at other levels (mass fraction in the struts, open cell content, anisotropy, and so on) can be the origin of this particular behaviour.

a.)

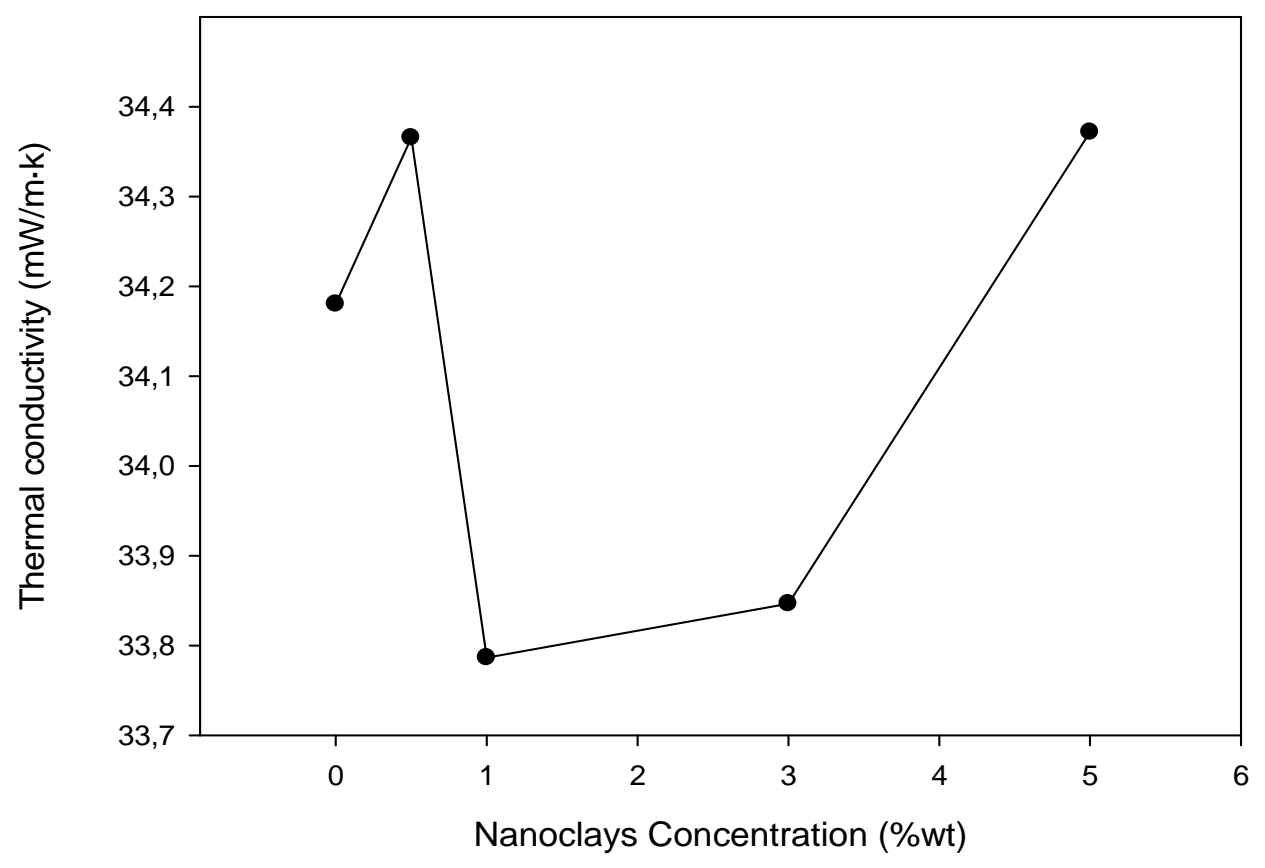

b.) 


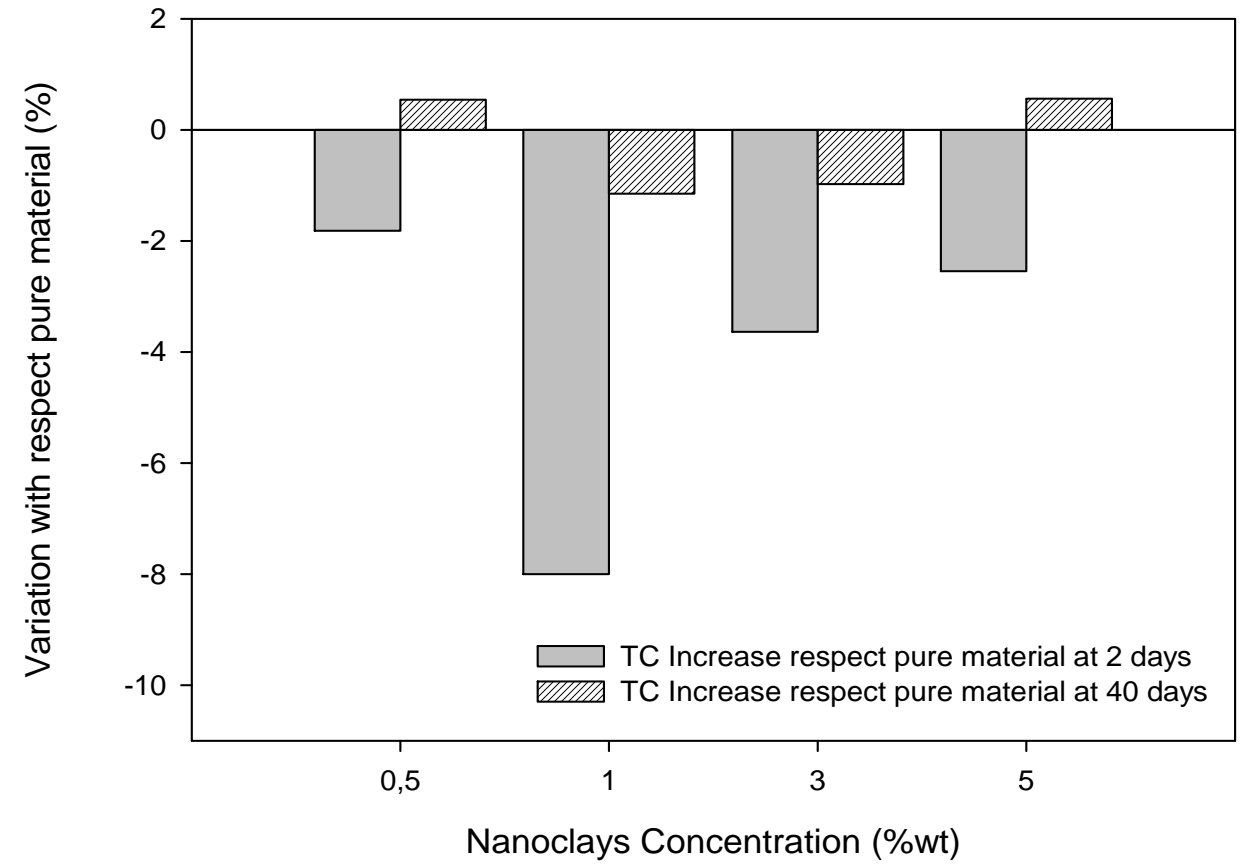

FIGURE 5.15. a.) Thermal conductivity at $20 \circ \mathrm{C}$ as a function of nanoclays concentration, 40 days after manufacturing, b.) Thermal conductivity variation with respect to pure material for the different nanoclays concentration, 2 days and 40 days after manufacturing.

Moreover, the effect of the nanoclays over the thermal conductivity presents a better performance for shorts times after manufacturing: Figure 5.15.b shows how for only two days after foam productions thermal conductivity of $1 \mathrm{wt} \%$ foam present a $8 \%$ reduction with respect to pure material. The lower value of the gas conduction term for short times and as consequence the higher weight of the radiative term explains this result. Anyway, these considerations will be analyzed in detail in the modelling of thermal conductivity section.

\subsubsection{Extinction coefficient}

Different models have been used in the theoretical study of the thermal conductivity of polymeric foams. Several authors have modelled the final foam conductivity from the conductivity of a continuous solid phase and the conductivity of a continuous or discontinuous gas phase ${ }^{16,19-21}$. For this purpose four physical mechanisms have to be taken into account: conduction through the solid phase, conduction through the gas phase, convection and radiation. The extinction coefficient can be used to estimate this last term ${ }^{22}$, and it can be calculated theoretically and also measured in the laboratory. Figure 5.16 shows part of the 
experimental set up employed in the Brunker FTIR device for the extinction coefficient measurement. The experimental method was previously described in Chapter 3 (Section 3.2.6).

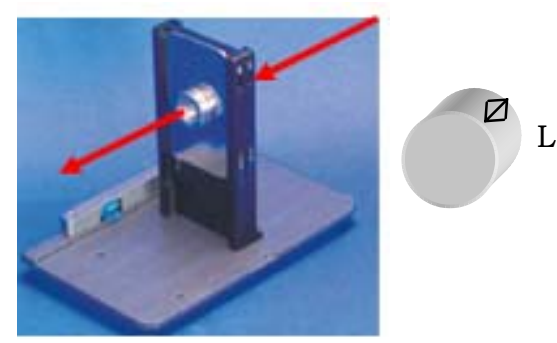

Figure 5.16.- Holder and sample for FTIR measurements

For the application of different theoretical models aiming at predicting the thermal conductivity it is necessary a previous characterisation and data treatment of some properties of the foams. Data such as density, cell size or the amount of material in the struts has been previously obtained. In this section the spectral extinction coefficient will be calculated from experimental data. The spectral extinction coefficient $\left(K_{e, \lambda}\right)$ for thin samples can be obtained by using Beer's law ${ }^{23-28}$ :

$$
\tau_{n, \lambda}=e^{\left(-\int_{0}^{L} K_{e, \lambda} d x\right)}
$$

For homogeneous samples, under the assumption that $K_{e, \lambda}$ is independent of the sample thickness, it is possible to write the following expression:

$$
K_{e, \lambda}=\frac{-\ln \left(\tau_{n, \lambda}\right)}{L}
$$

Where $L$ is the sample thickness, and the transmittance $\left(\tau_{n, \lambda}\right)$ is

$$
\tau_{n, \lambda}=\frac{I_{\lambda}(x)}{I_{0, \lambda}}
$$

With $I_{0, \lambda}$ as the background spectra and $I_{\lambda}(x)$ is the sample spectra

The spectra for different thickness are represented on Fig. 5.16, for the pure polyurethane foam sample: 


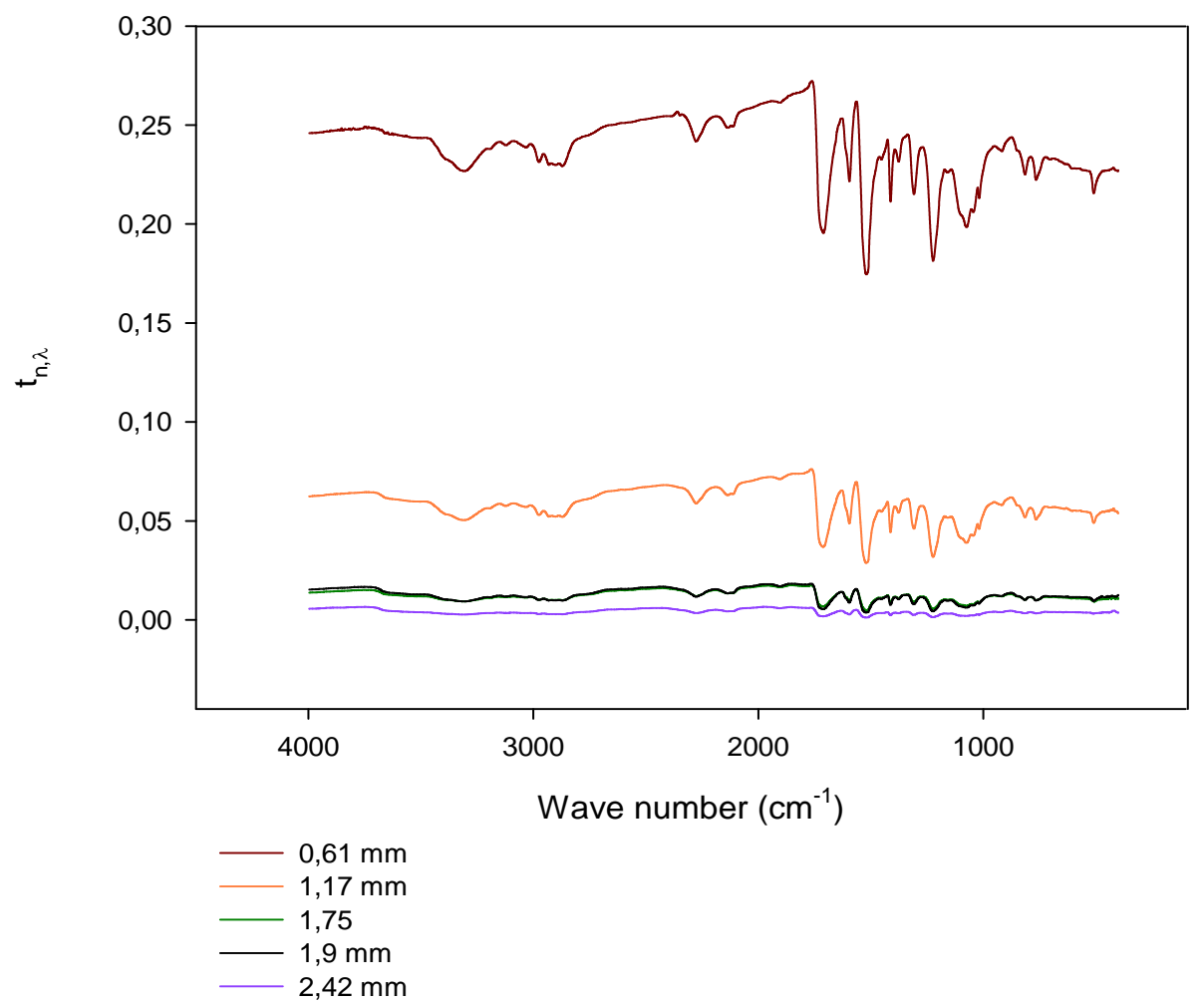

FIGURE 5.16.- Transmittance values for different sample thickness $(0.61,1.17,1.75,1.9$ and $2.42 \mathrm{~mm})$. Pure polyurethane foam.

By means of a linear fitting ( $\operatorname{Ln}\left(\tau_{e, \lambda}\right)$ vs. $\left.L\right), K_{e, \lambda}$ can be obtained (Fig. 5.17) as the slope of this curve for each $\lambda$. Fig 5.18 shows one example of this type of linear fittings.

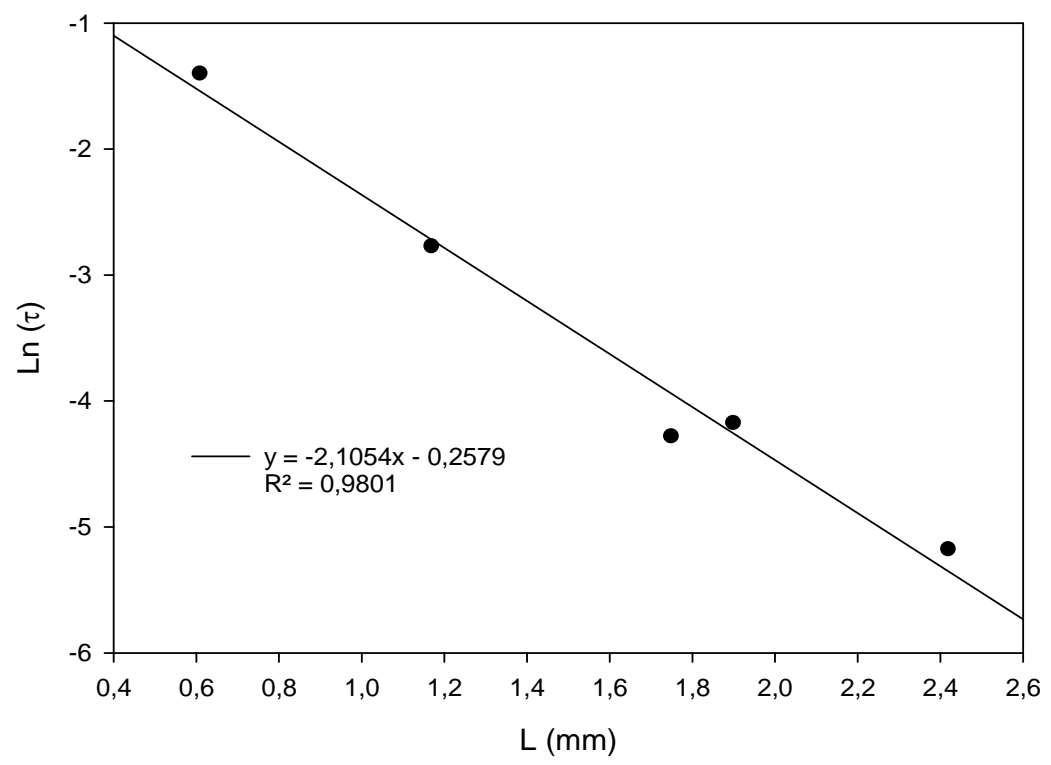

FIGURE 5.17.- Linear regression of $\operatorname{Ln}(\tau)$ vs. sample thickness, for pure material and a wave number of $3996 \mathrm{~cm}^{-1}$ 
Chapter 5: Nanoclays Concentration Effects

TABLE 5.10.- Average $\mathrm{R}^{2}$ for the different waves number and for the different samples

\begin{tabular}{cc}
\hline Sample (nanoclays \%) & $\mathbf{R}^{\mathbf{2}}$ \\
0 & 0.988 \\
0.5 & 0.996 \\
1 & 0.995 \\
3 & 0.985 \\
5 & 0.990 \\
\hline
\end{tabular}

The linear fittings were performed for all the wave numbers in the spectral region under study. Table 5.10 shows the average of the $R^{2}$ values for all the linear regressions carried out. The values are close to 0.99 probing a good correlation in the $K_{e, \lambda}$ versus $L$ fittings.

(a)

(b)

(c)

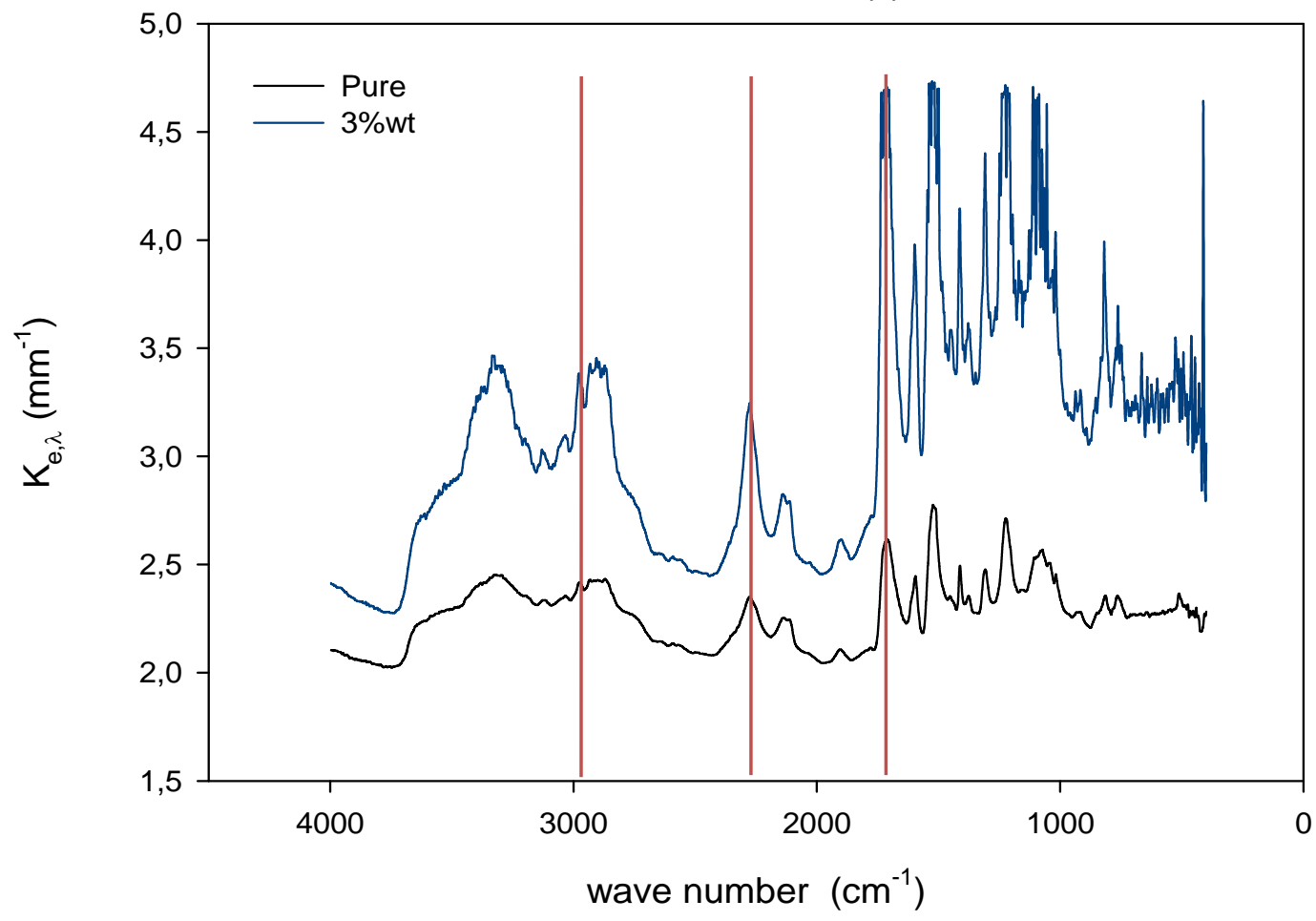

FIGURE $5.18 \mathrm{~K}_{\mathrm{e}, \lambda}$ as a function of the wavenumber, for the sample containing 0 and $3 \mathrm{wt} \%$ nanoclays, and some characteristic peaks. 
Figure 5.18 shows $K_{e, \lambda}$ as a function of the wavenumber, for the pure polyurethane sample and the one containing $3 \% \mathrm{wt}$ nanoclays. As expected, the extinction coefficient is clearly higher for the wave numbers at which the base polymer absorbs more energy. There are plenty of peaks as is usual in polyurethane foams; some of the most notable, from a compositional point of view, are for example $2270 \mathrm{~cm}^{-1}$ (isocyanate peak, (b)), $2970 \mathrm{~cm}^{-1}$ (CH stretch, reference group in polyurethane (a)), and $1725 \mathrm{~cm}^{-1}$ (free urethane group (c)) $)^{29,30}$. It is also interesting that the material containing the clay particles show higher values in all the spectral region under study.

\section{Calculation of the Rosseland Extinction Coefficient: $K_{e, R}$ or $K$}

In practical applications, radiation travels only a short distance (mean free path) before being scattered or absorbed. The transferred energy depends only on the intermediate vicinity of the position being considered. This approximation is called diffusion approximation (in this process, the heat flux is proportional to the local gradient of the potential). In this case the radiative heat flux $q_{r}(x)$ can be expressed as in Eq. $11^{26}$ where $\sigma T^{4}$ is the black body emissive power, $\sigma$ is the Stefan-Boltzmann constant, $T$ is the temperature and $\lambda_{r}$ is the radiative conductivity:

$$
q_{r}(x)=\frac{4}{3 K_{e, R}} \frac{\partial e_{b}}{\partial x}=\frac{-16 \sigma T^{3}}{3 K_{e, R}} \frac{\partial T}{\partial x}=-\lambda_{r} \frac{\partial T}{\partial x}
$$

Foams used in real applications are usually thick enough (several millimetres thick) to be considered optically thick; therefore, the radiative flux can be approximated by Rosseland equation ${ }^{31}$ as follows:

$$
\lambda_{r}=\frac{16 n^{2} \sigma T^{3}}{3 K_{e, R}}
$$

Where $n$ is the effective index and $K_{e, R}$ is the Rosseland mean extinction coefficient. For polymer foams, $n$ is close to one ${ }^{32}$. As it was mentioned in Chapter 4 , this approximation is valid in this study because the foams under analysis have a volume of gas (porosity) higher than $95 \%$.

The Rosseland approximation is valid when the medium absorbs and scatters isotropically. Under these conditions, $K_{e, R}$ can be obtained with the following equation ${ }^{23,27,28}$ : 
Chapter 5: Nanoclays Concentration Effects

$$
\frac{1}{K_{e, R}}=\frac{\int_{0}^{\infty} \frac{1}{K_{e, \lambda}} \frac{\partial e_{b, \lambda}}{\partial T} d \lambda}{\int_{0}^{\infty} \frac{\partial e_{b, \lambda}}{\partial T} d \lambda}
$$

Where $e_{b, \lambda}$ is the spectral black body emissive power and $\lambda$ is the wavelength.

TABLE 5.11 Experimental results of the Rosseland extinction coefficient

\begin{tabular}{cc}
\hline Sample (nanoclays \%) & $\mathrm{K}_{\mathrm{e}, \mathrm{R}}\left(\mathrm{cm}^{-1}\right)$ \\
0 & 23.18 \\
1 & 25.47 \\
3 & 30.42 \\
5 & 33.68 \\
\hline
\end{tabular}

Therefore, the Rosseland mean extinction coefficient is an average value of $K_{e, \lambda}$ weighed by the local spectral energy flux. Once $K_{e, \lambda}$ is measured, it is possible to obtain $K_{e, R}$ (or $K$ ) using equation 7. The Rosseland mean extinction coefficient $\left(K_{e, R}\right)$ for the samples under study are calculates using Eq. 13 and summarized in Table 5.11. A preliminary analysis of these results shows that the extinction coefficient increases when the clays are added, showing a maximum for a $3 \%$ clays concentration.

\subsubsection{Modelling of the thermal conductivity}

\subsubsection{Modelling the Extinction Coefficient}

Glicksman and coworkers ${ }^{16,19,33,37}$ proposed an equation to predict the extinction coefficient of closed-cell polyurethane foams. They considered pentagonal dodecahedral cells and an isotropic foam as a set of randomly oriented blackbody struts. They neglected scattering by the cell walls. The strut cross section was constant and occupied two-thirds of the area of an equilateral triangle formed at the vertices; the Glicksman extinction coefficient $\left(\mathrm{K}_{\mathrm{G}}\right)$ depends on the cell size $(\phi)$, foam density $\left(\rho_{f}\right)$ and solid polymer density $\left(\rho_{s}\right)$ : 


$$
K_{G}=4.10 \frac{\sqrt{f_{S} \frac{\rho_{f}}{\rho_{s}}}}{\phi}
$$

where 4.10 is a constant related to the cell geometry and $f_{S}$ is the mass fraction in the struts.

Glicksman et al. also included the absorption of the cell walls $\left(K_{H} K_{w}\right.$, where $K_{w}$ is the extinction coefficient of the solid polymer). This contribution was then combined with that of the struts to yield the overall extinction coefficient of the foam (equation 16)

$$
\begin{gathered}
K_{G}=K_{\text {edges }}+K_{H} K_{W} \\
K_{G}=4.10 \frac{\sqrt{f_{S} \frac{\rho_{f}}{\rho_{s}}}}{\phi}+\left(1-f_{S}\right) \frac{\rho_{f}}{\rho_{s}} K_{W}
\end{gathered}
$$

The cell wall term, which is valid for foams with thin cell walls $(\delta<30 \mu \mathrm{m})$, includes the hypothetical extinction coefficient for a uniform material occupying the entire volume of the foam and having the same attenuation as thin cell walls. As it has been mentioned $K_{w}$ is the extinction coefficient of the solid polymer, and the value for $\mathrm{PU}\left(60000 \mathrm{~m}^{-1}\right)$ was obtained from literature ${ }^{22}$.

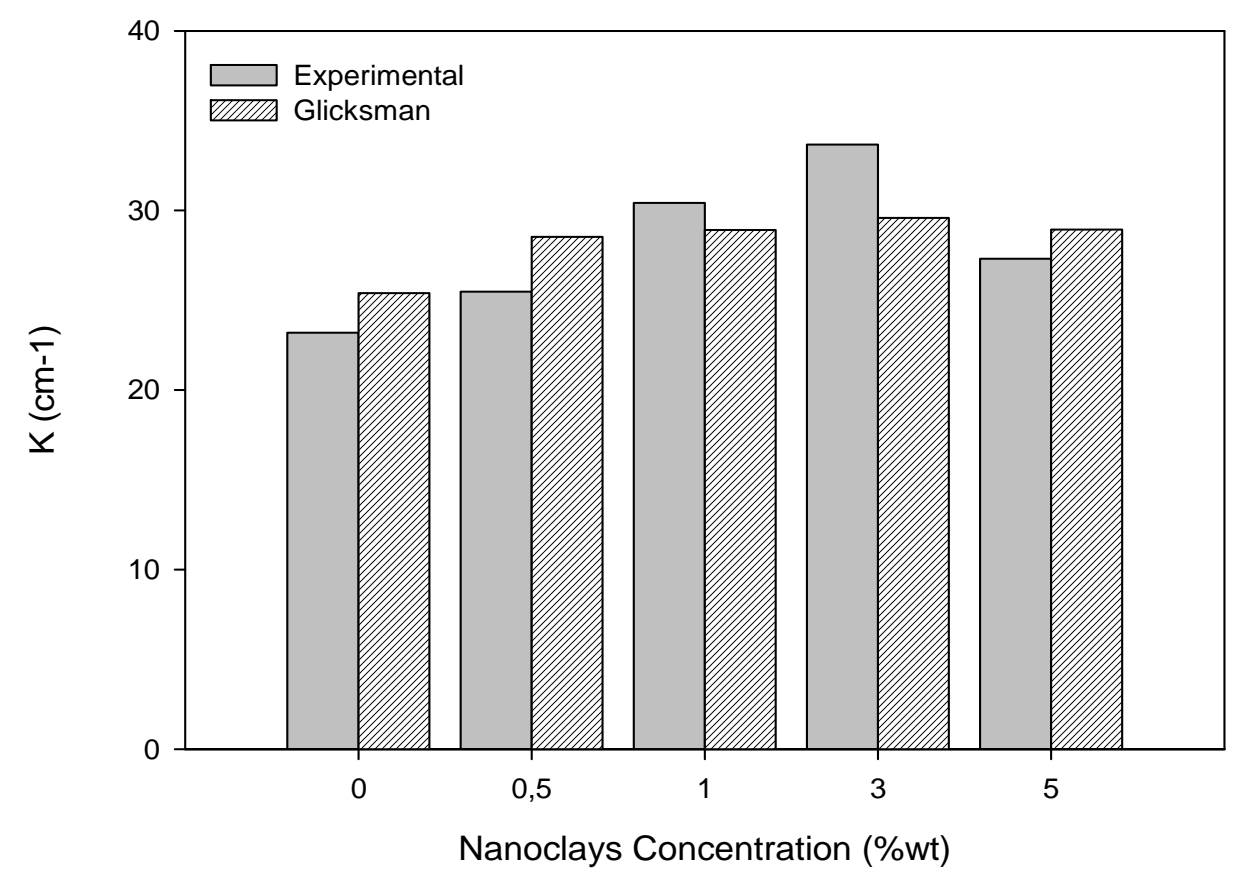

FIGURE 5.19.- Glicksman model / experimental correlation for the extinction coefficient 
The results obtained when $\mathrm{K}$ is calculated using Equation 16 and the experimental extinction coefficients (Table 6) are shown in Figure 5.19 as a function of nanoclays concentration. Similar values and a similar trend as a function of the clays content are observed for the Glicksman model and the experimental results. In both cases $\mathrm{K}$ increases when the clays are added, with an increase up to $3 \%$ nanoclays concentration, and then a slight reduction.

The average difference between the $\mathrm{K}$ theoretical and experimental values can be observed in Table 5.12, with a variation of $\pm 5-10 \%$. But this difference is not constant and there are changes with the amount of nanoclays. In general terms, there are modifications in the extinction coefficient behaviour by the addition of the nanoclays that cannot be explained only by a reduction of the cell size or a modification of the mass fraction in the struts, as both terms are included in the Glicksman model. In fact, the data of figure 5.20 show that Glicksman model predict smaller changes in $\mathrm{K}$ than the ones experimentally measured. The two components of Glicksman equation include information about the cellular structure and about the material that forms the cells; then if the Glicksman model is taken as valid, the difference with the experimental data could be associated to a change in $\mathrm{K}_{\mathrm{w}}$ due to the introduction of nanoclays.

TABLE 5.12 Extinction coefficients: experimental values calculated from the Glicksman model. Difference between them and extinction coefficient of the solid material obtained from Eq. 16 and experimental data.

\begin{tabular}{ccccc}
\hline $\begin{array}{c}\text { Sample } \\
\text { (nanoclays } \\
\text { concentration \%wt.) }\end{array}$ & $\mathrm{K}(\exp )\left(\mathrm{cm}^{-1}\right)$ & $\begin{array}{c}\text { K Glicksman } \\
\left(\mathrm{cm}^{-1}\right)\end{array}$ & Variation \% & $\begin{array}{c}\mathrm{K}_{\omega}\left(\mathrm{m}^{-1}\right) \text { exp. } \\
\text { (Calculated } \\
\text { using Eq. 16) }\end{array}$ \\
0 & 23.18 & 25.40 & 9.56 & 46266 \\
0.5 & 25.47 & 28.53 & 11.99 & 42946 \\
1 & 30.42 & 28.91 & -4.94 & 68945 \\
3 & 33.68 & 29.59 & -12.14 & 97505 \\
5 & 27.31 & 28.93 & 5.95 & 46488
\end{tabular}

The higher $\mathrm{K}_{\omega}$ are obtained for the materials containing 1 and 3 wt\% clays, the value for $3 w t \%$ clays is two times higher than the one calculated for the pure polymer. These results suggest that clays could act as IR blockers, contributing to reduce the heat flow by radiation. 


\subsubsection{Prediction of Thermal Conductivity}

It is well known that the thermal conductivity of polymer foams is due to four mechanisms: conduction along the cell walls and the struts of the solid polymer $\left(\lambda^{s}\right)$, conduction through the gas phase $\left(\lambda^{g}\right)$, thermal radiation $\left(\lambda^{r}\right)$, and convection within the cells $\left(\lambda^{c}\right)$. The total heat flow $\left(\lambda^{t}\right)$ is a result of the four contributions and can be expressed by a superposition of each mechanism taken separately ${ }^{22,34-38}$ :

$$
\lambda^{t}=\lambda^{s}+\lambda^{g}+\lambda^{r}+\lambda^{c}
$$

The convective heat transfer is assumed to be negligible ${ }^{22,39}$ because of the very small cell size (350-500 $\mu \mathrm{m}$ ) of the foams under study. In a first approximation, it is possible to consider conductive terms of the gas (Eq. 18) and the solid (Eq. 19), and subtract them from the experimental value of the conductivity to obtain an experimental value of the thermal radiation term ${ }^{39}$. The expression of these conductive terms is shown in equations 12 and 13 , where $\mathrm{V}_{\mathrm{g}}$ is the volume fraction of the gas phase $\left(1-\rho_{f} / \rho_{s}\right), \lambda_{\mathrm{g}}$ is the thermal conductivity of the gas at a given temperature, $\mathrm{V}_{\mathrm{s}}$ is the volume fraction of solid $\left(\rho_{f} / \rho_{s}\right), \lambda_{\mathrm{s}}$ is the thermal conductivity of solid polyurethane $\left(0.26 \mathrm{~W} \cdot \mathrm{m}^{-1} \mathrm{k}^{-1}\right)^{36}$ and $\mathrm{f}_{\mathrm{s}}$ is the mass fraction in struts. The contribution to the thermal conductivity from the gas phase (eq 18) depends on the own nature of the gas. In our case, the gas is air at atmospheric pressure for which the conductivity at $20 \stackrel{\circ}{ } \mathrm{C}$ has been taken as $25.3 \mathrm{~mW} \cdot \mathrm{m}^{-1} \mathrm{k}^{-1}$. The contribution of the solid PU to the thermal conductivity has been considered constant with the temperature.

$$
\begin{gathered}
\lambda^{g}=\lambda_{g} V_{g} \\
\lambda^{s}=\left(\frac{2}{3}-\frac{f_{s}}{3}\right) \lambda_{s} V_{s}
\end{gathered}
$$

The last expression can be modified to introduce the effect of cellular anisotropy, as it is shown below:

$$
\lambda^{s}=\frac{\lambda_{s} V_{s}}{3}\left[f_{s} \sqrt{\frac{a}{b}}+2\left(1-f_{s}\right)\left(\frac{a}{b}\right)^{1 / 4}\right]
$$

where $a$ is the cell size in the direction of the temperature gradient, and $b$ is the cell size in the perpendicular direction to the heat flow. 
a.-

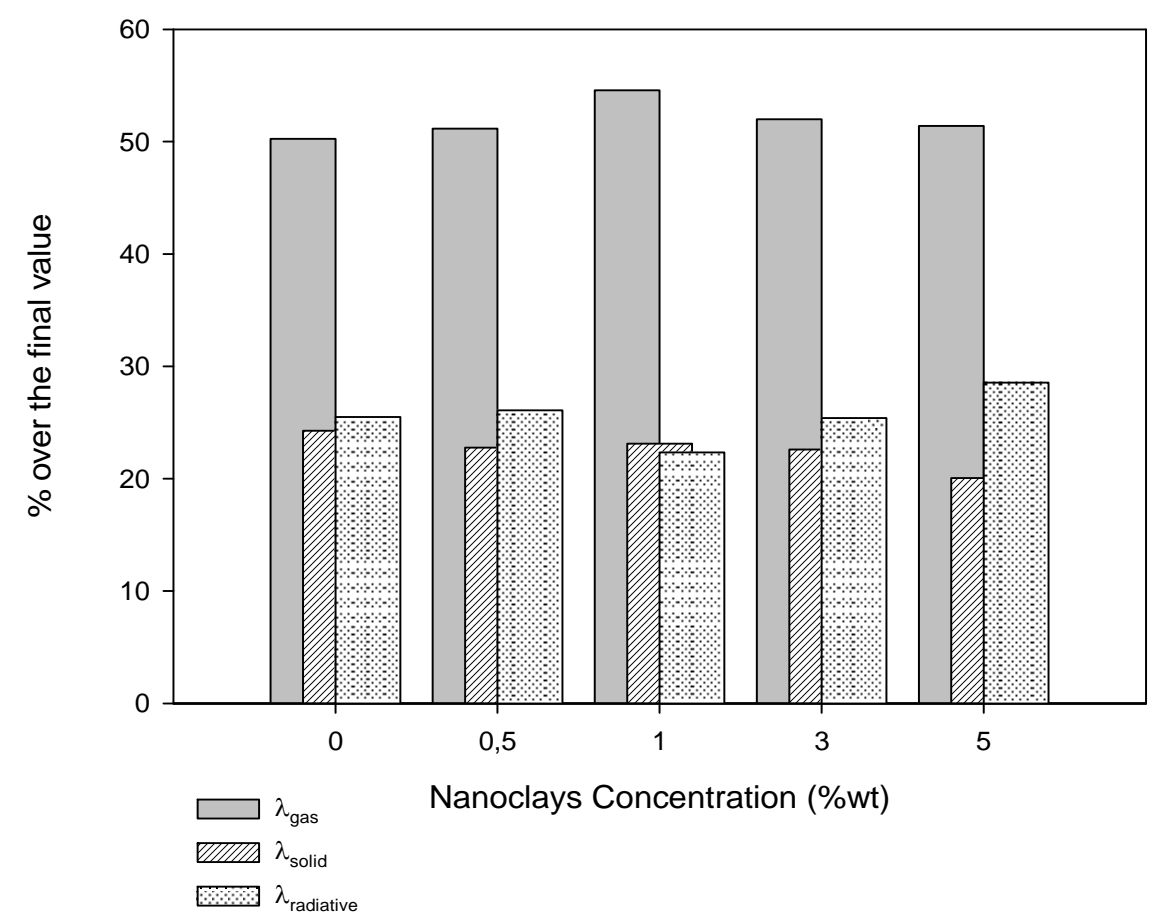

b.-

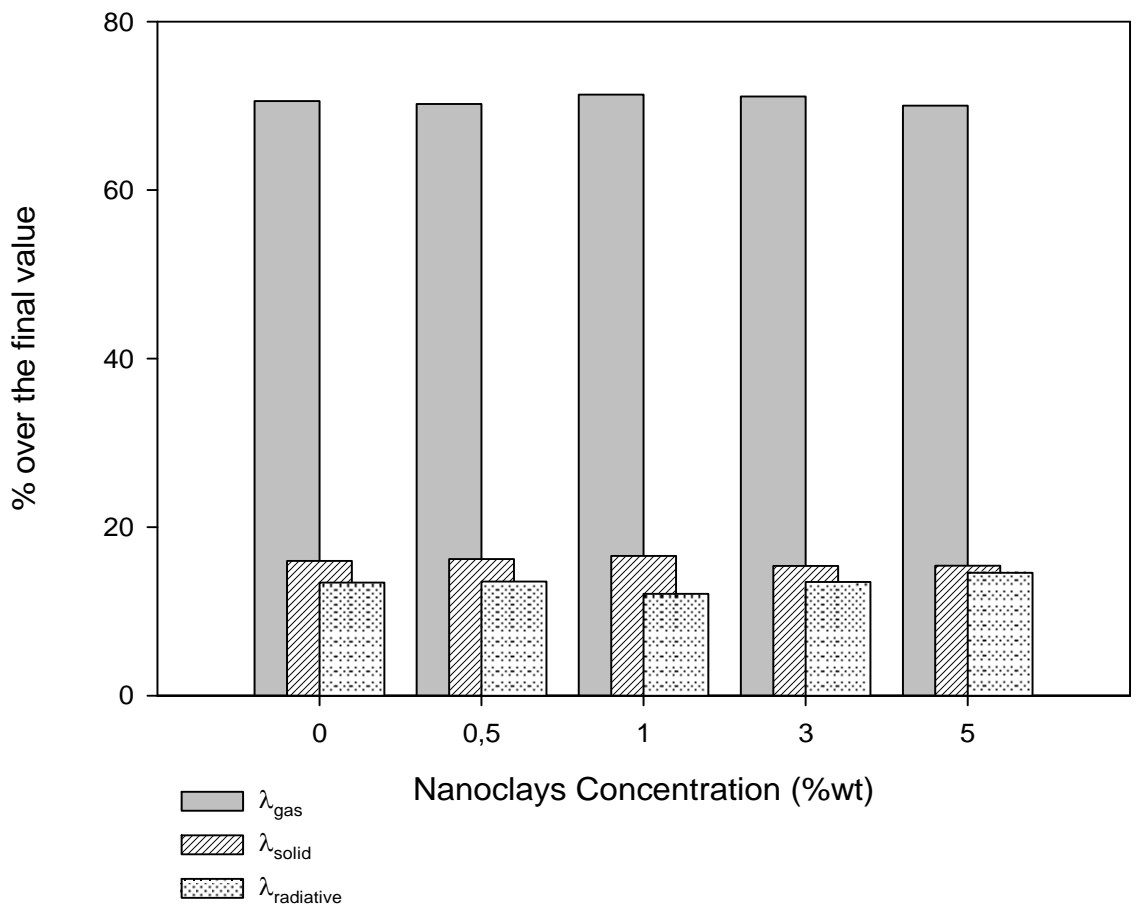

FIGURE 5.20 Weight of the different contributions in the thermal conductivity, for different nanoclays concentration: a.- two days after manufacturing; b.- 40 days after manufacturing 
Using Equations 18 and 19 and the characteristics of the cellular structure in each foam it is possible to calculate the weight of each term on the thermal conductivity of the measured foams: Figure 5.20.a,b show the results of these calculations for the gas phase conductive term and the solid phase conductive term, assuming the radiative term as the difference between the experimental conductivity and the above two, as it can be obtained from Eq. 17. With these calculations, it is possible to observe that the conductivity of the gas phase is responsible of around $50 \%$ of the final conductivity of the foam a short time after manufacturing, while Fig. 5.20.b shows that 40 days after manufacturing is responsible of around $70 \%$. This information confirms the data from Fig. 5.15.b, where it is observed a higher reduction of the thermal conductivity for short times: this reduction is confirmed by the lower weight of the gas phase term at short times, and corroborates the time evolution of the total conductivity (Fig. 5.13), as the air $\left(25.3 \mathrm{~mW} \cdot \mathrm{m}^{-1} \cdot \mathrm{k}^{-1}\right.$ at $\left.20 \circ \mathrm{C}\right)$ presents a higher thermal conductivity than the $\mathrm{CO}_{2}(1.45$ $\mathrm{mW} \cdot \mathrm{m}^{-1} \cdot \mathrm{k}^{-1}$ at $\left.2 \mathrm{O}^{\circ} \mathrm{C}\right)$, and the $\mathrm{CO}_{2}$ originally present inside the cells as result of the foaming reaction diffuses out the foam and is substituted by atmospheric air.

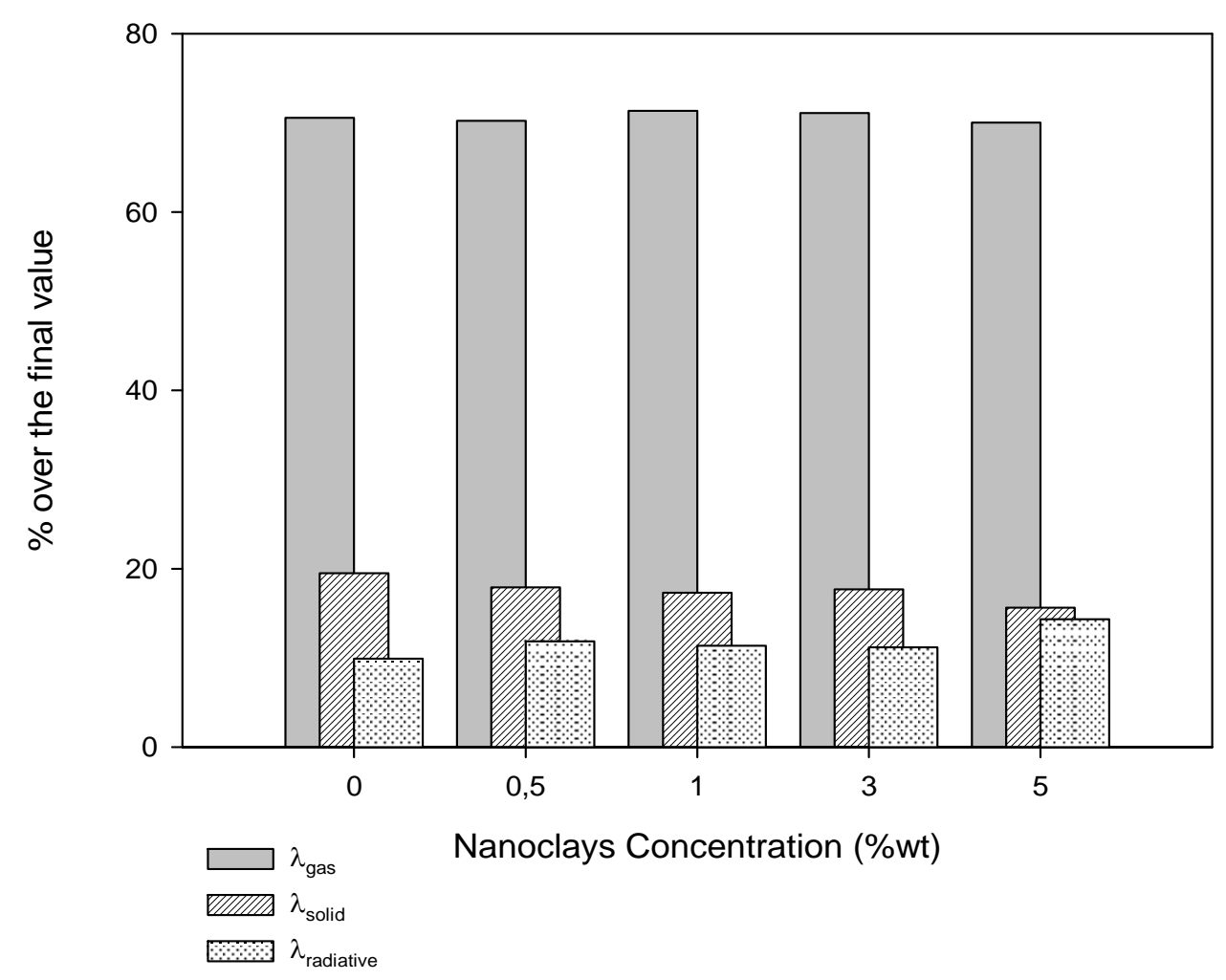

FIGURE 5.21. Weight of the different contributions in the thermal conductivity, for different nanoclays concentration, including the cellular anisotropy correction (Eq. 20). 
Assuming the anisotropy corrections (Eq. 20), some changes are observed in Fig. 5.21 with respect to Fig. 5.20.b, mainly in the solid and radiative terms. A decrease of the radiative term is clearly observed, while an increase of the solid phase weight is observed. As expected, the growing direction increases the solid contribution.

Trying to have a better understanding of the radiative term, Equation 21, the Rosseland equation, has been used to calculate the radiative term, where $K_{e, R}$ is the extinction coefficient, $\sigma$ is the Stephan-Boltzmann constant and $T$ is the temperature. The value of $K_{e, R}$ can be the experimental one or a theoretical value calculated with the Glicksman expression (Table 5.13).

$$
\lambda^{r}=\frac{16 \sigma T^{3}}{3 K_{e, R}}
$$

If we assume the validity of the Rosseland equation, the total conductivity $\left(\lambda_{t}\right)$ can be estimated by using the equation 22 :

$$
\lambda^{t}=\lambda_{g} V_{g}+\left(\frac{2}{3}-\frac{f_{s}}{3}\right) \lambda_{s} V_{s}+\frac{16 \sigma T^{3}}{3 K_{e, R}}
$$

This expression can be modified in the case of high anisotropy (Eq. 20), as it is shown below:

$$
\lambda^{t}=\lambda_{g} V_{g}+\frac{\lambda_{s} V_{s}}{3}\left[f_{s} \sqrt{\frac{a}{b}}+2\left(1-f_{s}\right)\left(\frac{a}{b}\right)^{1 / 4}\right]+\frac{16 \sigma T^{3}}{3 K_{e, R}}
$$

Once the total thermal conductivity is measured, it is possible to predict the radiative term using Eq. 22 and Eq. 23:

$$
\lambda^{\text {rad.exp. }}=\lambda^{t}-\lambda^{s}+\lambda^{g}
$$

This equation has been used in Figure 5.22.a, where the experimental value of the radiative contribution is compared with the values obtained using the Roseland equation with the two possible data for the extinction coefficient. It is possible to observe similar trends for the experimental values and these obtained using the Rosseland equation (Figure 5.22.b) for low nanoclays concentration, but also a different trend for the higher values of nanoclays concentrations. 
a)

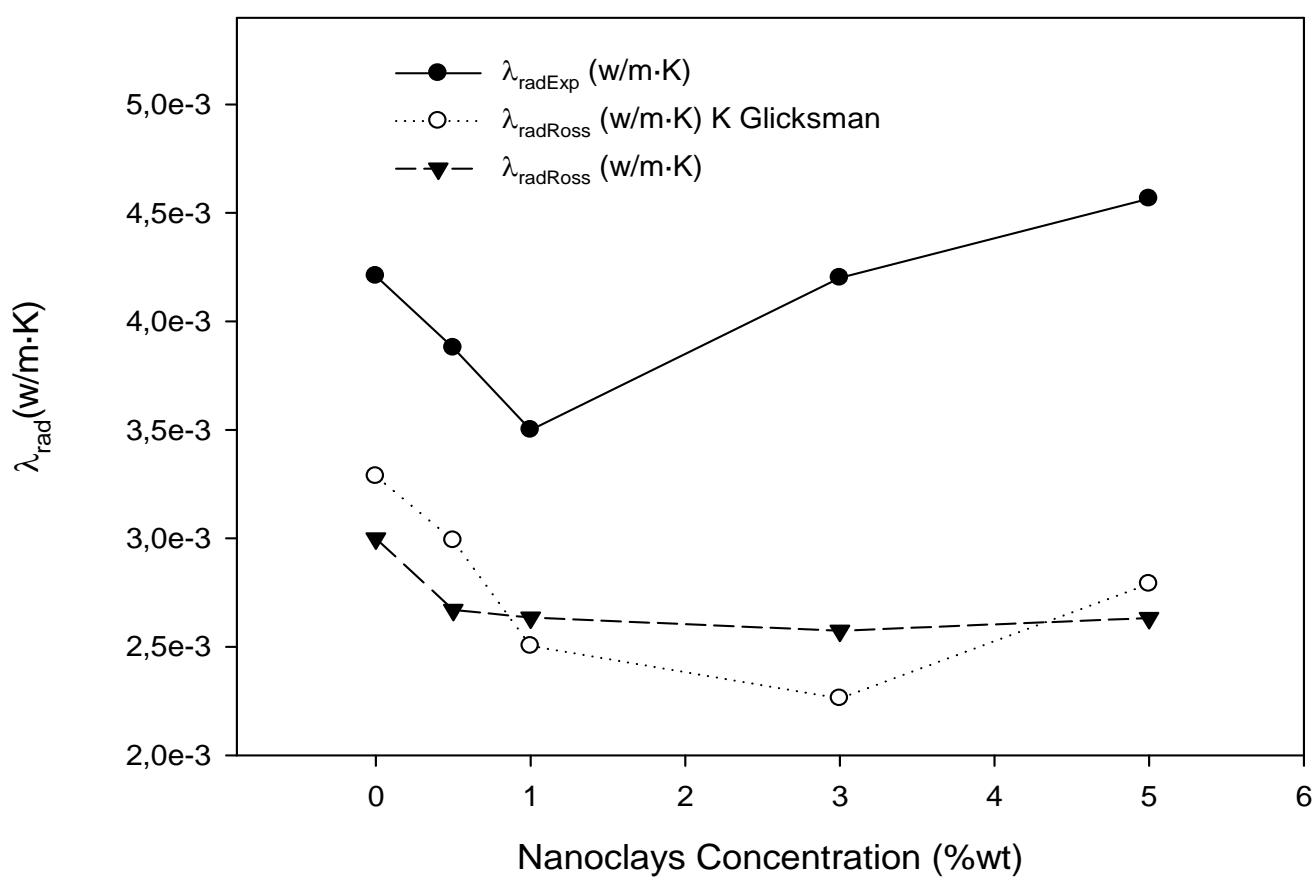

b)

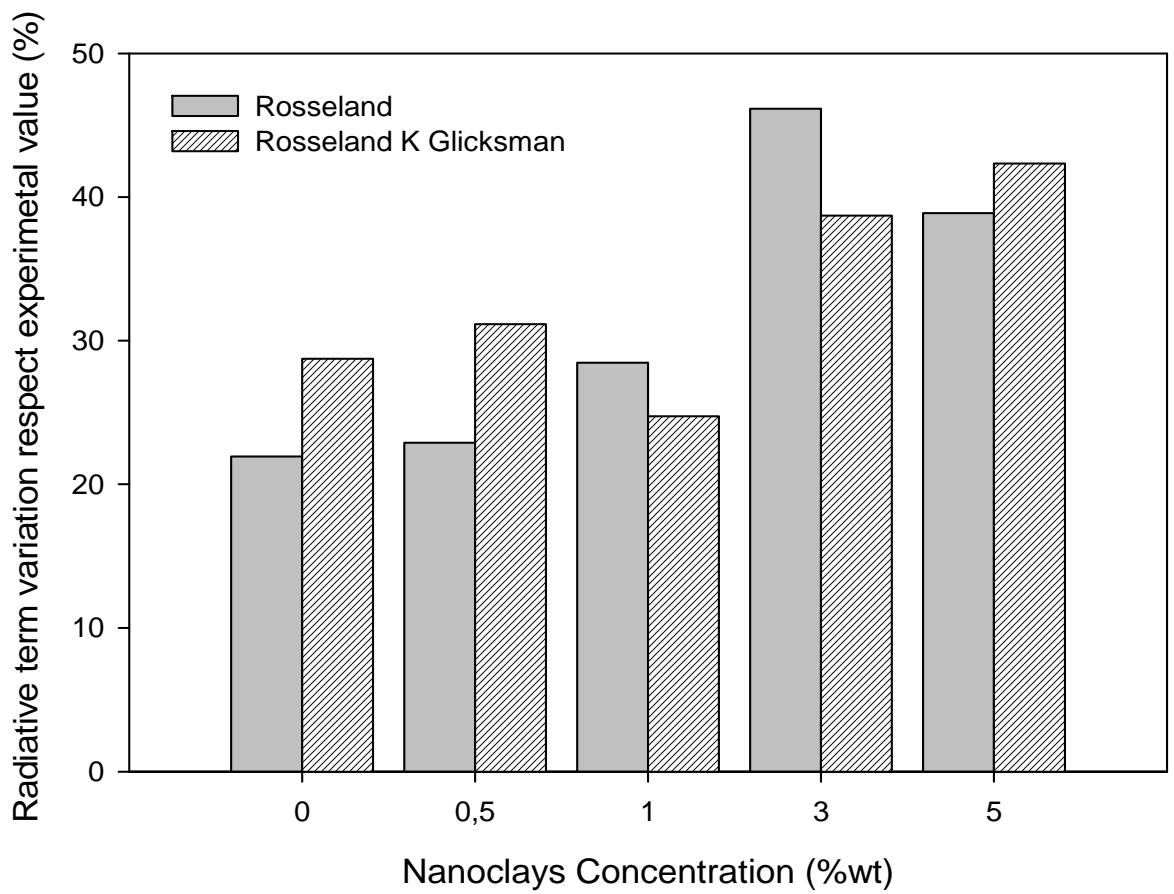

FIGURE 5.22 Radiative terms comparative: (a) absolute values, (b) differences in percentage between theoretical and experimental values of the radiative contribution

Whereas for experimental values the minimum is observed for $1 \%$ wt nanoclays concentration, for theoretical values this minimum is obtained for $3 \%$ wt nanoclays 
concentrations. It can be also observed how for 3 and 5\% wt nanoclays concentration the differences in the predictions are higher.

a)

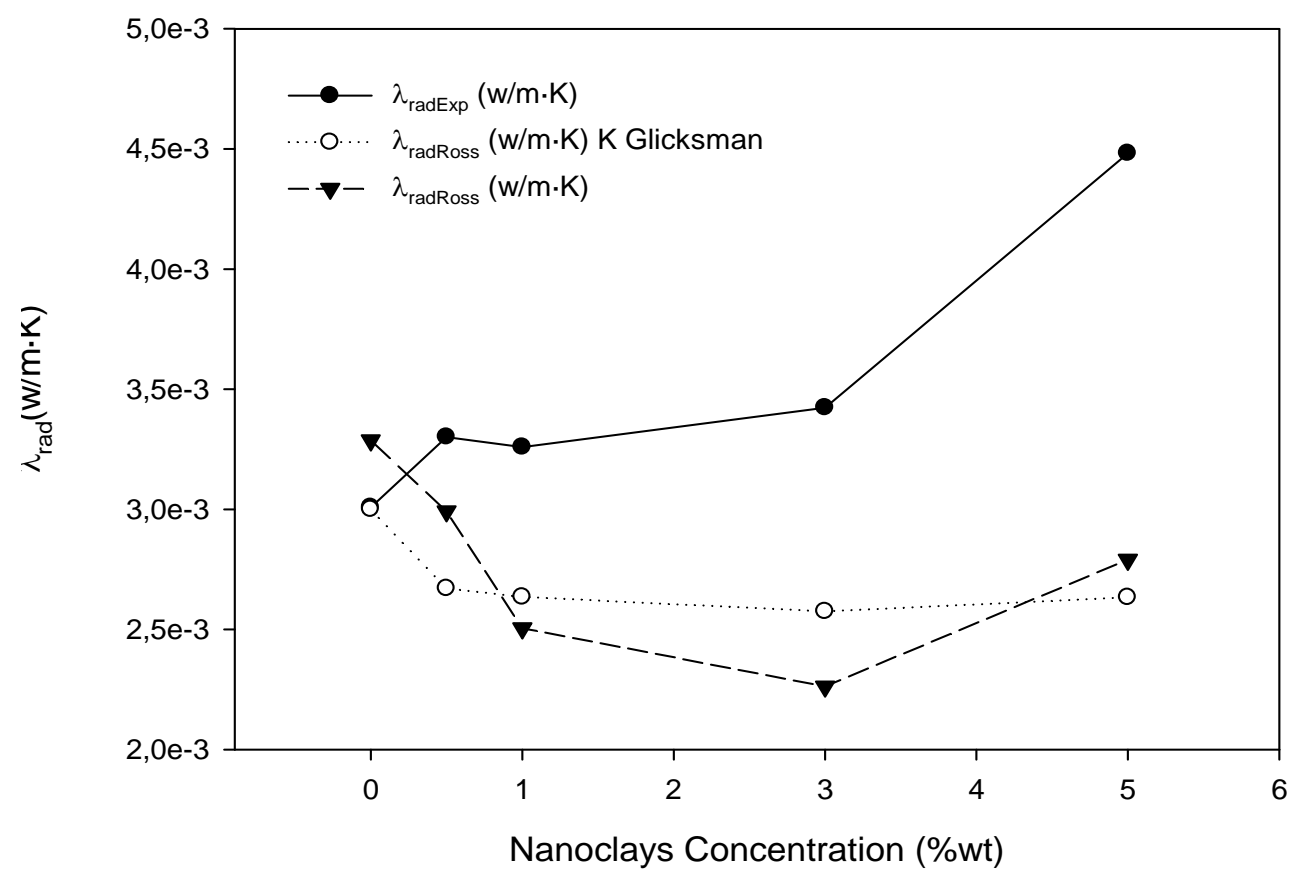

b)

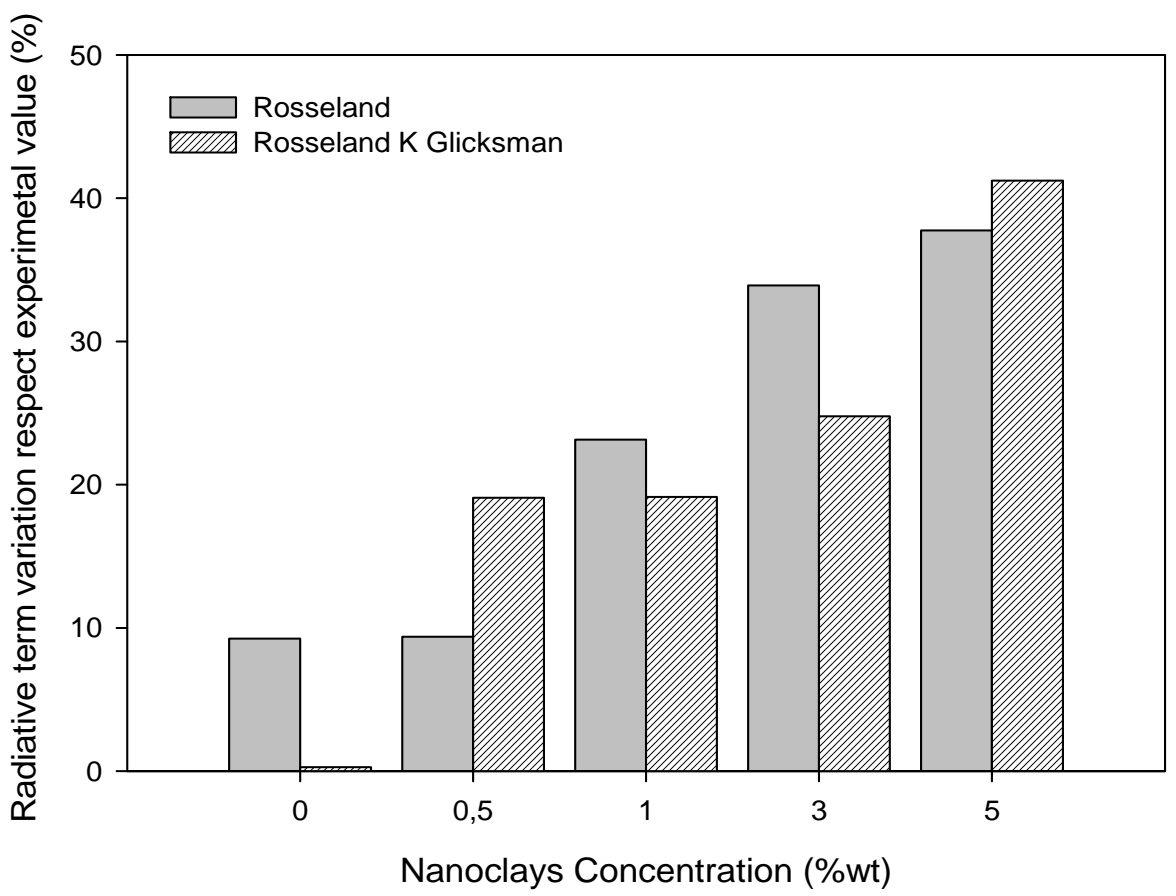

FIGURE 5.23 Radiative terms comparative with cellular anisotropy corrections: (a) absolute values, (b) relative to experimental values variations 
If the anisotropy of the cellular structure is introduced in these calculations, the results are modified (Fig 5.23). The inclusion of the cellular anisotropy corrections results in a better correspondence between experimental data and the two estimations, at least for low nanoclays concentrations, although it also implies different trends for the different data.

a)

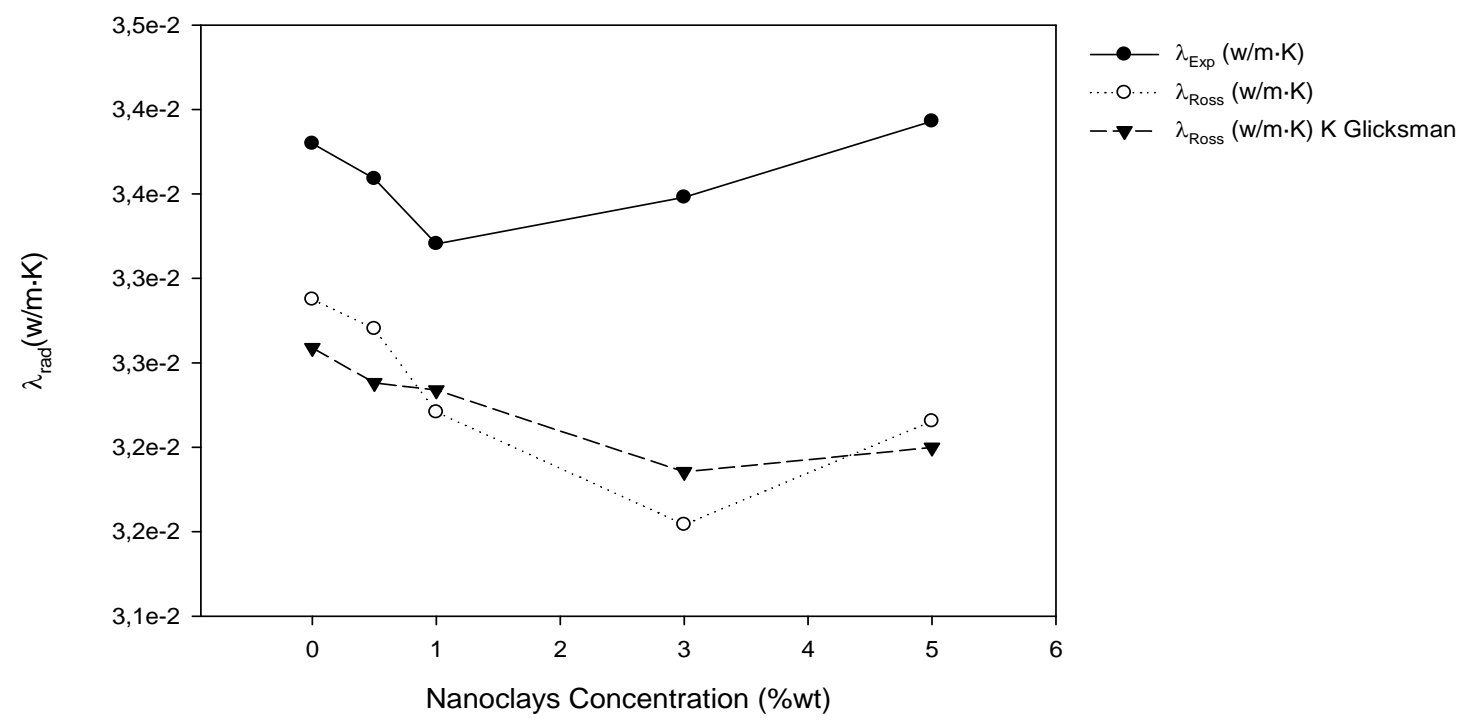

b)

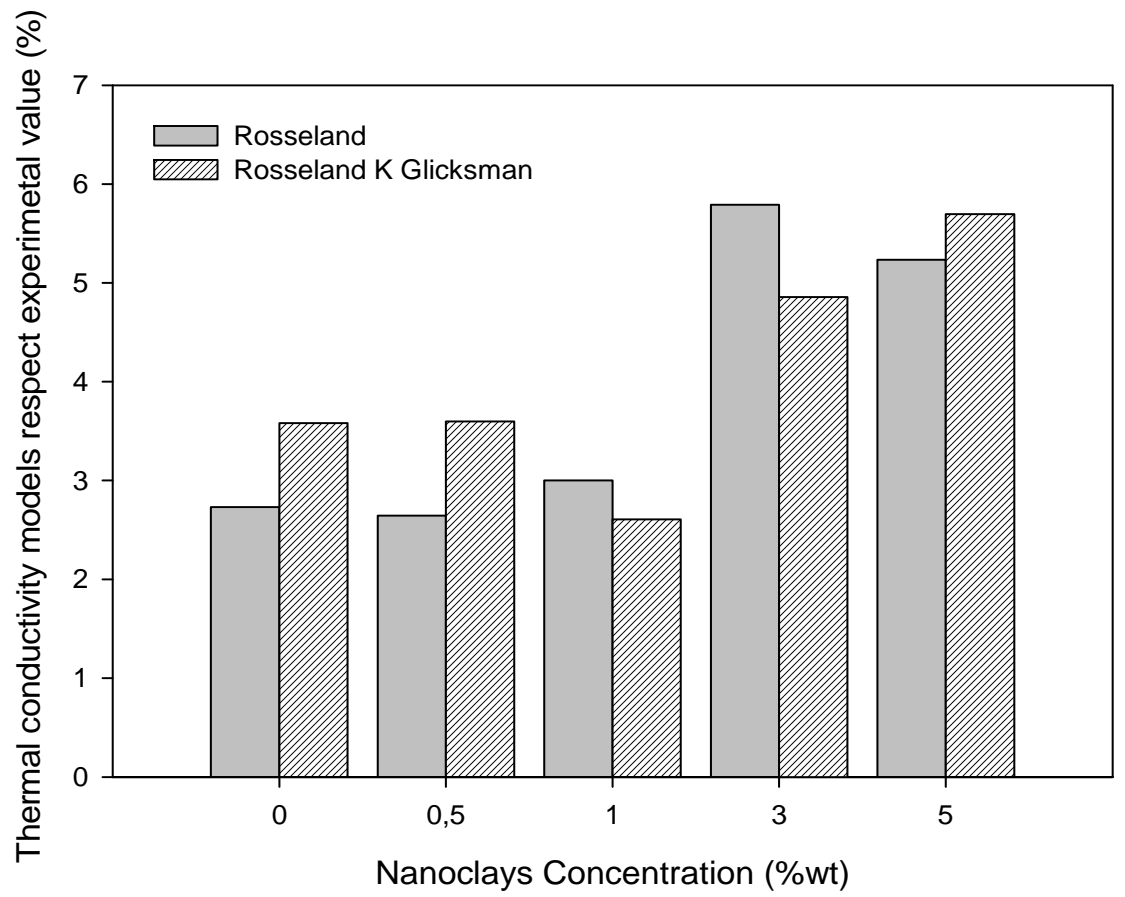

FIGURE 5.24. Total conductivity comparative: (a) absolute values, (b) relative to experimental values variations.

Figure 5.24.a and $b$ shows the experimental data for the total conductivity in comparison with the theoretical ones using the two values obtained for the extinction 
coefficient. The predictions are close to the real values (difference lower than $7 \%$ ), being the theoretical values lower than the real ones. The two theoretical results are very close each other. Another observation is that while the experimental data presents a minimum at $1 \mathrm{wt} \%$ clays, the theoretical ones have the minimum at 3wt\% nanoclays concentration.

a)

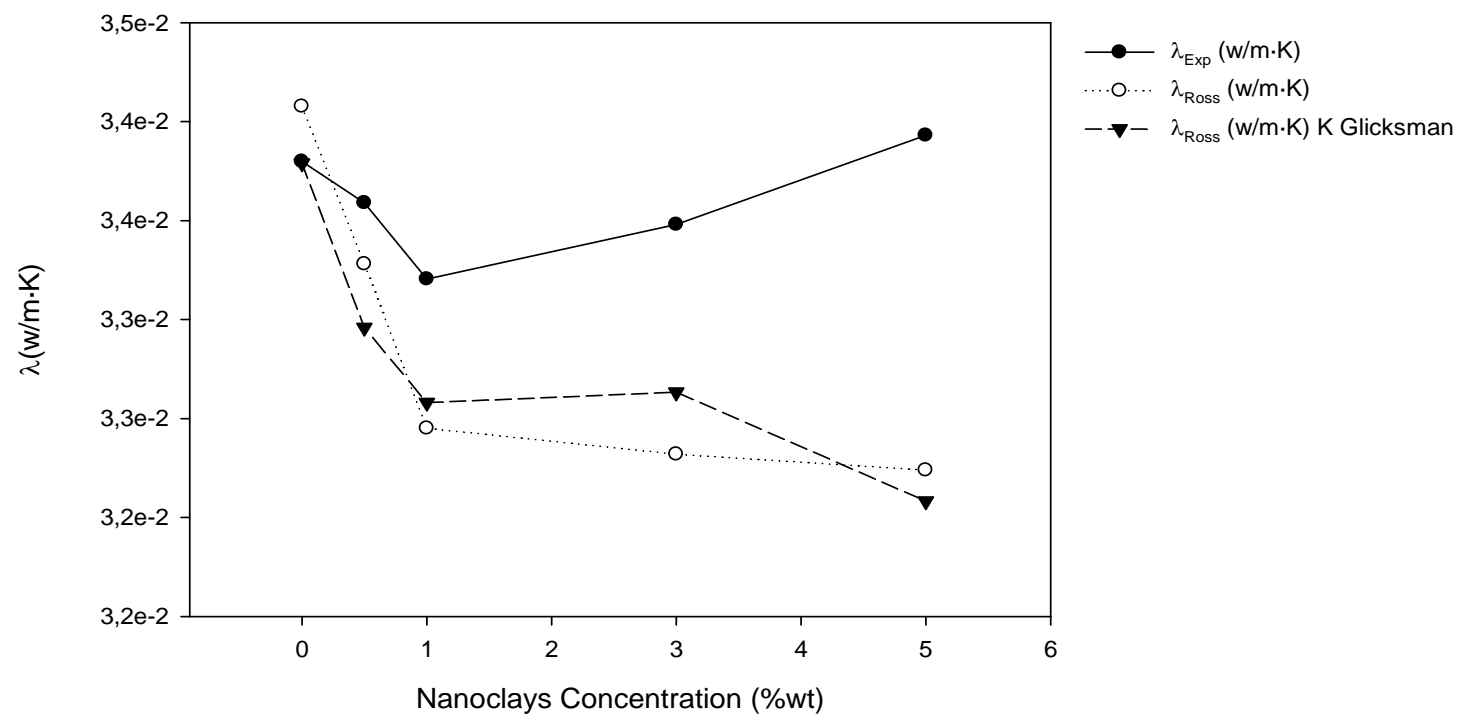

b)

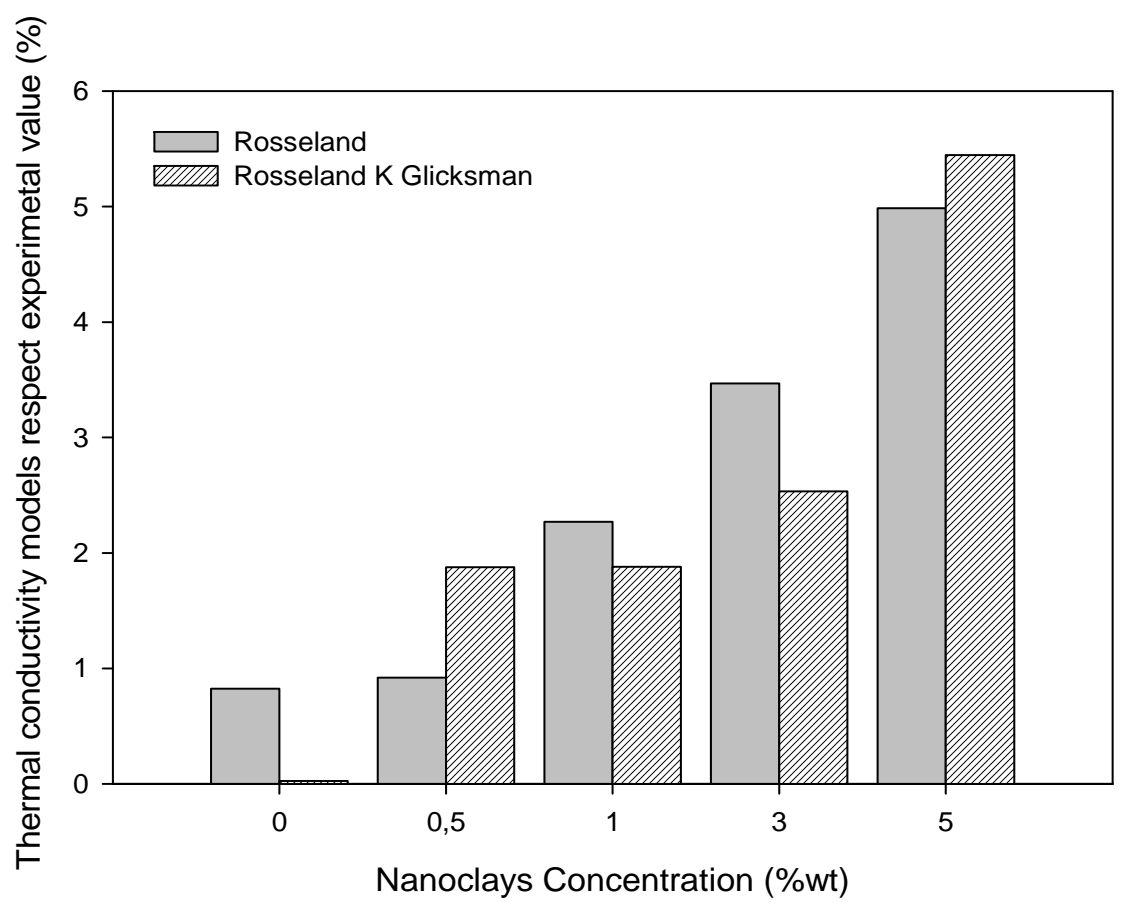

Figure 5.25 Total thermal conductivity comparative including cellular anisotropy correction: (a) absolute values, (b) \% difference in comparison with experimental values. 
Once more, introducing anisotropy corrections, a better correlation is observed, showed in Fig. 5.25. In addition, a more similar trend between the experimental and the estimated values is observed.

\subsection{Discussion}

Two different topics will be discussed in the present section: mechanical properties and thermal conductivity. The nanoclays effect of adding nanoclays over these properties are considered.

First of all, we will focus on the mechanical behaviour. Despite the good dispersion and the possible intercalation achieved, mechanical properties were not significantly improved. As matter of fact, best results were achieved for a $3 \mathrm{wt} \%$ nanoclays concentration for the relative compression elastic modulus, with a reduction for higher concentrations. Our explanation is similar to the one given in Chapter 4: limited improvement or even the reduction of several mechanical properties could have its origin in the chemical interaction between urethane groups and the functionalization of nanoclays ${ }^{40,41}$. $\mathrm{H}$-bonds between urethane groups are largely responsible of mechanical properties of pure polyurethane. The nanoclays functionalization could interact with these bonds, reducing the final number of them. So the expected increase in mechanical properties due to nanoclays is limited or cancelled (see Fig. 4.21 in Chapter 4).

In the previous chapter, it was observed that a better dispersion could imply the destruction of more $\mathrm{H}$-bonds, and a larger reduction of the mechanical properties, due to a higher interaction between nanoclays and $\mathrm{H}$-bonds. In the present case, a higher concentration of nanoclays could imply a similar result than a good dispersion: a higher interaction between nanoclays and $\mathrm{H}$-bonds. Due to this, good results are obtained for lower nanoclays concentration, for which reinforcement of the polyurethane matrix by the nanoclays compensates the negative effect on the mechanical properties of nanoclays interaction with $\mathrm{H}$ bonds. However, this effect of reinforcement does not appear for higher concentrations, where a decrease in the mechanical properties is observed.

On the other hand, cellular structure changes produced by the nanoclays addition could be also related with the final mechanical properties. As it has been explained in the state of the art Chapter, closed cell structures and with a high cell size homogeneity (narrow cell size distributions) are related with better mechanical properties such as elasticity modulus or collapse strength ${ }^{15,42,43}$. Again, there is a double effect of nanoclays depending on their 
concentration: they have a reinforcement effect for lower concentrations, but for higher concentrations (5\% wt.) wider cell size distribution are produced (Figure 5.2) and a much higher value of NSD is obtained (Table 5.2). These results could also contribute in the observed reduction of the mechanical performance at higher filler loadings.

Therefore, it is possible to conclude that mechanical behavior of polyurethane foams with different amounts of nanoclays could be affected by the simultaneous effect of both explanations: an interaction between $\mathrm{H}$-bonds and nanoclays which reduces mechanical properties for high concentrations or good dispersion of nanoclays, and the presence of a bimodal, wider cell sizes reduce final properties. These effects seem to compensate or even are stronger than the potential reinforcement offered by the nanoparticles.

In order to have a complete understanding of thermal conductivity behaviour, it is necessary the analysis of the different heat conduction mechanisms. As it has been mentioned, for the range of cell sizes under study there are three different contributions to the thermal conductivity: conduction through the gas, thermal radiation and conduction along the cell walls and struts of the solid polymer. The discussion is focused in each mechanism.

- Conduction through the gas phase: This term, as can be seen in Figure 5.20 and 5.21, is the most significant in the final value of the thermal conductivity, with a weight between 71$72 \%$. For this reason, small changes in the thermal conductivity of the gas phase of the foam can produce significant changes in the conductivity. This has been shown on Figure 5.13 , where time evolution of the thermal conductivity can be observed. Gas present inside the cells changes from $\mathrm{CO}_{2}\left(14.5 \mathrm{~mW} \cdot \mathrm{m}^{-1} \cdot \mathrm{K}^{-1}\right)$ to atmospheric air $\left(25.3 \mathrm{~mW} \cdot \mathrm{m}^{-1} \cdot \mathrm{K}^{-1}\right)$ due to the diffusion through the polymeric matrix. Some calculations can be made with the reference model (equations 22 and 23); assuming that conduction through the solid and radiation conductivity are time independent. The contribution to thermal conductivity of the gas phase in the first measurement ( $t=2$ days) can be calculated subtracting from the experimental value of $\lambda$ the solid phase and the radiation term contributions. Considering Eq. 18, these calculations show that for the initial value of the thermal conductivity ( $\mathrm{t}=2$ days) the value of the gas phase conductivity $\left(\lambda_{\mathrm{g}} \cdot \mathrm{V}_{\mathrm{g}}\right)$ is between 18 and $20 \mathrm{~mW} \cdot \mathrm{m}^{-1} \cdot \mathrm{K}^{-1}$ (Figure 5.26) while 40 days after is close to 27. These data are in accordance with Fig. 5.21. $a$ and $b$, where it can be observed that the lower conductivity of the gas phase results in a lower weight of this term on the final conductivity. 
Initial values of the thermal conductivity of the gas inside the cells can be calculated as a mixture of $\mathrm{CO} 2$ and air using as a first approximation the Wassiljeva equation ${ }^{44}$ :

$$
\lambda_{m}=\sum_{i=1}^{n} \frac{y_{i} \lambda_{i}}{\sum_{j=1}^{n} y_{j} A_{i j}}
$$

Where $\lambda_{m}$ is the thermal conductivity of the mixture, $\lambda_{i}$ is the thermal conductivity of pure component $i, y_{i}$ and $y_{j}$ are the mole fractions of components $i$ and $j$ and $A_{i j}$ is a function of the binary system that is typically equal to 1 . With this equation is possible to observe that for the initial thermal conductivity measurement, approximately a $40 \%$ of $\mathrm{CO}_{2}$ present on the cells has been substituted by air (Figure 5.27). Although first measurements were made around $48 \mathrm{~h}$ after foams manufacture, influence of high temperatures of foams during and just after polymerization over the diffusion laws must be taken into account to explain these results. Moreover, insulating properties of polyurethane increase the time that the foam is at high temperature, increasing the diffusion rate of the $\mathrm{CO}_{2}$ outside the final material.

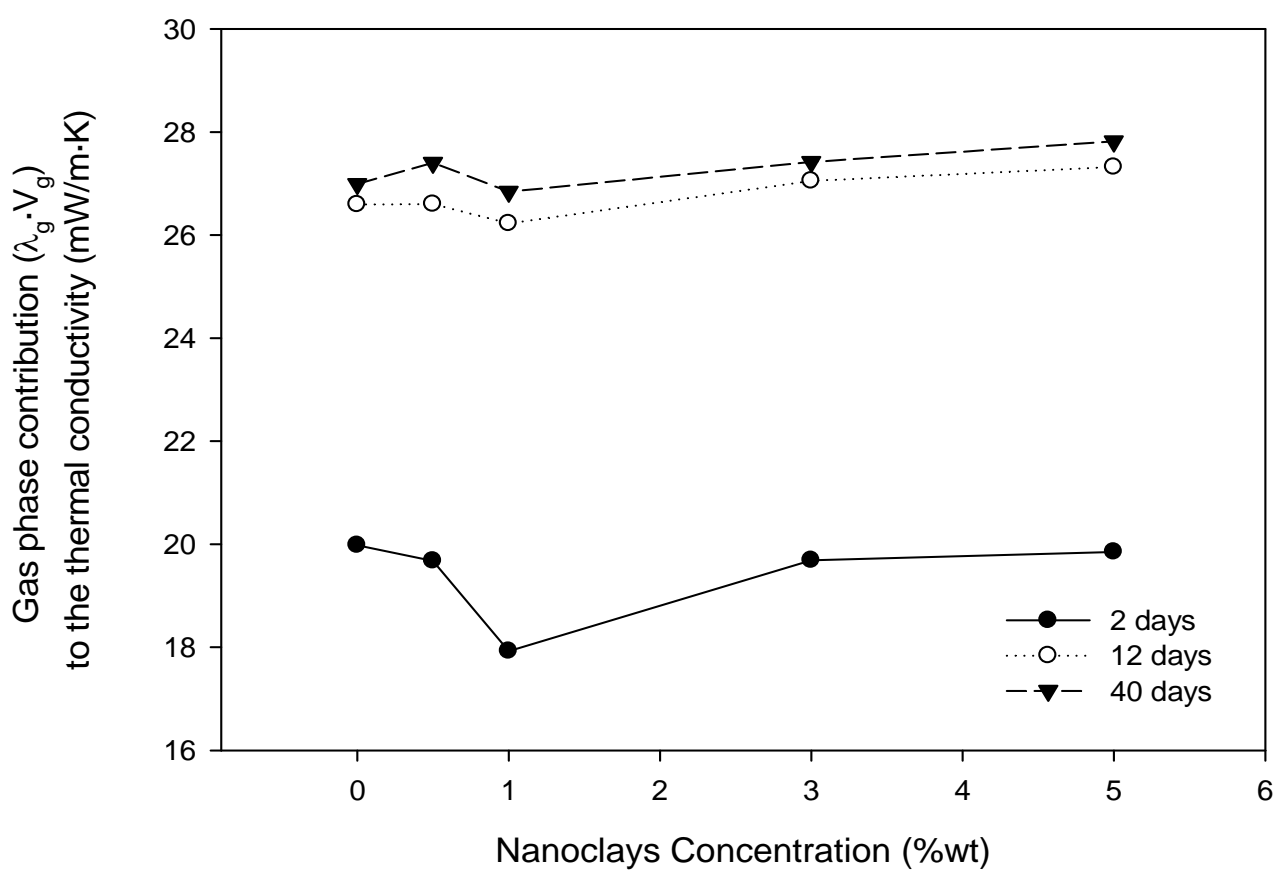

FIGURE 5.26. Thermal conductivity of the gas phase $\left(\lambda_{\mathrm{g}} \cdot \mathrm{V}_{\mathrm{g}}\right)$ in the initial measurements of the thermal conductivity $(2,12$ and 40 days after production) 


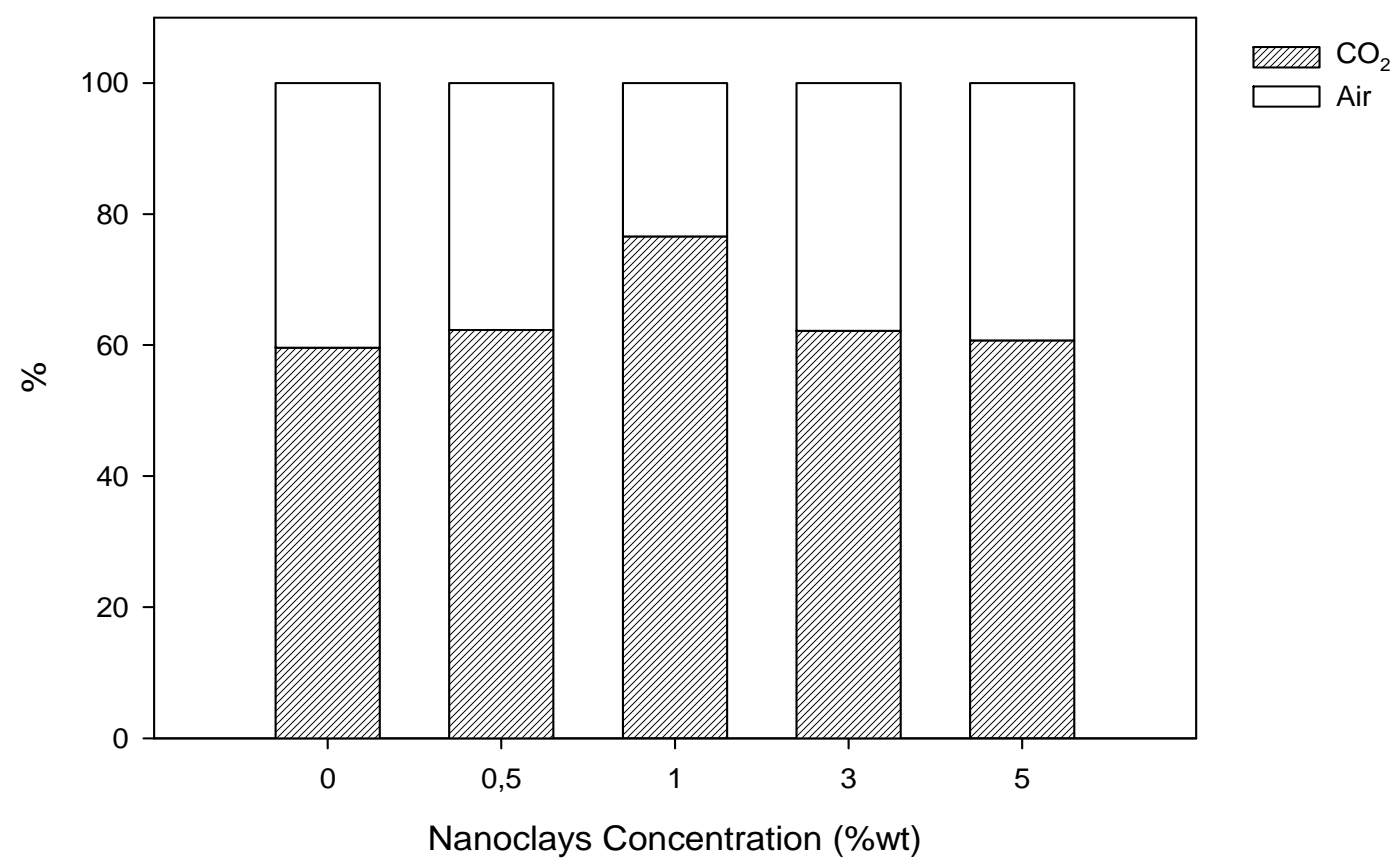

FIGURE 5.27. Concentration of gases present in the cellular structure two days after foams production

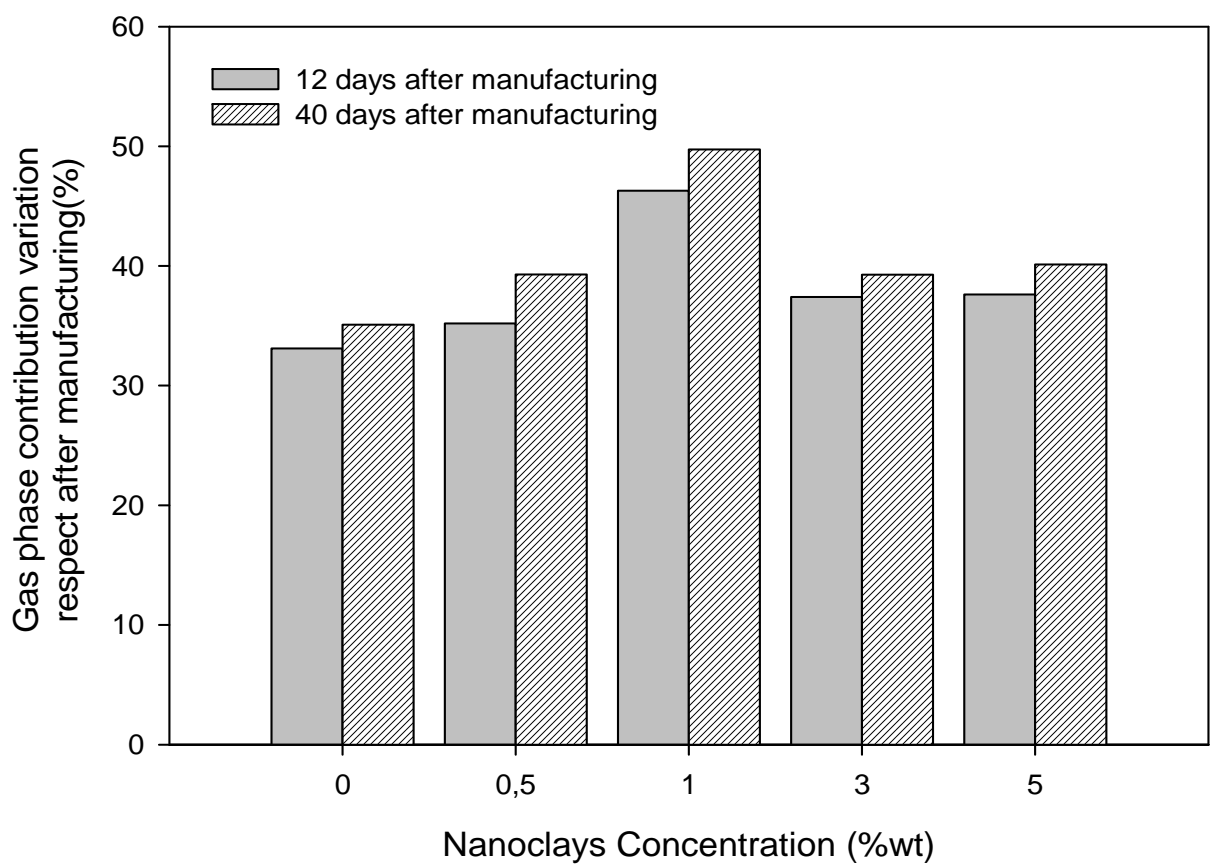

FIGURE 5.28.- Change in the gas conductivity (\%) respect to initial value

Analogue calculations can be made for measurements performed 12 days and 40 days after foam production, obtaining $100 \%$ air concentration which confirms the asymptotical 
behaviour of the time evolution. Moreover, Figure 5.28 shows the change in the thermal conductivity of the gas phase with respect to its initial value measured 2 days after manufacturing. It is possible to observe that the higher change in this term was produced between 2 days and 12 days after manufacturing, while between 12 and 40 days small changes are produced.

The differences observed as a function of clays concentration could be due to inaccuracies in the determination of the gases contribution and/or different diffusion rates due to nanoclays presence. In order to perform a more detailed analysis of this topic, experiments at different times (between 2 and 12 days) should be performed. Other factor that can affect the conduction through the gas phase, and that was studied in the previous Chapter, is the open cell content. However, this effect seems to be negligible, because the inclusion of nanoclays only increase the open cell content in a $2 \%$, except for the $0.5 \%$ nanoclays concentration, where similar values than for the pure material are obtained.

- Radiation contribution: This term experiments substantial changes by nanoclays presence. Considering Eq. 21, changes in radiation conduction are deeply related with changes in the extinction coefficient (higher extinction coefficient implies lower conductivity). In turn, accepting Glicksman model, extinction coefficient is also related with the solid polymer absorption coefficient $\left(\mathrm{K}_{\omega}\right)$, the cell size and the mass fraction in struts.

Comparing experimental values for extinction coefficient and theoretical values (taking into account only the measured changes produced by nanoclays: cell size reduction and variation in mass fraction on struts), both present a maximum for $3 \%$ nanoclays, but completely different values (table 5.13). This difference between experimental data and modelling data makes necessary to consider a possible change in the extinction coefficient of the solid polymeric matrix $\left(\mathrm{K}_{\omega}\right)$ produced by the inclusion of the nanoclays, in order to have a better agreement between model and experimental values. It has been proved that the cells size and mass fraction on struts variations are not enough to completely explain the changes produced in the radiation conduction term. A change in the solid material properties should be considered: therefore we should assume that nanoclays play a role as IR-blockers in polyurethane foams.

- Conduction through the solid phase: Nanoclays presence could affect the conductivity of the solid phase. Differences between experimental and theoretical data observed in Figures 5.24 and 5.25 could be due to this variation. A different trend between 
experimental and theoretical values is observed: models present a minimum for thermal conductivity at 3 or even 5 wt\% nanoclays concentration, whereas for experimental data the minimum is reached at $1 \mathrm{wt} \%$. Other properties with a considerable influence on the thermal conductivity also present a minimum for $3 \%$ wt nanoclays concentration, as the cell size.

Considering a variation of the conduction through the solid phase is a possible way to explain this difference in behaviour. As it was carried out for thermal conductivity of the gas phase, theoretical values of the solid polymer can be extrapolated. Figure 5.29 shows how the calculated values (the value was calculated to obtain a perfect match between experimental and theoretical values) vary with the amount of nanoclays with respect to the pure material. A clear growing dependence with the nanoclays concentration is observed for 3 and $5 \% w t$. For $0.5 \% w t$, and even more for $1 \%$ wt nanoclays concentration, a reduction is observed. This increase in the cconductivity of the solid material could be related with the creation of a percolation network for clays contents around $3 \%$ by weight ${ }^{45-47}$. Rheological characterization could help to clarify this subject ${ }^{48,}{ }^{49}$, showing where the percolation threshold is located for these materials.

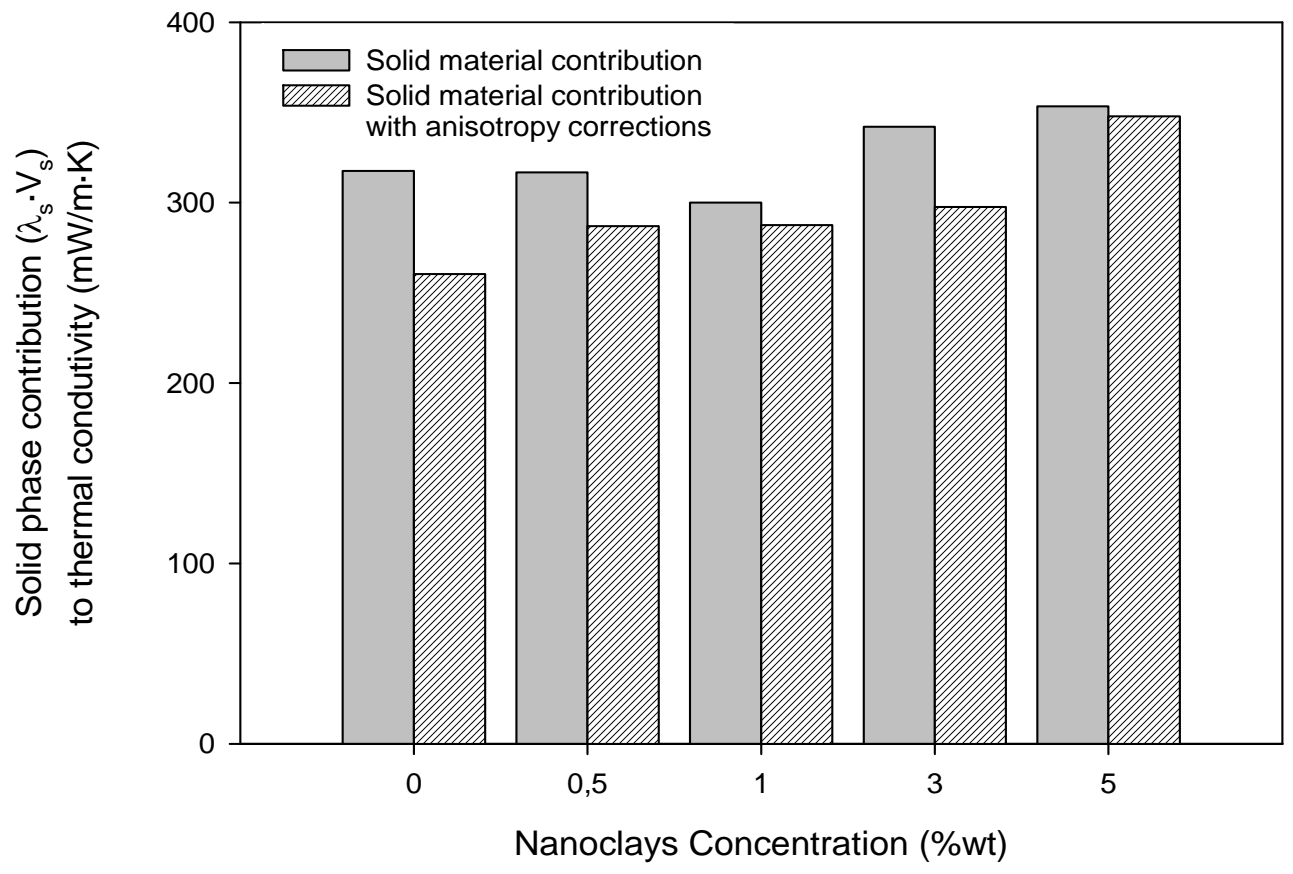

FIGURE 5.29. Solid polymer conductivity contribution $\left(\lambda_{s} \cdot V_{s}\right)$ calculated using Eq. 23. 
Finally, assuming a good approach of the Glicksman model to the experimental data, it is possible to assume that the changes produced in thermal conductivity by the inclusion of nanoclays in different concentrations are due not only to morphological changes in the cellular structure, as the cell modification in size, mass fraction in struts and anisotropy, but also to changes in the thermal properties of the polymeric matrix and in the extinction coefficient of the solid polymer.

\section{5.- Summary and conclusions}

This chapter have been focused on evaluating the effect of nanoclays concentration on the structure and properties of polyurethane foams filled with nanoclays. The different properties and the main results obtained are:

- Density measurements: the inclusion of nanoparticles in polyurethane foams produced a measurable change in final foams density. A small reduction for the lower value of the infused nanoclays was measured, however in general terms the macroscopic density tends to increase when nanoclays are added. Similarly to the case of the dispersion techniques study, the reason for this slight growth could be connected with a higher viscosity of the initial blend when clays are infused, combined with the fact that nanofillers density (Cloisite $30 \mathrm{~B}-1980 \mathrm{~kg} / \mathrm{m}^{3}$ ) is usually higher than that of the reference foam (around $50 \mathrm{~kg} / \mathrm{m}^{3}$ ).

- Cell size: The presence of nanoclays reduces the average cell size. This cell size reduction has been explained by an increase in the nucleation due to the nanoclays presence. Cell size presents a reducing general trend with nanoclays concentration until 3\%wt, which presents the highest reduction (24\% reduction respect pure polyurethane foam). A small increase in cell size is observed for the highest clays concentration ( $5 \mathrm{wt} \%, 21 \%$ of cell size reduction respect pure material).

- Cellular anisotropy: It was observed a variation in the anisotropy of the cellular structure with the nanoclays concentration. The pure foams and the materials with low filling amounts have an anisotropic cellular structure, with cells oriented in the growing direction. As the amount of clays is increased a general trend is observed with a reduction in the anisotropy value.

- Open cell content: Open cell content does not present significant changes by the nanoclays presence, with similar values to the pure material for the nanoclays infused 
foams. An average value of $6.5 \%$ was observed for the pure materials and $0.5 \%$ wt nanoclays concentration samples, while an average value around $8.5 \%$ was observed for the rest of the samples.

- Mass fraction in the struts: Considerable changes were observed in the mass fraction in the struts with the increase of nanoclays in: from a value of 0.67 for the pure material, small variations were observed until $1 \mathrm{wt} \%$ of nanoclays $(0.62$ for $0.5 \%$ wt and 0.66 for $1 w t \%)$, increasing then to 0.78 for $3 w t \%$ and to 0.76 for $5 w t \%$. These considerable changes in the mass distribution in the cellular structure have clear effects on the extinction coefficient and thermal conductivity. The origin of the modification of $f_{s}$ could be related to changes produced in the viscosity of the polyolnanoclays mixture as the nanoclays amount is increased, fact which can be vital during the cell formation and stabilization. Another possible explanation of this result is associated with a modification of the reaction kinetics. The clays could modify the blowing reaction kinetics, the gelling reaction kinetics or both. Initial experiments on this area have showed a delay of the reactions kinetics when clays are added.

- Cell size distribution: The normalized standard deviation (NSD) of the cell size distributions experiences a clear increase when clays are infused. In fact, a bimodal cell size distribution was detected for high amounts of clays (0.62 of NSD value for $5 \mathrm{wt} \%$, clearly higher than the 0.20 measured for pure material). The asymmetry coefficient showed an increase when the clays were added.

- Nucleation efficiency: nucleation efficiency of nanoclays was studied for the different nanoclay concentrations, showing a clear reduction as the amount of nanoclays was increased. Comparing these results with the observed in the studied bibliography, it is possible to conclude that poor nucleation efficiency has been achieved.

- Compression properties: the presence of nanoclays in polyurethane foams has supposed not only a small improvement of the elastic modulus (around $12 \%$ of increase with respect to the pure material for $3 w t \%$ nanoclays), but also a decrease of the compression strength (between 1 to $5 \%$ of decrease with respect to the pure material). A correlation with the possible interaction of nanoclays and the polyurethane matrix has been proposed: a destruction of $\mathrm{H}$-bonds between chains (which have a significant impact on the mechanical properties of unfilled polyurethane foams) by the nanoclays presence could the responsible of the slight improvements or 
even the reduction $(\sigma)$ of the mechanical. The increase in the nanoclays added has not supposed an increase of the compression properties, even a reduction of them.

- Flexural properties: a decrease of the deformation at maximum strength has been observed, with more than a $50 \%$ reduction with respect to the pure material for the higher clays concentrations. Flexural modulus presents an initial increase of $12 \%$ with respect to the pure material for the lower concentration (0.5\%wt.), lower improvements for 1 and $3 \mathrm{wt} \%$ concentrations and a $20 \%$ increase for the 5\%wt sample. Flexural strength presents a significant decrease in its absolute values by the addition of nanoclays (from $0.73 \mathrm{MPa}$ for pure material to an average value of 0.65 MPa for the nanoclays infused materials).

- Shear properties: small changes has been observed in the shear modulus with the inclusion of nanoclays, with a clear difference between plane perpendicular to the foaming direction (higher value) and its perpendicular (lower value). It has been observed a correlation between the cellular anisotropy measured with SEM technique and the measured shear modulus.

- Improving the thermal conductivity of polyurethane foams by using nanoclays as nucleating agents and IR-blockers: Time evolution of the different samples was studied, showing an increase of this property as the diffusion of the blowing agent $\left(\mathrm{CO}_{2}\right)$ from the cells to the atmosphere was produced. After 12 days from the material production, a stable value was measured, reaching the stationary state. For the final values of thermal conductivity in stationary state, it was observed a reduction with the addition of nanoclays. This improvement can be considered as a secondary effect of the cell size reduction (thermal conductivity presents a high dependence with the cell size) that has been produced by the addition of nanoclays. The higher decrease of the thermal conductivity was observed for $1 \mathrm{wt} \%$ of nanoclays. The increase of the amount of nanoclays further than $1 \mathrm{wt} \%$ did not produce a higher reduction of the thermal conductivity; moreover, worse results than for the pure material were obtained. Higher reduction of the cell size was observed with higher amounts of nanoclays, but the thermal conductivity reduction stops at $1 \mathrm{wt} \%$. In order to have a better understanding of this behaviour, a detailed modelling was conducted. It was also measured the temperature evolution of the thermal conductivity for the different samples, observing a linear increase with the temperature for all the materials studied. The slope of the curve, consequence of the linear fit, shows a decrease with the 
amount of nanoclays. As the cell size is related with the inclusion of nanoclays, this change can be explained taking into account the change in the cell size.

- Modelling the thermal conductivity of the developed foams, using as a basis the experimental determination of the extinction coefficient of the foams: Besides cell size, extinction coefficient and the percentage of mass in the struts are critical parameters which experimented changes with the modifications in the nanoclays concentration and that have a clear influence over the thermal conductivity. Thereby, the modelling of the different heat transfer mechanisms involved has helped to better understand the thermal behaviour of the polyurethane-nanoclays system. For the range of cell sizes under study there are three different contributions to the thermal conductivity: conduction through the gas, thermal radiation and conduction along the cell walls and struts of the solid polymer. These are the results for each of them:

Thermal conductivity through the gas phase: it is the most significant mechanism over the final value of the thermal conductivity (71-72\% contribution). This contribution does not present significant changes due to the nanoclays addition. Moreover, the biggest change observed in this term is due to the effect of the foaming gas ( $\mathrm{CO} 2$ ) diffusion and it substitution by atmospheric air.

Thermal radiation: this contribution experiments clear changes by the nanoclays presence. Considering Rosseland model (eq. 5.21), this term is deeply related with changes in the extinction coefficient (higher extinction coefficient implies lower conductivity by radiation). In turn, accepting Glicksman model (eq. 5.14), extinction coefficient is also related with the cell size, density, mass fraction in struts and the optical properties of the solid phase. Comparing experimental values for extinction coefficient and theoretical values taking into account the changes produced by nanoclays (cell size reduction and variation in mass fraction in struts), both present a maximum for $3 w t \%$ nanoclays, but completely different values (table 5.13). The cells size and mass fraction in struts variations are not enough to completely explain the changes produced in the radiation conduction term: a possible change in the optical properties of the solid material has been considered. This could be related with the reflexion/absorption of IR radiation by the clay platelets, which seem to contribute from this point of view.

Conduction through the solid phase: for this term, experimental data do not agree with the modelling data. The creation of a percolation network by the nanoclays 
could be the reason; this will increase the thermal conductivity of the solid phase. This network could have a percolation threshold between 1 and 3wt\%, so its effect would begin to be detected for a content of $3 w t \%$ or higher.

In summary, the modelling carried out allows concluding that the changes produced in thermal conductivity by the inclusion of nanoclays in different concentrations are due to a combination of morphological changes in the cellular structure (as the cell size and mass fraction in struts), changes in the optical properties of the polymeric matrix (clay acting as IR-blockers) and modifications of the thermal conductivity of the solid phase (clays increasing this conductivity). 
Chapter 5: Nanoclays Concentration Effects

${ }^{1}$ K. Liang, ShQ. Shi, Nanoclay filled soy-based polyurethane foam, Journal of Applied Polymer Science, 119(3):1857-63, (2011)

${ }^{2}$ Ł. Piszczyk, M. Strankowski, M. Danowska, J. T. Haponiuk, M. Gazda, Preparation and characterization of rigid polyurethane-polyglycerol nanocomposite foams, European Polymer Journal, 48(10), 1726-1733, (2012)

3 J. Y. Lee, H. K. Lee, Characterization of organobentonite used for polymer nanocomposites, Materials Chemistry and Physics, 85(2), 410-415, (2004)

${ }^{4}$ D. García-López, I. Gobernado-Mitre, J. F. Fernández, J. C. Merino, J. M. Pastor, Influence of clay modification process in PA6-layered silicate nanocomposite properties, Polymer, 46(8), 2758-2765, (2005)

${ }^{5}$ M. Thirumal, D. Khastgir, N. K. Singha, B. S. Manjunath, Y. P. Naik, Effect of foam density on the properties of water blown rigid polyurethane foam, Journal of Applied Polymer Science, 108(3), 1810-1817, (2008)

${ }^{6}$ S. Pardo-Alonso, E. Solórzano, S. Estravís, M. A. Rodríguez-Perez, J. A. de Saja, In situ evidence of the nanoparticle nucleating effect in polyurethane-nanoclay foamed systems, Soft Matter, 8(44), 11262-11270 (2012)

${ }^{7}$ S. Pardo-Alonso, E. Solórzano, L. Brabant, P. Vanderniepen, M. Dierick, L. Van Hoorebeke, (3d) Analysis of the Progressive Modification of the Cellular Architecture in Polyurethane Nanocomposite Foams via X-Ray Microtomography, European Polymer Journal, 49(5), 9991006, (2013)

${ }^{8}$ H. Bahrambeygi, A. Rabbi, K. Nasouri, A. M. Shoushtari, M. R. Babaei, Morphological and structural developments in nanoparticles polyurethane foam nanocomposite's synthesis and their effects on mechanical properties, Advances in Polymer Technology, 32(S1), E545-E555, (2012)

${ }^{9}$ G. Harikrishnan, T. U. Patro, D. V. Khakhar, Polyurethane foam-clay nanocomposites: nanoclays as cell openers, Industrial \& Engineering Chemistry Research, 45(21), 7126-7134, (2006)

${ }^{10}$ R. Gu, M. M. Sain, Effects of Wood Fiber and Microclay on the Performance of Soy Based Polyurethane Foams, Journal of Polymers and the Environment, 21(1), 30-38 (2012) 
${ }_{11}$ M. Bernal, M. A. Lopez-Manchado, R. Vedejo, In situ foaming evolution of flexible polyurethane foam nanocomposites, Macromolecular Chemistry and Physics, 212(9), 971-979 (2011)

${ }^{12}$ A.C. Draye, J.J. Tondeur, Kinetic study of organotin-catalyzed alcohol-isocyanate reactions: Part 1: Inhibition by carboxylic acids in toluene, Journal of Molecular Catalysis A: Chemical, 138(2), 135-144, (1999)

${ }^{13}$ M. Bernal, M. Martin-Gallego, L. J. Romasanta, A. C. Mortamet, M. A. López-Manchado, A. J. Ryan, R. Verdejo, Effect of hard segment content and carbon-based nanostructures on the kinetics of flexible polyurethane nanocomposite foams, Polymer, 53(19), 4025-4032 (2012)

${ }^{14}$ P. Spitael, C. W. Macosko, R. B. McClurg, Block copolymer micelles for nucleation of microcellular thermoplastic foams, Macromolecules, 37(18), 6874-6882 (2004)

${ }^{15}$ L. J. Gibson, M. F. Ashby, Cellular solids: structure and properties, Pergamon Press, Oxford, (1988)

${ }^{16}$ M. A. Schuetz, L. R. Glicksman, A basic study of heat transfer through foam insulation, Journal of Cellular Plastics, 20(2), 114-121, (1984)

${ }^{17}$ M. Modesti, A. Lorenzetti, S. Besco, Influence of nanofillers on thermal insulating properties of polyurethane nanocomposites foams, Polymer Engineering \& Science, 47(9), 1351-1358, (2007)

${ }^{18}$ M.A. Rodríguez-Pérez, J. I. González-Peña, N., Witten, J. A. de Saja, The effect of cell size on the physical properties of crosslinked closed cell polyethylene foams produced by a high pressure nitrogen solution process, Cellular Polymers, 21(3), 165-194, (2002)

${ }^{19}$ L.R. Glicksman, M. Torpey, Proceedings of PolyurethaneWorld Congress, Aachen, Germany, (1987)

${ }^{20}$ L. R. Glicksman, A. Marge; J. D. Moreno, Developments in Radiative Heat Transfer, 203, 45$54,(1992)$

${ }^{21}$ D. Doermann, J.F. Sacadura, Heat transfer in open cell foam insulation. Journal of heat transfer, 118(1), 88-93, (1996)

${ }^{22}$ L. R. Glicksman, In Low Density Cellular Plastics: Physical Basis of Behaviour, Hilyard, N. C., Cunningham, A., Eds., Chapman \& Hall: London, Chapter 5, (1994)

${ }^{23}$ H.R.N. Jones, In Radiation Heat Transfer, Oxford Science: Oxford, (2000) 
Chapter 5: Nanoclays Concentration Effects

${ }^{24}$ J. W. Wu, W. F. Sung, H.S. Chu, Thermal conductivity of polyurethane foams, International journal of heat and mass transfer, 42 (12), 2211-2217, (1999)

${ }^{25}$ C. J. Tseng, K. T. Kuo, Thermal radiative properties of phenolic foam insulation, Journal of Quantitative Spectroscopy and Radiative Transfer, 72(4), 349-359, (2002)

${ }^{26}$ R. Siegel, J. R. Howell, In Thermal Radiation Heat Transfer, Taylor \& Francis: London, (1992)

${ }^{27}$ F. Kreith, M. S. Bohn, In Principios de Transferencia de Calor, 6th ed., Thomson Paraninfo: Madrid, Spain, (2002)

28 J. P. Holman, In Heat Transfer, 9th ed.; McGraw-Hill: New York, (2002)

${ }^{29}$ M. Modesti, A. Lorenzetti, An experimental method for evaluating isocyanate conversion and trimer formation in polyisocyanate-polyurethane foams, European polymer journal, 37(5), 949-954, (2001)

${ }^{30}$ M. M. Coleman, D. J. Skrovanek, J. Hu, P.C. Painter, Hydrogen bonding in polymer blends. 1. FTIR studies of urethane-ether blends, Macromolecules, 21(1), 59-65, (1988)

31 S. Pavlidou, C.D. Papaspyrides, A review on polymer-layered silicate nanocomposites, Progress in polymer science, 33(12), 1119-1198, (2008)

${ }^{32}$ D. Baillis, M. Arduini-Schuster, J. F. Sacadura, Identification of spectral radiative properties of polyurethane foam from hemispherical and bi-directional transmittance and reflectance measurements, Journal of Quantitative Spectroscopy and Radiative Transfer, 73(2), 297-306, (2002)

33 L. R. Glicksman, Heat transfer and ageing of cellular foam insulation, Cellular polymers, 10(4), 276-293, (1991)

${ }^{34}$ A. Cunningham, D. Sparrow, Rigid polyurethane foam: What makes it the most effective insulant?, Cellular polymers, 5(5), 327-342, (1986)

${ }^{35}$ C. J. Tseng, M. Yamaguchi, T. Ohmori, Thermal conductivity of polyurethane foams from room temperature to $20 K$, Cryogenics, 37 (6), 305-312, (1997)

36 J. Kuhn, H. P. Ebert, M. C. Arduini-Schuster, D. Büttner, J. Fricke, Thermal transport in polystyrene and polyurethane foam insulations, International Journal of Heat and Mass Transfer, 35(7), 1795-1801, (1992)

37 M.A. Rodríguez-Pérez, O. Alonso, J. Souto, J. A. De Saja, Thermal conductivity of physically crosslinked closed cell polyolefin foams, Polymer Testing, 16(3), 287-298, (1997) 
${ }^{38}$ G. W. Ball, Proceeding of IOM Polyurethanes Conference 1994, 10, 257 (1994)

${ }^{39}$ O. A. Almanza, M. A. Rodríguez-Pérez, J. A. De Saja, Prediction of the radiation term in the thermal conductivity of crosslinked closed cell polyolefin foams, Journal of Polymer Science Part B: Polymer Physics, 38(7), 993-1004, (2000)

40 X. Cao, L. J. Lee, T. Widya, C. Macosko, Polyurethane/clay nanocomposites foams: processing, structure and properties, Polymer, 46(3), 775-783, (2005)

${ }^{41}$ A. Lorenzetti, D. Hrelja, S. Besco, M. Roso, M. Modesti, Improvement of nanoclays dispersion through microwave processing in polyurethane rigid nanocomposite foams, Journal Of Applied Polymer Science, 115(6), 3667-3674, (2010)

42 D. Eaves, Handbook of Polymer Foams, Rapra Technology, United Kingdom, (2004)

${ }^{43}$ E. Solórzano, Espumas de Aluminio: Proceso de Espumado, Estructura Celular y Propiedades, PhD Work, University of Valladolid, (2008)

44 R.C. Read, J.M. Prausnitz, T.K. Sherwood, The properties of gases and liquids, 3rd edn.,McGraw-Hill, NY, (1977)

${ }^{45}$ F. H. Gojny, M. H. G. Wichmann, B. Fiedler, I. A. Kinloch, W. Bauhofer, A. H. Windle, K. Schulte, Evaluation and identification of electrical and thermal conduction mechanisms in carbon nanotube/epoxy composites, Polymer, 47(6), 2036-2045, (2006)

46 J. N. Coleman, S. Curran, A.B. Dalton, A.P. Davey, B. McCarthy, W. Blau, R. C. Barklie, Percolation-dominated conductivity in a conjugated-polymer-carbon-nanotube composite, Physical Review B, 58(12), R7492-R7495, (1998)

${ }^{47}$ C. Lin, D.D.L. Chung, Nanoclay Paste as a Thermal Interface Material for Smooth Surfaces, Journal of electronic materials, 37(11), 1698-1709, (2008)

48 I. Novák, I. Krupa, I. Chodák, Relation between electrical and mechanical properties in polyurethane/carbon black adhesives, Journal of materials science letters, 21(13), 1039-1041, (2002)

${ }^{49}$ R. Krishnamoorti, K. Yurekli, Rheology of polymer layered silicate nanocomposites, Current Opinion in Colloid \& Interface Science, 6(5), 464-470, (2001) 

CHAPTER 6:

CONCLUSIONS AND FUTURE WORK 



\section{6.- CONCLUSIONS AND FUTURE WORK}

During the development of the present work, a complete study of a foamed polyurethane system containing nanoclays has been performed: the effect on the structure and properties of different dispersion techniques and different amount of nanoclays has been studied. For this purpose, rheological studies of the nanoclays dispersion in the polyol component were performed in order to characterise the different dispersion techniques, extending this study to different polyurethane commercial formulations. These studies allowed selecting the most sensitive formulation to the dispersion techniques employed, and then this blend was used for the production and characterization of foamed polyurethane samples without and with nanoclays, dispersed with different techniques and in different concentrations.

According to the objectives initially presented, and in correspondence to the order in which they were presented, the present work allows obtaining the following conclusions for both methodological and scientific objectives:

\section{Methodological Objectives}

- Setting up of the polyurethane foams production technique: a procedure for the production of polyurethane foams and polyurethane foams containing nanoclays has been set up. Various facilities have been purchased and their use optimized. Among them, an ultrasound probe, a low shear mixer and a high-shear mixer. To complete this activity other sub-objectives were fulfilled:

Selection of polyurethane formulations: the polyol blends from three different formulations were studied with rheological techniques for the selection of the most sensitive formulation with respect to the different dispersion techniques employed. Due to the high sensitivity of the low viscosity blend, this material was selected for the production and characterization of rigid polyurethane-nanoclays foams

Selection of nanoparticles: Cloisite 30B nanoclays were selected due to their specific functionalization for polyurethane reagents, and their use in the related literature of polyurethane nanocomposites foams. 
Optimization of the dispersion methods: Three different dispersion techniques (hand mixing, low shear mixing and ultrasonication) have been used and their dispersion capabilities analysed.

Optimization of the processing parameters: Different parameters have been taken into account to establish a robust and reproducible process to produce foamed nanocomposites based on polyurethane. Some of them are: mixing time, temperature, moisture, size of the sample and so on.

- Optimization of the polyurethane characterization techniques: The experimental techniques used at CellMat for the characterization of polymer foams have been adapted to obtain a reliable and precise characterization of rigid polyurethane foams and rigid polyurethane foams reinforced with nanoclays.

\section{Scientific Objectives}

- Evaluating in detail the effect of the dispersion quality of the clays in the polyol blend on the structure and properties of polyurethane foams filled with nanoclays: Samples with a constant amount of nanoclays (3\%wt) dispersed in the polyol with different dispersion techniques (hand mixing, low shear mixing and ultrasonication) were manufactured in order to characterise the effect of the different techniques on their density, structure, mechanical and thermal properties. The formulation with a lower viscosity of the polyol was the most sensitive to the different dispersion techniques employed. The measured properties, besides the exfoliation characterization, showed that even for the powerless dispersion techniques (hand mixing), nanoclays intercalation was produced. Our analysis indicated that low shear mixing presented the best balance between mixing time, power used and final properties. A detailed review of the different properties studied is summarized in the following paragraphs:

$>$ Density measurements: the inclusion of nanoparticles in polyurethane foams produced a measurable change in final foams density. Nanofillers inclusion produced a small density reduction only in the low shear mixing technique foam, but in general terms the 
macroscopic density tends to increase when nanoclays are added. The reason for this slight growth could be connected with a higher viscosity of the initial blend when clays are infused, combined with the fact that nanofillers density (Cloisite $30 \mathrm{~B}-1980 \mathrm{~kg} / \mathrm{m}^{3}$ ) is usually higher than that of the reference foam (around $50 \mathrm{~kg} / \mathrm{m}^{3}$ ).

$>$ Cell size: The presence of nanoclays reduces the average cell size. Regarding to the different dispersion techniques, no clear effect on the cell size has been observed, obtaining an average reduction close to $10 \%$ with respect to the pure material.

> Cellular anisotropy: no clear effects on cellular anisotropy were obtained (around a 10\% variation with respect to the pure material) for the different dispersion techniques.

$>$ Open cell content: Open cell content does not present significant changes by the nanoclays presence, with similar values for nanoclays infused foams than for pure materials. Measured values were always under $10 \%$ independently from the dispersion technique employed.

Cell size distribution: The normalized standard deviation (NSD) of the cell size distributions experienced a clear increase (approx. from 0.2 for pure material to 0.3 for the different techniques). The asymmetry coefficient presented a small reduction with respect to the pure material.

Nucleation efficiency: nucleation efficiency of nanoclays was studied for the different dispersion techniques, showing a similar value to what it is found in the studied bibliography.

Nanoclays intercalation: X-ray diffraction experiments performed over the polyurethane samples produced with different formulations showed an intercalation of the nanoclays in the polymeric matrix. This effect was observed for all the dispersion methods used, showing that intercalation can be achieved even for the poorest dispersion (high viscosity blend). DMA studies over the samples manufactured with BASF material and different dispersion techniques corroborated this result, showing a clear effect of nanoclays over the polymeric chains 
mobility, as it can be concluded by the increase in $T_{g}$ and the decrease of $\tan \delta$.

Compression properties (relative to the square of the density): the presence of nanoclays in polyurethane foams has supposed a small increase of the elastic modulus (not correlated with the dispersion quality) and a decrease of the compression strength (near to $6 \%$ with respect to the pure material for the ultrasonication dispersion technique). These effects seem to be connected with two possible facts: the modification of the cellular structure, with an increase in the width of the cell sizes distribution, and the relationship between the dispersion quality of the particles and a possible chemical interaction of nanoclays and polyurethane matrix. This interaction implies a destruction of $\mathrm{H}$-bonds between polymeric chains (which have a significant impact on the mechanical properties of unfilled foams) by the nanoclays presence. Then, as a powerful dispersion technique implies a better dispersion, a powerful dispersion technique will also imply a higher interaction between the nanofillers and the PU matrix, and this will result in worse mechanical properties. As it has been proven that intercalation of the nanoclays is achieved independently from the dispersion technique employed, a better dispersion will imply a higher filler-matrix interaction and as consequence a reduction of the matrix properties.

Shear properties: small changes has been observed in the value of the shear modulus with the inclusion of nanoclays, and a clear difference between foaming direction value (higher value) and perpendicular to foaming direction value (lower value) has been observed, showing the importance of anisotropy for the analysed materials.

Thermal conductivity: Thermal conductivity has been reduced by the addition of nanoclays. This reduction is an expected result due to the relationship between cell size and thermal conductivity. An increase of the extinction coefficient has been observed, but it does not completely explain the changes in the thermal conductivity. Other factors as the open cell content have an influence over the observed changes. 
- Evaluating in detail the effect of the clays content on the cellular structure, thermal and mechanical properties of the foamed composites: Samples with different amounts of nanoclays $(0.5,1,3$ and $5 \% \mathrm{wt})$, dispersed in the polyol with low shear mixing technique, were manufactured in order to characterise the effect of the different techniques on the density, structure, mechanical and thermal properties of polyurethane foams. The main results obtained are summarized in the following paragraphs:

Density measurements: the inclusion of nanoparticles in polyurethane foams produced a measurable change in final foams density. A small reduction for the lower value of the infused nanoclays was measured, however in general terms the macroscopic density tends to increase when nanoclays are added. Similarly to the case of the dispersion techniques study, the reason for this slight growth could be connected with a higher viscosity of the initial blend when clays are infused, combined with the fact that nanofillers density (Cloisite 30B - 1980 $\mathrm{kg} / \mathrm{m}^{3}$ ) is usually higher than that of the reference foam (around 50 $\mathrm{kg} / \mathrm{m}^{3}$ ). Regarding to the small decrease for lower concentrations, despite nanoclays were dehydrated previously to their incorporation and dispersion in polyurethane polyol, this do not always guarantee the complete absence of water in the nanoclays that could act as chemical blowing agent. This amount of water must be considerably small and could be compensated by the increase of the viscosity as the amount of clays is increased.

$>$ Cell size: The presence of nanoclays reduces the average cell size. This cell size reduction has been explained by an increase in the nucleation due to the nanoclays presence. Cell size presents a general reducing trend with nanoclays concentration until $3 \% \mathrm{wt}$, which presents the highest reduction $(24 \%$ reduction with respect to the pure polyurethane foam). An increase in cell size is observed for highest concentration ( $5 \%$ wt sample, with $21 \%$ of cell size reduction with respect to the pure material).

Cellular anisotropy: It was observed a variation in the anisotropy of the cellular structure with the nanoclays concentration. In general the cells were larger in the growing direction of the foam. For instances the 
anisotropy ratio was 1.69 for the pure material. As the amount of clays is increased a general trend is observed, with a reduction in the anisotropy value.

$>$ Open cell content: Open cell content does not present significant changes by the nanoclays presence, with similar values to the pure material for the nanoclays infused foams. An average value of $6.5 \%$ was observed for pure and $0.5 \%$ wt nanoclays concentration samples, while an average value around $8.5 \%$ was observed for the rest of the samples.

Mass fraction in the struts: Considerable changes were observed in the mass fraction in the struts with the addition of nanoclays in the foams: from a value of 0.67 for the pure material, small variations were observed until $1 \% w t$ of nanoclays ( 0.62 for $0.5 \% w t$ and 0.66 for $1 \%$ ), increasing this value to 0.78 for $3 \%$ and to 0.76 for $5 \%$. This significant change of the mass distribution in the cellular structure has clear effects on the extinction coefficient and thermal conductivity. The origin of these changes could be related to modifications produced in the viscosity of the polyol-nanoclays mixture as the nanoclays amount is increased, fact which can be very important during the cell formation and stabilization. Another possible explanation of this result is associated with a modification of the reaction kinetics. The clays could modify the blowing reaction kinetics, the gelling reaction kinetics or both. Initial test by using FTIR on the reaction kinetics when clays are added indicate that the reaction rates are reduced.

$>$ Cell size distribution: The normalized standard deviation (NSD) of the cell size distribution experienced a clear increase when the nanoparticles are added. In fact, a bimodal cell size distribution was detected for high amounts of clays (0.62 of NSD value for $5 \% \mathrm{wt}$, against 0.20 for pure material). In addition, the asymmetry coefficient also increases when the particles are infused.

Nucleation efficiency: nucleation efficiency of nanoclays was studied for the different nanoclay concentrations, showing a clear reduction as 
the amount of nanoclays was increased. In general, the nucleation efficiency of the particles was small.

Compression properties: the presence of nanoclays in polyurethane foams has supposed not only a small improvement of the elastic modulus (around $12 \%$ of increase with respect to the pure material for $3 w t \%$ nanoclays), but also a decrease of the compression strength (between 1 to $5 \%$ of decrease with respect to the pure material). A correlation with the possible interaction of nanoclays and the polyurethane matrix has been proposed: a destruction of $\mathrm{H}$-bonds between chains (which have a significant impact on the mechanical properties of unfilled polyurethane foams) by the nanoclays presence could the responsible of the slight improvements or even the reduction $(\sigma)$ of the mechanical. The increase in the nanoclays added has not supposed an increase of the compression properties, even a reduction of them.

Flexural properties: a decrease of the deformation at maximum strength has been observed, with more than a $50 \%$ reduction with respect to the pure material for the higher clays concentrations. Flexural modulus presents an initial increase of $12 \%$ with respect to the pure material for the lower concentration (0.5\%wt.), lower improvements for 1 and 3 wt\% concentrations and a 20\% increase for the $5 \%$ wt sample. Flexural strength presents a significant decrease in its absolute values by the addition of nanoclays (from $0.73 \mathrm{MPa}$ for pure material to an average value of $0.65 \mathrm{MPa}$ for the nanoclays infused materials).

- Shear properties: small changes has been observed in the shear modulus with the inclusion of nanoclays, with a clear difference between plane perpendicular to the foaming direction (higher value) and its perpendicular (lower value). It has been observed a correlation between the cellular anisotropy measured with SEM technique and the measured shear modulus

- Improving the thermal conductivity of polyurethane foams by using nanoclays as nucleating agents and IR-blockers: Time evolution of the different samples 
was studied, showing an increase of this property as the diffusion of the blowing agent ( $\mathrm{CO} 2)$ from the cells to the atmosphere was produced. After 12 days from the material production, a stable value was measured, reaching the stationary state. For the final values of thermal conductivity in stationary state, it was observed a reduction with the addition of nanoclays. This improvement can be considered as a secondary effect of the cell size reduction (thermal conductivity presents a high dependence with the cell size) that has been produced by the addition of nanoclays. The higher decrease of the thermal conductivity was observed for $1 \mathrm{wt} \%$ of nanoclays. The increase of the amount of nanoclays further than $1 \mathrm{wt} \%$ did not produce a higher reduction of the thermal conductivity; moreover, worse results than for the pure material were obtained. Higher reduction of the cell size was observed with higher amounts of nanoclays, but the thermal conductivity reduction stops at $1 \mathrm{wt} \%$. In order to have a better understanding of this behaviour, a detailed modelling was conducted. It was also measured the temperature evolution of the thermal conductivity for the different samples, observing a linear increase with the temperature for all the materials studied. The slope of the curve, consequence of the linear fit, shows a decrease with the amount of nanoclays. As the cell size is related with the inclusion of nanoclays, this change can be explained taking into account the change in the cell size.

- Modelling the thermal conductivity of the developed foams, using as a basis the experimental determination of the extinction coefficient of the foams: Besides cell size, extinction coefficient and the percentage of mass in the struts are critical parameters which experimented changes with the modifications in the nanoclays concentration and that have a clear influence over the thermal conductivity. Thereby, the modelling of the different heat transfer mechanisms involved has helped to better understand the thermal behaviour of the polyurethane-nanoclays system. For the range of cell sizes under study there are three different contributions to the thermal conductivity: conduction through the gas, thermal radiation and conduction along the cell walls and struts of the solid polymer. These are the results for each of them:

Thermal conductivity through the gas phase: it is the most significant mechanism over the final value of the thermal conductivity (71-72\% contribution). This contribution does not present significant changes 
due to the nanoclays addition. Moreover, the biggest change observed in this term is due to the effect of the foaming gas (CO2) diffusion and it substitution by atmospheric air.

$>$ Thermal radiation: this contribution experiments clear changes by the nanoclays presence. Considering Rosseland model (eq. 5.21), this term is deeply related with changes in the extinction coefficient (higher extinction coefficient implies lower conductivity by radiation). In turn, accepting Glicksman model (eq. 5.14), extinction coefficient is also related with the cell size, density, mass fraction in struts and the optical properties of the solid phase. Comparing experimental values for extinction coefficient and theoretical values taking into account the changes produced by nanoclays (cell size reduction and variation in mass fraction in struts), both present a maximum for $3 \mathrm{wt} \%$ nanoclays, but completely different values (table 5.13). The cells size and mass fraction in struts variations are not enough to completely explain the changes produced in the radiation conduction term: a possible change in the optical properties of the solid material has been considered. This could be related with the reflexion/absorption of IR radiation by the clay platelets, which seem to contribute from this point of view.

Conduction through the solid phase: for this term, experimental data do not agree with the modelling data. The creation of a percolation network by the nanoclays could be the reason; this will increase the thermal conductivity of the solid phase. This network could have a percolation threshold between 1 and $3 w t \%$, so its effect would begin to be detected for a content of $3 w t \%$ or higher.

In summary, the modelling carried out allows concluding that the changes produced in thermal conductivity by the inclusion of nanoclays in different concentrations are due to a combination of morphological changes in the cellular structure (as the cell size and mass fraction in struts), changes in the optical properties of the polymeric matrix (clay acting as IR-blockers) and modifications of the thermal conductivity of the solid phase (clays increasing this conductivity). 
The study of the different concentrations of nanoclays has shown that the inclusion of these nanofillers requires reaching an equilibrium between different factors, as nanoparticles concentration, dispersion and exfoliation. Without this equilibrium it is easy to obtain a final foam with worse properties than the pure material. It is necessary a low nanoparticles concentration, $1 \mathrm{wt} \%$ or less, in order to avoid an increase of the mass fraction in the struts and the formation of a percolation network, effects that have a negative consequence on thermal properties. Moreover, it has been observed that mechanical properties present a maximum for values around 3\%wt of nanoclays concentration. For this characteristic it would be important to have a relatively good dispersion of the nanoparticles to obtain higher nucleation rates, but it is also important to control this good dispersion to promote a higher interaction between the polymeric matrix and the nanoclays, which reduce final mechanical properties.

The obtained results have two different implications. On one hand, it is easy to achieve good results with the inclusion of a low wt \% of nanoclays without the use of a powerful, timespending dispersion technique (ultrasounds are not needed). On the other hand, the small improvement, or even the decrease, on the final mechanical properties obtained for the higher nanoclays concentrations shows that the interaction between matrix and nanofillers plays an essential role in the PU rigid foams under study. As the polyurethane matrix $\mathrm{H}$-bonds alteration could be the reason, it is necessary to optimize the nanoparticles aspect ratio and the surface chemistry to the polymeric matrix employed to achieve higher improvements, at least from a mechanical point of view. Other properties (such as thermal conductivity) related with morphological characteristics (such as cell size) are suitable to be optimized by the nanoclays used in this research, since nanoclays are able to reduce cell size with a simple mixing technique.

Another aspect that could play a key role is the modification of the kinetics of the chemical reactions (blowing and gelling) by the addition of these types of particles. Understanding these effects should be very helpful to make a better use of nanoparticles.

In conclusion, a correct understanding of the different alterations produced are necessary not only to find the optimal nanoparticle and concentration for this specific polyurethane material, but also to find a methodology which could be applied to different polyurethane systems with different nanoadditives. From this point of view, this work presents a collection of characterization techniques, both experimental and theoretical, that can clearly help to reach this objective. 
Furthermore, it is necessary to mention that this work has helped to a better understanding of rigid polyurethane foams-nanoclays system, and also has supposed the starting-point of a new research topic in CellMat Laboratory. Beyond the results, this study has set a collection of procedures for future studies, starting with a better understanding of the different dispersion techniques and ending with a complete modelling of the thermal conductivity.

This work has also generated knowledge that has been employed in several projects with private partners:

- Project 1: Polyurethane foams for surfboards manufacture, funded by Foam Asturblank (2009-2010). The knowledge acquired in the dispersion techniques was fundamental. In this project, the objective was the optimization of commercial polyurethane blends for the production of PU foams for surf boards. The recent close down of Clark Foam manufacturer, a reference in surf world, motivated to manufacture a new material with similar properties. For this aim, different commercial surf boards were studied (Clark Foam, TSF, Safari), identifying the critical properties which made the Clark Foam surfboards the surfer's favourite. With these values, different additives were introduced in a polyurethane formulation for surf boards to adapt the physical properties to the demanding requirements of this application. Foamed polyurethane materials containing different type of fillers were produced, both at lab scale and industrial scale. The materials were produced and characterised using the techniques set-up during this $\mathrm{PhD}$ research.

- Project 2: Development of novel polyurethane foams with improved thermal insulation, Funded by Bosch and Siemens Home Appliances (BSH) Group (20122013). In this project, funded by the German Company BSH, the aim was reducing the thermal conductivity of the rigid polyurethane foam used in the production of fridges. The knowledge acquired during this $\mathrm{PhD}$ thesis about the effect of particles in the thermal conductivity of polyurethane foams, together with the experimental studies (extinction coefficient) and the modelling of thermal conductivity, allowed obtaining a 4-5\% reduction of the thermal conductivity for this specific rigid polyurethane foam. Therefore, a better performance and lower energy consumption of commercial fridges was reached. 
- Project 3: Use of sepiolite nanoparticles to optimize the structure and properties of PS and PU based foams, funded by the major producer of sepiolites in Europe, TOLSA S.A. (2012-2013). In this project, the effect of ???? sepiolites, a kind of nanoclays with fibrous morphology, on the structure and properties of rigid polyurethane foams was studied. For this purpose the production and characterisation methods developed in this research work were employed.

\section{FUTURE WORK}

After the work performed, several interesting research topics will be the focus of CellMat in the following years. Here we summarize some of our ideas:

1. Performing a similar study but with a more appropriate selection of the raw materials. Taking into account the conclusions of this thesis a better selection of the polyurethane system and the clay functionalization can be done in order to obtain better improvement in this kind of materials with the help of nanotechnology:

> The selection of a polyurethane blend formulation with less dependence of their mechanical properties on the $\mathrm{H}$-bonds is highly recommended. So, a higher improvement of the mechanical properties could be obtained with the use of nanoclays.

Selection of the nanoparticles type: the use of nanoparticles with a different morphology and surface chemistry could help to obtain better results in the mechanical properties. Moreover, the nucleation effect could be maintained. Anyway, a study of other type of nanoparticles over the extinction coefficient could be desirable, as the aspect ratio of the particles could play an important role in this mechanism.

2. Establishing a methodology to analyse the kinetics of both the blowing and gelling reactions. This methodology should combine experimental techniques such as FTIR, thermography, $x$-ray radioscopy and optical expandometry. The key concept would be to acquire a better understanding of the effect of the particles during the foaming process. 
3. To clarify several aspects of the modelling of thermal conductivity. In particular the change of the optical properties of the base polymer and the effect of clays presence on the thermal conductivity of the solid phase.

4. To develop procedures that could produce a better dispersion and a better exfoliation of the nanoparticles. 